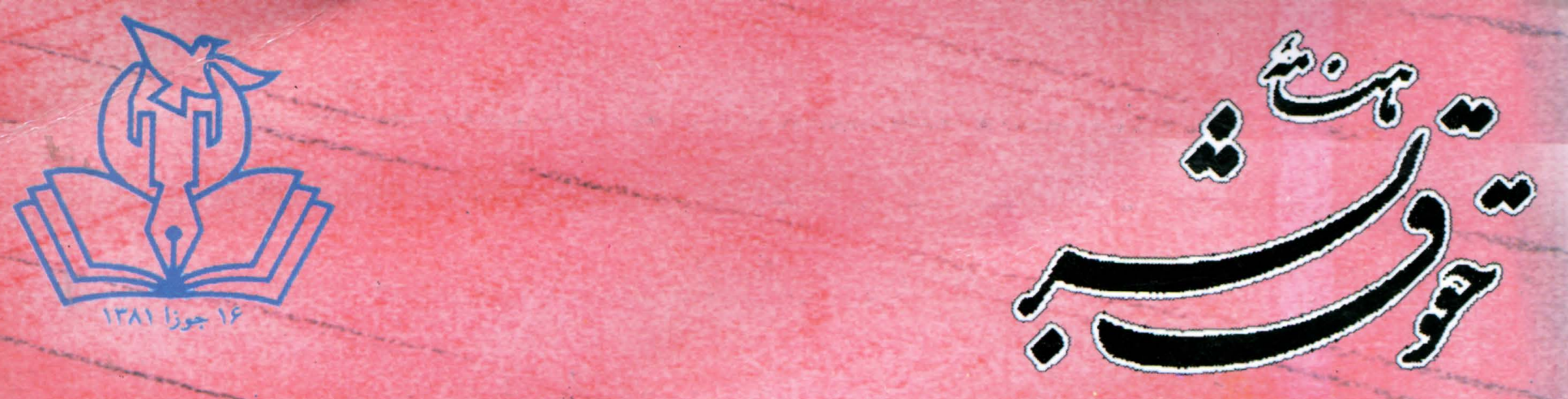

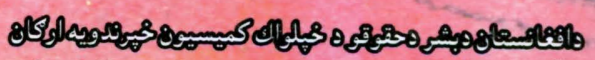
శี

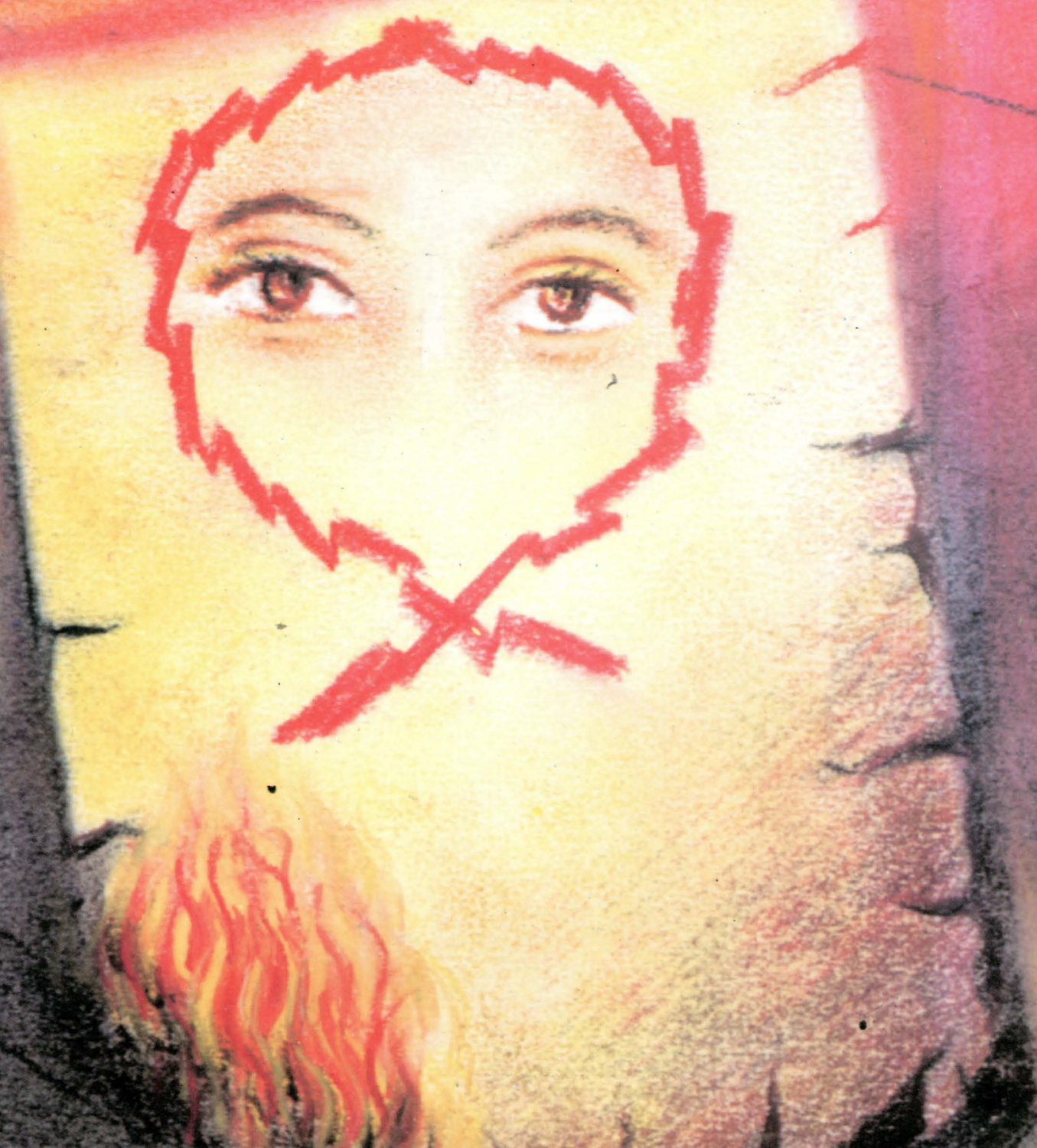
$x^{2}$ a.

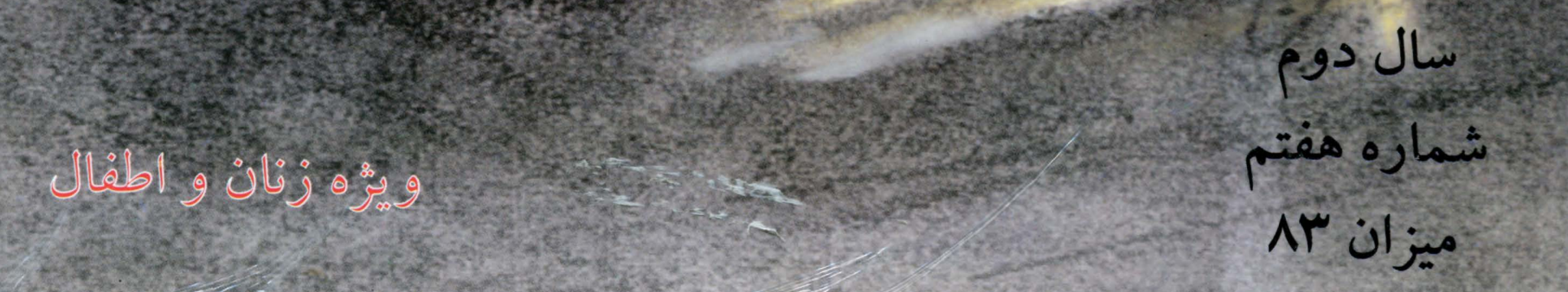
eg ju

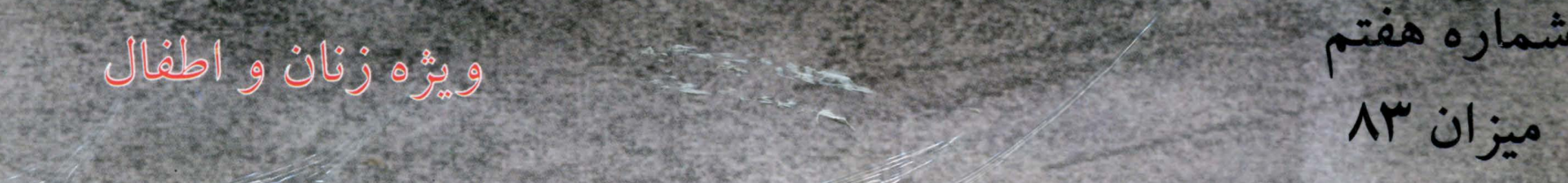




\section{د نبنحوشتحرة}

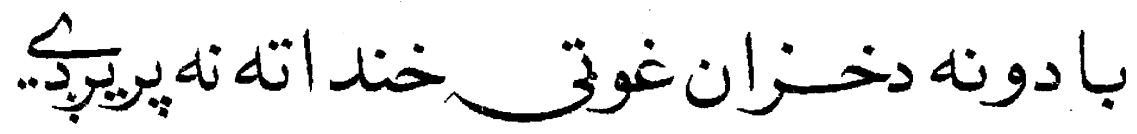

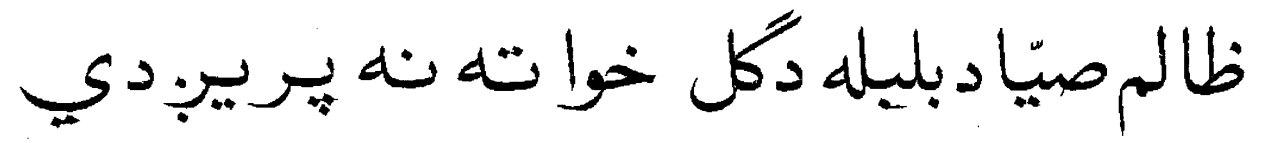

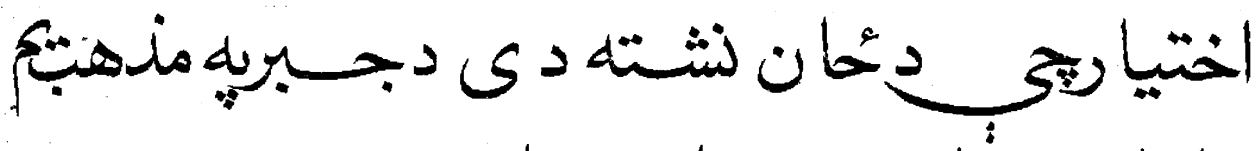

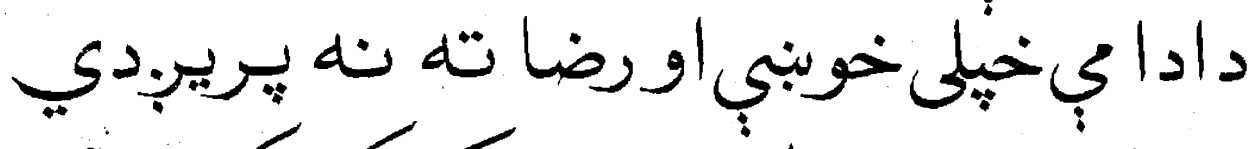

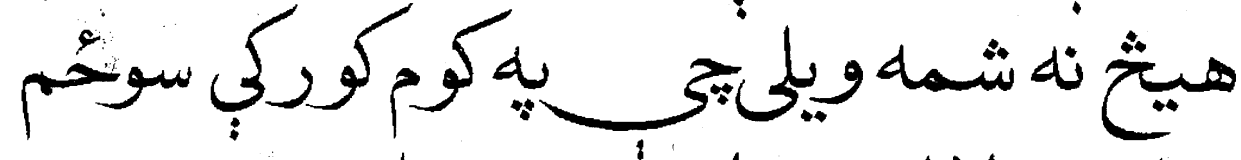

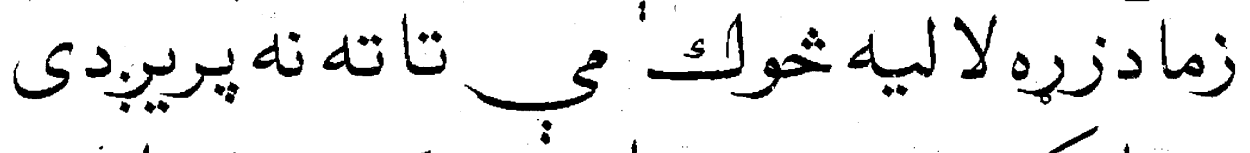

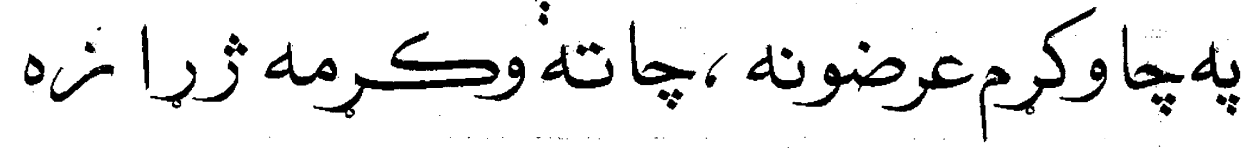

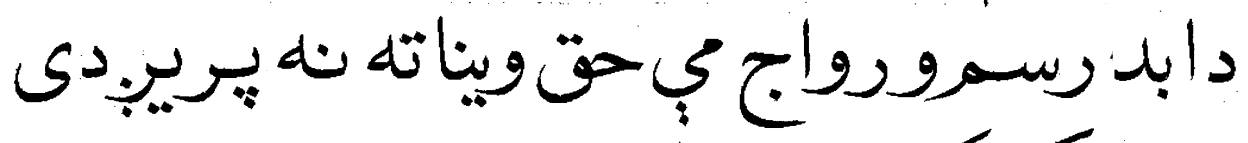

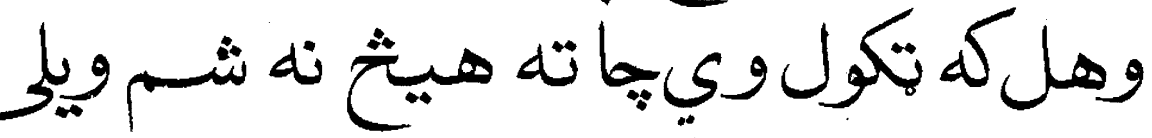

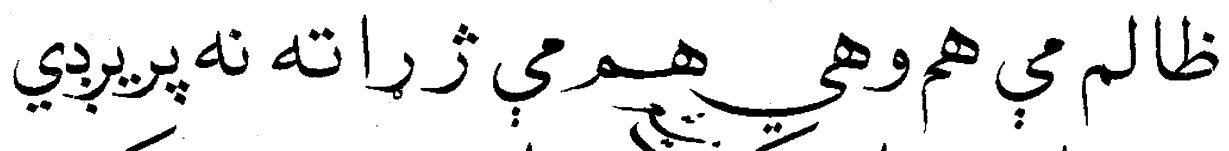

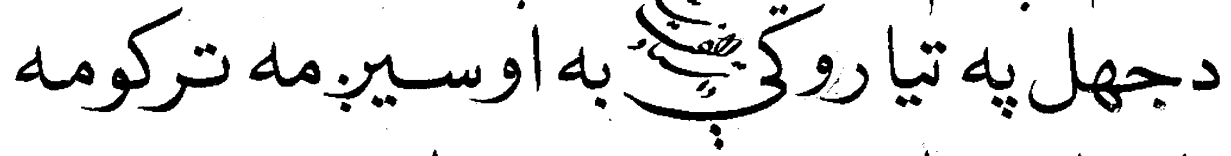

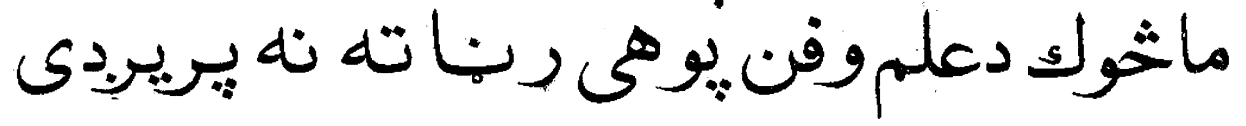

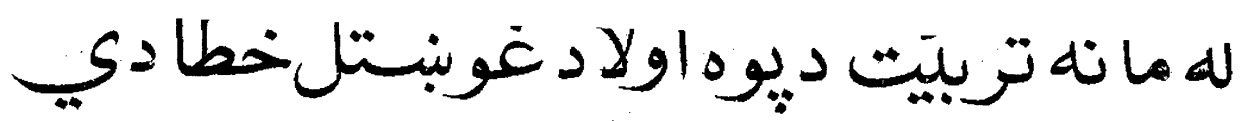

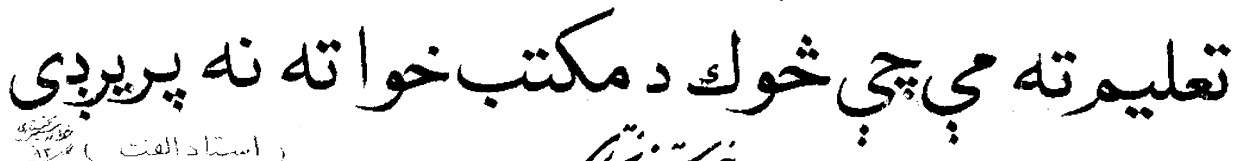

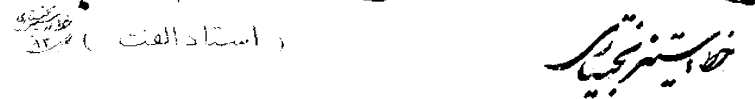




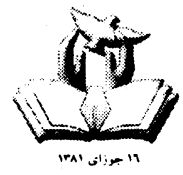

"فهرست

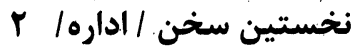

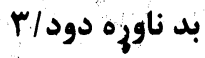

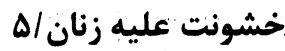

كوجني به كوجني جسم كي لوى شخصيت دى /

سن ازدواج در قانون اساسى/.

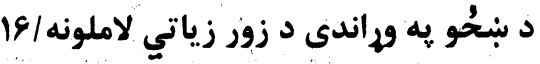

حقوق زنان در اسلام و فرهن؟ افغانى/19

اين راه كه ميرويم به ناكجا آباد است/Iان

زور زياتى د نارينو حق نه دى/rrr

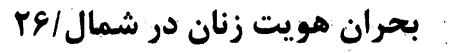

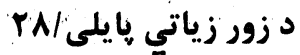

حقوق دختران بر والدين و.../×

دقانون زور به د زور ير قانون لاسبرى شي/F

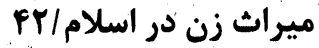

د آغلى داكتر سيما سمر يه هكله د باول شير جايزى/Fq

زنان در معرض خشونت/ها

خشونت خانوادكى /

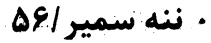

كنوانسيون حقوق طفل به زبان ساده/هوه

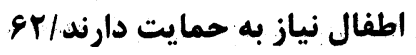

اخبار و كزارش/و

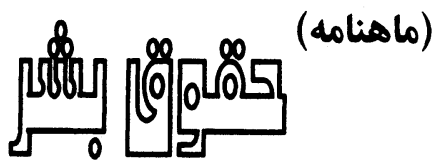

د افغانستان د بشر دحقوقو دخهلواك كميسيون خهرندويه اركان اركان نشراتى كميسيون مستقل حقوق بشر افغانست دمبان

جوهندوى معمديونس طلغيان ساكايى

مشايد مسלول:

نور مراد

הagivis

عباس Tرمان

الdيوتمود

حاتمى

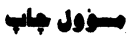

مطبعه بير

קויד:

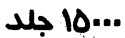

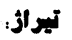

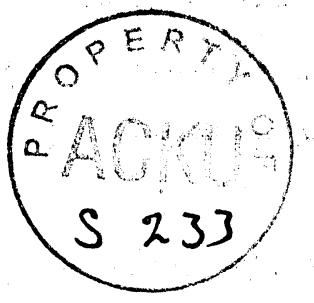

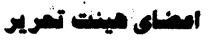

ثريا احمديار

محمد فريد حميدى

حميرا نعمتى

ضياء لنكرى

تمست نسار: 'شيخ على احمد فكور

آدرس: كارته سه، بل سرخ، كابل - افغانستان (.r.) rA.. IQY

تيلفون:

www.aihrc.org.af

صفحه انترنت :

E-mail:aihre@aihrc.org.af

ايميل: - n

Tرس دلاتر ساحوى كميسيون مستعل هلوق بشر

مزار شريف- عقب شهردارى، نزديك مسجد خيرخواه

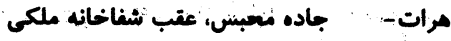

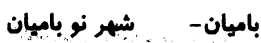

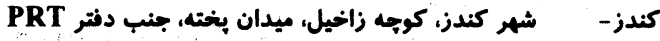

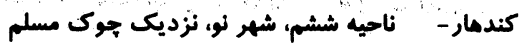

كرديز- عمارت رياست زراعت

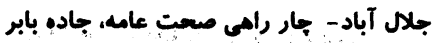

بدخشلن- شهر فيض آباد، شهر نو

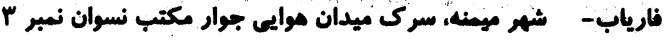

ل خ خطاط، محمد جاويدان

اين مجله به گونه رايگًان توزيع مىشود 


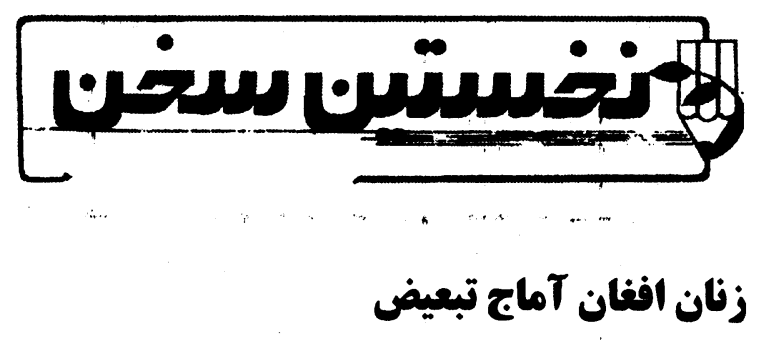

اكر خواسته باشيم تبعيضات عليه زنان را در افغانستان حساب كنيم، فهرست مطولى از انواع تبعيض ها را به دست مى Tوريم. ما هرروز با كونه هايى از اين بديده مواجه هستيم كه به صورت هميشكى در حق زنان اعمال مى شود. برخى از اين تبعيضات بسيار تكاندهنده است؛ به حدى كه زن را از همه ى حقوق انسانى اش معروم مى مي كند؛ مثلا حق تصميم كيرى درباره ى سرنوشت كه اكثريت مطلق زنان از T ان محروم اند و مسلما كه اكثريت مطلق مردان تبعيض روا مى دارند. اين تبعيض در افغانستان به يكـ امر معمولى و غيرقابل سؤال تبديل شده است كه مداخله در آن كناه شمرده مى شود؛ زيرا زن ناموس مرد و حرف زدن درباره ناموس او غيرقابل تحمل است. زنان نيز به بسيارى از اين تبعيضات تن در داده و صبورانه اين همه بيداد را تحمل مى كنند. اين وضعيد از كجا ناشى شده است؛ جرا در افغانستان در مورد زنان اين همه بيعيض روا داشته مى شود؟ هر دليل ديكرى كه وجود داشته باشد به كمان من بزركترين و مهمترين عامل Tان عقب ماندكى كشور ماست. افغانستان از جمله جند كشور عقب مانده ترين به حساب مى رود و تبعيض عليه زنان مانند: فقر و بيسوادى و جهل از ملزومات عقب ماندكى به شمار مى رود. بس رفع تبعيض عليه زنان با تدوير جند مجلس و اتخاذ هيد تصميم عاجل اعمال شده نمى تواند. اين مسئله بيشتر به ارتقاء و بيشرفت عمومى كشور بسته است؛ مثلا اتر دولت بتواند در كل كشور برق توزيع كند و تلويزيون هاى دولتى و غيردولتى در اين راستا به تبليغات وسيع و موثر بيردازند؛ راه يك قرن در يك سال ييموده خواهد شد. در غير TT انكشاف در شهرها و عقب ماند دى در دهات باز هم تضاد ميان شهر و ده را بزركتر خواهد ساخت؛ جنانكه تجربه كرديم دهاتيان با كينه و نفرت نسبت به شهرنشينان خواهد ديد و با هرجه مظهر تمدن است، دشمنى خواهند ورزيد. بايد در رفع تبعيض عليه زنان از تعاليم دين اسلام استفاده كرد؛ زيرا اين كوبنده ترين و موثرترين وسيله در زدودن اين بديده خواهد بود. زيرا تبعيض عليه زنان با رسوم و عنعنات مردم و جنانكه اشاره شده با ننك و غيره

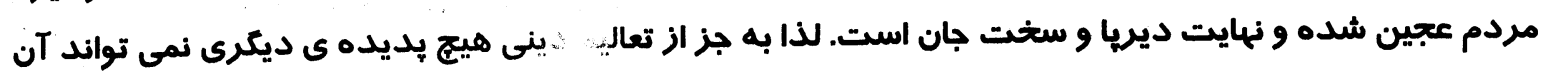
را مضمعل و از صفحه ذهن و روان مردم بزدايد. 


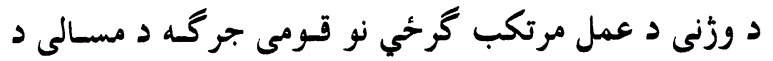

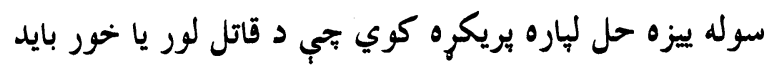

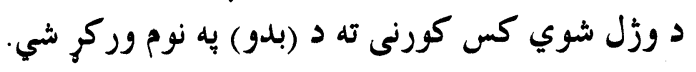

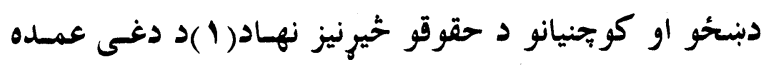

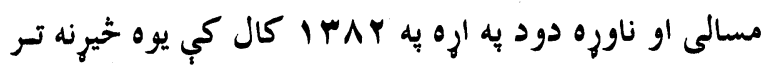

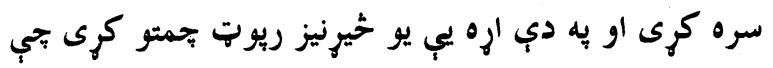

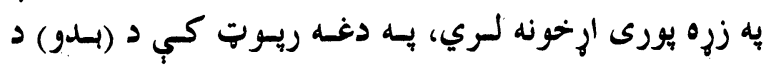
مسالى به هكله يادونه شوى ده: ((نه يوازى د ورزنو يسه خيه يهير

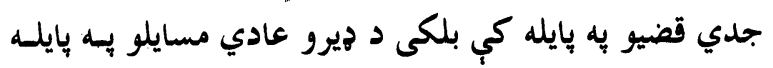

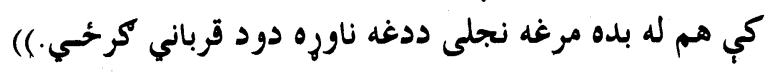
يه دغه ريوت كي د شفاهى معلوماتو له مخحى دا تبكى روبنمانه

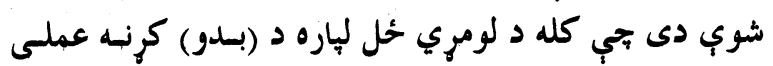

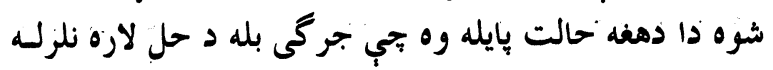

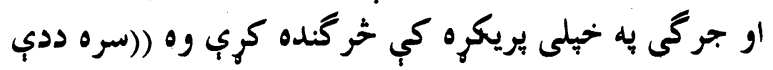

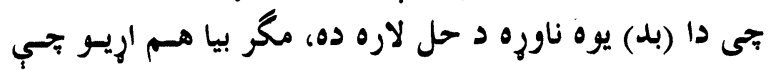

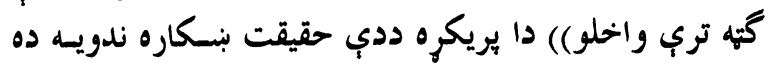

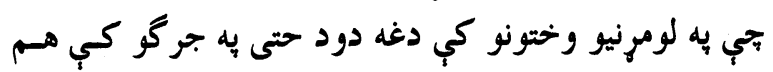

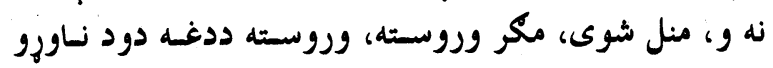

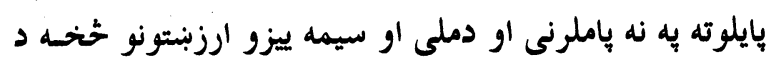

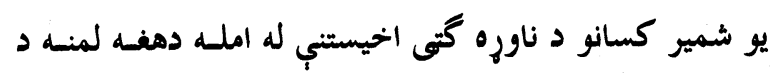
هيواد به تولو سيمو كي خوره شوه

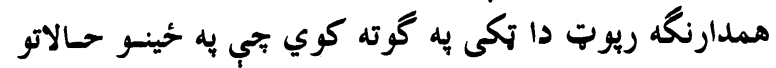

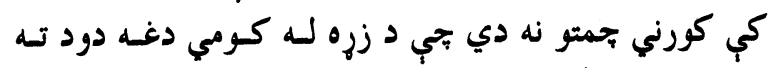

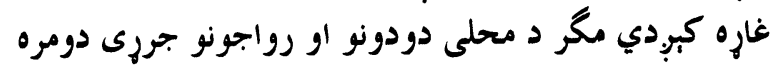

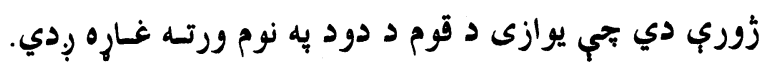

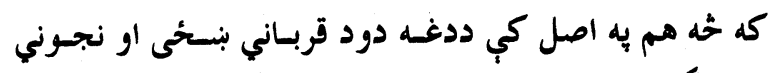

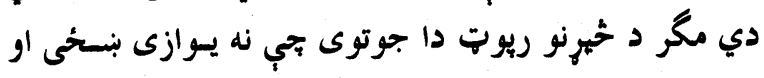
نجسونى ددي عمسل يسا كرنسى قربساني دي بلكسي نارينسه او

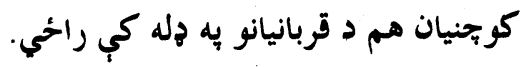

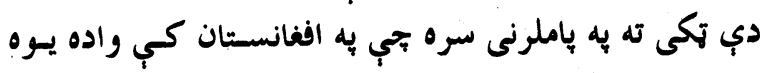

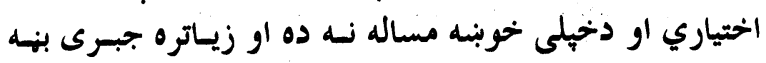
لري نوخيكه يه (بدو) كي د نجونو وركره د اجبارى واده بـهـ

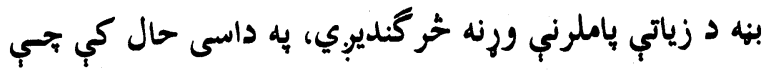

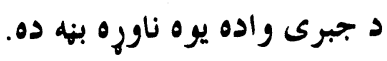

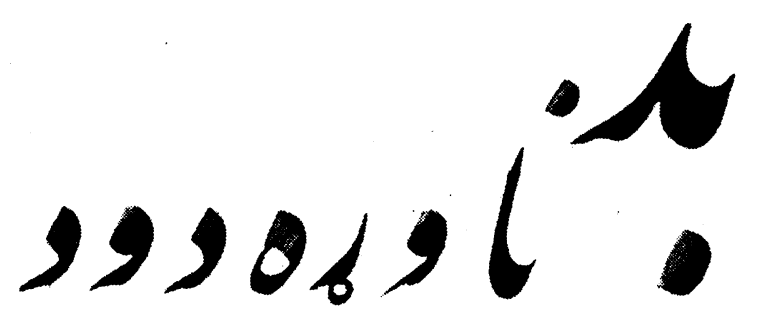

ل م-يرتم

هره تولنه يو لر حانكري محلى او سيمه ييز دود او رواجونسه

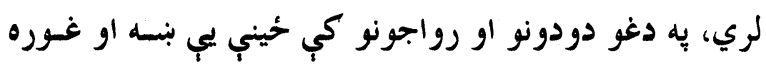

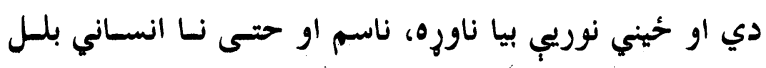
كيداب شي. زموجٍ يه تولنه كي هم يو له داسى دودونسه او رواجونسه شسته

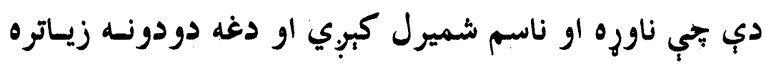

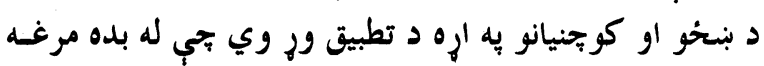

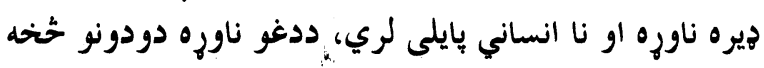

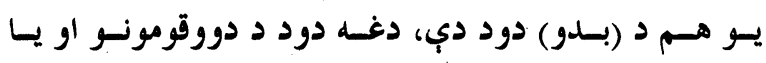

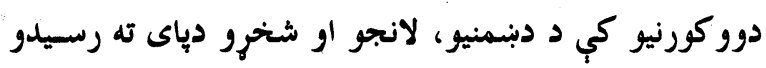

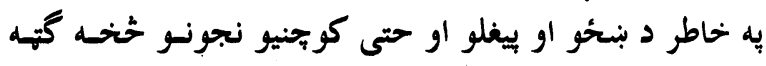

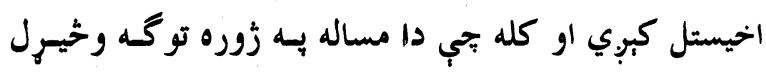

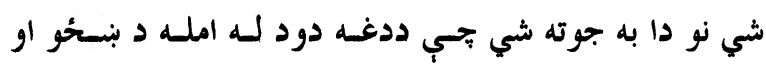
كوجنيانو سره لكه يو مريى تحلند كبوبي.

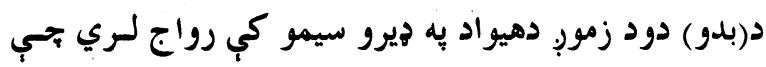
دمماغه سيمو د محلي او قومي جرگو له لاري د تطبيسق بنهـ دوريه

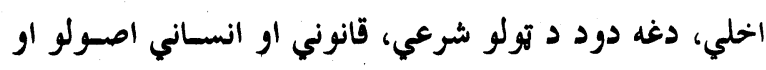

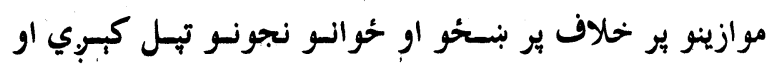
هغوي ديوه ناوره دود قرباني گرخحي.

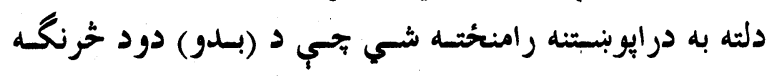

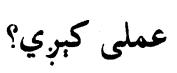

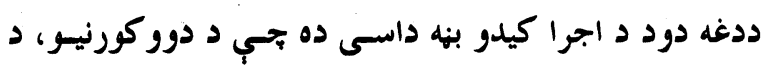

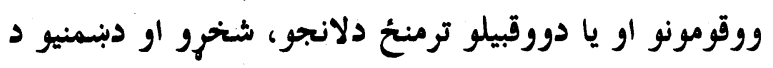

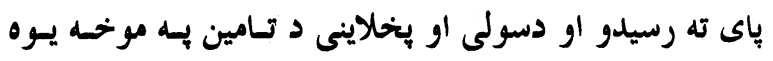

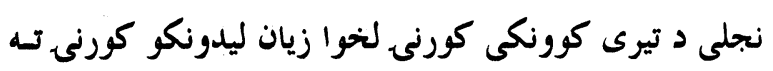
سبارل كيوي، د بيلكى به تو كه كله بجي يو بـلار او يسا ورور 
برسيره به بورتنيو دوو لاملونو نور داسسى واره لاملونسه شسته

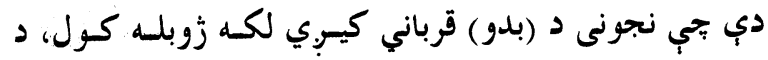

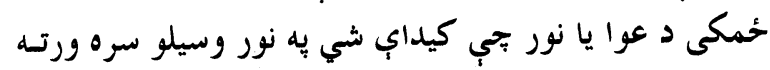

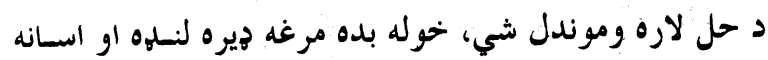
لاره يب همدا ويني بجي ديوي بنحتي او يا ييغلى زٔوند د نابيايه

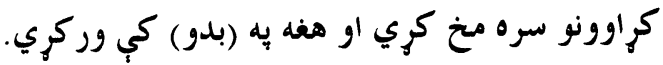

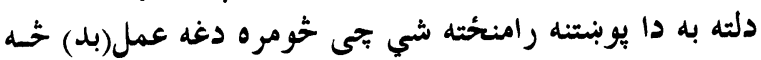
د اسلامى ارشاداتو او خه د موضوعه قوانينو له مخسي جسواز

د اسلام به سبيخخلى دين كي د بنحخي خرخول، بيرودل او يسا

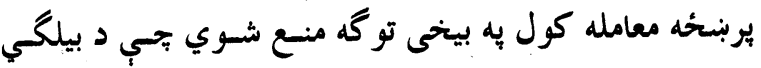

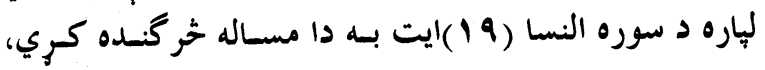

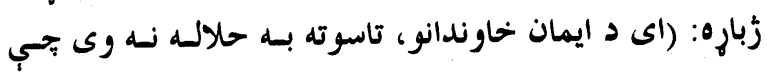

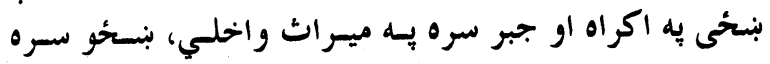

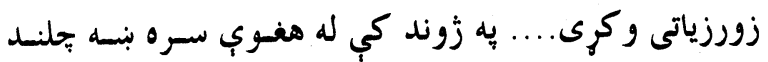

$$
\text { وكري.() زورياتي }
$$

همدارنكه خحسه بـه نريوالسو اصسولو او قوانينسو كي او حسـه د

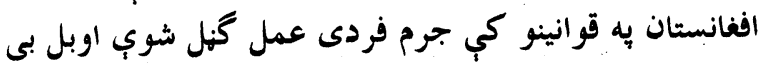

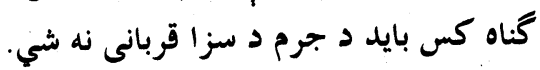

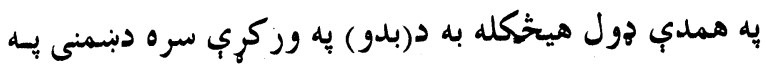

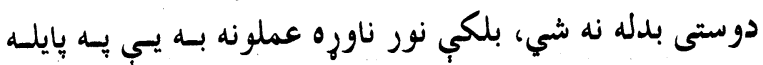

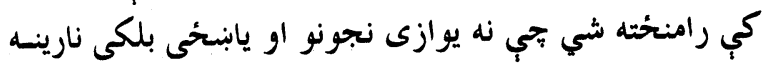

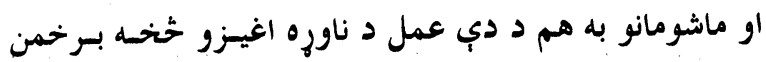
وي.د (بدو) دعمل يه اجرا سسره بسه دنسورو جرمونسو زمينسه

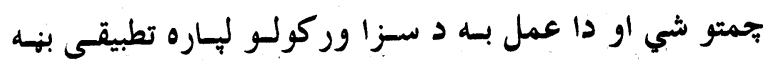

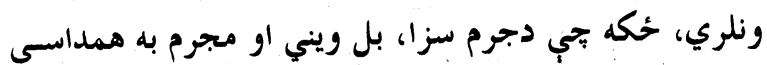
خجلو جرمونو ته دوام وركوي.

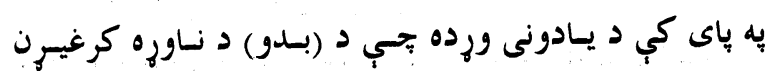

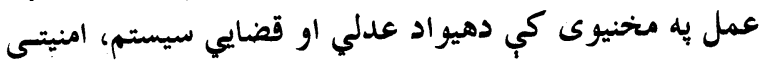

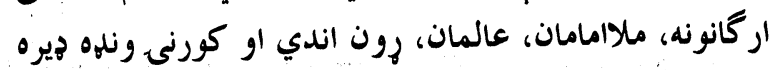

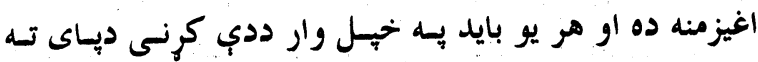

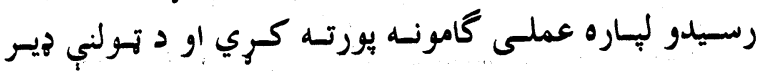
سبيخلى موجود ته جي ددي عمل قرباني گرخحي، خلاصسون وركري.
كومي قضيى ددي لامسل گرحسي جسي بنسحي او نجسونى بـه

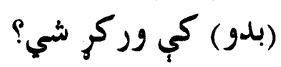

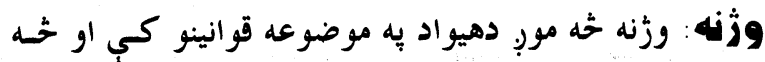

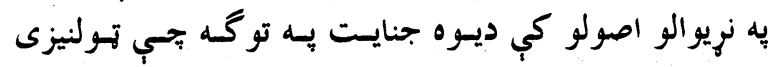

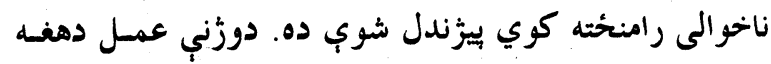

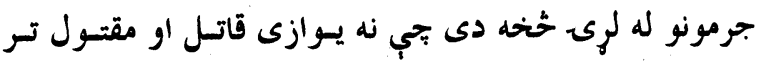

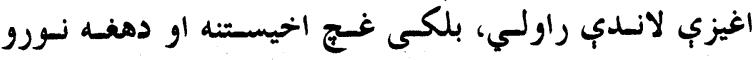
وروستنى ناوره عواقب د عمسل دواره خسواوي زيسانمن وي.

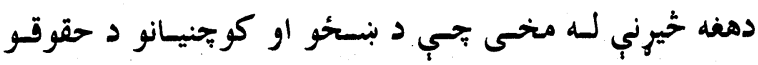

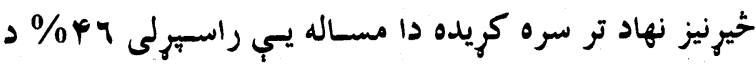
بلدو قربانيان د ممدي جنايت له امله رامنخته شوي دي.

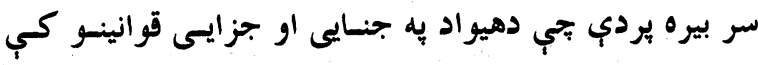

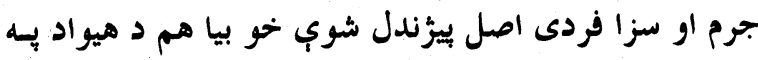

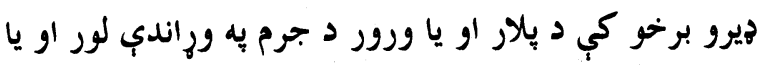

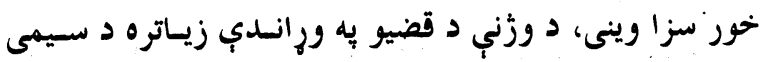

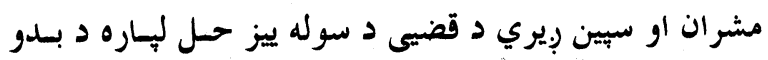

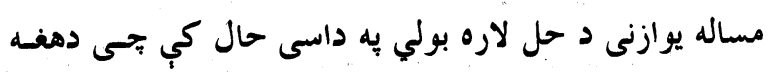
وروستى ناوره عواقب د وزّنى د عمل خخحه هم ناغوره وي.

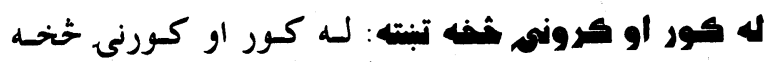

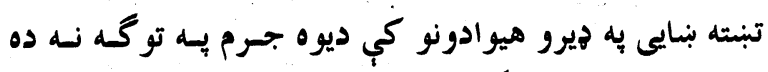

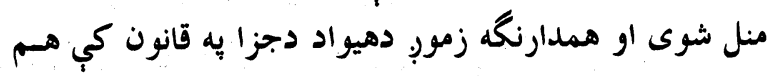

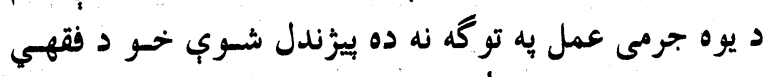

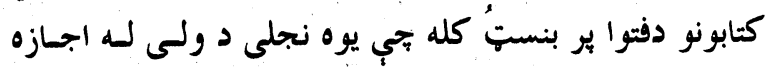

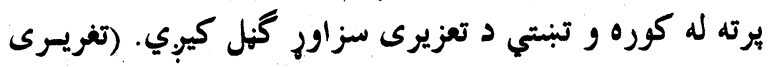

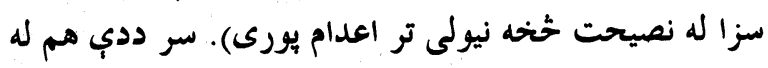

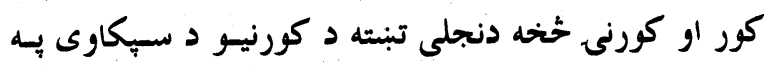

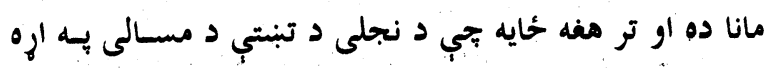

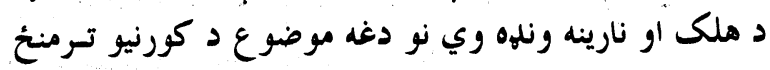

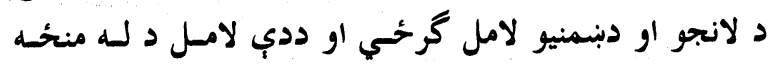

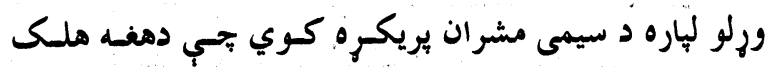

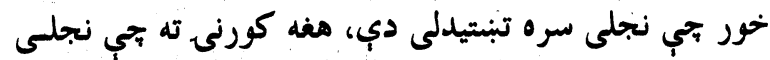

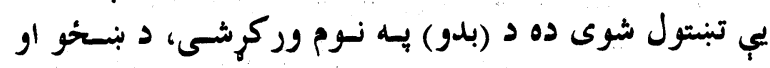

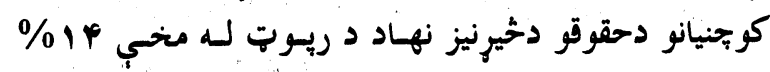
د(بلدو) قربانيان هغه نجونى دي تحى ورونه يب د نورو نجونسو دوري سره تبنتيدلي دي. 
در معرض سوء استفاده هستند. محاكم و مراجع قـانونى نيز نعاه عادلانهاى به زيان ندارند؛ در بيرون از خانه، زنان فرصتهاى كمترى رانبرابي كار در اختيار دازيند.

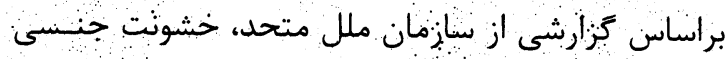
براى صدها ميليون تين از دختران و زنان، تهبيدىى جدي آن

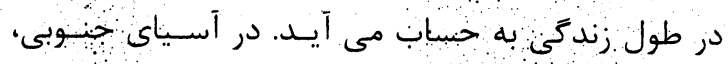

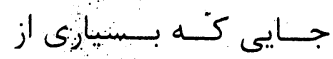

والدين هـران رانه

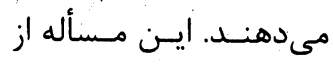
زندگَى داخل رحمى آغاز

$$
\text { مىشود. }
$$

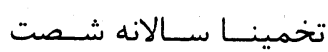

ميليون دختـر در نتيجـه

سـقط جنـين (بـه دليـل

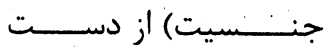

مىروند. از هـر جهـار زن يكىى در طــول حـاملغَى مورد سوء اسـتفاده قـرار مى خيـرد. سـوء اسـتفاده خانكَى، خــشونت مربـوط به جهيزيه، ختنسه زنسان،

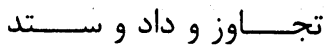

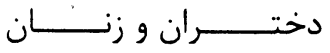
صورتهاى ديخر اين مسسأله هـستـند. در بخــشهـيـى از

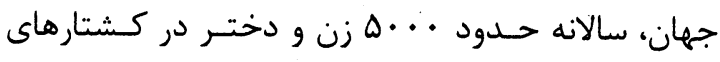
ناموسى به هلاكت مى رسند كه اغلب به دليـل رسـوايى ناشى از قربانى تجاوز بودن است. هر سال دوميليون تـن

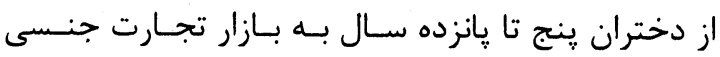
معرفى مىشوند. تخمينا جهـار ميليـون دختـر و زن در در درن

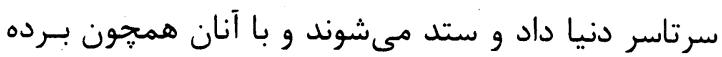

$$
\text { رفتار مىشود. }
$$

口
زوايات بسيارى از مقام زن و جايخاه فردى و اجتماعى او، در تمامنى إيان، نسل به نسل و سينه به سينة نقل شده اسبت؛ ولى با نغاهى به حذششته مسى بينــيم كـه در كنـار

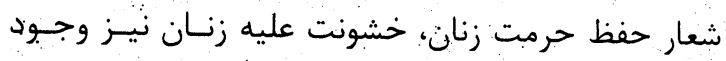

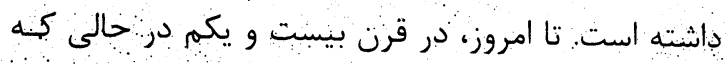
ادعاى حفظ حقوق بشر گوش فلك راكر منى كند، هنوز
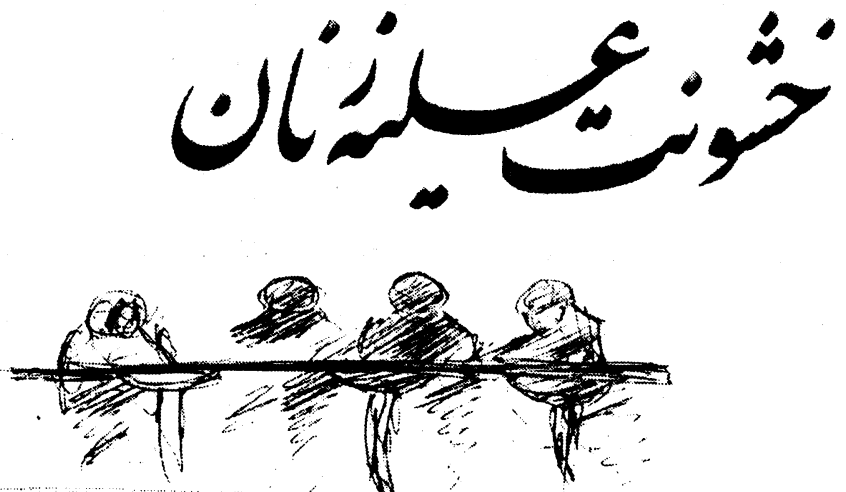

شاهد بى رحمانه ترين خشونتها عليه زنان هستيم. خشونت طيف وسـيعى از رفتـار هـاى انسـانى را در بـر

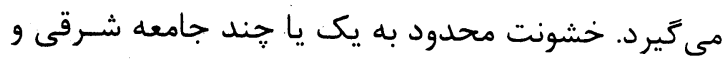
بالاخص اسلامى نيست، بلكه اين امر در جوامع غربسى و

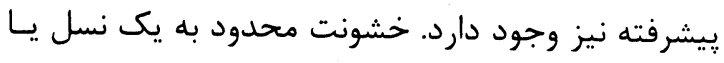
يك قرن نيست بلكه يديده ایى گسترده در طول تاريخ و در عرض جغرافيا است. در سراسر دنيا تبعيض و خشونت عليه زنسان و دختـران در فرهنگ دها ريشه دارد. زنان و دختران از دسترسى بسه

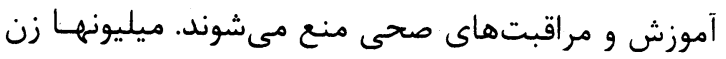


مزمن) صدمات دوران حاملغى، صدمات وارده به كودكان

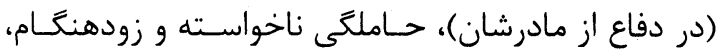
بيماريهاى مقاربتى و غيره مىشود.

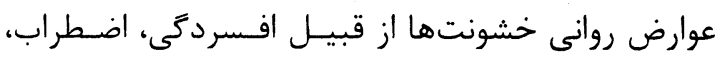
بيمارى هاى روانى، كاهش اعتمـاد بــه نفسـ، مسشكلات تغذيهاى، اختلالات جنسى و غيره مىباشد. زن در افغانستان، سمبول از رنج ـو مظلوميـت اسـت، زن ترازيدى متداوم و تاريخى كثور يرحادثه و آسيب ديـده ى ما اسـت. زن افغـان در خـانواده و اجتمـاع موقعيست ضعيف داشته و مورد خشونت قرار مسى

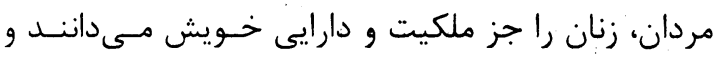

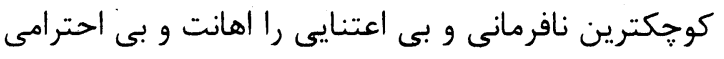
به خود تلقى نموده و در صدد انتقام بر مى آيند، كمترين

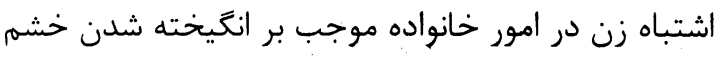
مرد گرديده باعث اعمال خشن ترين، غير انسانى تـرين، بى رحمانهترين و نارواترين رفتار و اعمال خشونت آميـز نسبت به زنان درخانواده مى گردد. كـه در كـشور مـا در طى سالهاى اخير اين خشونتها مهمترين عوامـل خــود سوزى و انتحار زنان محسوب مى گردد. همجنــان ازدواج

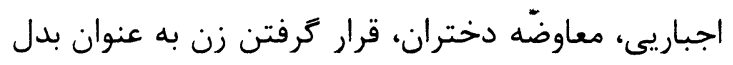

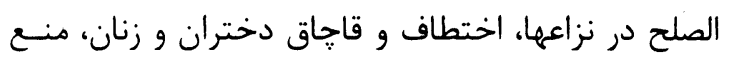
آنها از كسب تعليم و تربيه، وضع صحى ناگوار، نمونههاى بارز اين يديده است.

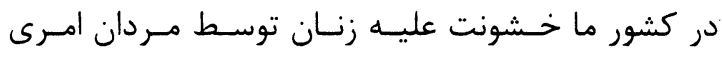
معمولى تلقى مى گردد كه حس خشونت يذيرى در بـين بعضى زنان را نيز به وجود آورد اسـت. تعـدادى از زنسان خشونت را مسأله غير عادى و غير طبيعسى نمسى داننـد و ونس لذا با رفتارهاى خشن، ساز كارى نشان مي دهند. خشونت براى برخى يديده ها موجه و قابل قبـول تسشخيص داده مىشود. براى تربيت كودكان و حفظ انسسجام خـانواده و ي يـشخيرى از انحرافـات و كجرفتاريهـا، خـشونت مجساز تشخيص داده شده است. بعضا توجيه خشونت عليه زنان با تكيه بر طبيعت برتر مرد و با لستناد به متون فقهل و مذهبى صورت مى كيرد.
ييمان نامه رفع خشونت عليه زنـان كـه در سـال ب199

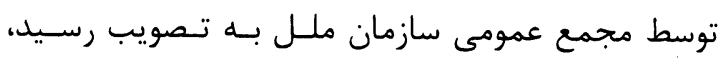

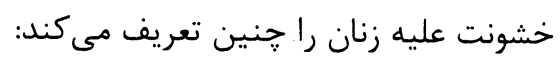

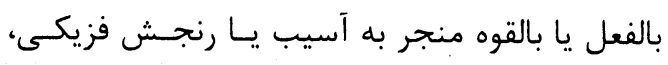

$$
\text { جنسى و يا روانى آنان شود. }
$$

تهديد به اعمال خشونت آميز كه سلب اختيـار و يـا رونيا

$$
\text { محروميت اجبارى از آزادى محسوب خردد. }
$$

در زندگى عمومى يـا در زنـدگى خـص موصى صـورت

$$
\text { گيرد. }
$$

خشونت داراى اقسام مختلف اسـت كـهـ برحسـب شـيوه

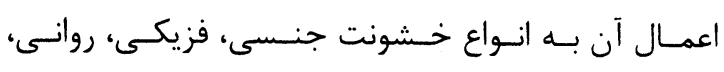
احساسى و اقتصادى تقسيم بندى مى

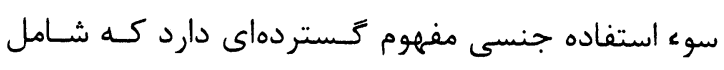
اجبار جنسى (اعم از احسـاسى، فزيكىى و يـا اقتصادى) معزى عليه زنان است. سوء استفاده منحصر به تجاوز نيسست و

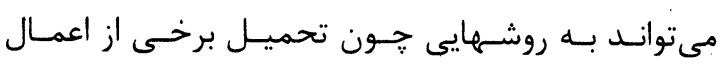

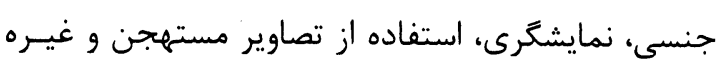

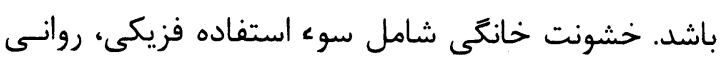

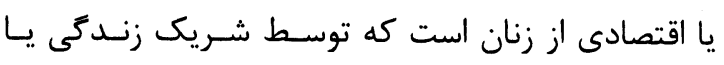

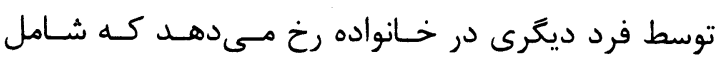
موارد ذيل است: خشونت فزيكىى مثـل لـت و كـوب، بريـدن اعضـاء،

$$
\text { سوزاندن، حبس كردن در خانه و غيره. }
$$

خـشونت احسـاسى و روانسى كـه طيـف وسـيعى از

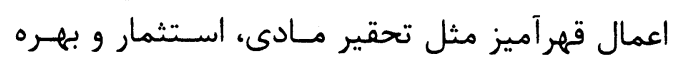
بردارى، تحقير روانى، فحاشى، محروميت از آزادى و حقوق و غيره را شامل مىشود. خشونت اقتصادى: مثل تصرف در دستمزد زنان بـهـ طورى كه مرد كنترل كامل در آمـد خـانواده را بـه عهده داشته باشد.

تعميل خشونتهاى متذكره باعـث عـوارض جـسمانى و

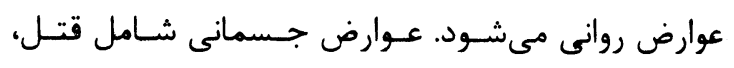

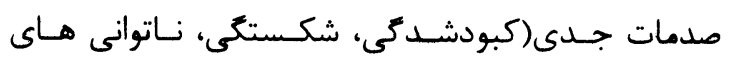


و در مراحل ابتدايى آموزش رسـمى و مراحـل ويـشرفته

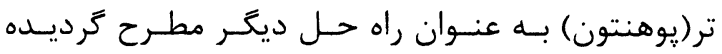
مى مواند. همان طورى كه مى دانيهم اغلب موارد خشونت عليه زنسان

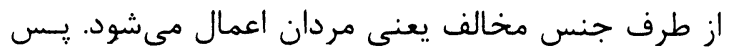

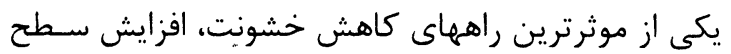

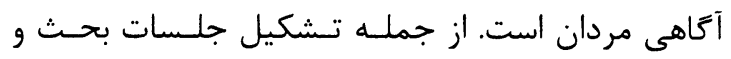

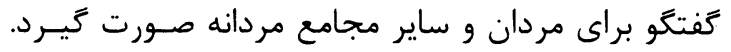

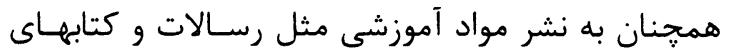

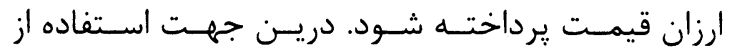

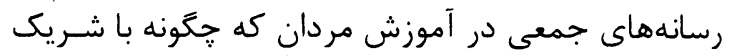

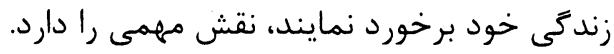

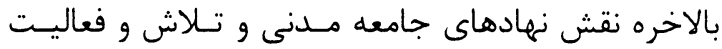

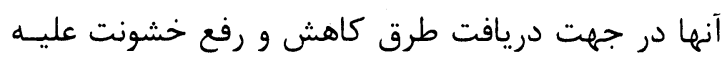
زنان نيز درخور اهميت فراوان است دري

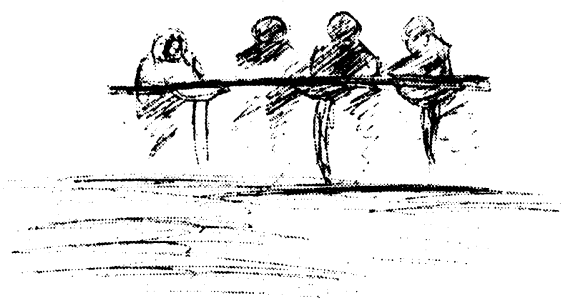

زنان اكثرا خشونت خانكى را ينهان مى كنند و به آسـانى

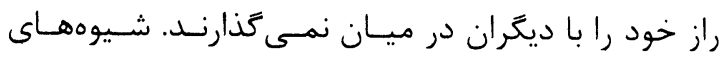

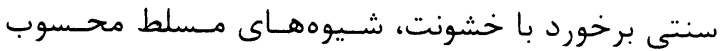

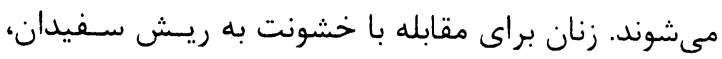

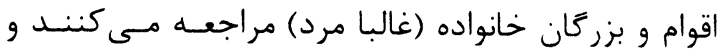

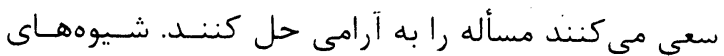

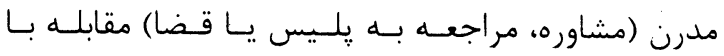

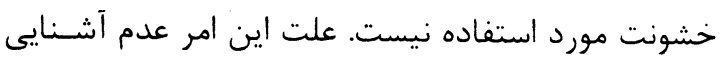

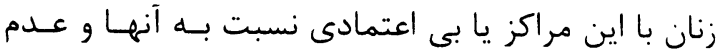
كار آيى آنهاست. ناسن مراكن براى حذف خشونت از زندكى زنان، راههاى بسيارى بايد

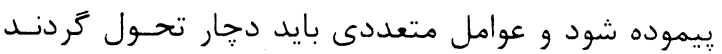

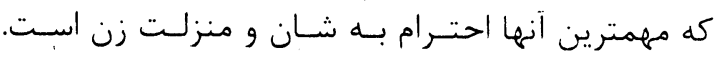
حكومت نيز در تامين عدالت جنسى داراى نقش كليدى

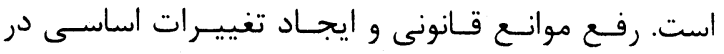
قوانين، سياستها و برنامه ها، كامهـاى مهمى هـ هـتئند.

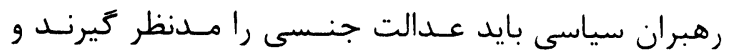

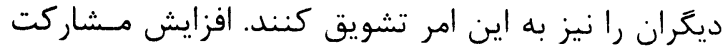

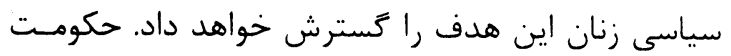

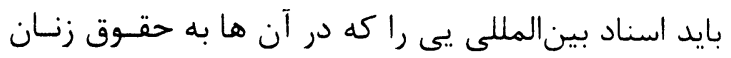

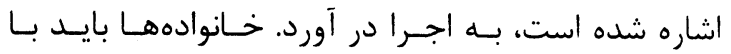

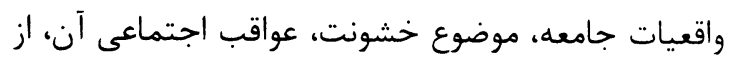

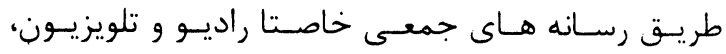

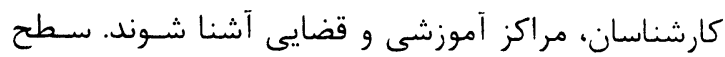

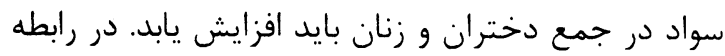

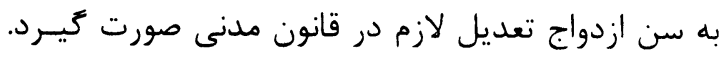

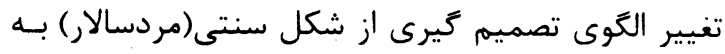

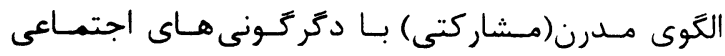

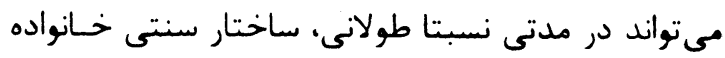
ا أحت تأثير قرار دمد. آموزش لازم درباره يیشخيرى از خشونت و نحسوه دهوه رفتـار

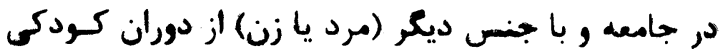


لري، كه جيرى دكو جحنى همدغه دوره يه ليك، لوسست

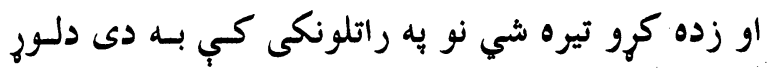

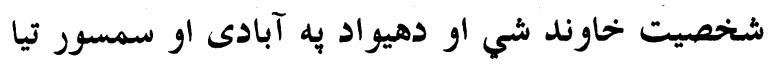
كي به لوى مرسستندوى وي، راتلـونكى بـه نسوى نسـل يورى اره لوي او نسوى نسسل د كوهنيتسوب خخحسه ييسل كيوي. د كويجنيانو د سايكولوزي له يلسوه دِ كـويحنى د روزنسى محيط د ده دراتلونكى تاكونكى دى، يعنى:

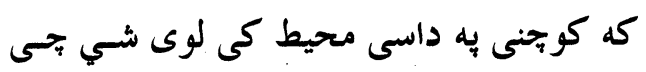

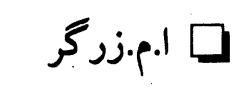

برده باندب ذيرى نيو كى(انتقادونه) كيوي نو هرو مرو به دا كوجنى داسى لوى شي تحى زٔر زُر به نور محكوموي.

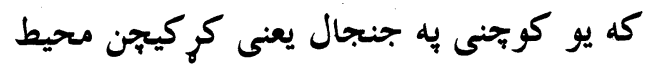

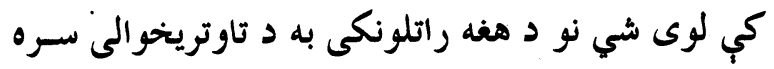

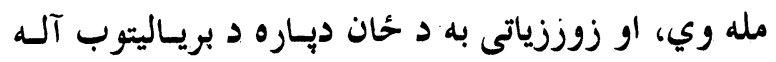
كرحوي.

كه ديوه كوجني د روزني محيط ملنسهى وهـل $\checkmark$

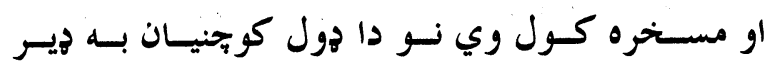
شرمندى او گوبنه خوبنسونكى لوى شي.

• كه يو كوجنى به داسى محيط كي لسوي شي جهـي بايسـد محجسوب او شــرمندك وي، نسو دا زول
انسـانان د نسورو زونسدى زوو جشــان د زونسـد مرحلـه د

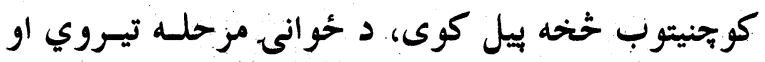
بيا د زوند د يوخوالى دوره راحئي او يهِ يايى كي انسانان

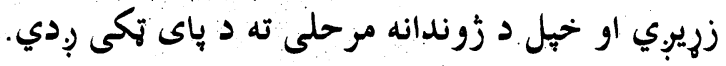

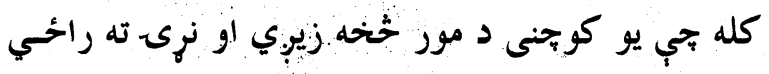

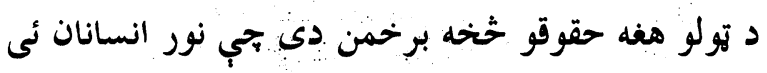
لري، د مور او يلار مينه او روزنه ددى حسق دى، دغسه

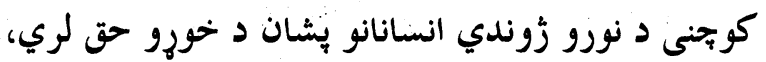

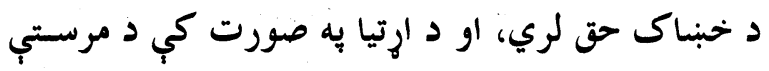
حق لري. د نسرى تهول

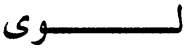
لاربنــــورنكى او فيلسسـوفان د ســـــقراط خخسـه نيسولى تو ارسطو او

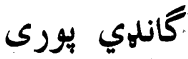

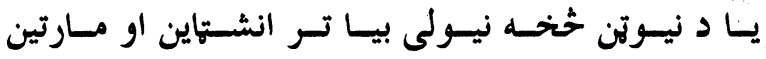

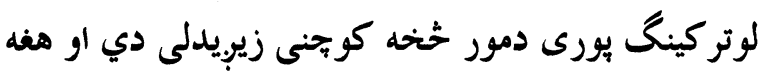
مرحلي يي تيرى كريدي كوم تي موبِ مخته ورته اشاره

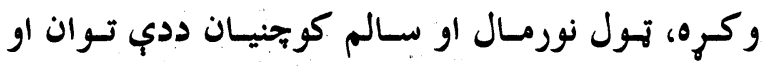

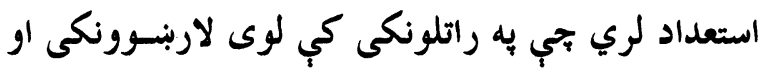
يوهان شي خو دهغه شرط دادى تجى به سم محيط كي

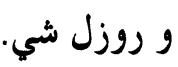
كو جنى هغه گل دى جي به تولنه يورى تولى دى او هـر كوجنى يو لويانو حق لري اجي دده مرستندوى شي، هغه

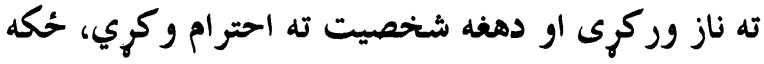
د كوجنى روزنه دده يـر راتلسونكى بانسدي اثـر اجسـوى، كوجنيان به كوجنيتوب كي د زده كـرو زئسر اسـتعداد 
حئايونه ورته تياروي، نو دا شيان هغه وخت امكان لـري جــي د كورنيسو د كوجينـانو شـمير لـوبِ وي او ددوى اقتصادي وضعه بنه وي، كه ديسوي خــوا خخخسه د دوى كوجينان دومره هيروي نجي دوى يب د خورو او جـامو خخه وتلاى نشي او اقتصادى وضعه يسي ورخٔ يسه ورخً

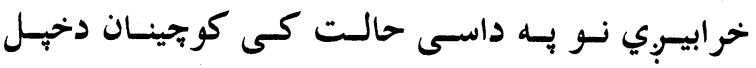
كوجنيتوب خخخسه خونسل نشسى اخيستستلاى، بـه روانسى (سايكولوزيكى) لحاظ هغوى زره خــورين، متعصسب او غع اخيستونكى لوييبِى بحي دا يو دير لوى ظلم دى، دلته جي بـه كليسو والـو سـيموكي لرغونسو دودونسو او رواجونو تقريبا د قانون شكل نيولى دى نو ديسره سـخته ده جي داستونزه زر حل كرل شي، كله بهى د داسىى

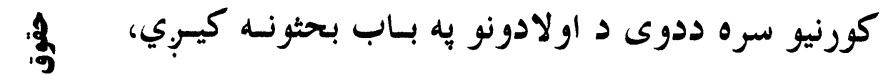
جي كوجنيان بايد دومره شمير ولري تجي مسور او يسار 3 دهغه د روزنى او خورو خخه ووزى، كه كوجنيـان بسى روزني او بي مسئوليته لوى كرل شي، نه دا بحى د مـور او يلار زٔوندور تريخوى بلكى د تولني د بلدمرغى سـبب كيداى شي، بس علم، يوهل او روزنه هغه حت دى، بتي اولاد يب هيرمور او يلار او بيـا يـر محسيط بانسدي لـري،

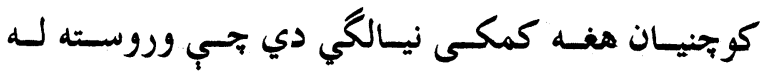
خُومودى به لويو ونو بدليبوي او تر ديسرو كلونسو يسورى ميوه وركوي.

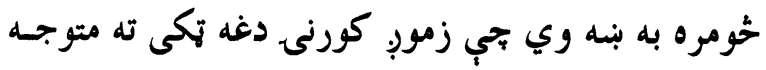
شي، تجي كوجنيـان هفسه سـتر شخصسيتونه دي بهي بـه

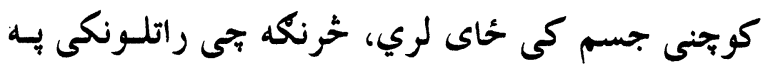
دوى يورى اره لري نو دا لازم دي، تجي هر كوجنى تسه خاصه باملرنه و كرو او دغه نيالكى يه ثمر لرونكي ونسي

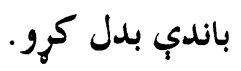

كوجنيان به تل خحانونسه ملامـت او گناهكساره احسـاس كري. كه د يوه كوجنى د روزنسي محسيط داسى وي

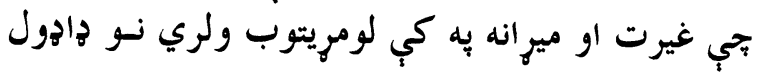
كو بحنى به تل يرخان ويسا او باوري وي.

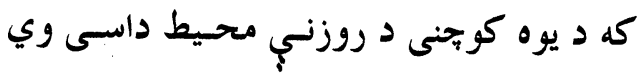

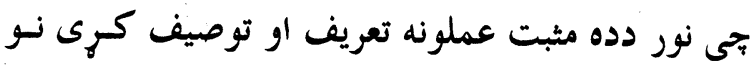

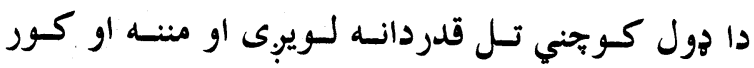
ودانى زده كوي.

كه يو كوتخنى به عادل محسيط كي لويرئ او

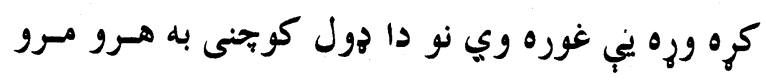

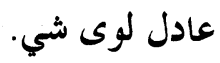
كه يو كو جنى به سوله او امن كي وروزل شي إيكاني نو هغه به تل ايمان لرونكى (ايمانداره) وي.

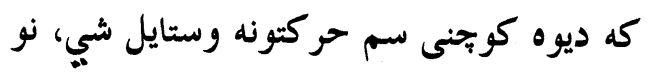
هغه به خجيل بحان ته احترام ولري. كه يو كويخى به داسى محيط كي لوى شي الهي جي هلته دوستى اوصميميت وي او دى نوروتسه گحران

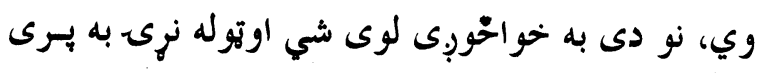

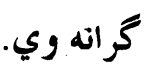
كو جنيتوب د مينى، محبت، او صسميميت دوره ده،

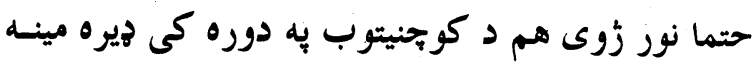

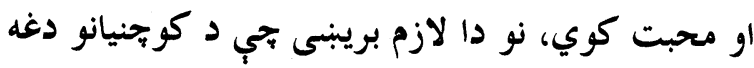

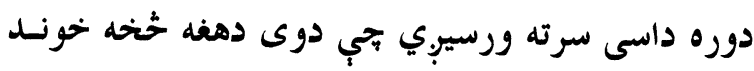

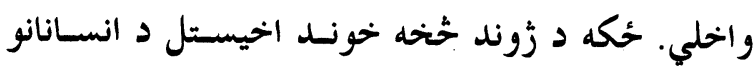

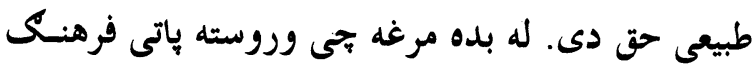

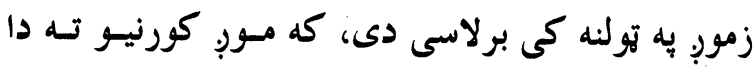

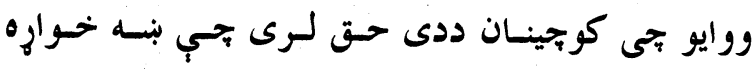

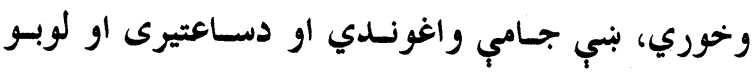




\section{ك'نיو'ج}

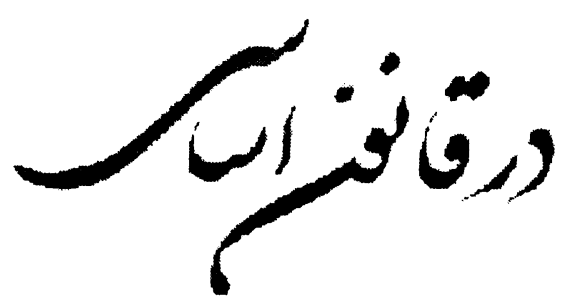

در اين نوشته، سعى خواهد شد كه سن ازدواج بررسى

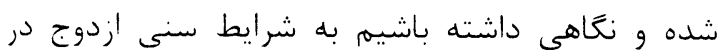

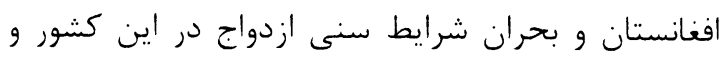
عوامل ييدايى اين بحران. مسأله:

קهد سنى براى ازدواج دختر و يسر از سوى قانونگذار

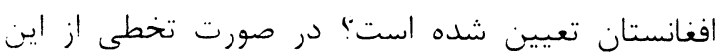

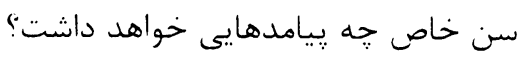

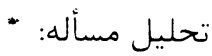

ازدواج تابع شرايط و قواعدى است. از جمله شرايطى كه

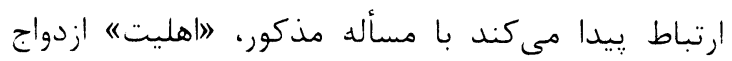

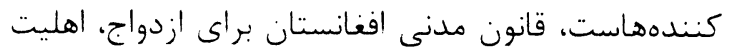

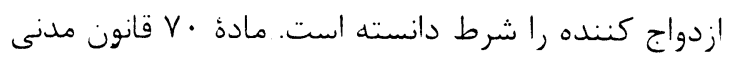

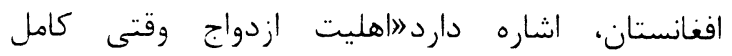

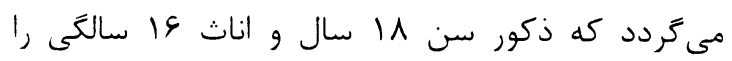

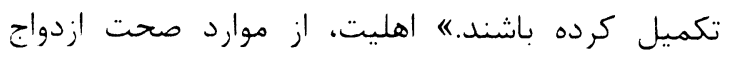

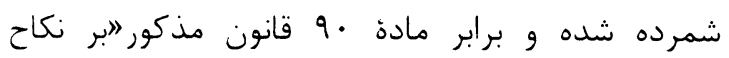

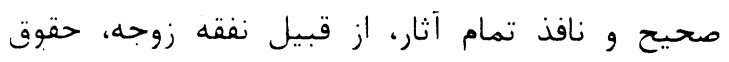

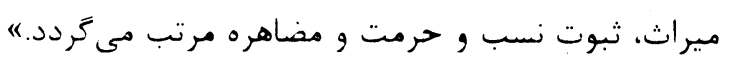

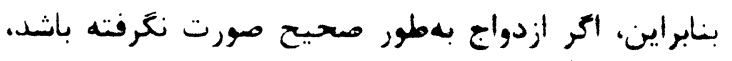

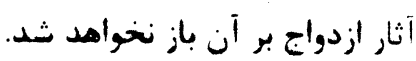
برابر بند دوم مادة الط قانون مدنى الففانستان "اعقد نكاح

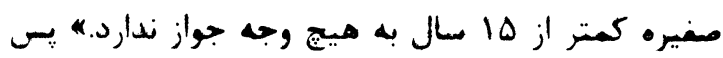

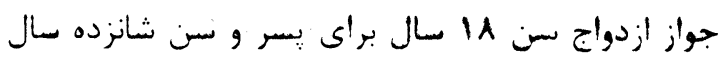

]ם على پييام طرح مسأله: سـن ازدواج بـراى دختــر و يـسـر همـواره مـورد توجـهـ

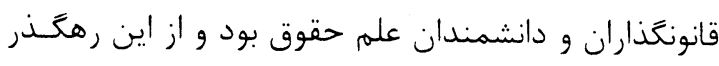

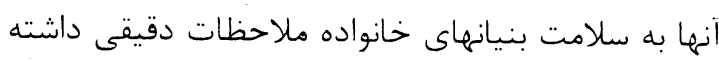

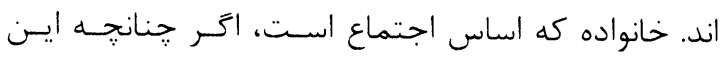

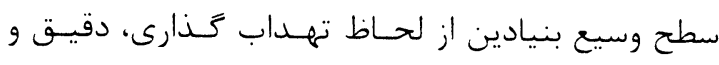
حساب شده باشد، بالطبع، جامعه داراى وضعيت نورمـال

$$
\text { و سالم خواهد بود. }
$$

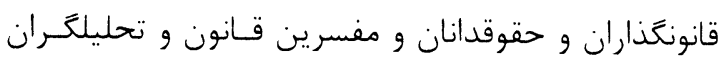

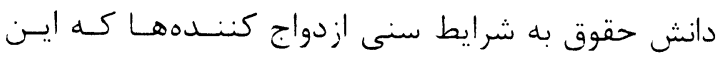

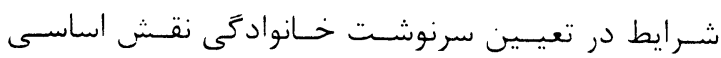

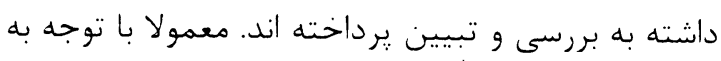

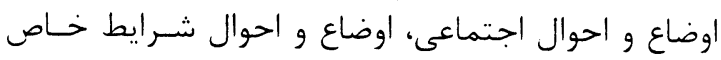

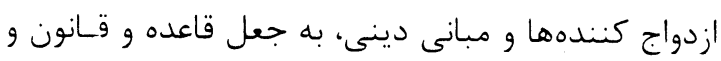

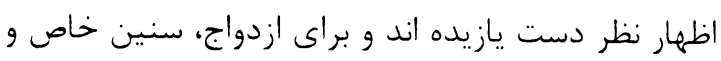

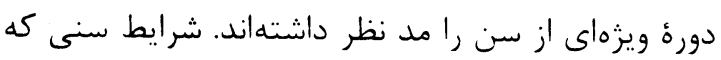

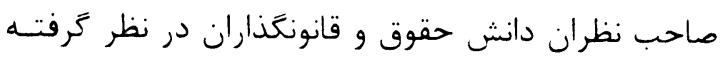

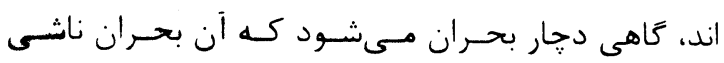

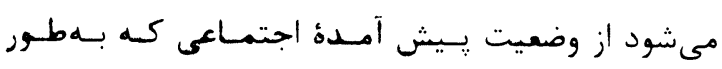

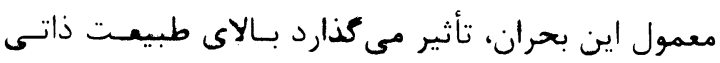
شرايط سنى خاص براى ازدواج. 


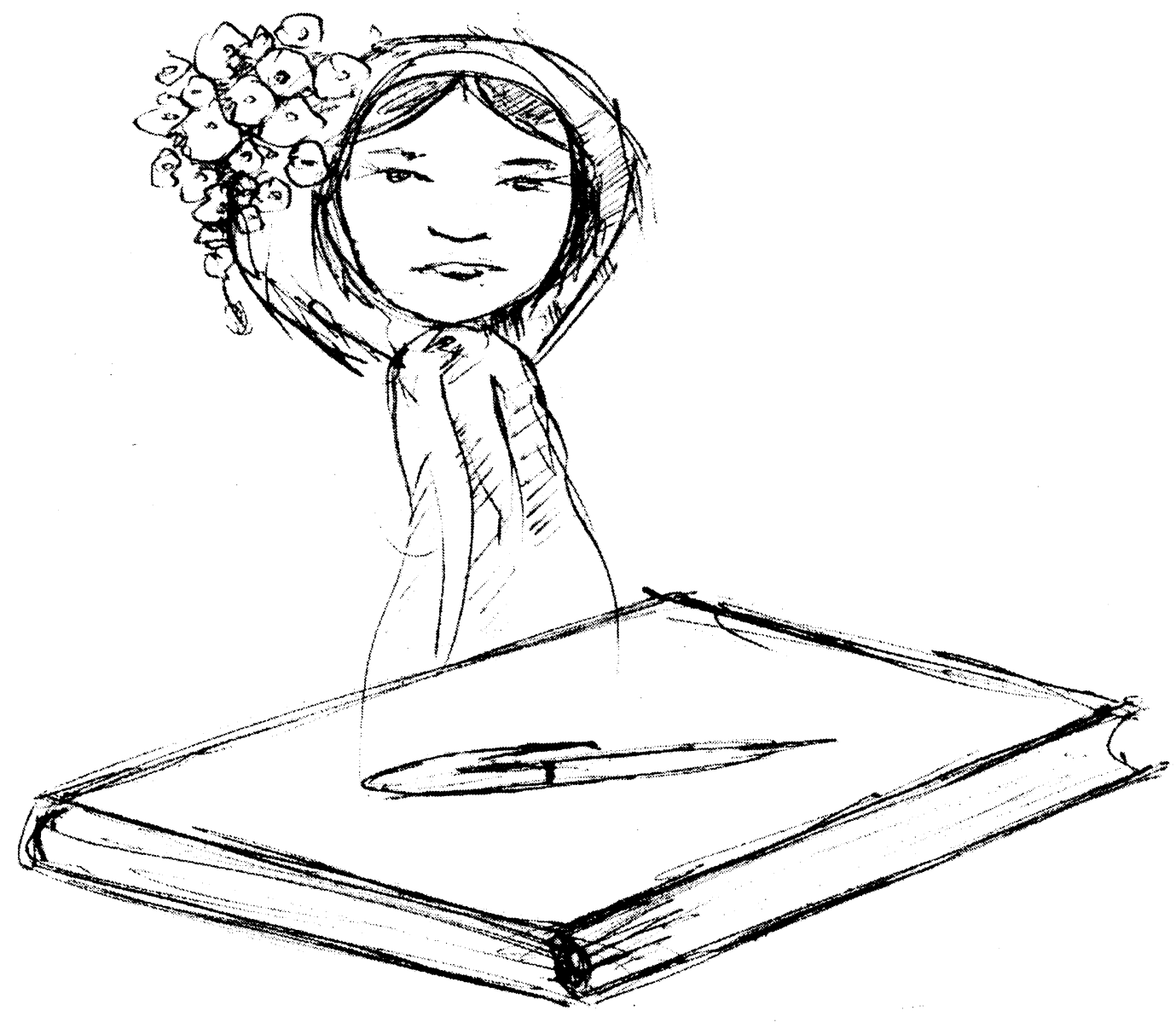

اش قصد و رضا را در متن خود نهفته دارب، قصد و رضا كه به مقصد تشكيل فرايند زندگى مشترى منجر گردد و حقوق و واجباتى را به ذمهٔ طرفين محقق نمايد. قصد و رضا، تحقق حقوق و واجبات، از جمله تعلقات و مربوطات افرادى است كه در سنى خاص و شرايط سنى مناسب قرار زرفته باشند و يا طرفين اهليت ازدواج راجئ داشته باشند. مطابق مادة VY قانون مدنى افغانستان "براى صحت عقد نكاح و نفاذ آن شرايط آن، لازم است: آ- انجام و قبول صحيح...٪ و برابر مادة \&ء قانون مذكور لاعقد ازدواج به ايجاب و قبول صريح كه فوريت و المتمرار را لهاده كند... صورت مى ميرد." ايجاب و قبول مبتنى است به الهليت ازوفواج.
براى دختر مد نظر گرفته شده. اين مطلب در نظامنامة نكاح و عروسى مصوب . . 1 ا شمسى(قوانين مدونه عصر امانالله) نيز ذكر شده. اين قانون در مادة هـ مى مويد ״انكاح قبل از بلوغ موقوف شده" و در مادة 9 اشاره دارداعقد نكاح قبل از سن سا سالگى نبايد صورت بخيرد. قانون مدنى افغانستان در مادة .9 ازدواج را عقدى دانسته كه معاشرت زن و مرد را به مقصد تشكيل خانواده مشروع گردانيده، حقوق و واجبات طرفين را به وجود مىآورد." اين عقد تابع قصد طرفين ازدواج كننده است، قصدى كه از روى فهميدگى باشد و فهميدگى مبتنى است به رسيدگى فكرى و جسمانى، قصد و يا مقصد تشكيل خانواده، ايجاب و قبول مى خوامد، ايجاب و قبول مفهومى است وسيع و كسترده كه در يك جلوه 
روحانى مسلم نباشد، راجع به تأثير قواى جسمانى پدر و مادر در فرزند هيجگگونه ترديدى نيست.

نتيجه:

مطابق قانون مدنى افغانستان، دختر و يسر بايستى در. هنگام نكاح داراى اهليت باشند. يعنى، يسر سن هجده ون دختر سن شانزده سالگى را تكميل كرده بأشد. و نيكاح. دختر كمتر از ها سال به هيج وجة جواز ندارد.

\section{واقعيتهاى موجود}

تا اينجاى مطلب، شرايط و زمان سن ازدواج را برابر موجود قانون موضوعه افغانستان دانستيم. ليكن، متأسفانه، واقعيت جيز ديخرى است. واقعيتى كه بحران خانواگى و

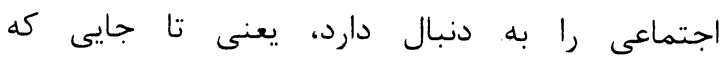
نغارنده(همين جند هفته يِيش) سفرى كه به افغانستان داشتم، واقعيتهاى نامطلوبى را مشاهده كردم. در مناطق ئن مركزى دختران خردسالى را ديدم كه به زنى داده شده رانه بودند، دخترانى كه هنوز بوى شير از دهانشان دردان مئى آمد. دختران نه ساله ، ده ساله را مشاهده كردم كه به خانه بخت فرستاده شده بودند. دخترانى كه خاله بازى و و داله كدى بازى، تنهاءلِّسبى آنهاست. بايستى در اين سن و

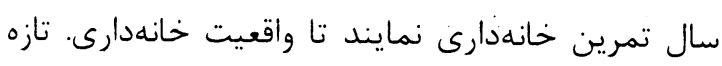

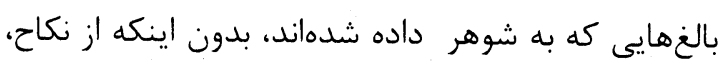
شوهردارى و خانه دارى جيزى بفهمند. اين دوشيزهان خردسال كه دست راست شان را از دست جِي شان نمىتوانند تشخيص بدهند. بدون اينكه لمقصد تشكيل خانوادهه مدنظر شان باشد و يا قصد و رضا برايشان

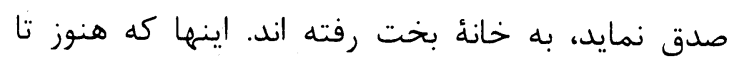

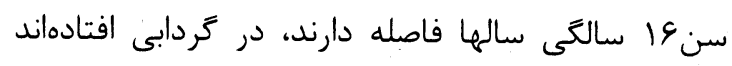
بنام خانهدارى كه در آن فقط دست و يٍا مىزنند و خانهدارع برايشان مفهومى بسيار بيجيده و مشكل إست.

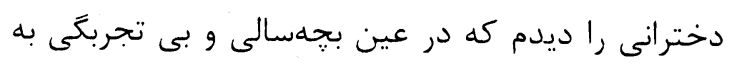

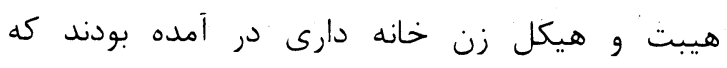
خودشان تصور روشنى از آن نداشتند. اين كودكان معصوم به جاى بازى و تمرين خانهدارى بايد با حقيقت

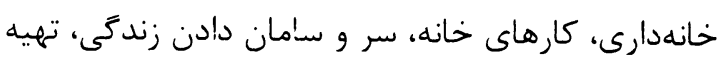

قانون مدنى ايران قبل از اصلاحية سال اعبا سن ها

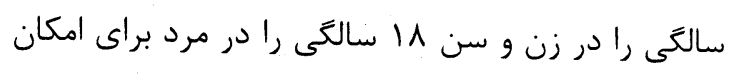
ازدواج لازم شمرده و در اصلاحئ سال اعبا در در مادئ

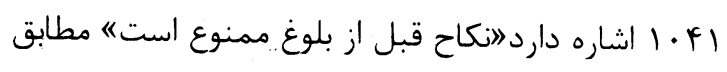

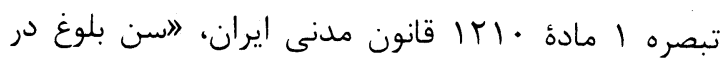
يسر ها سال تمام قمرى و در دختر نه سال تمام قمرى

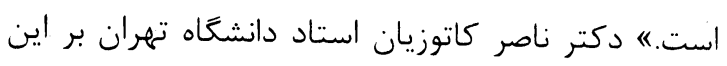

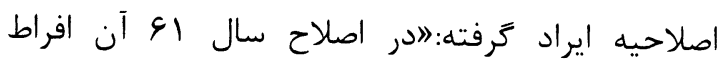

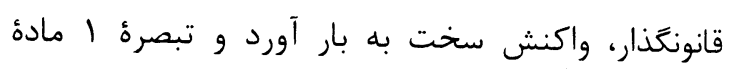

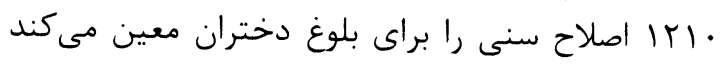

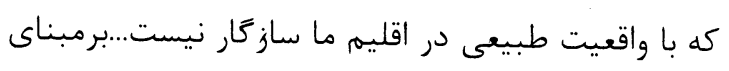

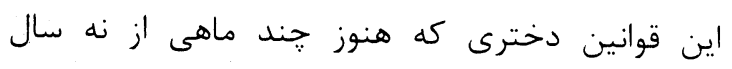
شمسى كم دارد، اهليت نكاح دارد و وخت صلاحيت مادر

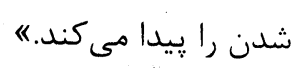

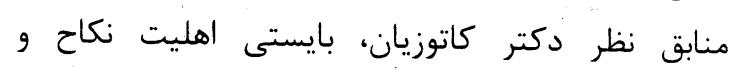
صلاحيت زن شدن را با توجه به واقعيت طبيعى و وكتئ بانيت اقليمى ملاحظه كرد. بنابر اين، در مواردى كه دختر از نظر شرعى نه سال تمام قمرى را طى كرده باشد، اما

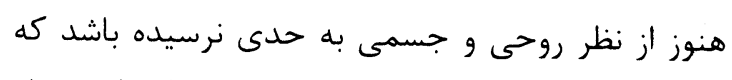

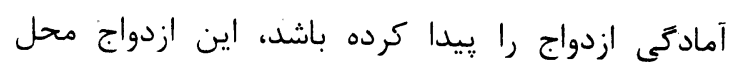
اشكال و تأمل است.

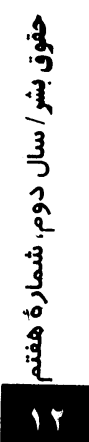
آن جيزى كه قدر متيقن است اين است كه ازدواج قبل از بلوغ جايز نيست. قانون مدنى افغانستان، حساب شده و دقيق با مسأله برخورد كرده و شرايط و اوضاع و احوال

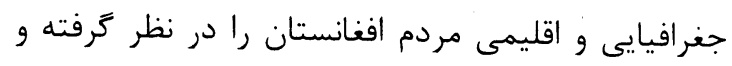
رأى داده است. براى اين كه نكاح در سن خام جايز نيست، حقوقدانان دلايلى آورده اند؛ از جمله دكتر سيدعلى شايعان(حقوقدان ايرانى) اظهار نظر كرده است: "براى تعيين حداقل سن نكاح علل مختلف مىتوان ذكر إنى نمود از آن جمله اولا، براى اين كه صحت زوجين و

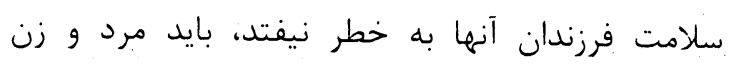

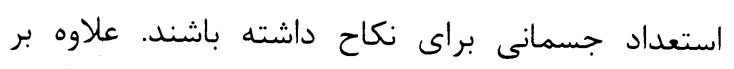

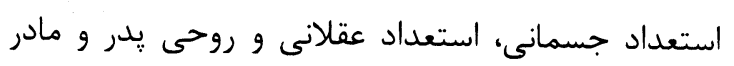
در فرزندان آنها دخالت دارد. در هر حال، اتر تأثير قوائ لئي 
در افغانستان خصوصا در مناطق مركزى، دختر داشتن براى شرايط فعلى يك غصه است. همين كه والدين دختر شاهد قد كشيدن دخترشان مي باشند. بايد شب و روز مواظب باشند تا به زور برده نشوند. نمونهها و وريد

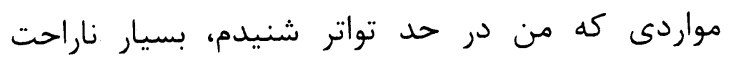

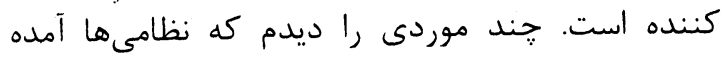
بودند براى به زور بردن دختر خانه، قبل از قبل يدر خانه از ماجرا اطللاع يافته بوده، در شب رود سرد برد زمستان، يدر دخترش را برداشته مىبردش در كوه و تا صبح مىماند وقتى مطمئن مىشود كه تفنگداران خانه اش را ترك كرده اند، بر مى گردند خانه. مواردى را مشاهده كردم كه نظامى ها آمده بودند و دخترى را به زور بسته كرده و برده بودند، اهل خانه

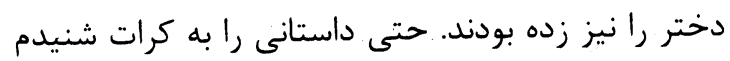

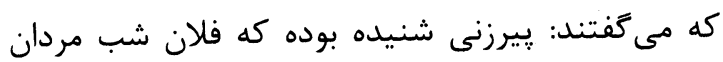
تفنگدار براى ربايش دخترش مى آيد. وقت تنگ بوده و فرصت براى جاره انديشى نبوده جز اين كه لباسهاى

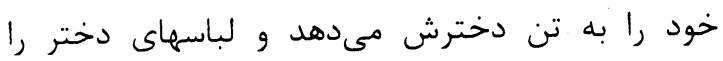
خودش مىيوشد. شب هنگام كه افراد مسلح مى آيند، ״يرزن را به جاى دخترش مىبرند خانه خودشان تا يكى از آنها وى را به زنى بكيرد. ييرزن تا فردا صبح نه صورتش را باز مى كند و نه جيزى مى گويد. فردا صبح همه جيز برملا مىشود. آن وقت رباينده حيران مىماند

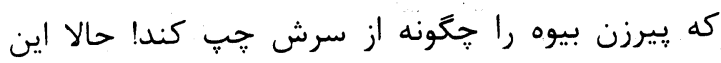
داستان به فرض اين كه خيالى باشد، اما كمتر از واقعيت

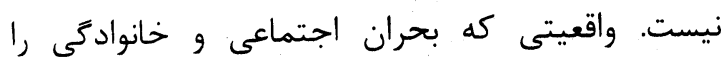
بdوجود آورده است. جه اين كه تفنگدارى دخترى را به زور برده و يا والدينى الدى

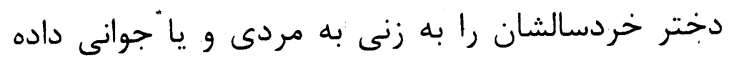
باشد، در هر دو صورت، در اين ازدواج قصد تشكيل

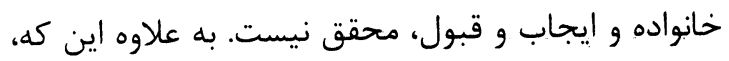

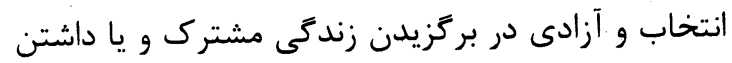
سن قانونى براى ازدواج، در اين جا موجود نيست.
و تدارك امور زندگى زناشويى روبرو شوند، موقعيتى كه اصلا مناسب آنها نمىباشد. زلردي اين بجههاى خردسال و صغيرى كه من ديدم، نه مفهوم ازدواج را فهميدهاند و نه به انتخاب خودشان اين جزيره

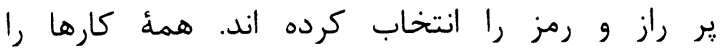
اطرافيانشان ترتيب داداند. انتخاب شوهر، تصديق و تأييد يعنى رضايت، قصد تشكيل خانواده و غيره از سوى

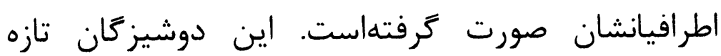
روييده در برابر خودشان ناگمان مردى را مىبينند به نام

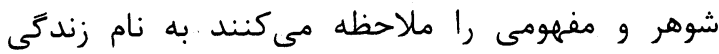

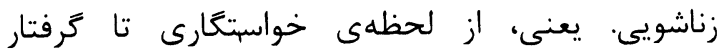
موقعيت زن شدن، جيزى را نمى دانند و نمىفهمند و در آن شرايط سنى نيستند كه از ازدواج سر دربياورند. نا خواسته در موقعيت ويزهاى قرار مى صحيح و درستى از آن ندارند. ازدواجى كه برابر شأن سنى و شرايط روحى و جسمى دختران نيست و .قانون نيز بهعدم جواز آن اشاره كرده است.

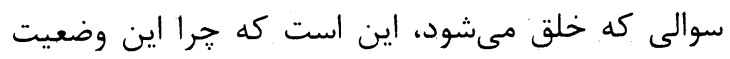
در جامعه افغانستان ييش آمده است؟ علل و اسباب موجدة اين وضعيت جيست؟ بايستى توجه داشت كه اين اوضاع و احوال از بحران اجتماعى و احوال نابسامان حاكم بر جامعه افغانستانى ناشى شده است. اوضاع و احوالى كه بهطور جبرى و قهرى، اين سيستم تشكيل خانوادگى را به وجود آوده است. در تشريح اين موضوع اين گونه مى توان اشاره نمود كه وضعيت هرج و مرج اجتماعى، نظامى قانونى، بىبازخواستى كه بر اثر سالها حاكميت بلامنازع جنَ ايجاد شده، مردم افغانستان را درست در موقعيت عرب قبل از اسلام قرار داده است. يعنى، هركه دخترى ولو خردسال در خانه دارد، جه حال و روزگًارى بايد داشته باشد؟ طبعا يا شاهد ربايش به زور دخترش باشد

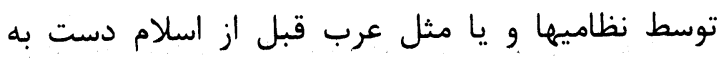
زنده به گور كردن دخترشان بزند. 

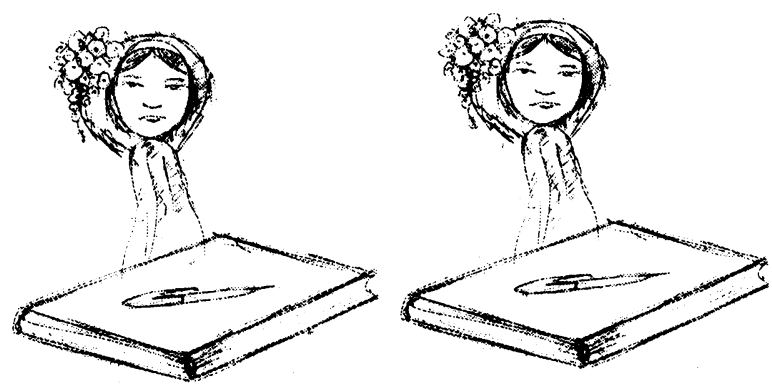

مشترك حق تعيين سرنوشت دارند، اما تصميم كيرندة

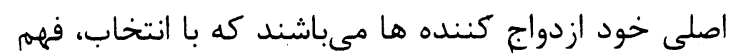

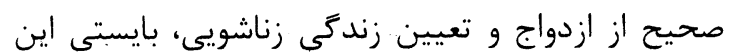
مرحله را برتزيند. البته، رعايت نكردن سن قانونى ازدواج دختران، هميشه

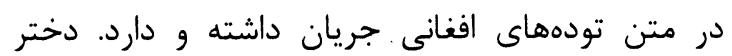

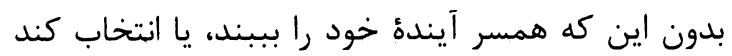

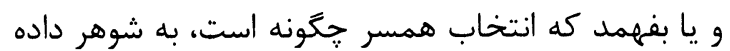

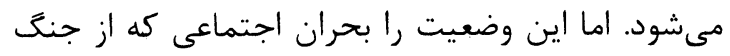

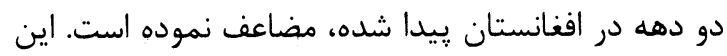
تضعيف دو ييامدشديد داربد:

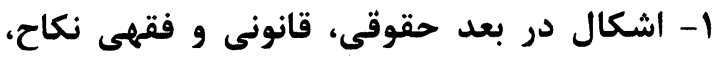
r- منجر شدن به جدايى كه هر دوى اين دو مورد

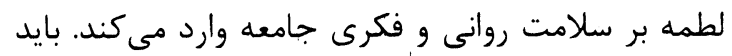

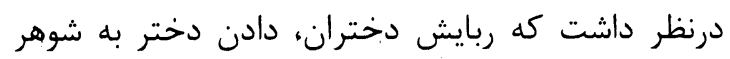

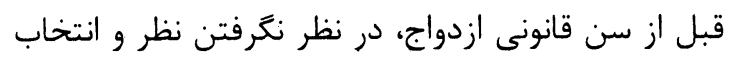

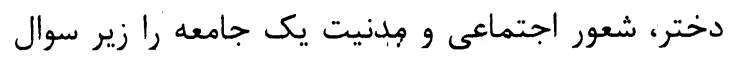

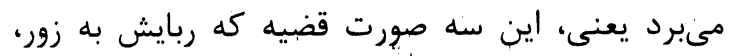

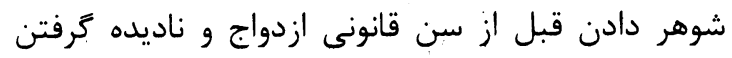

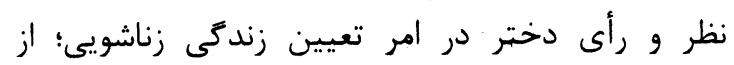

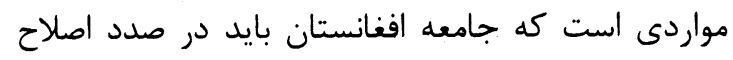

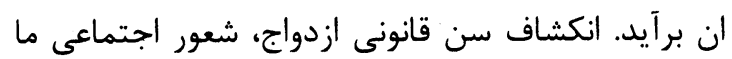

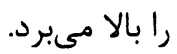

با توجه به مطالبى كه گفتته شد سن قانونى ازدواج از

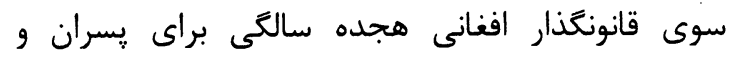

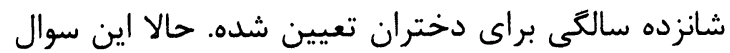
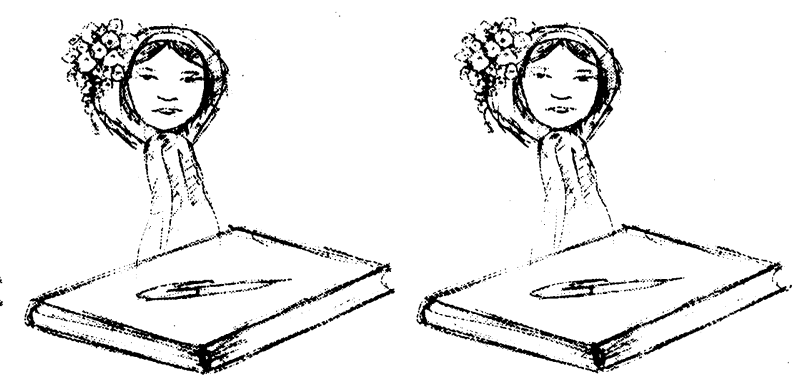

والدين، در شرايط نابسامان اجتماعى و وضعيت جنكى،

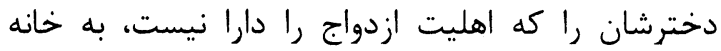

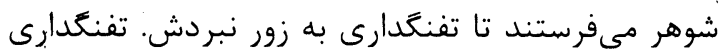

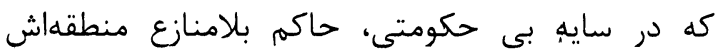

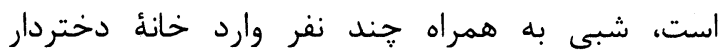
مىشود و با بستن اعضاى خانواده، دختر را مىبرد خانه

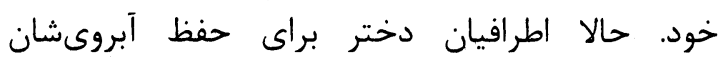

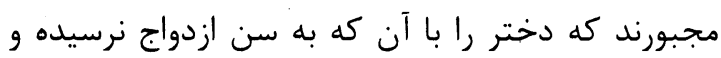

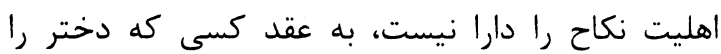

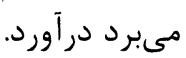
تصور اين موضوع كه ناتهان جند زورد زوردآورى وارد خانه

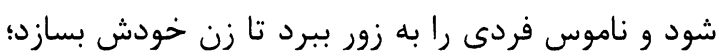

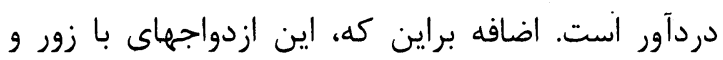

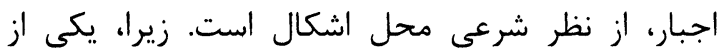

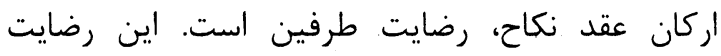
طرفين در دو بعد قضيه منتفى است، يعنى هم در

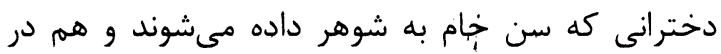

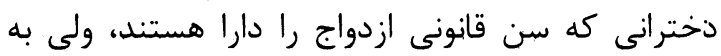
زور وادار به عقد مىش كنوند.

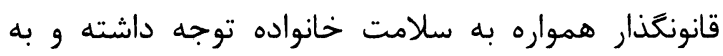

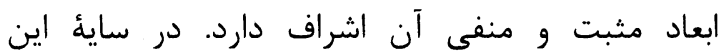

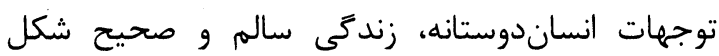

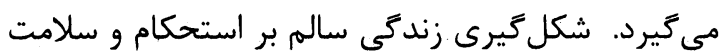

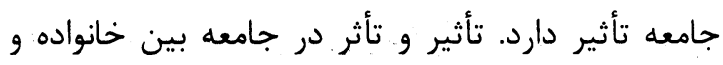

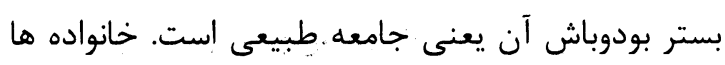

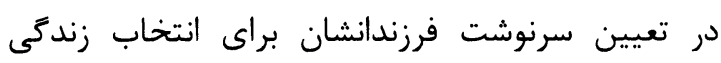

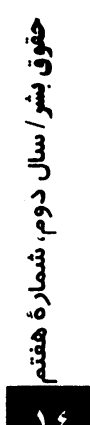

$1 \varepsilon$ 
و اگر مفسدهاى داشته مىتواند آن را امضاء يا رد نمايد... نتيجه كلى: دانستيه كه براى ازدواج از سوى قانونگذار افغانستان،

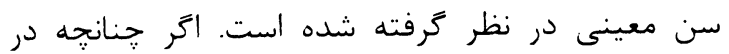

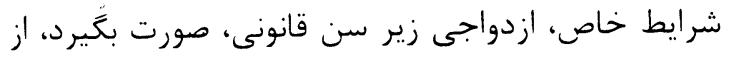

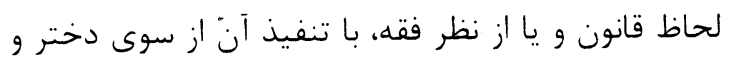

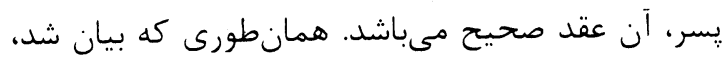

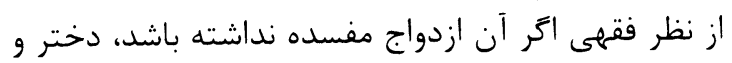

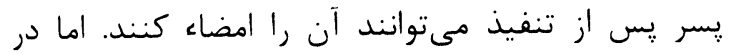

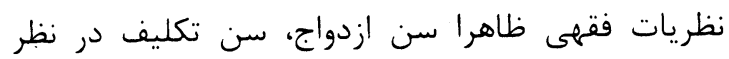

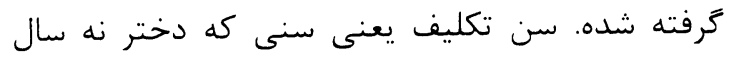

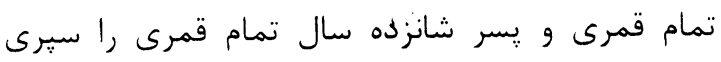

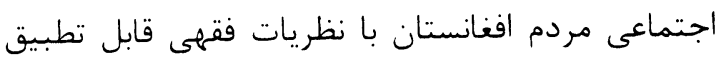

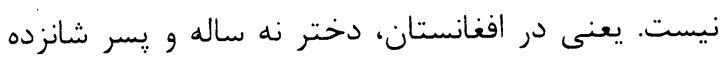

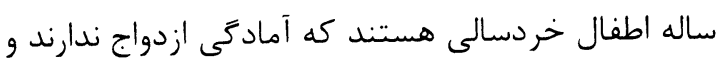

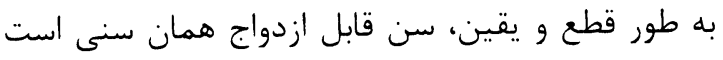
كه در قانون مدنى افغانستان لحاظ شده است و و همين الردين

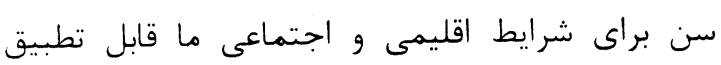
است.

منابع: - من

- قانون مدنى افغانستان، جريده رسمى، صدها، كابل.

افغانستان

- حقوق خانواده، ج ا، با اهتمام يدالله باز گير، \^، تهران قانون مدنى ايران

- رساله توضيح المسائل، آيتالهه قربانعلى محقق كابلى، • ^، قم - فصلنامه صدف، سال سوم، شماره بار (مقاله نفيسه

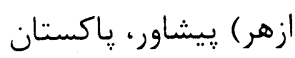

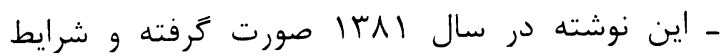

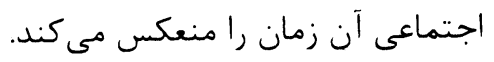

پِيش مى آيد كه وضعيت نكاح أن دسته از دخترانى كه

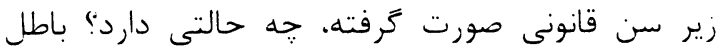

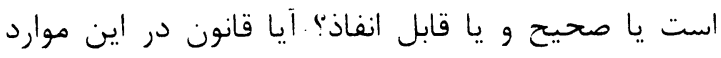
بيش بينى خاصى كرده است؟

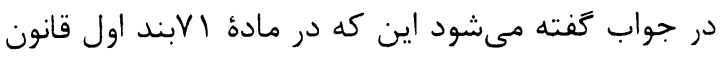

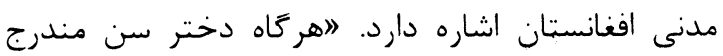

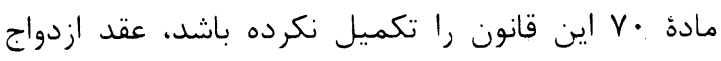

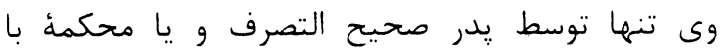
صلاحيت صورت مى

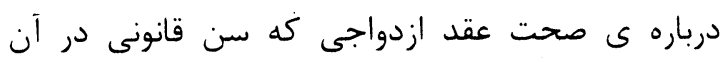

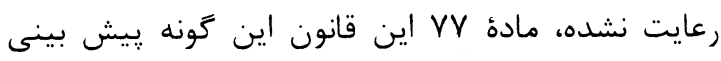

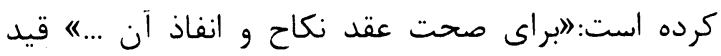

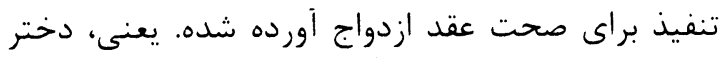

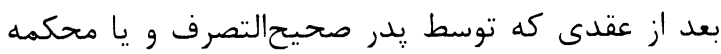

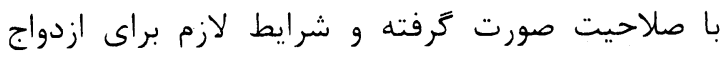
يافته، مىتواند با تنفيذ عقد، صحت عقد صدات را به به جريان

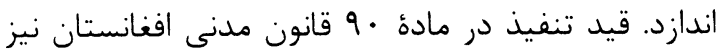
ذكر شده است. "ابر نكاح صحيح و نافذ تمام آثار آن ...

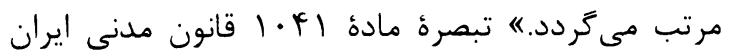

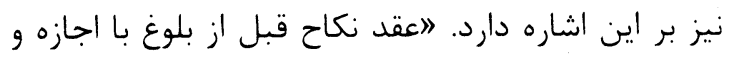

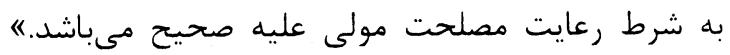
أيتاللهالعظمى محقق كابلى از فقهاى شيعيان افغانستان

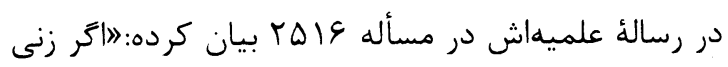

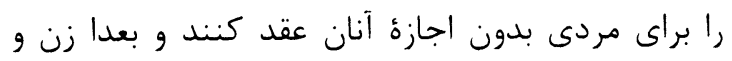

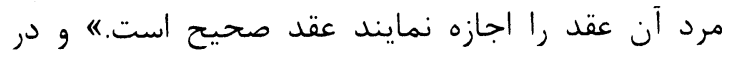

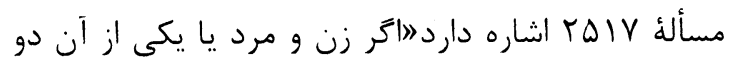

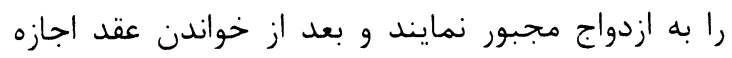

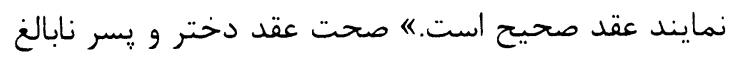

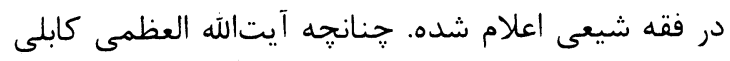

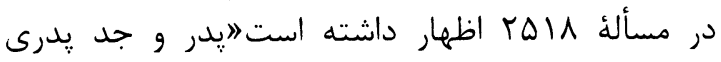
مىتوانند براى فرزند يسر يا دختر نابالغ...خود...تزويج

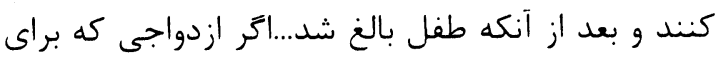

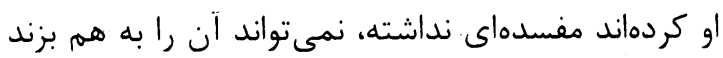


كيبري او د هغوي انساني شخصيت او حيثيت ته به تيتهه ستر كه كتل كبوب. زموبج دهيواد يه كليسو، بانسلهو او بنسارونو كي بنستحي د بيالابيلو فشارونو لاندي دي، كورنى فشار، تولنيز نساوره هلند، د ناوره دودونو او رواجونو لاسبرى، هغه لاملونه دي اجي بنحُحي د فشار لاندي راوري او هغوي د تهولنيز زؤند د يوب سترى برخى يه تو گه له خهلو حقونو خخــه بى برخي كوي، يه تولنه كي د بنسحي حضور د شسرم ورة كرحوي، د زده كرو، خيل اختيار او د تولنيز زونسد يسه تولو جاروكي يب د برخي

$$
\text { اخيستني مخنيوي كوي. }
$$

كوم لاملونه زموبج د تولني د بنحخو يه ور اندي خحنلهونه جوروي؟ ولى د بنسحو يسه وراندي لله توبيرونسو كـار اخيستل كيب.ي؟ او ولى د بنحُو يه وراندي زور زياتى كيري؟ دا مغسله يوبنستني دي وجستي بايد حُـواب ورتسه مونسل

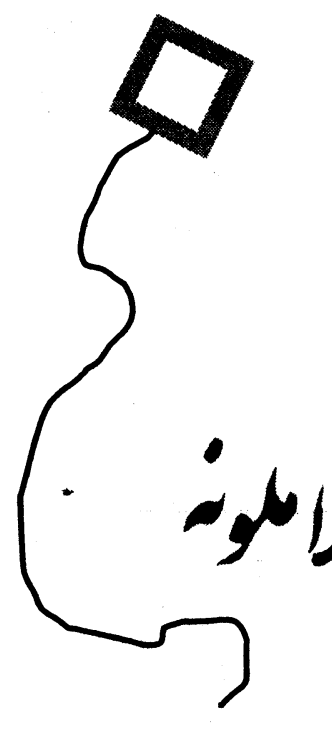
شي او به دي تو كه بنحخه د انساني هستي د يوب لوري او بوتم لرونكى موجسود بـه تو گه وييزندل شي، حقوق يب برحاى شي او د درنساوي او درنبنت ورج وترحي. هغه لومرى لامل جي د بنسخو دحقوقو به ورانسلي خنسله جوروي، زموب جه تولسه كي د عمسومى سسراد د كهيى تيتوالى دي، دا لامل ددي مسبب كرحمي جسي د بنسخي

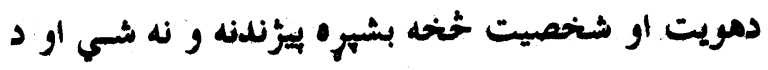
دويم موجود به تو كه ورته و كتل ثي.
زموبج دهيواد به تاريخي بهير كي افغاني بنحخي د تولني د

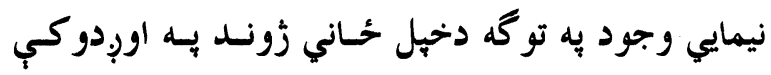

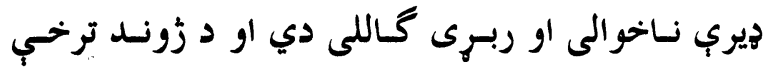
ورحي شبي يب سبا كريدي. خحه به الهي قوانينو او خهه به موضوعه اصولو او قوانينسو كي بنسحه د انساني برتم او د مينى، محبت او اخلاص د د سرجينى يه تو گه ييزّندل شـوى او درنساوي يسي برحساى

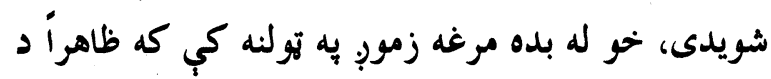
بنحخي او دهغوي د بنستزو حقوقو يادونه او ستاينه شوي
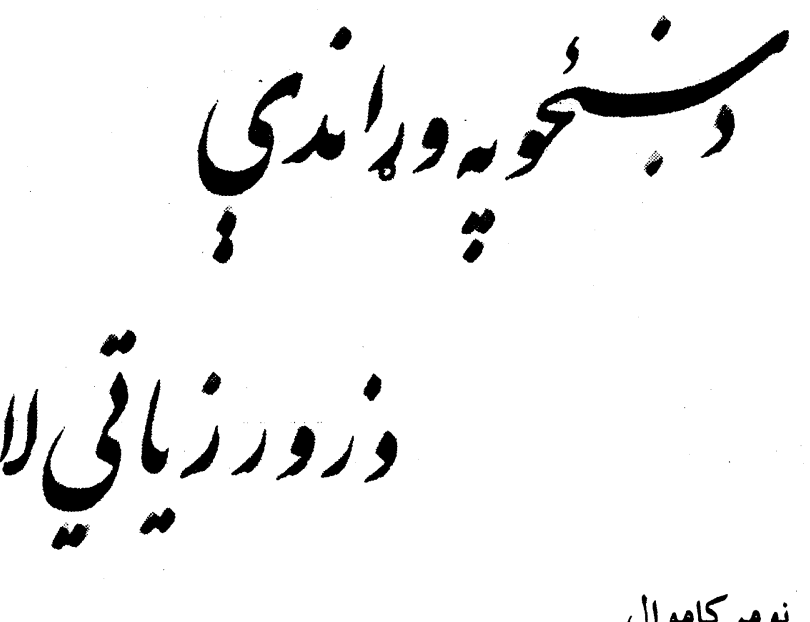

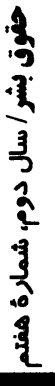

17
خو به عمل كي د دغو سـتاينو سـره يسو حُساى د زيساتو ناخوالو او ربرو خحخه برخمنه شوي ده. زموجٍ د خبرو اساسـى زرى يسوازى بـه خـو بنسارونو او يلازمينه كي د زده كرو خحاوندو بنسحوته مترجه نسه دى، بلكي موج دمغه ستونزو زورزياتيو او تاوتريخوالي حخحسه

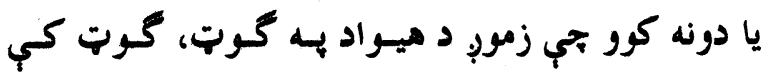
زمورج لومتي او نالوستي بنحخي ورسـره منحسامني دي او

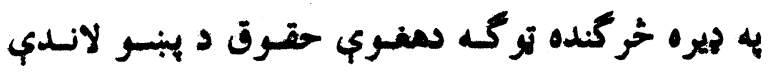


كورني زوند ته هم غزيوي او ددب لامل گرحئ بجي يسه

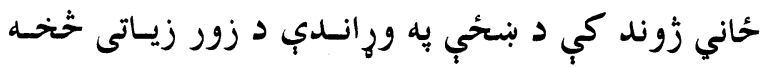

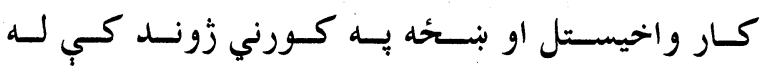
تاوتريخو الي سره مخامخحه شي.

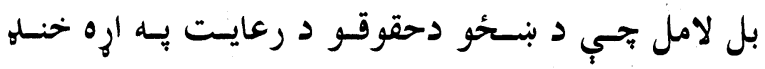
رامخكي كوي د فقر شته والى دي، د فقر به شتون سره

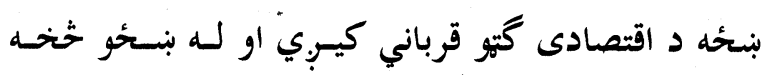

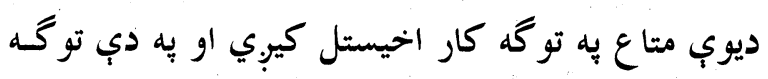

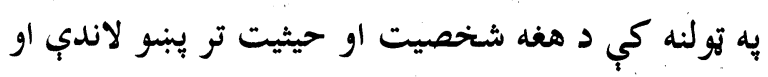
دخبلو حقه حقونو بى برخي باتب كيوي.

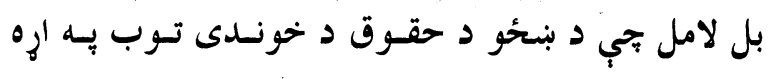

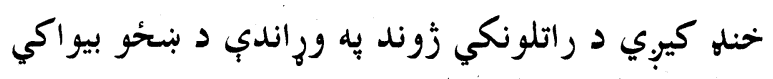

له بده مرغه زمورج. د تولني به ذيرو برخو كي بيغلى ددي

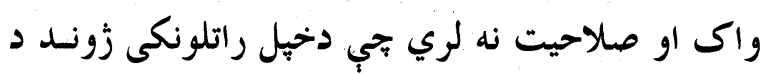

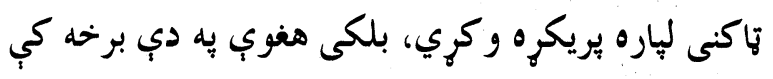

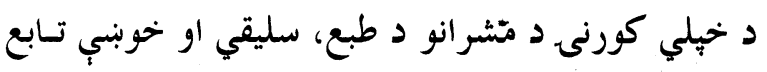

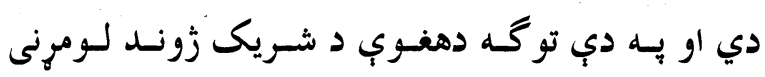

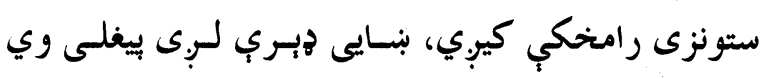

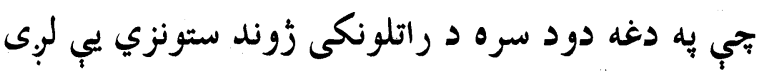

دا خر گنده ده بجي د بيويو، بيريو راهيسى زمور. تولنسه د

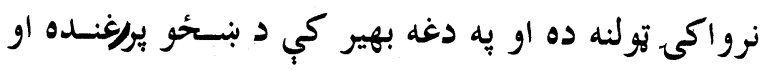

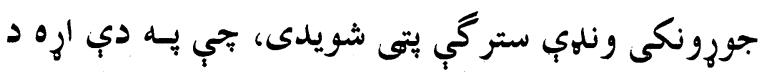

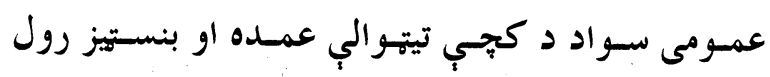

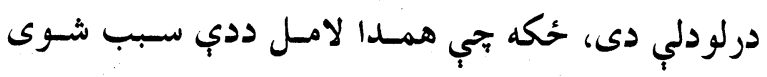

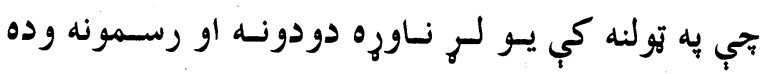

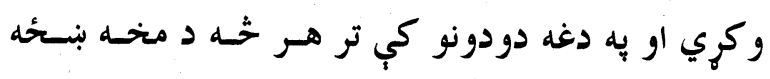

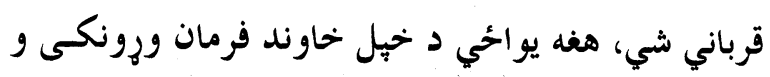

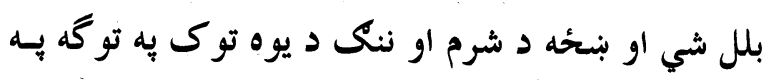
تولنه كي معرفي شي.

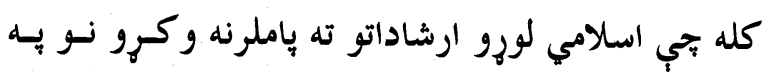
كرارتو كرارتو به به متبركو قرآني آيتونو كي ولولو تجي لوري د بنحئو سره دورين تندي برجال تحلند تينگار شوي، يسه

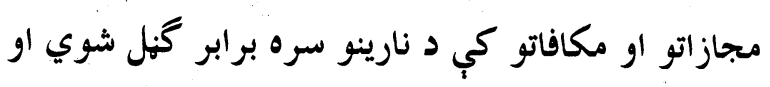

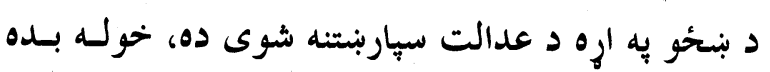

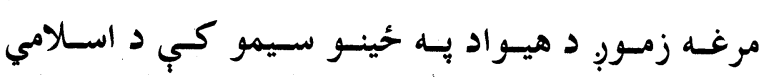

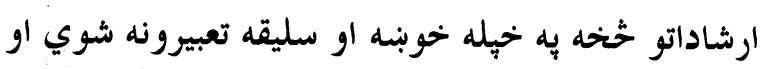

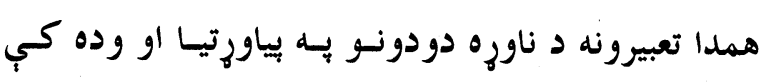

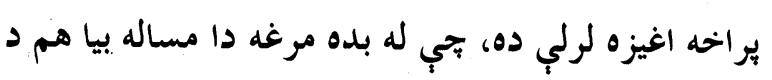

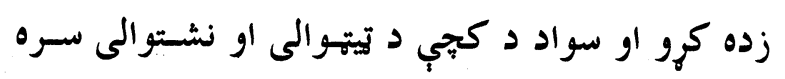

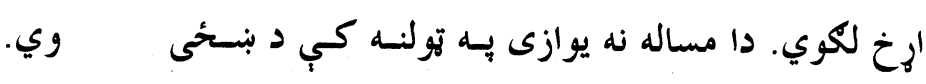

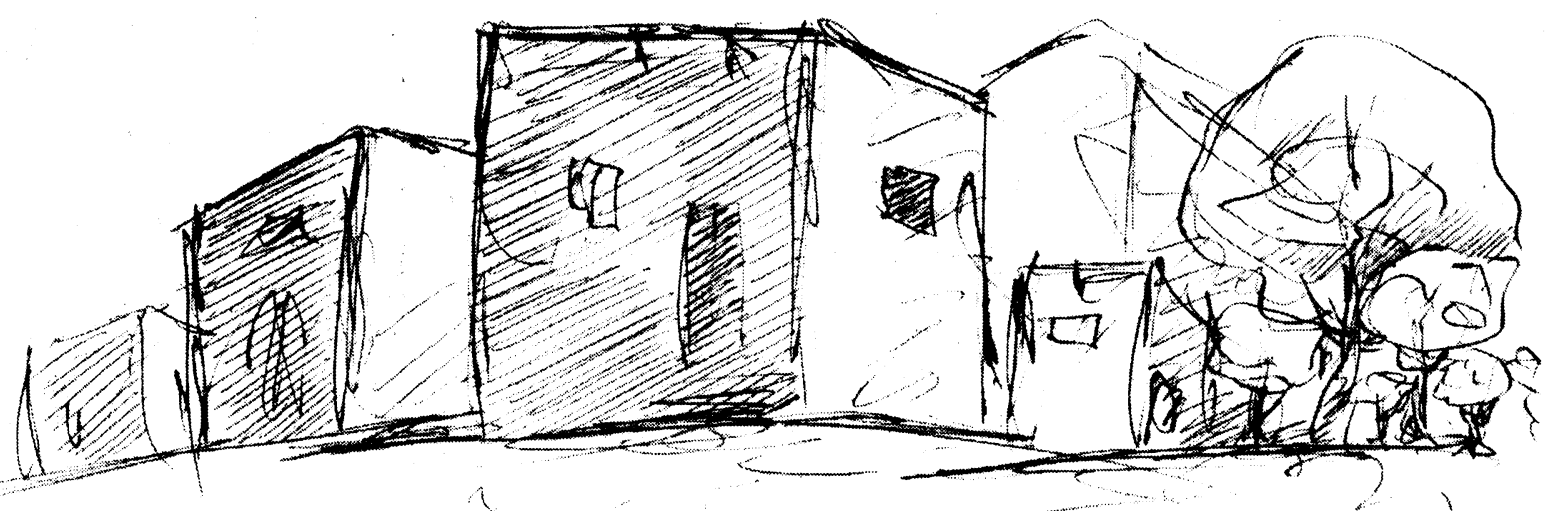


خر گند واقعيتونه دي جـي بايسد باملرنسه ورتسه وشسي او ستونزو ته د حل لاره وموندل شي.

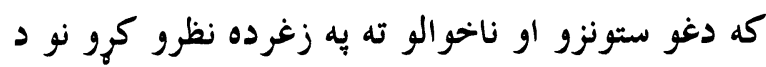

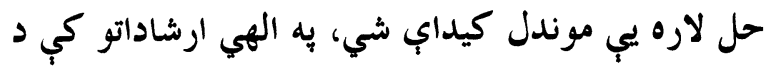

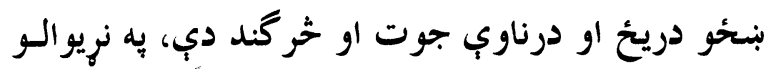

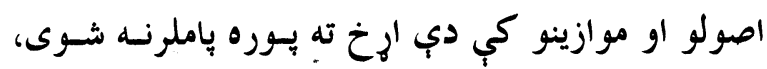

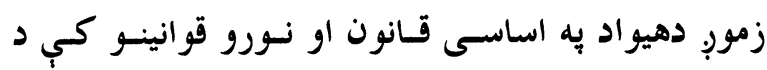

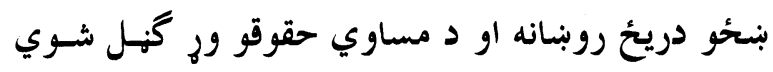

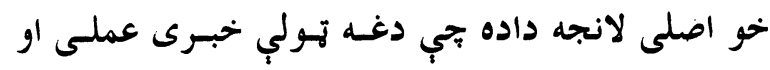

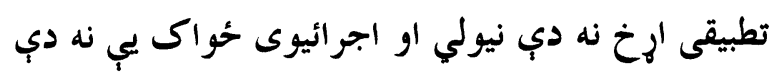
ترلاسه كري او تر اوسه افغاني بنسخى د هيسواد د دتهولنيز

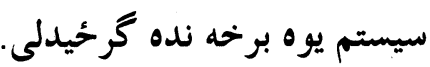

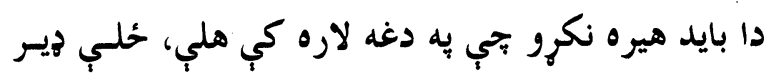
وخت غواري جي زموب. به تولنه كي د بنستحي دريسخ يسه

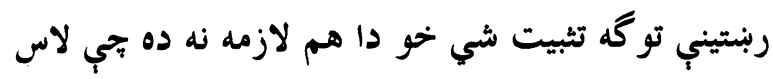

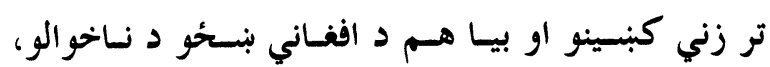

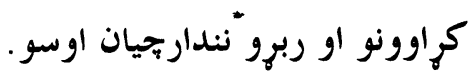
هيله داده تي دولت، مسوول ارگًانونه، دينسي عالمسان، يوهان، حقوق يوهـان، د بشـري حقوقـو تهولني، مسدني

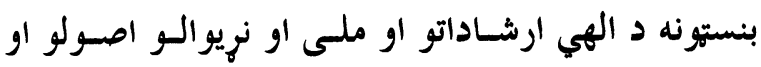

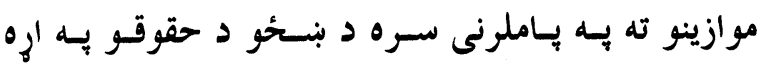

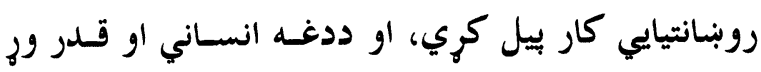
موجود به وراندي ذهنونه داسى روبنانه كري جي هغوي د تولني دويم موجود نه بلكى لومرنى موجود و گنزل شي جي انسانى هستسى او يايبنست دهغسوب لـه بر كتسه دوام مومي او انساني زُوند بنكلا ترلاسه كوي. لئي
كله تي د راتلونكى زوند به تهاكنه كي د يبغلو خوبنب ته

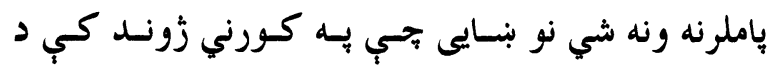

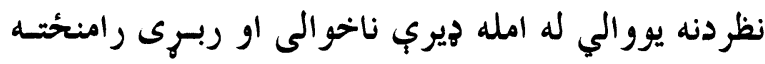

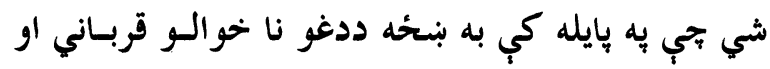
زُوند به يب د زورزياتى او تا وتريخوالي سره مل بل وي. يه دغسب يو حالت كي بنحخه داحق نلري تجي د كسورني

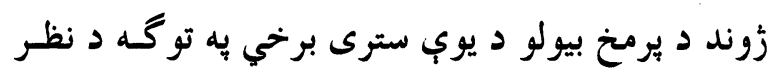

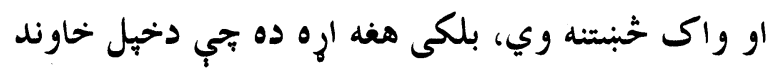
او د كورنى د نورو مشرانو، هيلو او غوبنستنو تسه غساره

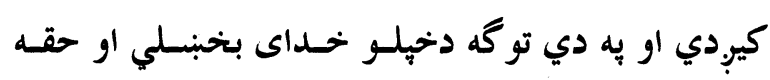
حقونو خُخه بـ برخب باتى شي.

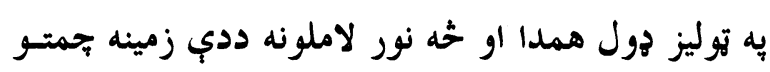
كوي تجي د بنحخو به ورانسدي لـه توييرونسو خخهـه كـار واخيستل شي او د تولني به سياسي، اقتصادي، فرهنكي إ - - -

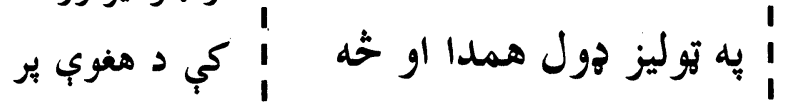
ا إنسـى شــــي او

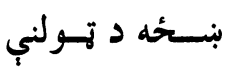

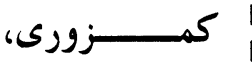
ناتوانه او بيوسه موجسود و كنهل أ نور لاملونه ددي زمينه

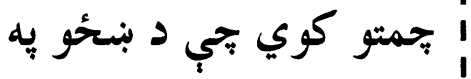
أ وراندي له توبيرونو خخه إ كار واخيستل شي او د د إن أ تولني بيه سياسي، اقتصادي، له له كومو مسايلو ا خخحسه مسو جهب هورتسـه يادونسـه

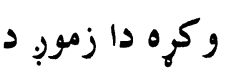
ا تولني د بنسخينه

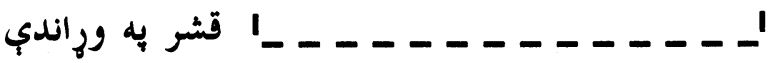




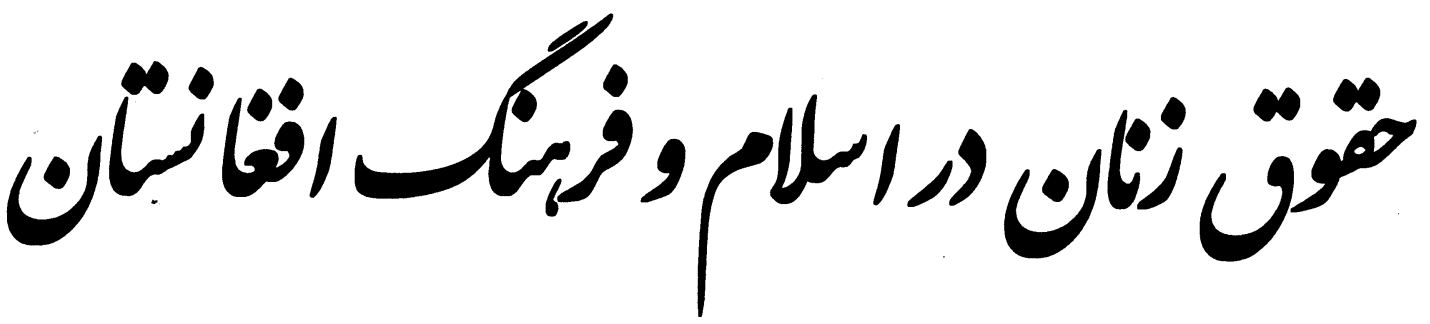

آن كس كه تاريخ و سيرة يِامبر(ص) و بزركان دين رأ ل

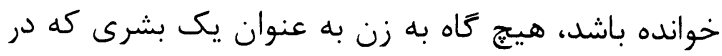

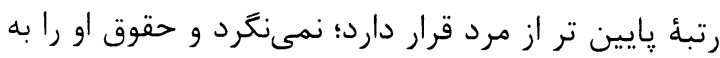

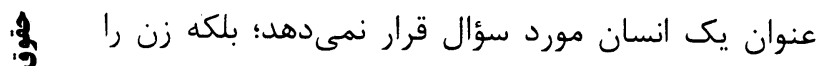

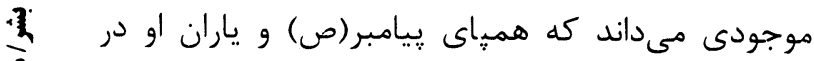

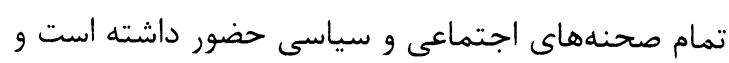

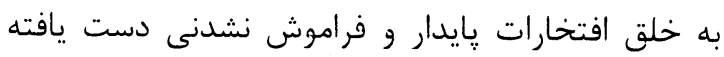

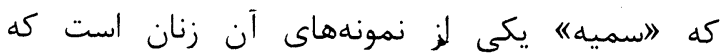

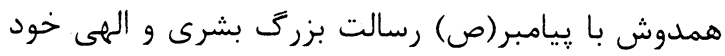

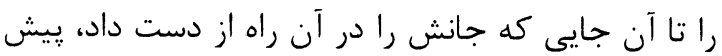

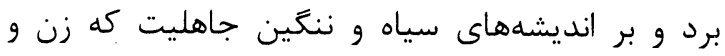

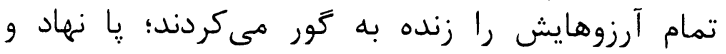
زهرا(س) آن بانويى كه با همت ستودنى و غظهم استوار

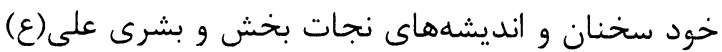

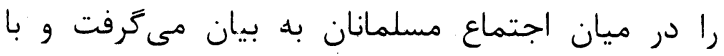

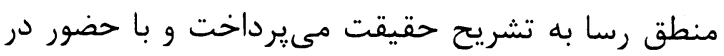
صحنه هاى مبارزات سياسى از ايده هاى شوهرش به

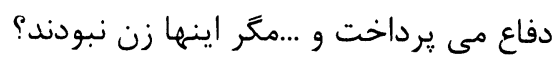

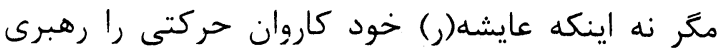
نمود و با دعوت بسيارى از مسلمانان محور يك جريان

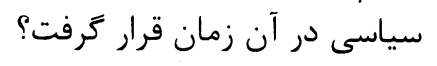

بحـث حقــوق زن در اسـلام از جملـهـ بحثهــاى بسـيار

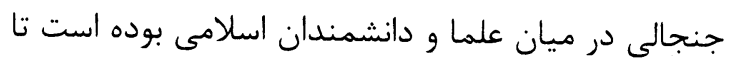

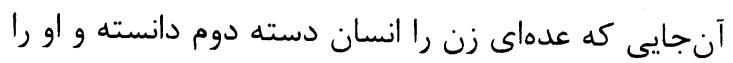
از بسيارى از حقوقى كه بايد يك انسان برخوردار باشـد، ردها

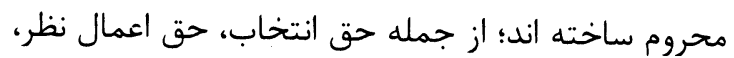
حق حضور و فعاليت در اجتماع...

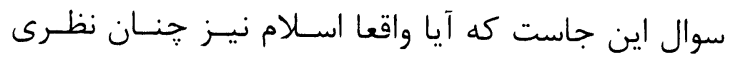

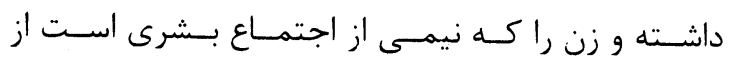

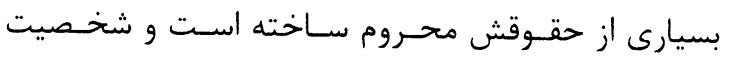

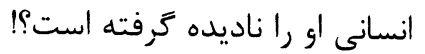

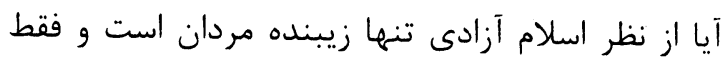

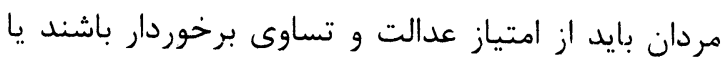

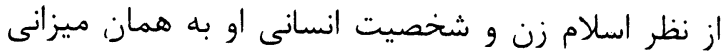
مورد توجه است كه شخصيت مرد قابل توجه بوده

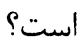

كسى كه از اهداف اسلام اندكى آكاهى داشته باشد و

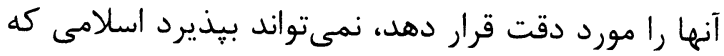
يكى از مهمترين اهداف آن تحقق عدالت و برابرى ميان انسان ها است، حقوق نيمى از جامعه انسانى را ناديده

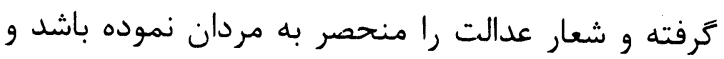


جزء تقوا است و اخرنه خدا هرگز به عبادت ما و شما احتياج ندارد؛ زيرا او غنى است و تقوايى كه او مى گويد اگر يك سر آن به خدمت خلق الله وصل نگردد، تقوا نخواهد بود و مراعات حقوق مردم از بالاترين خدمترها به آنان است كه به طور قطع زن را نيز نمعىتوان از ان استثنا كرد. بنابر اين، اين سوال مطرح مىشود كه وقتى اسلام به انسانيت زن صحه گذاشته و حقوقى براى او همياى مرد در صحنههاى اجتماعى و سياسى قائل شده، يس جرا جهره زن در جوامع اسلامى در هالهاى از ابهام و حتى

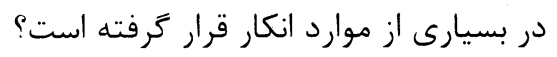
متاسفانه بايد بكوييم وجود بسيارى از نصوص نير غيرمعتبر روايتى و تاريخى كه حتى در كتب معتبر فرقهها و مذاهب اسلامى وجود دارد و ثبت شده است، باعث شده اين شبهه به وجود آيد و نيز تمسك به ظاهر بعضى از روايات معتبر كه بايد با تكيه بر نصوص قرآن و سيرة ييامبر و روايات محكمم و صريح تفسير زردند، اين شبهره را تشديد كرده است. به همين خاطر كار در اين موضع از يك سو هم جنجالى است و هم بسيار ضرورى و از سوى ديگر بسيار مشكل. جنجالى است به خاطر آن كه ما را مواجه با بسيارى از سنتهاى غلط و نادرستى قرار مىدهد كه ريشه در جهالت مردم و اجتماع و تصور نادرست آنان از زن دارد كه بعضى از علما متاسفانه با تمام توان خود از آن حمايت مى كنند و مشكل است بـ به آنه خاطر اينكه احتياج به بررسى عميق روايتى و تاريخى و وان استدلال محكم اصولى و فقهى و همجنين فلسفى دارد.
كى مىتواند نقش حماسه ساز زينب(س) را در نهضت آزادى خواهانه ى حسين(ع) ناديده بخيرد، او كه در مقطعى از تاريخ به اتفاق همة علما، رهبرى بزرگترين قيام اسلامى و ماندگًارترين نهضت تاريخى را بدوش گرفت و با حضور در صحنههاى سياست با شمشير زبان و منطق رساى خود يزيد آن خليفه مقتدر وقت رآ آن مجبور به تغيير موضع نمود؛ جرا در آن زمان كه بسيار نزديك با زمان ريامبر بود، كسى نگفت كه نبايد صداى

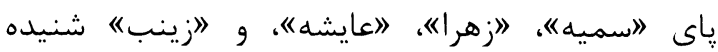

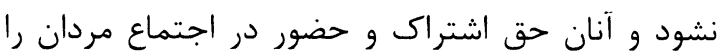
ندارند و مبارزات اجتماعى و سياسى تنها لايق مردان

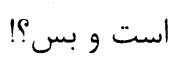
دليلش معلوم است، زيرا ييامبر (ص) همان ديدى را كه نسبت به مردان داشت، زنان را نيز به همان ديد مىنغريست؛ اما تفاوتهاى فزيكى و توانمندىهاى وجودى يى كه مردان دارند، آنها را متناسب با بعضى از فعاليتها ساخته؛ در متقابل در زن نيز توانمندىهايى است كه مردان از آن محروم اند و اين هر زَ دليل بر اين دين نمىشود كه ما انسانيت او رازير سوال ببريم. خداوند وقتى از خلقت انسان صحبت مى كند و بزرگى و توانمندى او را به بيان مى گيرد، از مرد و زن بى هيج تفاوتى نام مىبرد: اانا خلقناكم من ذكر و انثى" ما شما را از يك مرد و زن آفريديه؛ يعنى ريشه شما همان مرد

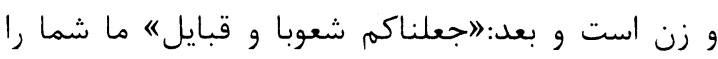
ملتها و قبايل زَردانيديه و از آن اقوام مختلف و مليتهاى گوناگون به وجود آورديم؛ اما آنجه كه باعث امتياز شما است، قوم، مليت و يا جنسيت نيست، از اين نظرها همه يكسان هستيد. اول مسأله شناخت را ييش مى كشد و عنصر معرفت راو سيس تقوا و پرهيز گارى را، و مى زويد آن كه در نزد خدا امتياز دارد، كسى است كه باتقواترين شما باشد، مراعات حقوق انسان و شناخت براى تشخيص مزيتهايى كه انسان را از ملائك بالاتر مى برد،

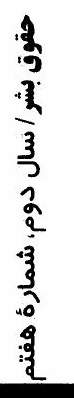

$r$. 
زنان و فعاليـت آنهـا در عرصـهــاى

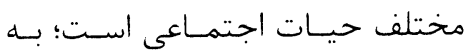
طــورى كسهـ يكـى از دســتاوردهاى بزرگ و قابل عرضهاى كسه حكومـت

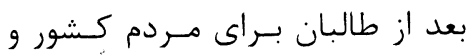

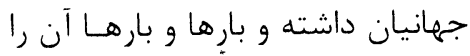

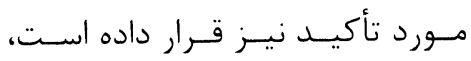

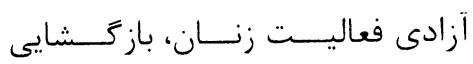

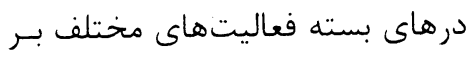

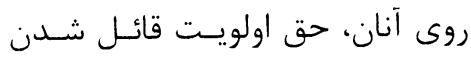

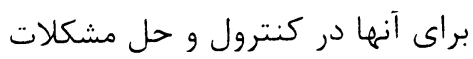
مربوط به زنان، تأسيس وزارت زنسان منحيث يك عملكرد تبعيض مثبـت نه نه

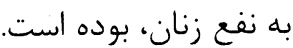

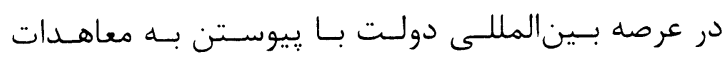

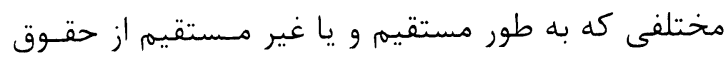

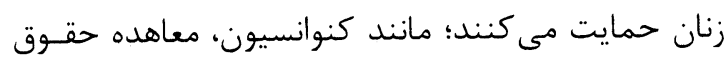

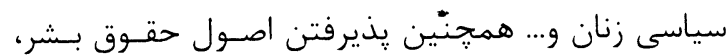

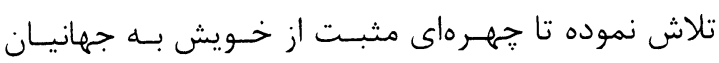
نشان دهد و ثابت نمايد كه به تساوى حقوق زن و مرد و رعايت اصول حقوق بشر پايبند و متعهد است.

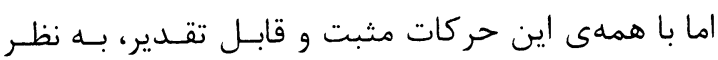

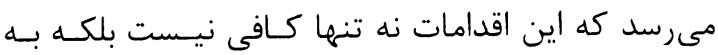

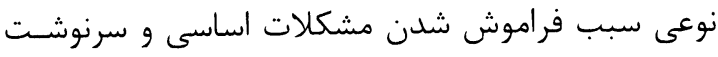

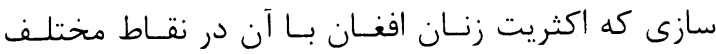
كشور به خـصوص در جوامـع روستـايى و دور افتـاده و نيمه شهرى روبرو هستند، شده است. اين گَونه حركـات

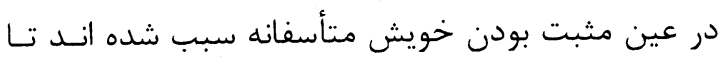
مشكلات رنجبـار و روز افـزون زنـان تحست مُالـشعاع قـرار

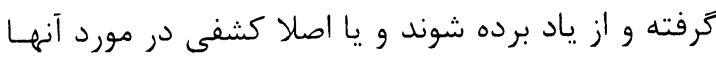

\section{(تأملى كوتاه بر مشكلات زنان افغان)} در هر كجاى دنيا وقتى صحبت از حقـوق بـشر، عـدالت اجتماعى، مردم سـالارى و انسسان مـدارى مسىشـود، در اولين تأمل مسئله زن و حقوق او مطرح مى براى سنجش ميزان گسترش و استقرار دموكراسـى، بـهـ مـــسئله زن، حقـــوق او و ميـــزان مــــار كت وى در فعاليـتهـاى گَونـاگون سياسـى، فرهنكَى، اجتمـاعى و اقتصادى، منحيث يكى از ضرورىترين فكتهـا مراجعسه صورت مى گيرد و وبا شـخص شـدن فيـصدى حسضور در صحنه و فعاليت زنان در عرصـهـهـاى يـاد شـده نتيجـهـ كرفته مىشود كه يك جامعه به جه سـطحى از رشـــ و

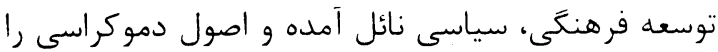
تحقق بخشيده است. در كشور ما نيز يكى از اساسىتسرين معيارهـاى ارزيـابى دهى

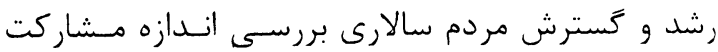


عرصه هاى عمـل اجتمــاعى نهفتـهـ اسـت. واقعيـتهــــ موجود در جامعه ما به عينه نشان مسى دهنــد كـه اكثـر مظالمى كه بر زنان روا داشته مىشوند؛ مانـــد بــد دادن، قتل هاى ناموسى، شكنجه، آزار و اذيت زنسان و خريـد و هـ

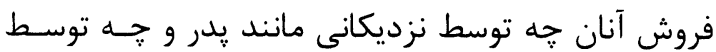
بانـدهاى مافيـايى، تعـدد زوجــات، واداركـردن آنهـا بــهـ كارهاى شاق و اجبـارى، ازدواجهــاى ناخواســه، همـهـ و همه به طور روزمره و عملا انجام مى گيرند. ايـن مظــالم

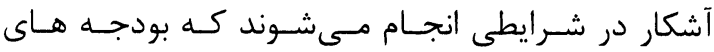

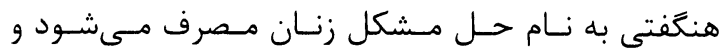
تبليغات ناشى از آن افكار عمومى را فريب مى دهد و بـهـ

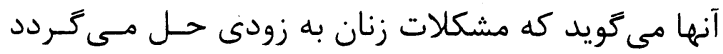

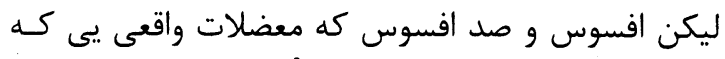

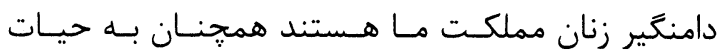

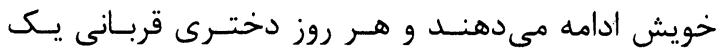

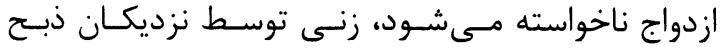

مى گردد و يا طفلى كم سن و سال به عقد يِرمردى و يا لـا زور سالارى در متى آيد و يا ...و يا ...

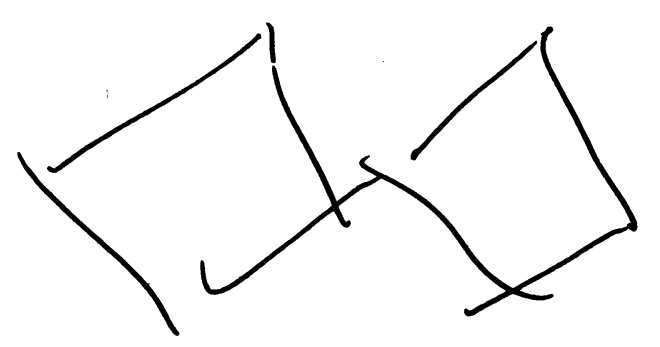

صورت بيذيرد و در سطحى ديكر باعث مىشود كـه كـار

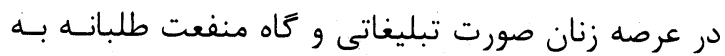
خود بخيرد و. به اصطلاح عاميانهتر كار براى زنان ان جى او يى شده و عدهاى براى يركردن جيبهاى خـويش بـه فعاليتهاى غيرمفيد و بيشتر تبليغاتى دست بزنند.

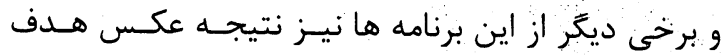
اصلى خود داشته است و به جاى كمك كردن بـهـ زنـان خواسته يا ناخواسته سنبب شـده انـد تـا مـشكلات زنسان بيشتر شود؛ به طور مثال تشكيل وزارت زنان بـهـ منظـور

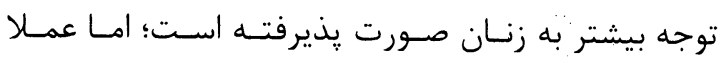

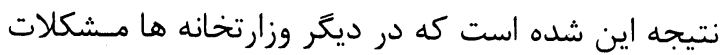
زنان حل نشده و به وزارت زنان ارجاع داده شود. اين در

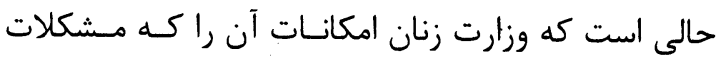
همه زنان را در همه جا مرتفع بسازد، ندارد و مسىبينسيه

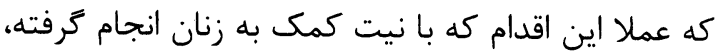

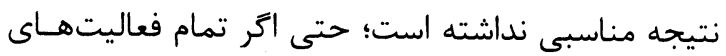

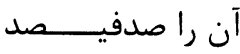

موفقيت آميز تلقى نمائيه.

برخلاف آنجــهـ كـــ

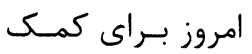
به زنسان و بـهـ نـام آنان انجام مىشود

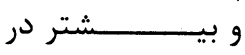

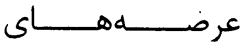
تبليغاتى و تيوريك اســت، بـــه نظـــــــ نغارنــــه مــشكل زنـــــان نــــــه در عرصـهـــاى يــاد شـــده؛ بلكـــهـه در
برخلاف آنجه كه امروز براى كمك به زنان و به نام آنان انجام مىشود و بيشتر در عرصه هاى تبليغاتى و تيوريكك است، به نظر نكارنده مشكل زنان نه در عرصههاى ياد شده؛ بلكه در عرصههاى عمل اجتماعى نهفته 
口 امان الله موسا

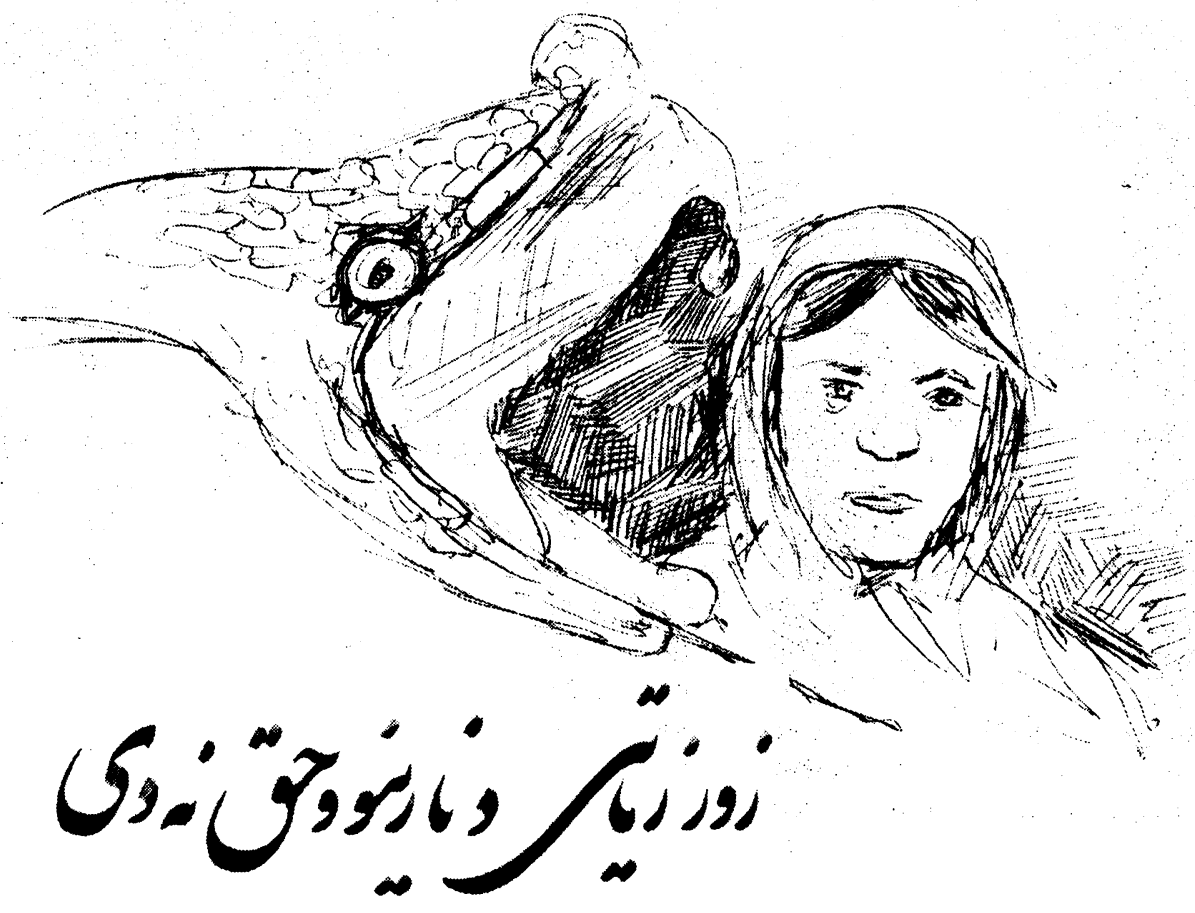

انسانان دنيا ته ازاد راحي، او د باكى خسداى ج يـه حضسور كى مساوي حقوق لـري، او تولنه اره ده حي دغه حقـوق مراعات كري او خوكى يرى نبودي خي دبل خحا حقوق تبر بِبنو لاندب كري. كله بجي يو خـوكى د انسـان كليمه كاروي نو دهغه خخخـه مطلب نارينه او بنحينه دواره

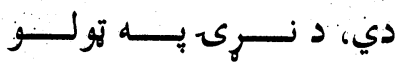
فرهنكونو كي د انسان كليمه

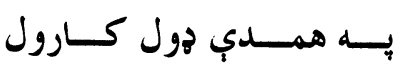

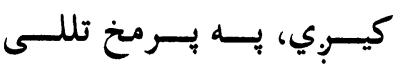

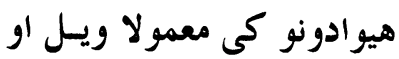
كول يوشانى مانا لري خو د بده مرغه يه وروستسته يـاتى هيوادونو كي جي جيريب مترقى فرهنك ته احترام نه لري نو يه ديرو وختونو كي به خبرو باندى لو بـى كيسبوي او

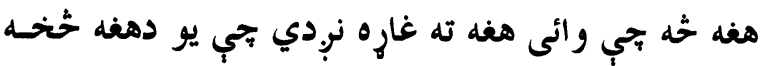

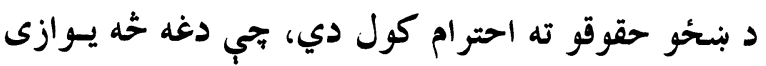

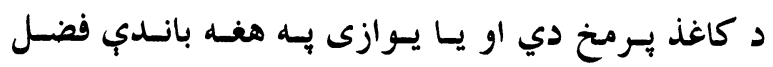
فروشى كوي، خو به عمل كي بنحخى د نارينور دخوبنى.

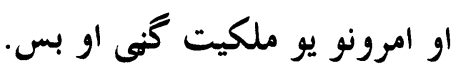

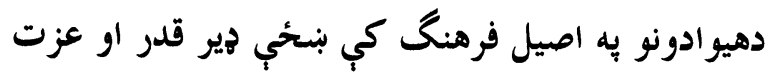

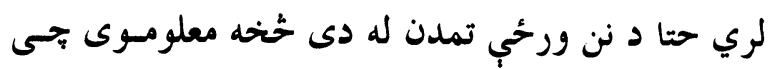

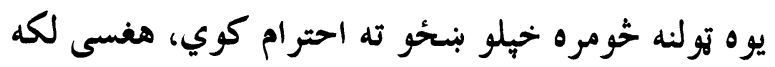
هير ارويائى فيلسوفان يه دى بانسدي تينگـار كـوي جهي محترم نارينه هرو مرو دبنسخى لور مقام ته احترام كوي، لئل

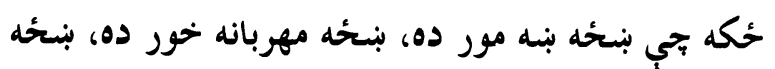


مرى سـره يسه لر خيسو كي كبنسينوله او بيـا بسه يسي اور وراباوه، خو كه بجيسري بيـا د يسوه سـرى ميسرمن مسره كيده، نو نارينه حق درلود جي د بلى بنسحئ سـره واده وكري، دغه مضمون زموبٍ د بِبنتو لورخيـالى فيلسسوف او شـاعر خوشـال ختهك يخيـل يـوه شـعر كـي داسـى

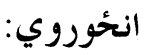

لكه زه بِه يارمين يم بل به نه وى مين هسسى

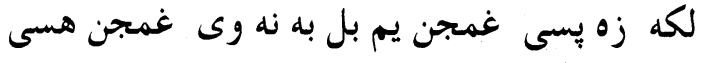

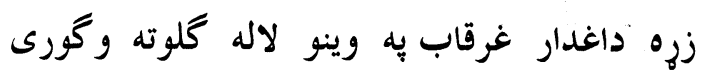
هيخ شهيد راورىى نه دي له ازله كفن هسى كه يب رسم يا كه دود دى يا وفا د هندو كيه جي د ياره سره سوحي خو ك به و كا سوختن هسي

له بده مرغه زموبر بـه هيسواد كي هـم د وروسـته بـاتى فرهنك نبنى شته او دير نارينه بِ دى فكر كي دي بـي نارينه له بنسئو نه لور مقام لـري، نارينسه د ذيسرو شـيانو حقوق لري، خو هغه حقوق بيا بنـحئى ته نه وركوي، شته داسى بنسـتّ يالسه جـي د نجونسو بنسوونحئي سـوحي او نجونى به دى ويروي بجي بنوونحيوته ولارى نشي نجي دغه كار د بنسحو يه مقابل كي لـوى زور زيساتى دى، يسه داسى حال كي تجي يوهـه ((علـم)) يرنارينسه او بنسـينه باندي فرض شوى دي، بنحُه بتي يوه او عالمه وي له نا

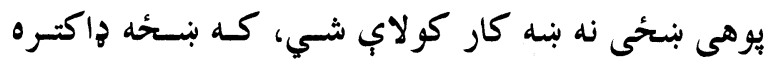
وي، نو د ناروغو بنحخو خدمت كولاي شي، كـه بنسـحة يوليسه وي نو د بنسئو د حقوقو مدافعه كولاي شي، كه بنحةه قانون يوه او يا قاضي وي د مظلومو بنححو حقوقـو ورته اخيستلاى شي، كه بنسحة ليكواله او يا هـم شـاعره وى نو يخهيلو مضمونونو او شعرونو كي دبنسحو درد او نازك خيالى بيانولاي شي، دا تول شيان هله امكان لري
كي يو متل وايي((اولاد به بي بِلارى نه خواريبوي خو بيه بى مورى خواريبِي)(

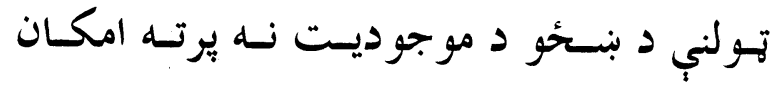
نلري، بنحُحه كه يه يوه حُّى كي مهربانسه مسور ده يسه بـل حــاى كي وفـاداره ميسرمن ده، يسه يوحُاى كى خدمتكاره خــور ده، يسه بـل حــاى كـي مهربانــه موســتندويه ده، دا تهـول هغــه و اقعيتونه دي جي ستر گى ترى يتيدلاءي نشي،

د هيخ هيواد تساريخ نشـته بــي د بنسـحو د قهر مـانيو او

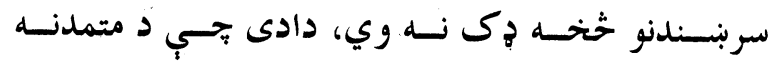
هيوادونه فرهنگ د بنسحى لـورة مقـام تسه بـه ربنستيا سـر تيتوي، خو برعكس يه وروسته ياتى هيوادونو كـي دغسه

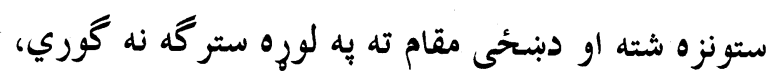

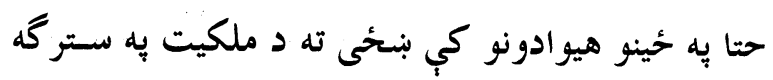
كورى، نو دادى جي بِ دغه شان فرهنگ كي دي دو لونو بيه زيويدلو سره يه كورونو كى خوبنسنى نسه وي، بـرعكس

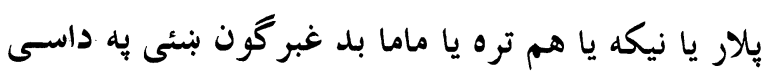
حال كي جي د دوى تولو د زيجوولو واسطه مور ده. هر خومره تجي د يو هيواد فرهنگ متمدنسه او عـالى وي يه هغه سويه د بنحتو د مقام قدر كيوب، هر خومره بـي د يو هيواد د فرهنك وروسته ياتى وي، يسه هغسه انسلدازه بيا بنحَه د نارينوو يه خحمت كي وي او احتسرام يسي نسه كي.ري، كسه مسوبٍ د هندوسـتان بِحسوانى تساريخ تسه نظـر

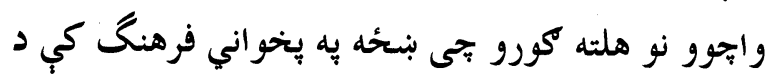
ملكيت به تو گه وه نه د شخصسيت، هلتسه كلسه بـي بسه نارينه(ميره) مر شو نو دهغه ميرمن به يي زُونـدى دده د 
و اقعيتونه دي جي ستركى تسرى يتيسلاي نشسي، او كسه خو كى ترى ستر گى بتّوي كوا كى شحان تير باسي. بنه نارينه او بنه ميره هغه خوكى دى جي دخبل ميرمنى احترام و كري او خهلو لونهو تسه د زامنسو يسه خيـر قـدر اوعزت وركري او يه مينحُ كى يب تويبر ونكري.

د بشري حقوقو له يلوه بنححه او نر دواره يو بشر دى، دغه كليمه د باكى خداى(ج) يه قـانون كک دواره جنسونو ته يو شان كارول شويده، نسو آيـا كومه بله بلمه شته بجي نارينسه د بنسـحَى نسه لـوروو بولو مكر دخيل علم او اخلاقو له يلوه.

هر خومره هي د انسان ير فكر حيوانى غريزه غالبه وي يه هغه اندازه تاو تريخوالى كوي. بر عكسـ متمــدن او عالى انسان تل مشفق او مهربانه وى، حوصله لري، خوا خوبِى لري، الفت لري، صسميمي وي، او اولاد دوسسته
جي بنحي بنوونتحيوته ولاري شي او به علم باندي خهيل فكر سمبال كري، يه دى شان به دوى هم عالى شسي او لهري

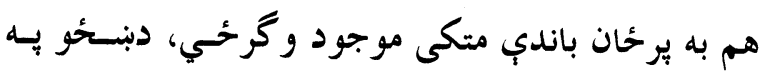
مقابل كى د زور زياتى ستونزه نيوه جدى ده بـي بايسد كلكه بِاملرنه ورته وشي، حتا بِ برمخ تللو هيوادونو كي

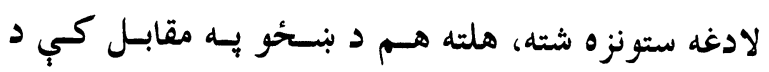
تعصب او دوه رنكى خخه كار اخيستل كيب.ي خود شدت درجه به يي تر وروسته باتى هيوادونو لجِه وي. د بشري حقوقو له يلوه بنسخه او نر دواره يسو بشـر دى، دغسه كليمسه د بـاكى خسـداى(ج) بـه قـانون كـي دواره جنسونو ته يو شان كارول شويده، نو آيا كومه بله بِمه شته بحي نارينه د بنسحى نه لورو بولو مخر دخبل علسم او اخلاقو له يلوه.

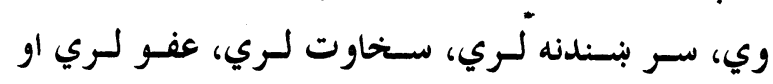
يرعزت نفس غالب وي. هيخ نارينه بايسل يخهيـل تـاوتريخو الى او زورزيساتى سـره دخهيلى كورنى خوبِ زُوند تريخ نسه كـري، بنسحة خحانتسه

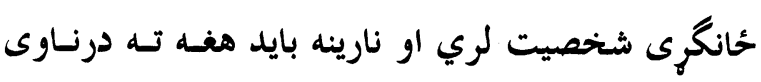
وكـري، هفسومره جسي مهربسانى او صسميميت كسار بنسه كولاي شي، تا وتريخوالى او زورزياتى يب نشب كولاب، نو حيكه وايو هجي زورزيساتى او تـاوتريخو الى د نسارينوو

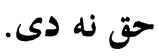


آنها گوش داده باشد و كارى كرده باشد تا آنها از حداقل حقوق اساسى و امكانات زندگى بهرهمند شوند.

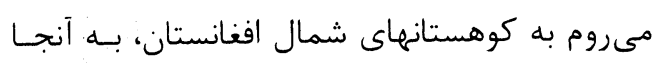

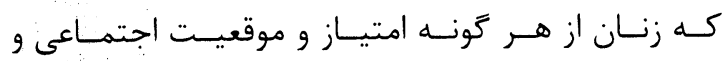

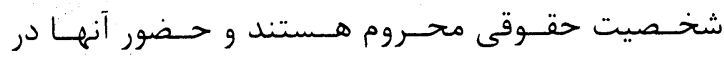
اجتماع، بى غيرتى مردان بهحساب مى آيد. زنان بايـد در

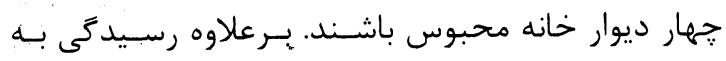

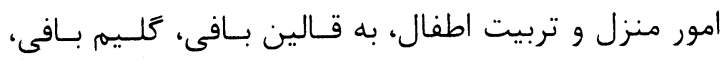

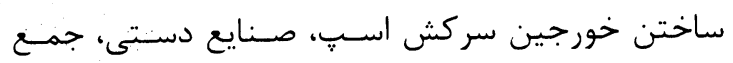

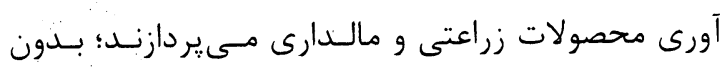
آن كه كدام امتياز مادى و صلاحيت مصرف داشته باشند.
تاريخ زنان افغان مملو از حوادث تلـخ و غـم بـارى

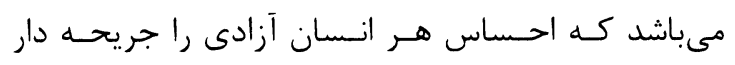
مىسازد. شرايط زندگى آنها هموار. نامساعد بـوده اسـت.

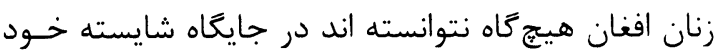

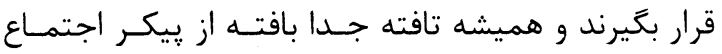

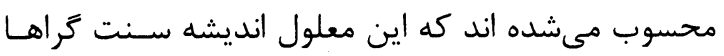
در جامعه كاملا روستائى، قبيلوى و به شـدت مردسـالار مَا مىباشد.

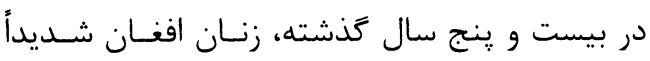

دجار بحران هويت و شخصيت حقوقى بوده اند كـهـ دوره جاهليت قبل از اسلام را در اذهان تداعى مى كند. بعد از

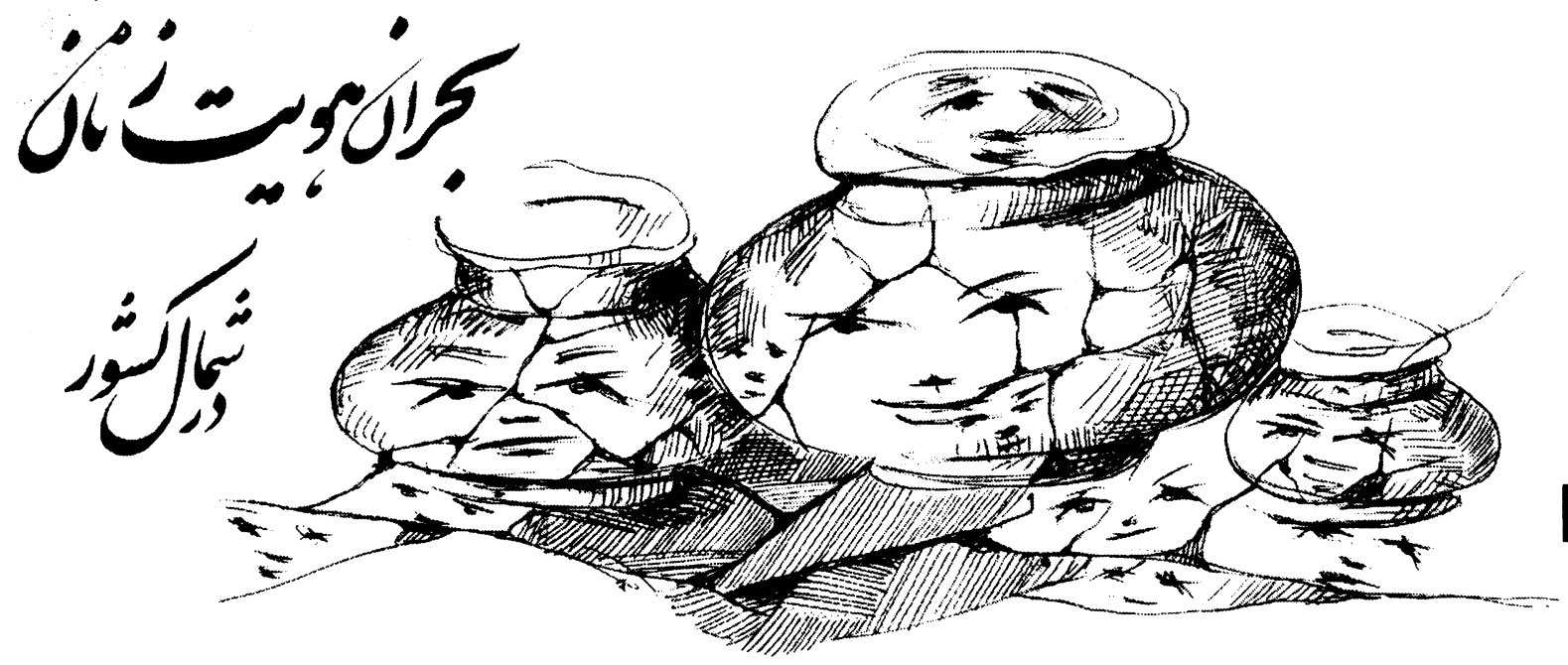

\section{بان}

در بلخاب كه يكى از محسـروم تـرين ولـسوالىهـاى

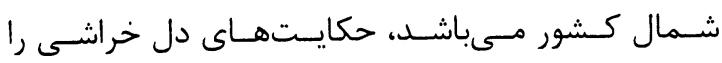

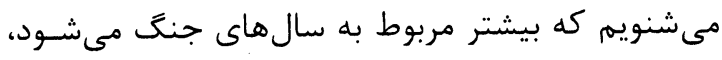

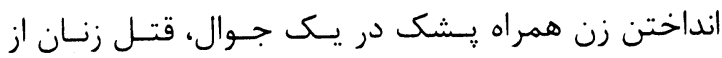

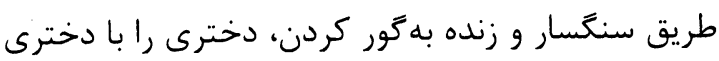

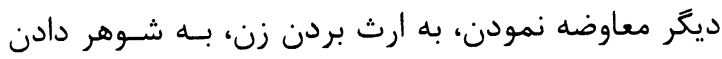

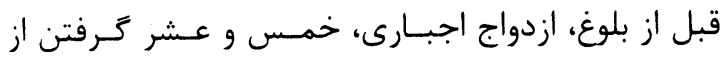

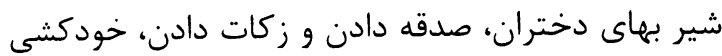

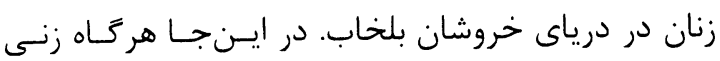

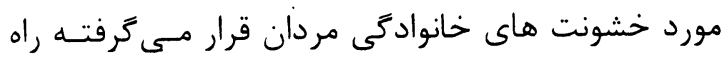

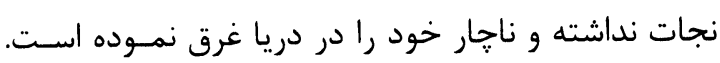

سقوط طالبان و آغاز دور جديدى از تـاريخ كـهـ موضـوع حقوق زن از اساسىترين موضـوعات مـسائل افغانسستان شمرده مىشود، سازمانها و تشكيل هاى زيـادى در دفـاع از حقوق زن ايجاد گرديّد اما ديد تحقير آميز و خــشونت عليه زنان و باورهاي ويرانگر نسبت به زنان جندان زئ تغيير

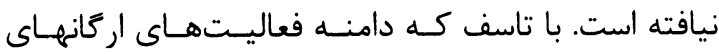
مدافع حقوق زن از دروازههــاى شـهر بــه طـرف دهــات ييشرفت ثبت نكرده و به ندرت مسشاهده مسى كـردد كـه لهـ كسى به قريه جات دور دست و اطراف رفته باشد و براى

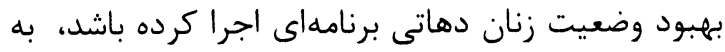

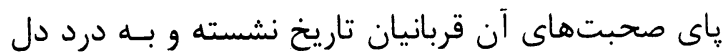


زنان تونج و اندراب وضعيتى بهتـــ از زنــان بلخـاب

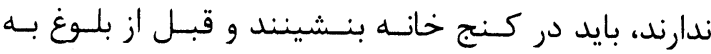

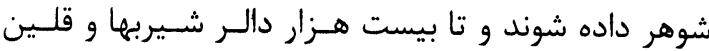

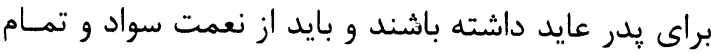

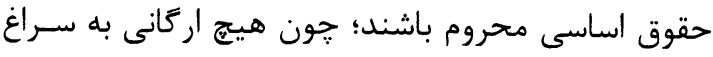

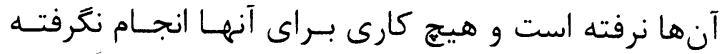

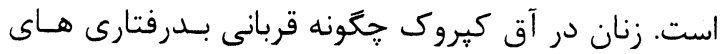

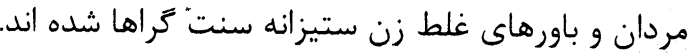

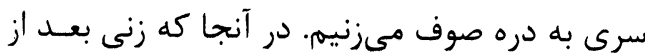

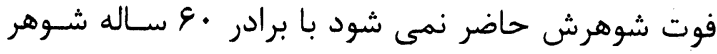

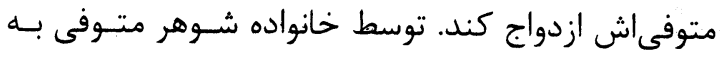

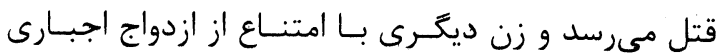

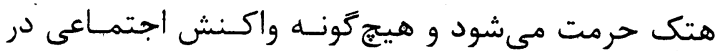

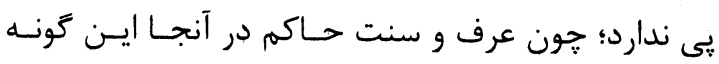

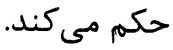

براى زنان دره صوف كلينيك نسائى ولادى وجـود

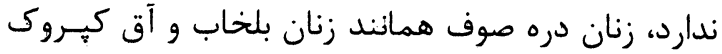

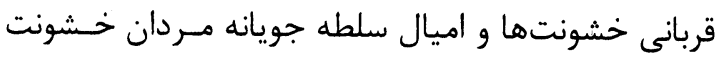

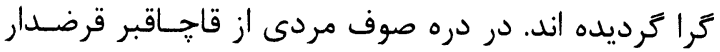

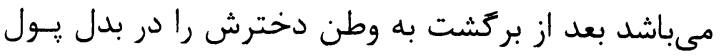

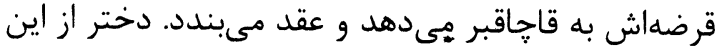

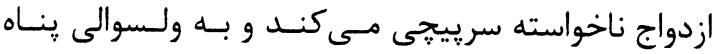

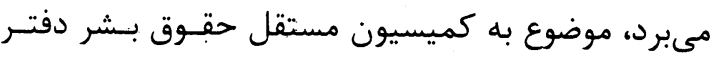

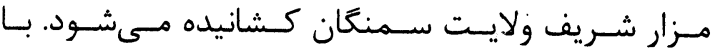
يشتيبانيى ولسوال دره صوف قضيه به نفع دختـر خاتمـهـ

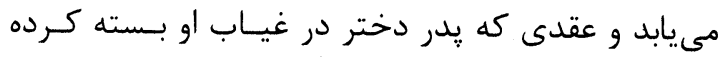

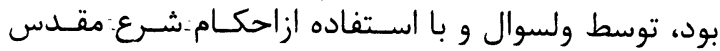

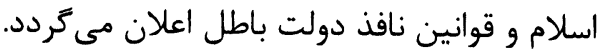

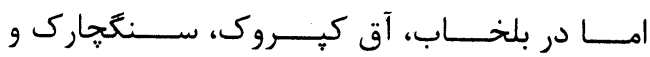

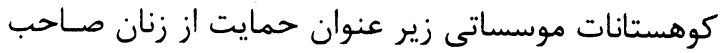
نان و ثروت شده اند ولى كارى براى آنها انجام نداده اند.

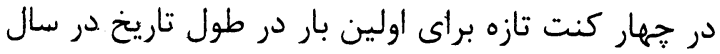

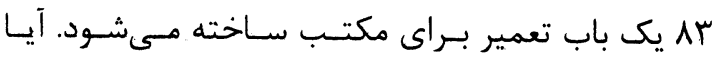

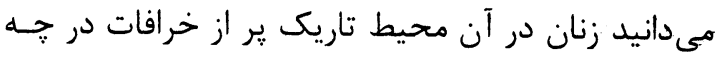

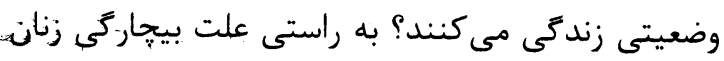
در كوهستانهاى شمال جه مى زباشد.

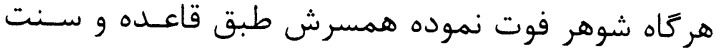

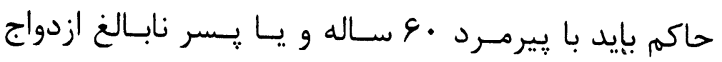

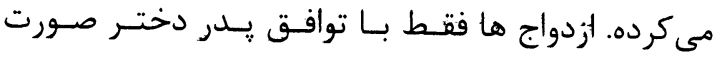

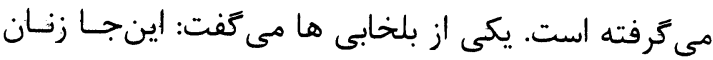

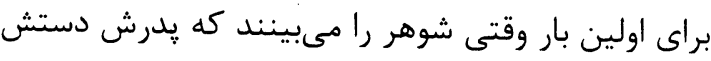

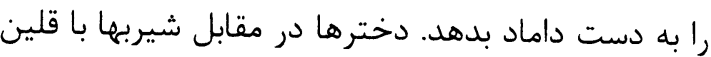

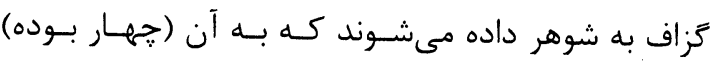

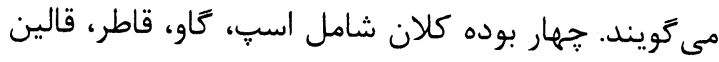

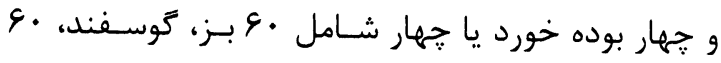

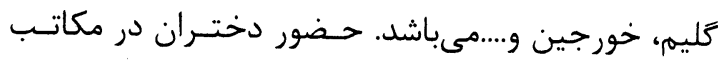

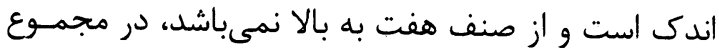

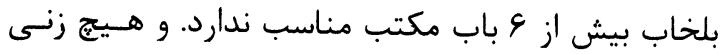

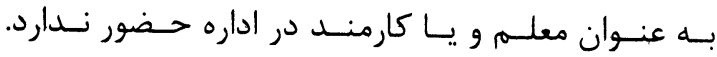

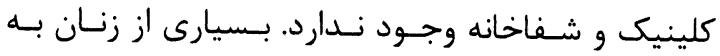

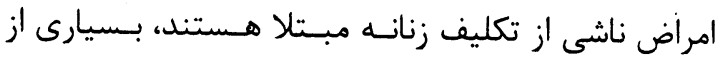

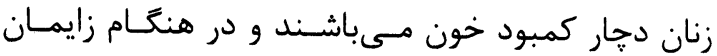

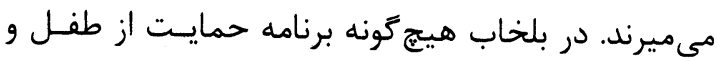

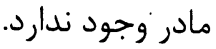

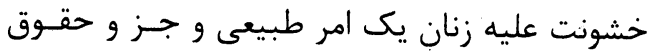

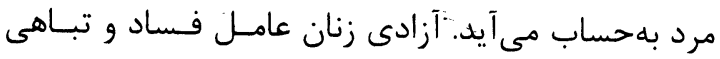

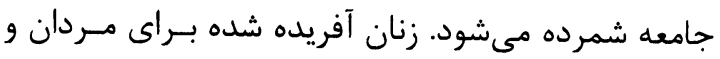

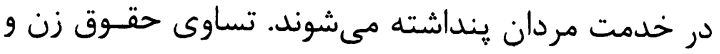

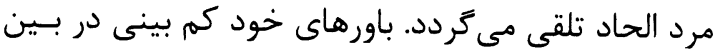

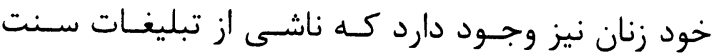

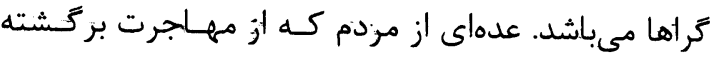

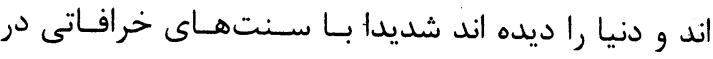
مبارزه هستند. از اندراب و تونج در مربوطات ولسوالى آق كيـروكى

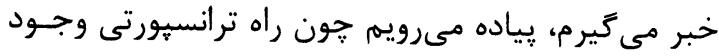

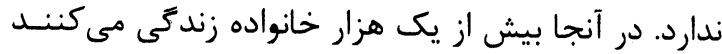

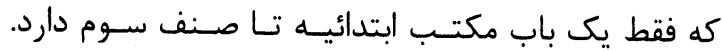

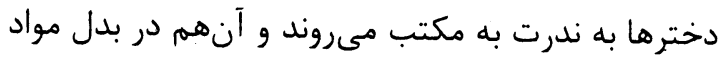

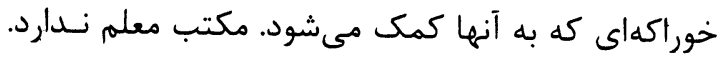

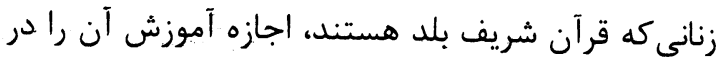
مكتب براى شاكردان ندارند. 


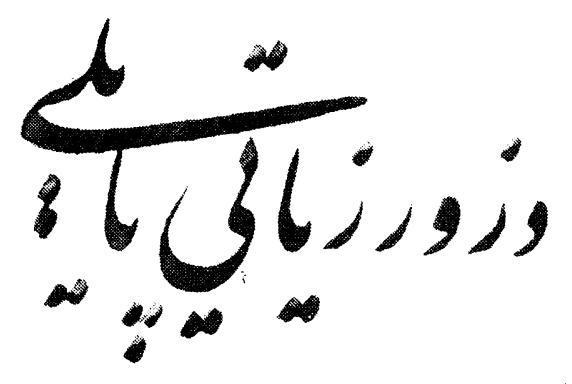

نه هم بب برخي دب او نيوهيوبي بتي اسـلام ورتسه كسوم حق وركري دى. ץ-دوهم لامل جبري ودونه دي بـي بسه دي كسي هغسه ودونه رائي تي يا د بدو يا د بدل بربنسستّ شسوى وي يا دولور ناوره اغيزه بري لويدلي وي او يا دنسور نساوره دوديزو رواجوو زيونده وي. به دغه دول ودونو كي د خبنتن او ميرمن خوبنه به نظر كى نه نيول كي.ي د بيلكي بِ تو گه كه كوم و اده د بدو بربنست وشي، نه د بنسحى خوبنسه، نه د خحاونسد او نسه د كورنى خوبنه بِه نظّر كي نيول كيوي بلكي د دبنسمنى د ختمولو لياره د يو مصلحت ليـاره تـر سـره كبـري، نسو

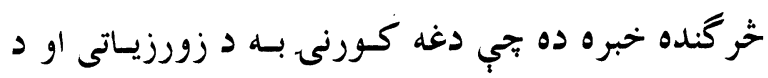
تاوتريخو الى به لمبو كي سوزي. هغه خو ب بي د ولور د بريكولو وس نه لري نو بدل كوي يعني خيلي لورگًاني

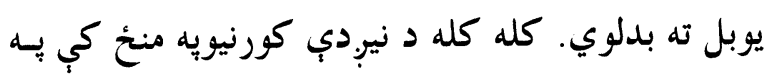
دوديزه تو كه هم دا كار كيري. خو له بده مرغه بجي تومر گه بوري د دوي سـره د د بـدل به تو گه جلند كيبِي كه ديوب سره بنه سلو كى كيوي، د بلي سره به هم بنسه سـلو ك كيسبِي، او ديسوب سـره بسد سلوك كي.ي، نو بله به هم د بد سلوك سـره مخـامخ كيبِي، كه به يوي بانسلدي خاونسل بلـه بنسـحه راولهي نسو دوهمه كورنى بسه خيسل زوي تسه بلسه بنسحة كسوي. نسو

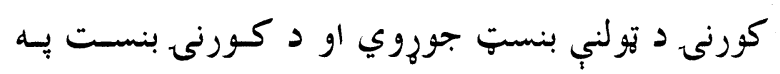
ميرمن او خَبنتن ولار دى. كه د كورنى بنستز نه سم نسه وي نو د دوى نا سمو الى بر تولنه خيله اغيزه شيندي. دا بايد هيره نكهو تجي د كورنى اغيزي برتولنه او د تهولني

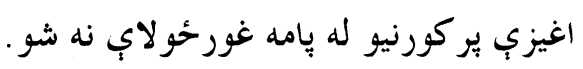
يه كورنى كي دُ زور زياتى او تا وتريخو الى لا ملونه كه بِه ميرمن او خاوند كي هم وي سرجينه يب بايد به ترلنسه او د تيولني به جوربنست كي و خيرل شي. د زور زيساتي

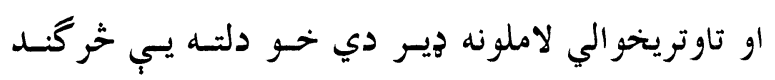
لاملونه تجي زموبر تولنه ورسره مخامخ ده به كوته كوو . 1 -دليك لوست نه، د تولني د ديسري غريسو بسى برخسه كيدل او يا يه تزولنه كي د ليسك لوسـت كمبنست، لـه

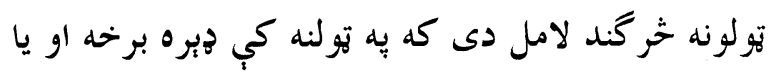

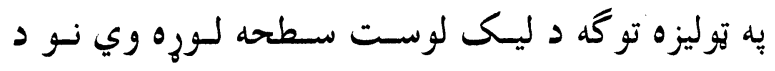
كورنى غري به د يوبل به حقونو بوه وي او د يو بل حق ته به غاره بِدي او د يوبل به حق به تيري نه كوي. خسو

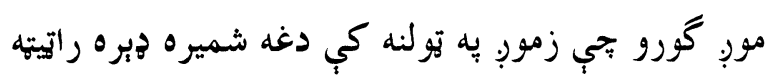
ده او به نارينه وو كي هم د تامل ورج ده، يه ميرمنو كي خو دغه شميره بيا د نشت يه حساب ده. نوخنكه كيداب شي تجي يوه ميرمن خيل حست وغـواري؟ كه د رسمى تعليماتو نه راتير شو زمسوبٍ د تهولني ذيسرى غري بنححه ده او كه نارينه د دينى زده كرو او تعليمـاتو 
خوبنه عملى نه شي، نو هوومرو تيكرته زمينسه برابريسب. او تاوتريخو الى رامنح ته كوي. د زورزياتى او تاوتريخوالي به هكله يسورتني خولاملونسه خر گند شول تجي له لفظى جكئي نه نيولى بيسا تروهلسو،

$$
\text { زورولو او حتى تروزلو بوري رسيربي. }
$$

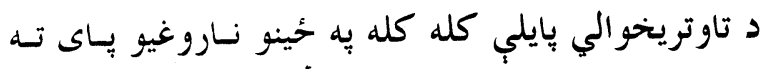

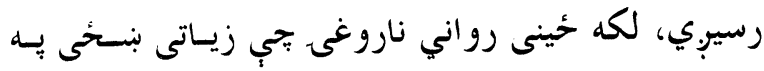

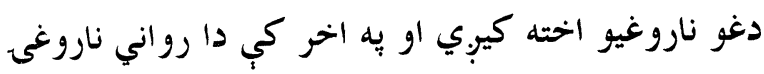

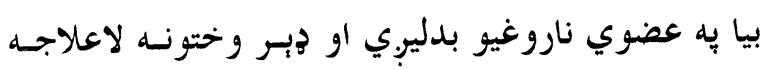
وي. همدارنگه زور زيساتى او تساوتريخو الى د امينسدوارى يسه وخت كي ناوره اغيزي لري، لكه د ماشوم سـقط او بـهـ

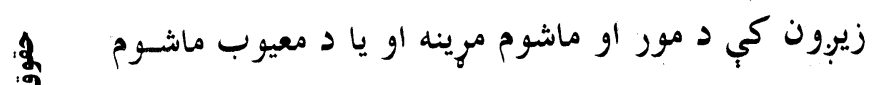
زيوبول او داسي نورى ستونزى. همدارنگه كله كله ددغه زور زياتي او تا وتريخو الي لـه نه كبله بنحته انحر اف كوي يا خحاني وزني يسا تبنستى او يـا

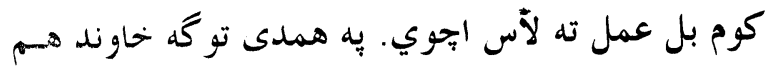

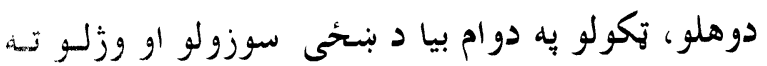

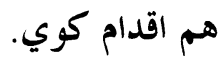
به دى تو گه ويلى شو تجي د د زور زياتي او تاوتريخو الي بايلب دُبري ناوره دي، د كورنى بنستونه كمزورى كوي

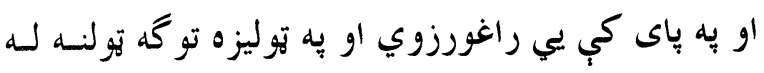
بيلابيلو ربرو او ستونزو سره مخامخه كوي.
خر گنده خبـره ده

جسي د بــدل بــر به كورنى كي د زور

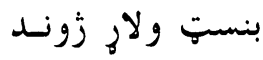
د تســـــاوتريخو الى لى خخه ركى دى.

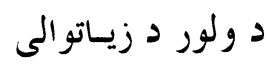
لـه كبلسه هـم يسه كورنى كي زيسات

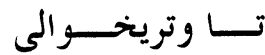
زياتى او تا وتريخو الى لا

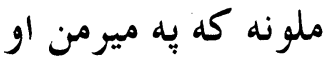
خاوند كي هم وي سر بحينه يب بايد يه تر لنه

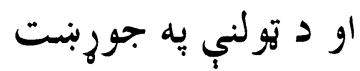
كي و خيرل شي.

رامنخ ته كيوي او

خومره جي ولسور زيساتيوي، هغسومره ورسـره كسورنى د اقتصادى ستونزو سره مخهـامخ كيسبوي، او خـومره جسي

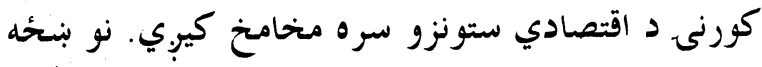
بيا د زورزياتى او ناخو الو سره مخامخه كيوي.

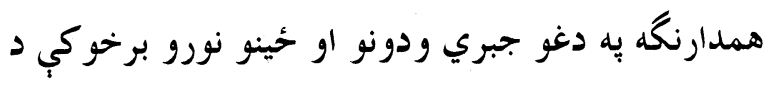
عمر توبير هم ذبرب ستونزب رامنحُ ته كوي. بـه جبـري ودونو كي د بنسخي او خحاونسد تـر مسنـخ د عمسر توبيرتسه

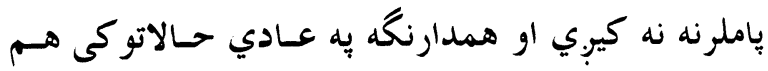
زمور. تولنه د دي اصل دومره يروا نه ساتي. نسو دبنستي

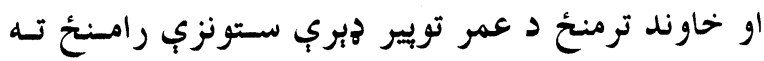
كوي حئه تجي د دوي غوبنتنى، د فكسر لاره او نسوري

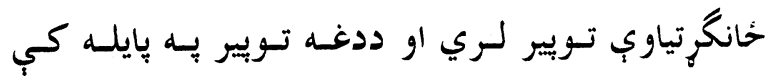
تكرومه رامنحخ تسه كبهبِي او بيسا د تسا وتريخسو الى لامسل كرخي. همدارنكه به دوديزه تو گه د بنحتي او خاوند بِه كـورني

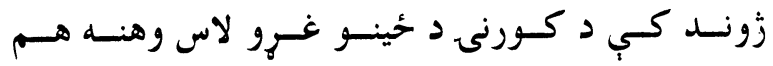

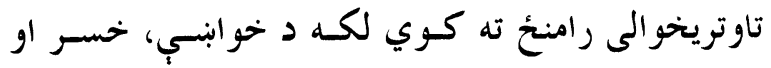

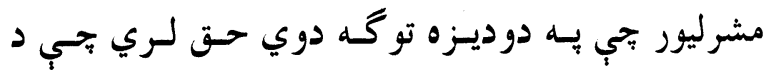
بنسخي او خاوند به زُوند كى گوتي ووهي او كه د دوي 
طفل، مصوب مجمع

عمومى سازمان ملل متحد

در 1919 در

الاعلاميه جهانى بقاء، رشد

و حمايت از اطفال، مصوب

اجلاس شمران دولت ها

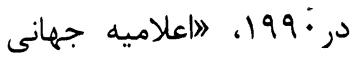

حقوق بشر، مصوب I9F1

مجمع عمومى سازمان ملل

متحد در • ب مادهب، صورت

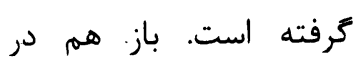

بسيارى از موارد، مورد ظلم

و تبعيض قرار ميىيرند و وأر مورد

شأن انسانى آنها رعايت رئرند

نمىشود.

در اين مقاله، بررسى حقوق

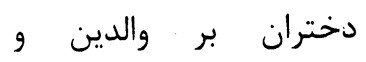

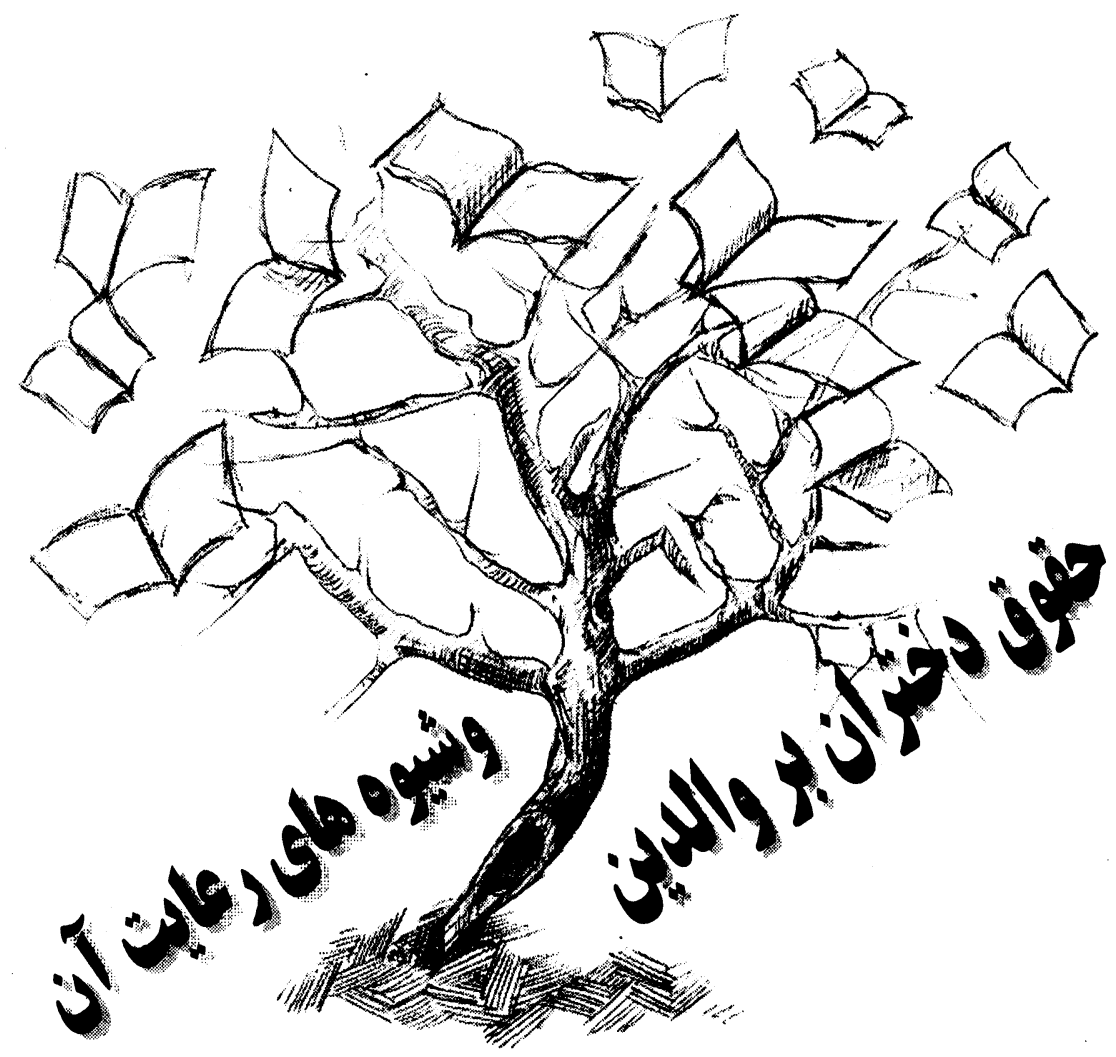

شيوههاى رعايت آن مد بد بر

نظر بوده كه تاكنون يزوهشى در اين مورد به طور

مشخص صورت نيافته است. در اين جا قبل از اين كه به

口 هوهنمل عبدالحق

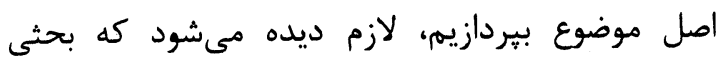
ييرامون ارزش و مقام دختر از ديدگاه دين مبين اسلام

داشته باشينم.

موقف دختران از ديدكاه اسلام

اگر امروز مىبينيم كه حمايت از دختران و فراهم كردن زمينههاى مساعد براى رشد همه جانبه آنان و شعوفي

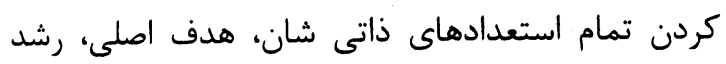
آنهاست، در قرون حذشته اين جنين ديدگاه هايى كمتر به جشم مى خورد و به دلايل مختلف والدين، دختران شان را از بين مىبردند؛ به عنوان مثال در شبه جزيه دوره عربستان و قبل از ظهور اسلام زنده به گور كردن دختران امرى طبيعى قلمداد مىشد. قرآن كريم حالت

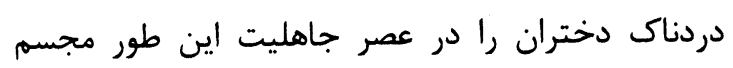

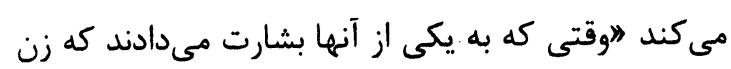

امروز يكى از مسايل مهم و مورد توجه جامعه بين

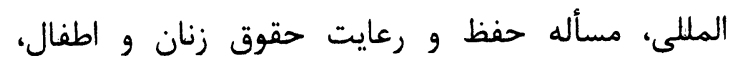
بخصوص دختران و مراعات تساوى حقوق آنها با يسران و عدم تبعيض براساس جنسيت است. اين احساس مخصوصا از آنجا نشأت كرفته است، كه در طول تاريخ، به دختران كه مادران آينده و بخشى مهمى از جامعهاى بشرى ما را تشكيل مىدهند ستم روا رفته، حقوق و وانه

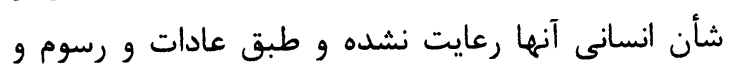
اعتقادت و قوانين و مقررات در مورد آنان تبعيض ناروا اعمال شده است و حتى در دوران كنونى نيز با همه ييشرفتهايى در زمينه رعايت حقوق آنان نظير الاعلاميه جهانى حقوق طفل، مصوب مجمع عمومى سازمان ملل

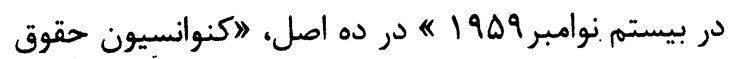


داده اند؛ جنانجه در حديث شريف مىفرمايد:" بهترين فرزندان شما دختران انده. براى تأييد و تثبيت حقوق دختران و تشويق مردم به نتهدارى آنها، رسول خدا مىفرمايد:" هركه مصرف و نفقه سه نفر از دختر و يا خواهرانش را بدوش بخيرد، بهشت بر وى واجب است.

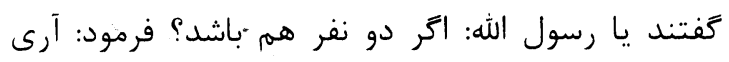

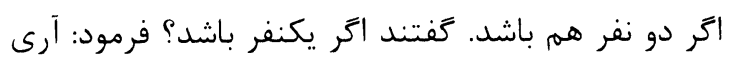
اخر يكنفر هم باشد.

همجنين در روايت ديخرى آمده است: لاهركس كه داراى سه دختر يا خواهر يا دو نفر از آنها باشد و به خوبى آنها رفتار نمايد و در مورد شان به وظيفه خود عمل كند، به بهشت خواهد رفت. از انس (رض) روايت است كه ييغمبر خدا فرمود كه: كسى كه سريرستى دو دختر را بدوش گيرد تا اين كه بالغ ₹ردند، در روز قيامت مى آيد در حالى كه من و او مانند اين دو مىباشيمى و انگگتان خود را با هم يكجا نمود.

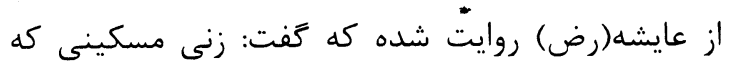
دو دختر را در بغل داشت نزدم آمد من كه دانه خرما برايش دادم و او براى هر يك، يك دانه خرما داد و يكدانه را به دهن خويش نزديك نمود تا آن را بخورد، دخترانش آن را از او خواستند، او آن خرمايى را كه مىخواست بخورد، در ميان شان دو قسمت نمود. من از

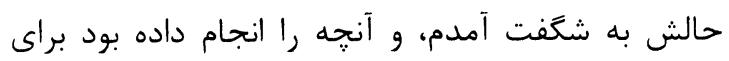
رسول خدا يادآور شدم. آن حضرت(ص) فرمود: خداوند در برابر إين عمل بهشت را برايش لازم ساخت. بادرنظر داشت آنجه كَفتيم، اكنون مىبينه كه يس از حذشت قرنها تازه، دنياى بشريت متوجه شده كه دختر هم مانند يسر انسانى است كه از مزاياى زندگى بايد متمتع گردد و از حق و حقوق خويش بهرهمند شود. بدين ترتيب مىبينيم كه همان طورى كه يسران
او، دختر به دنيا آورده است، جههره اش از شدت ناراحتى سياه مى گشت. در حالى كه خشم خود را فرومى نشاند و خود را از مردم ينهان مىكرد، به خاطر خبر بدى كه باو

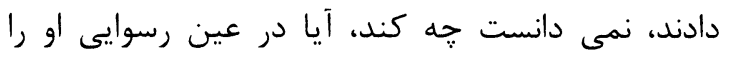

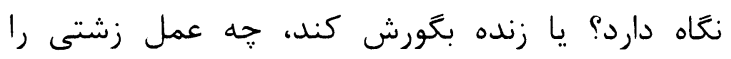

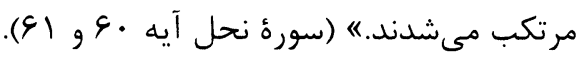
با آمدن دين مبين اسلام، اين عادت زشت شديدا ممنوع گشت و تعاليم اسلامى عاليترين نوع توجه را، به طفل بخصوص دختر مرعى داشته است. جنانجه يِيغمبر اسلام حضرت محمد(ص) بهترين حق را به دختران قائل گرديده و در عصرى كه دختران از مزايايى انسانى و حتى از حق زندگى محروم بودند، آنان را از حقوق شان برخوردار ساخت. از حمزه بن عمران روايت شده است كه مردى حضور رسول خدا آمد، نزد ييغمبر شخصى ديغرى نيز بود، تازه

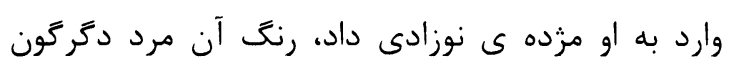
شد. يِيغمبر فرمود: جه شده؟ آن مرد كَفت: از خانه بيرون آمدم در حالى كه زنم دجار درد مخاضن بوده، به من خبر رسيد كه او دختر به دنيا آورده است. ييغمبر فرمود: زمين او را نعاهدارى مى كند و آسمان بدو سايه مىافكَند و خداوند به او روزى مىرساند. حديث شريف است كه: اهنعامى كه بشارت تولد بى بى فاطمه (ع) به رسول خدا داده شد، آن حضرت نگًاه كوتاهى به رخسار اصحاب نموده و در جهره شان آثار ناراحتى را مشاهده

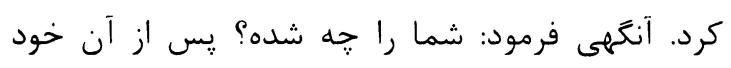
حضرت فرمود: ااين نوزاد دختر همجون شاخه گلى است كه او را مى بويمم و روزى وى را خدا مي رساند.ش

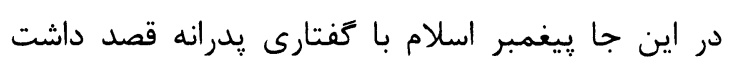
اين عقيدة اجتماعى را تغيير بدهد كه يسر را قابل قبول تر از دختر مى دانستند. ييغمبر حتى از اين هم فراتر رفته و در كفتار ذيل دختر را از يسر مورد توجه قرار 
اين كه دامنه حق دختران تا جه حدى وسيع است،

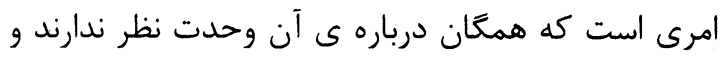
هم اين حق تا جه سنى براى دختران مطرح است،

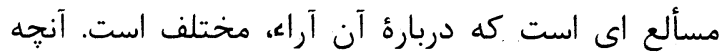
كه ذيلا ذكر مىشود شامل مجموعه اى از نظريات و بينشهايى است كه در اين زمينه وجود دارد.

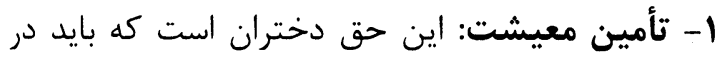
زمان طفوليت و نوجوانى و تا يايان تحصيل و يافتن كار،

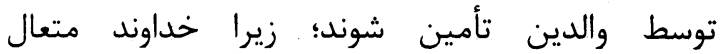
مىفرمايد:ابر كسى كه فرزند از آن او مىباشد (يدر)، واجب است به شيوه اى يسنديده، مخارج (زندگى)،

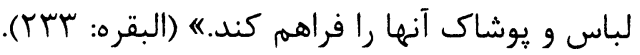
همجنين از يِيغمبر اسلام روايت است كه مئفرمايد: "كسى كه داراى دخترى است؛ اگر او را تغذيه كند و در

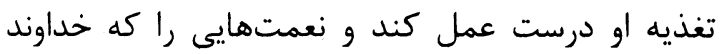

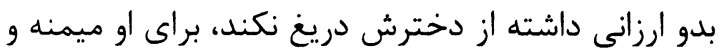

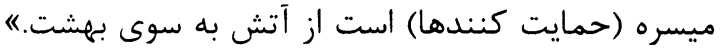
تأمين غذا، لبّاس و مخارج تحصيل، درحد توان، بر كران والدين واجب است و نيازهاى دختر بايد در حدكفايت برطرف شود. والدين وظيفه دارند از غذاها و ميوههاى فصل براى آنان فراهم آورند.

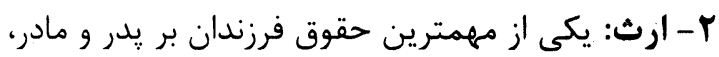
حق ارث بردن است. اين حق، حق اجبارى است و هيج اريج

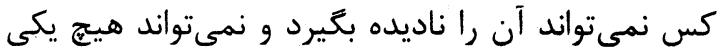
از وارثين را از سهم خود محروم نمايد. هركس كه يسران را بر دختران ترجيح دهد و آنها را آ از ميراث

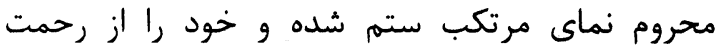
خداوند محروم گردانيده و كارى مشابه كار مردم عصر جاهليت است كه برخى از آنها دختران خود را زنده به كور مىكردند. يديده اى كه در ميان برخى از جوامع رواج يافته است كه دختران را عملا از ارث محروم
حقوقى بر یدران و مادران دارند، دختران نيز بر

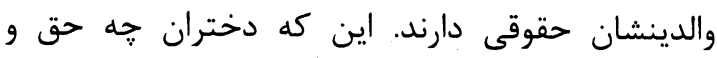

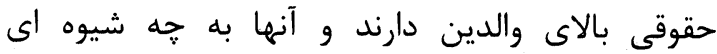

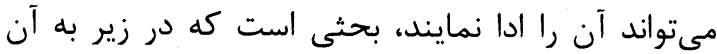
يرداخته مىشود. حقوق دختران بالاى يدر و مادر و جـكَونكى رعايت آن

ازدواج صورت مى گيرد و زاد و ولدى حاصل مىشود و در اين زاد و ولد دختران نيز هون مهمان بر سر سفره ى والدين جمع مى شوند، عدم يذيرش اين مهمان، بى اعتنايى به او حاكى از جهل و غفلت والدين است إز نظر

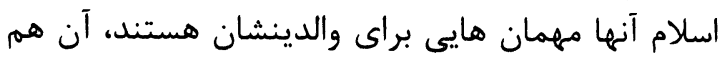
مهمانانى كه به پياى خود به اين سراى نيامده اند.

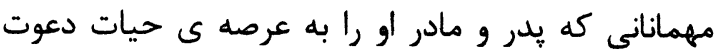
كرده اند و بايد قبول كرد كه اين دختران امانتهاى خدا

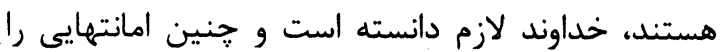
به آنان سيرده است. بنابر اين دختران را حقى بر والدين

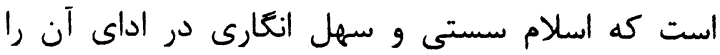
كُناهى نابخشودنى دانسته است. يس بر والدين است كه

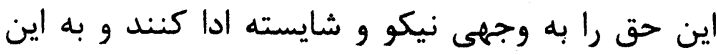
نكته توجه داشته باشند كه اداى حقوق آنها يك وظيفه ونه است نه يك احسان. اين خداوند است كه بار اداى اين

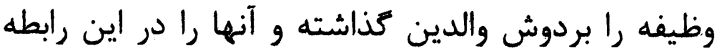

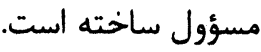
برخى از والدين دختران شان را اسير و برده ى خويش به حساب مىآورند و مانند يك برده با آنها برخورد مىنمايند و مراقبت لازم در دادن شخصيت و احترام به آنها مبذول نمى دارند. براى آنها ممكن است تلاش به آنه

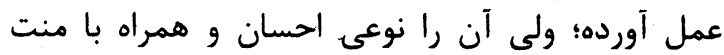
كذارى منظور مى كنند، در حالى كه رعايت اصول و ضوابط انسان نسبت به او حق اوست و والدين به اداى حق آنان مكلفند. 
و ما نمونه هاى بسيارى در اين مورد مىبينيه. حتى در

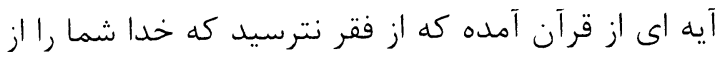
فضل خود بى نياز خواهد فرمود. يا در حديثى آمده است كه خوددارى از ازدواج به خاطر ترس از فقر نوعى عدم اعتماد(شركت) به خداست. F - انتخاب همسر: يكى از مسائل قابل توجهى كه در زمينه حقوق و آزاديهاى دختران مطرح است، موضوع انتخاب همسر و شريك زندگى است، گفته مىشود،

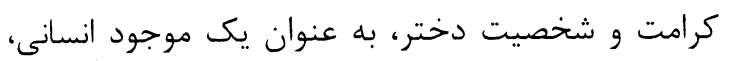
همانند يسر، اقتضا مى كند كه در حق انتخاب زوج و همسر، همانند يسر، آزادى كامل داشته باشد و در اين راه اراده ى ديخرى بر او تحميل نشود. يعنى ناخواسته زوجى را بر او تحميل ننمايند، و نه اراده ى ديخرى مانع تحقق انتخاب همسر براى او بشود. همان سان كه براى يسر، قانونا اين ترتيب وجود دارد. تبعيض و تفاوتى كه از اين حيث در جوامع مختلف بين دختر و يسر وجود داشت و هنوز هم وجود دارد و تحميلهايى كه در انتخاب همسر براي دختران و زنان اعمال مى

اكنون هم مى حيث در مورد آنها اجرا مىشد و حالا هم مىشود، مدافعين ارتقاء حقوق زن و طرفداران تساوى حقوق زن

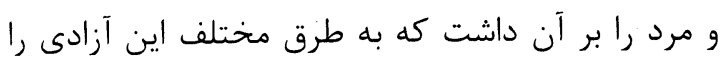

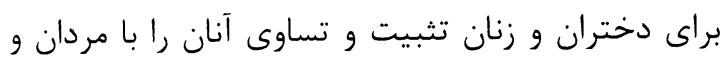
يسران در اين خصوص تأمين نمايند و در نتيجه اين حق، جزء قواعد مربوط به رعايت حقوق بشر براى زنان در اسناد مختلف بينالمللى حقوق بشر گنجانيده شد. از اين رو در ماده 1 أعلاميه جهانى حقوق بشر از تساوى حقوق زن و مرد براى انجام ازدواج و تحقق نكاح با رضايت كامل خود زوجين سخن رفته است. جنانجه فقرة r ماده مذكور مقرار مى دارد: ا|زدواج بايد با رضايت كامل و آزادانةٔ زن و مرد واقع شوده.
مىنمايند، از نظر اسلام، حرام و نارواست؛ زيرا خداوند متعال خود سهم شان را معين فرموده است. r- ازدواج: نظر به اهميت و نقشى كه ازدواج در حيات و سلامت جسمى و روانى افراد دارد، اين امر به عنوان حقى براى يسران و دختران ذكر شده است و كسى نمىتواند آنها را از اين حق محروم سازد. دررابطه به اين

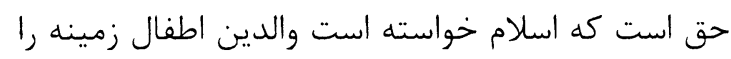
براى ازدواج او در سنين بلوغ فراهم آورند هم در رابطه با يسر و هم در رابطه با دختر. منع افراد از اين حق به حقيقت قبول زمينه بيمارى جسمى و روانى براى افراد و محروم داشتن او از لذات و مواهب زندگى، توليد و بقاى نسل و محروم داشتن از يك حيات شرافتمندانه است، امرى كه اسلام بدان رضايت نمىدهد. توصيههايى كه در اسلام راجع به ازدواج و تشكيل خانواده و يذيرش مسؤوليت است، بسيار است. رسول خدا در خطابى عام به جوانان فرمود: اى گروه جوانان بر شما باد ازدواج و تشكيل خانواده. در سخنى ديخر خطاب به مردى فرمود: ازدواج.كن و گرنه از زناهكارانى. همجنين سخنان ديگرى از رسول خدا(ص)در اين رابطه وجود دارد كه هركدام به نحوى مشوق افراد به ازدواج و تشكيل خانواده است. مثلا به اين جمله ها به عنوان نمونه توجه كنيد: - هركس سنت مرا دوست دارد تن به ازدواج دهد كه ازدواج سنت من است. - يك ركعت نماز فردى متاهل بهتر از • V ركت نماز فرد مجرد است. - آن كس كه ازدواج كند نيمى از دين خود را از خطر حفظ كرده است، بر اوست كه نيمى ديگر را دريابد. - ازدواج عامل عفت جشم و وسيلهاى براى حفظ ناموس و شرف است. 
بزركوار آمد و كفت: يدرش او را به ازدواج ناخواسته واداشته است، يِيغمبر دختر را مخير كذاشت. در اين كه پيدر اختياردار مطلق دختر خود در امر ازدواج

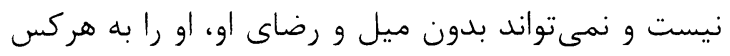
كه دلش مى خواهد شوهر بدهد، حرفى نيست. جنانجه

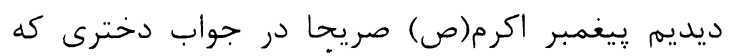

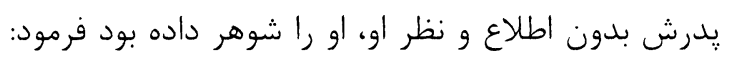

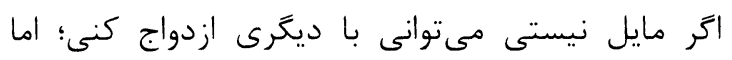

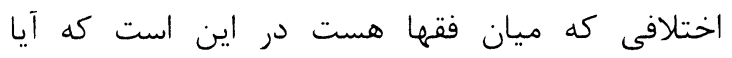

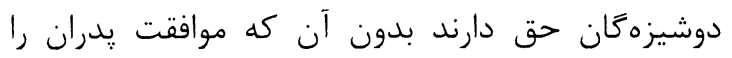

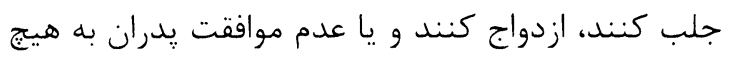

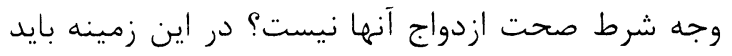

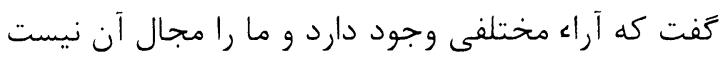

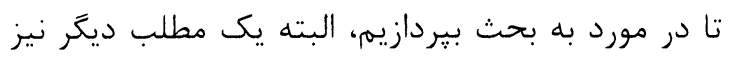

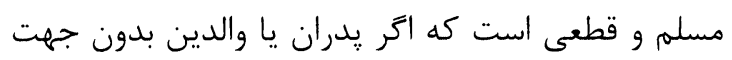
از موافقت با ازدواج دختران خود امتناع كنند، حق آنها آنها

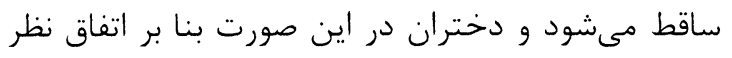

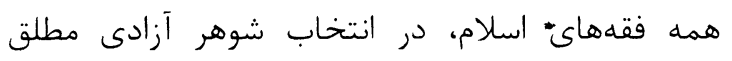

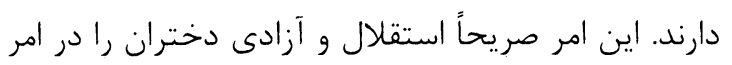
انتخاب هسمر و شريك زندگى و امر نكاح مىرساند.

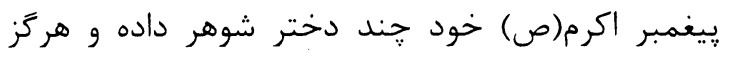

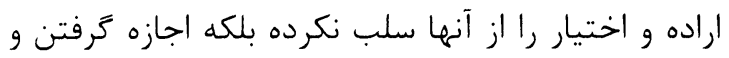

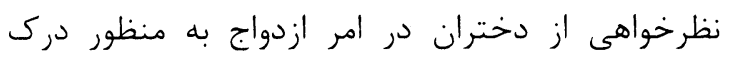

$$
\text { رضايت آنها سنت است. }
$$

ه- شوهر دادن قبل از تولد: در آخرين حجى كه

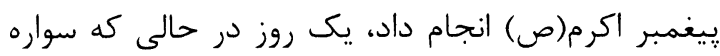

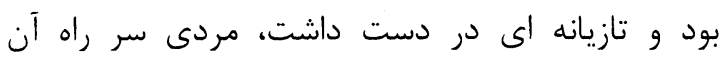

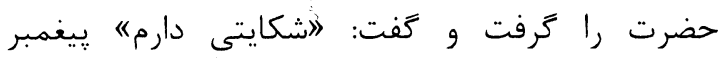

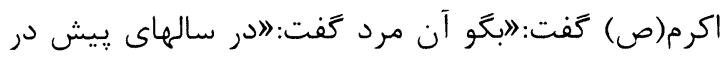
دوران جاهليت من و طابق بن مرقع در يكى از جنكَّها

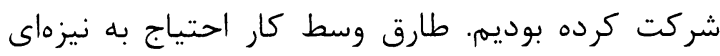
ييدا كرد. فرياد برآورد: اكيست كه نيزهاى به من برساند
از نقطه نظر اسلام دختر حق انتخاب در ازدواج را دارد و

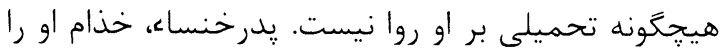

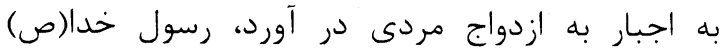

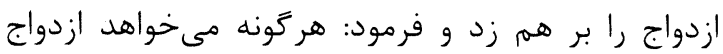

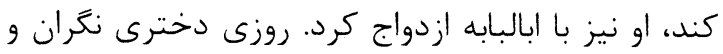

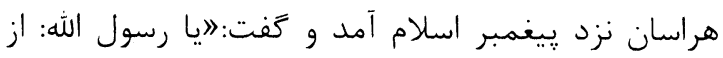

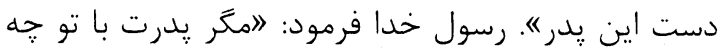

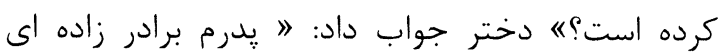

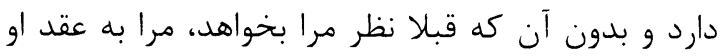

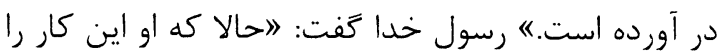

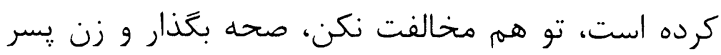

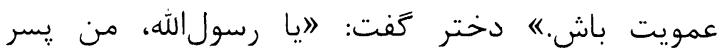

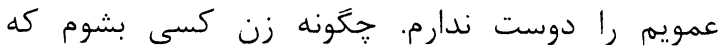

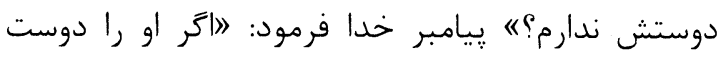

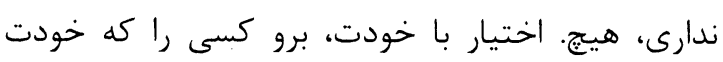
دوست دارى به شوهرى انتخاب كن. هن دختر دوباره

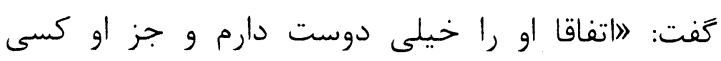
ديكرى را دوست ندارم و زنى كسى غير از او نخواهي دواهم شد؛ اما جون يدرم بدون آن كه نظر مرا بخواهد اين كار ندار

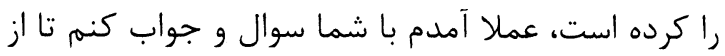

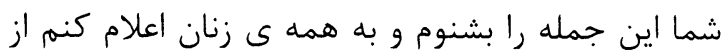
اين يس يدران حق ندارند سر خود هر تصميمى كه

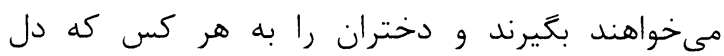
خودشان مى خواهد شوهر دهند."

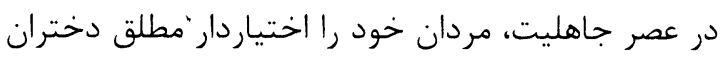

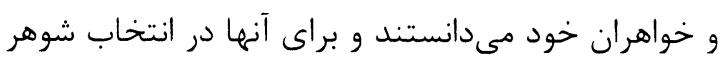
اراده و اختيارى قائل نبودند، تصميم ترفتن حق حق مطلق

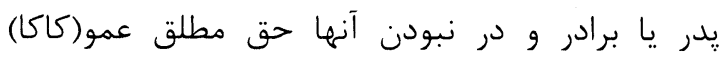

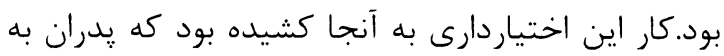

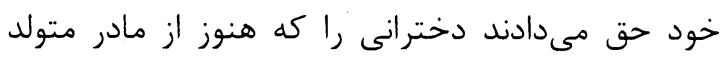

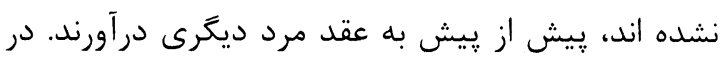

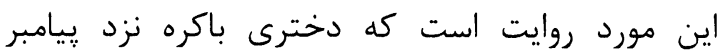


شان قرار دهند، روح لطيف و ظريف او كه متفاوت با يسران است را حس كنند، عامل جرأت و اطمينان او باشند. از احساس عميق او نسبت به زندگى سر در أورند

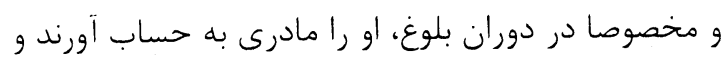
زمينه ى خير و فضيلت لازم را برايش فراهم آورند. r- موضع گيرى والدين نسبت به دختر: موضع يدر

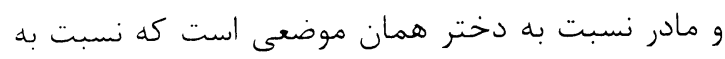
يسر يا ديخر فرزندان اتخاذ مى كنند: ولى با اين تفاوت كه دختر كمى حساس است و نازى تر. سعى بر اين است او را نرنجانند، هواى او و عواطف او را داشته باشند و او را آماده قبول وظيفه مادرى كنند. با اين كه بين يسر و دختر فرق نمى گذارند بهتر است به وى عنايت بيشترى نمايند. به همين خاطر اسلام دستور مى دهد كه اتر والدين هدية اى براى فرزندان تهيه كردند،

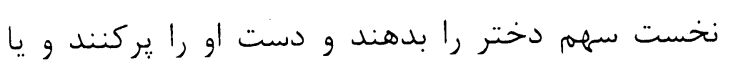

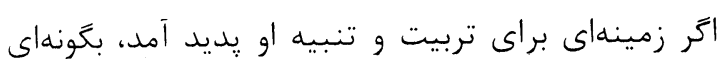
دختر را معاف دارند و تنمها به همان تذكر و اخطار قناعت نمايند.

والدين در مواردى با ذكر جملههايى بايد زمينه را براى

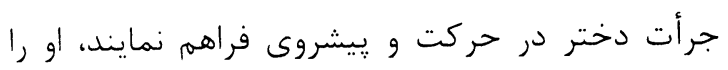
بايد به زندگى و انجام وظيفه تشويق نمايند. آنها با تمجيد از رفتار, دختر، ادب و اخلاق او مىتوانند

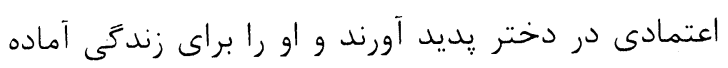

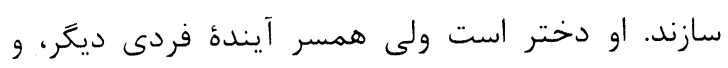

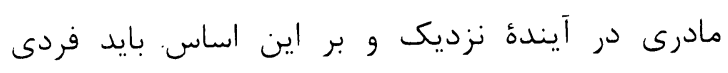
ارزشمند يرورده شود. همجنين بايد او را به طرف امور خانوادكى سوق دهند تا اعتماد به نفس ييدا كنيد. r- هدايت و تربيت: يكى از وظايف والدين در امر ارتباط با دختر هدايت و تربيت اوست؛ به به وجهى شايسته و به گونهاى كه او درخور وظيفه ى مادرى و لايق اداره و مديريت خانواده و يرورش فرزند گردد. آنها رالازم است آمادگى هايى به دختر بدهند و دختر بايد
زير شيوههاى رعايت حقوق دختران را به وسيله ى والدينشان به بررسى مى

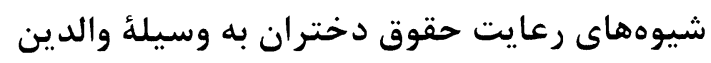
بينش اسلامى ما اين است كه فرزندان امانتهاى خداوندى در دست يدر و مادر و ديخرانند. همه در رابطه

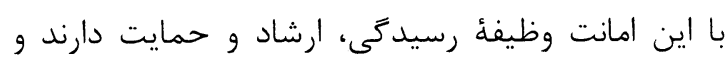
بايد بكوشند او را به ثمر رسانند و موجبات رشد ورئه

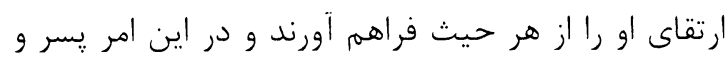
دختر مطرح نيست. طرز فكرى كه برخى از والدين درباره ى فرزندان يسر و يا دختر دارند و بدان خاطر درباره ى آنها تبعيض روا مى دارند، از اسلام نيست. يسر

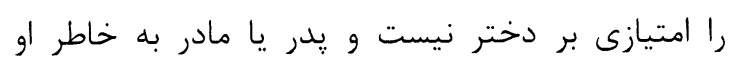

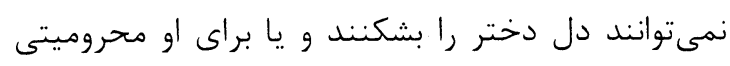

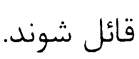

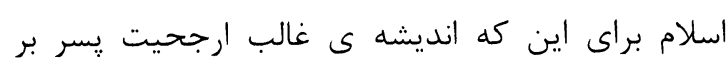

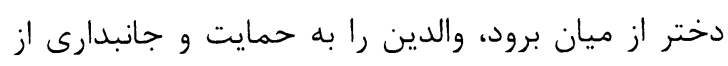
دختران سفارش كرده است. حال مىبينيم كه والدين

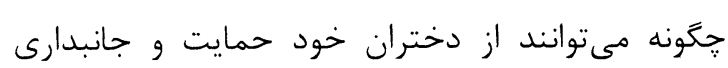
كنند و حقوقى را كه آنها دارند به وجه نيكو انهو اعاده نمايند. ا- نياز دختر به والدين: دختر هم به والدين نيازمند است؛ ولى والدينى مهربان كه رفتارشان لايق و درخور احترام باشد و او بتواند از آنها تقليد كند، او نياز به والدين قابل اعتماد دارد تا او را مورد توجه قرار دهند، از آنها الهام بخيرد، به آنها مهر و محبت بورزد و به وجود آنها افتخار كند. دختر نيازمند به والدينى است كه به بهر مجرى انضباط و عامل امنيت و اعتدال باشند، دشواريهاى زندگى را از ميان بردارند، توان حل و رفع

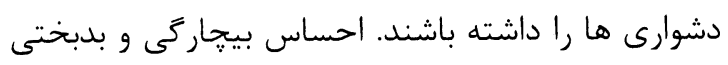
نكنند، اخر خطايى را مرتكب شد، به او زوشزد نمايند. او والدينى مىخواهد كه داراى روح مردانكى و عدالت باشند، از او رفع ظلم و تبعيض كنند، مورد توجه و علاقه 
بى رحمى ضمن اين كه به دختران صدمه وارد مى آورد، درس بدى براى زندگى آينده اوست. آنها همين درس را از كانون خانوادة زيدى به خانواده شوهر و از آنجا به اماكن ديكر و بالاخره به اجتماع مى كشانند. آن كس كه

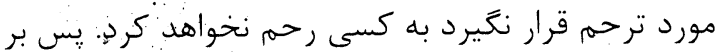
والدين است كه بايد با دخترانشان .با مهربانى رفتار نمايند.

از آنجايى كه نظر به آيات قرآنى و روايات، خداوند مدافع مظلوم است، از حقوق دختر كه قادر به دفاع از خود 1) نيست، دفاع خواهد كرد و روزگار ظالمان و ستمكاران تباه خواهد ساخت. خود و دختر خود را در محضر خدا ببين و با او برخورد كن و از ظلهم هركسى كه جز خدا يناهى ندارد، بيرهيزد، كه آه مظلومان سخت سوزاننده

در مواردى بسيار لازم است والدين گستاخى دختر رابر او ببخشند، خطاى او را ناديده زيرند، بر او مهر و عاطفه روا دارند و حتى نحذارند اشك او جارى گردد. جه. بسيارند رواياتى كه به ما هشدار مى دهند كه دختر راز كتك زدن معاف داريم.

ه- عدم برخورد تبعيض آميز: دختران نمىتوانند بيذيرند كه والدينشان آنها را به خاطر جنساش مورد طرد و تبعيض قرار دهند و با بى اعتنايى به شخصيت و تحقير او مورد بى مهرى اش قرار مىدهند. جنين امرى عواقب وخيم براى دختر دارد و عملا از والدين درس بدى مى ₹يرد، ضمن اين كه والدين نيز مورد تنفر قرار مى گيرند. دخترى كه مورد تبعيض قرار مى گيرد، ممكن است از زندگى بترسد و در كسب احترام و امنيت خاطر با دشواريهايى مواجه شود و اگر اين تبعيض به خاطر جنس باشد او در ايفاى نقش آيندة زنانه خود دجار دشواريهاى بسيار مى گردد.
آكاهى هايى حاصل كند كه براى فرداى او مورد نياز والدين بايد براى دختر راهنماى فكرى خوبى باشند، افكار و عقايد او را بسازند و كمبودهاى او را جبران نمايند، به هدايت انديشههاى دختر خود بيردازند. استعدادهاى خاص او را جهت دهند. زمينه رشد و يرورش و مسؤوليت يذيرى را در آن فراهم آورند. همجنين دختر در امر تمرين كار و شغل در خانه، رسيدگى به امر زندگى و سروسامان دادن كارهاى منزل و حتى نكمهدارى فرزندان آنها را وا مى دارد كه در مسير زندگى قرار گيرند. اين در خواست بايد در بهلوى ديخر مراقبتهايى باشد كه والدين در امر تحصيل و فراخيرى أَاهى هاى لازم از فرزندان دختر خود به عمل مى آورند و در آن زمينه هم او را رشد مى لمهند. F F- در برخوردها: در مواردى ممكن است دختر هم مانند يسر دجار لغزش و خطا شود. شك نيست كه خطاها بايد از زندگى رفع زردد و او راه صلاح و سازگارى در يِيش گرفته شود؛. اما نحوه ى برخورد والدين با او متفاوت با شيوه اي است كه در رابطه با يسر اتخاذ مى كنند. خشونت والدين در تربيت كارساز نيست اگرجه ممكن است از وقوع امرى جلوگيرى نمايد و مشكلى را به صورت موقت از ميان بردارد؛ اما اعمال خشونت كارى ناروا و رفتارى نايسند و براى دختر نايسند تر است. عاطفه دخترى و ظرفيت روانى او جنان نيست كه او بتواند خشونت والدين را تحمل كند و جه زشت است رفتار آن والدينى كه دخترش را سيلى زنند و يا مشت و لعد نثارش كنند. اين امر براى روحئ ظريف او بسيار نا مناسب و براى آينده او بسيار نا يسند است. زور كَفتن به دختران كارى دشوار نيست و خشم كَرفتن بر آنها زحمت بسيار نمى خواهد؛ ولى فراموش نكنيم كه اين كليد هر بدى و رسوايى است. خشونت و 
با دختر برخورد كننب كه او از محبت يدرانه و مادرانه اشباع گردد و نيازى به محبت غير نباشد. 9- يذيرش: اين خطاى بزرگى است كه برخى از والدين دختران خود را آنجنان كه شايسته است، نمى يذيرند و مورد محبت قرار نمىدهند. دختر إز اين امر شديدا ناراحت مىشود؛ مخصوصا از آن بابت كه در جنسيت خود صاحب راى و نظر نبوده است. اين عدم يذيرش ممكن است به خاطر زشتى و زاهى هم به سبب نارسايى در بدن و يا اخلاق و ادب باشند. از نظر اسلام، دختر در خانهاى كه به دنيا مى آيد، بايد يذيرفته شود، جهه زشت و جهه زيبا، سالم يا ناقض. ممكن است براى برخى از والدين دختر نا خواسته باشد و يا والدين خلاف او را در ولادت انتظار داشته اند و يا تعداد فرزندان را كافى مى دانسته و وجود او را نمى يذيرفته اند. اين مسأله هم فعلا بايد حل شود و اينك كه او به دنيا آمده، بايد مورد قبول قرار گيرد. اساس فكر در اين يذيرش آنست كه او امانتى از خداست در دست والدين و آنها وظيفه دارند او را به عنوان موجودى گرانقدر يذيرا گردند و به حفظ و حراست او و هم به تكميل و يرورش ابعاد وجودى او بيردازند. •l- احترام: دختر آفريدة خدا و امانتى در دست يدر و و مادر است، قرآن او را (بنى آدم را) از جانب خدا(ج) موجودى گرامى و مورد احترام معرفى مىكند. براين اساس آن كس كه مورد تكريمم و عنايت خداوند است، نبايد مورد بى مهرى و بى اعتنايى ديگران باشد و حتى يدر و مادر حق ندارند او را مورد اهانت قرار دهند. والدين نه تنها بايد او را مورد احترام قرار دهند بلكه بايد زمينه را براى گسترش احترام و علاقهاى متقابل يديد آورند. بينش اسلامى مى گويد اين احترام حق طفل است نه عنايت والدين. |l- اعلام سرور و سرفرازى: والدين بايد از تولد دختر احساس غرور و سر افرازى كنند و هرگز آرزوى مرى او
צ- توجه: توجه والدين به دختر بايد بيشتر از يِنر باشد، در دادن هذيه و در مهرورزى نسبت به او دقايق بيشترى را بايد مورد نظر داشته باشند؛ زيرا كه او در آينده اى نه جندان دور مادر خواهد شد و عاطفه لى مادرى او نبايد صدمه ديده و ضربه خورده باشد. V- عدالت و مساوات: رعايت مساوات ميان فرزندان از نظر اكثريت قاطع علما مستحب و مطلوب است. زيرا عدم رعايت عدالت و مساوات ميان فرزندان زمينه ران براى منازعه و دشمنى و كينه ميان آنها فراهم مى ركى نمايد. بنابر همين علت است كه از نظر اسلام رعايت اصل 》عدالته در همه زمينه ها واجب رينداشته شده است. در اين رابطه اضافه بر قرآن روايات زيادى آمده از نعمانى بن بشير روايت شده كه رسول خدا فرموده اند: "در ميان فرزندان خود به عدالت رفتار كنيد". 1- ابراز محبت: محبت عامل زيوند و ايجاد همبستگى مئى بين افراد است و اتر نبود، انسى در بين انسانها به وجود

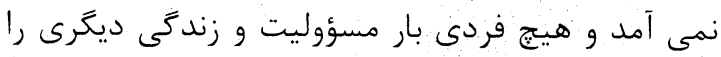
بر دوش نمى تعادل و ايثارى گيديد نمى آمد. دخترى كه احساس كند مورد محبت و عنايت نيست، به جستجوى محبت مى رود و در اين جستجوست كه ممكن است دجار لغزش و انحراف شود. يس بر والدين است كه به دختر محبت ورزند، او را دوست بدارند و دوستى خود را به او نشان دهند. در سنين خوردسالى او را دركنار خود گيرند. دست نوازش بر سر او بكشند. او را ببوسند و در صورت ناله و زريه از او دلجويى نمايند. اين اعمال محبت ها در رشد عاطفى طفل و سازندگى او بسيار موثر است و او را فرد شايسته و مادرى مهربان بار خواهد آورد. در سنين نوجوانى و بلوغ با همه مهر و محبتى كه دربارة او اعمال مىشود، بايد مراقبتها هم در اين زمينه اعمال گردد. همجنين ضرورى است كه در خانواده والدين به گونهاى

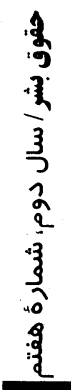

rA 
مادر مى آموزبد جكَونه زنى باشد؛ ولى او از يدن ميى آموزد

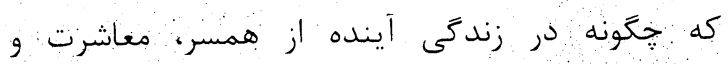
مشاركت بحواهد.

يدر بايد به دختر احترام بخذارد و فرديتش را مورد توجه

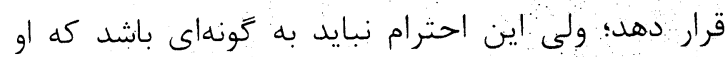

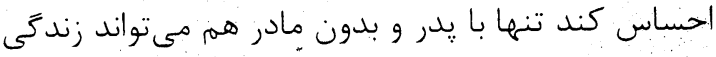
كند. محبت بيش از حد يدر به دختر سبب مىشود كه

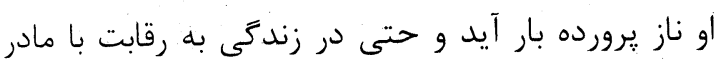

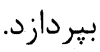

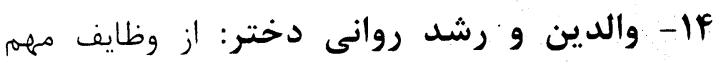

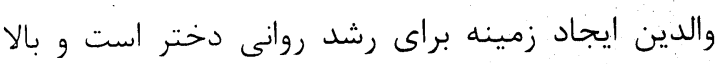

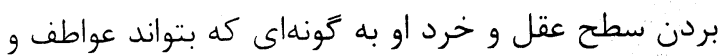
احساسات خود را تعديل نمايد و والدين در اين زمينه مىتوانند نقشى فوقالعاده داشته باشند. در ايجاد اين رشد روانى، نخست لازم است والدين ملاحظاتى دوستانه و صميمانه بين خود و دخترشان را يديد آورند.

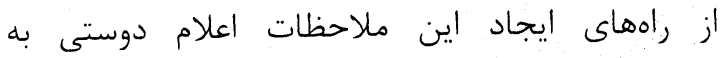

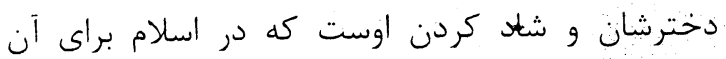

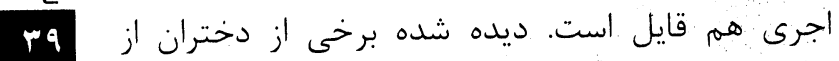
خانواده بريدند تنها بدان خاطر كه نقطه اتكاى در خانه

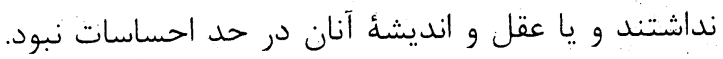
رفتار زنندهاى داشتند بدان خاطر كه ملاحظاتى فيمابين

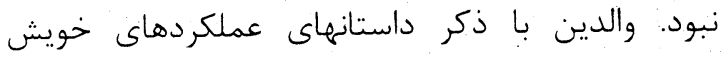

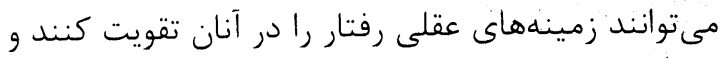

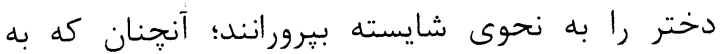

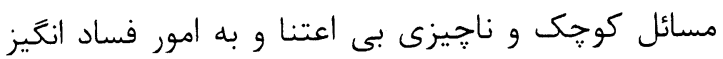
بى توجه و از آن روى گردان باشد.

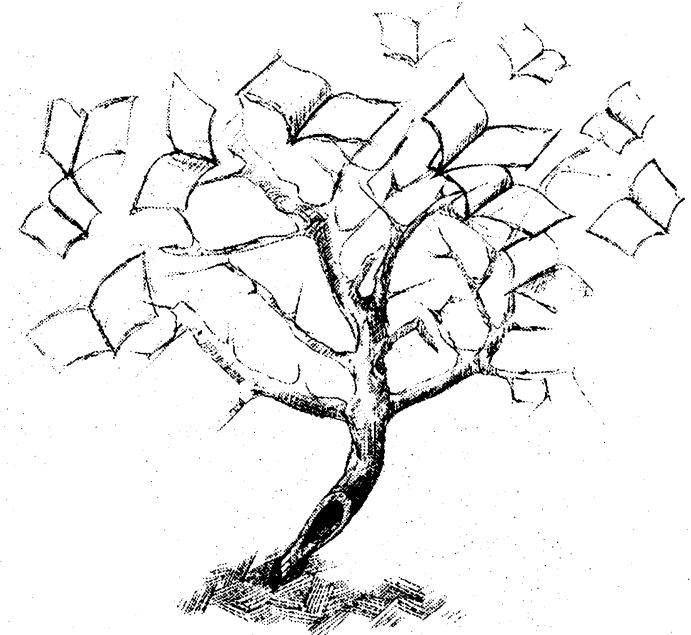

را نكنند؛ زيرا خداوند آن را تحريم كرده است؛ جنانجه

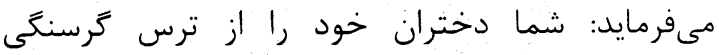
نكشيد. و يا حضرت محمد(ص) مىفرمايد: بهترين المرانين فرزندان شما دختران شمانست. r إ- منع ها: جه بسيارند مسائل و امورى كه يدران

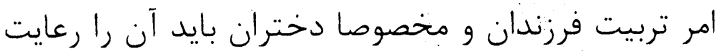

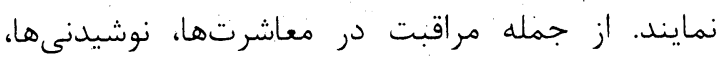

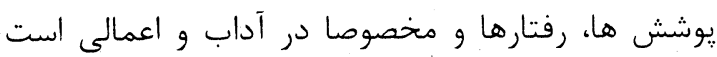

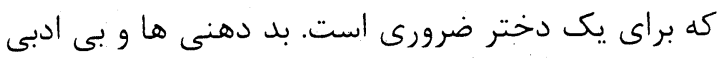

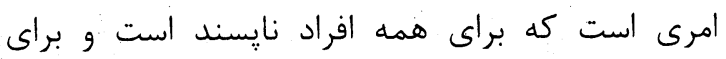
دختران نايسندتر. دختران را وقارى بيشتر لازم است و بايد بيش از يسران مر اقب سخنان خود باشند.

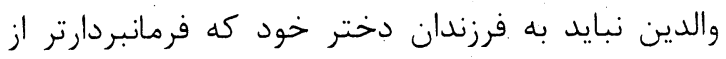
پِران هستند زور بكويند و از او وظيفه اى را را بخواهند

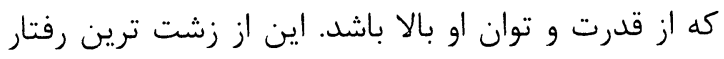
هاست كه يدرى يا مادرى از مظلوميت و حياى دختر استفاده كند و تكليف سخت به او واكذار نمايد.

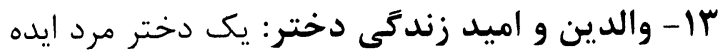
آلش را در زندكى از طريق بدر شناسايى مى كند و بيش

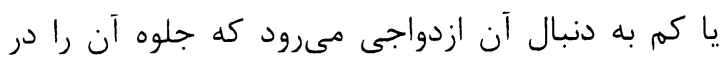

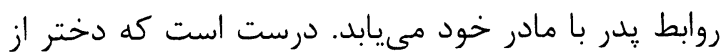


جـي د حُانحسـانيو، تويسك مـاريو او نسورو سـتونزو او كر اوونو خخه د خلاصون لاره كومه يوه ده؟

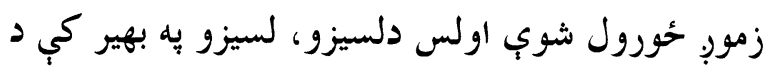
خود كامه او خبل سرو نظسامونو د زور زيساتى او نساروا لاندي د زوند ذُبري ترخي شبي او ورخي تيسرى كـري،

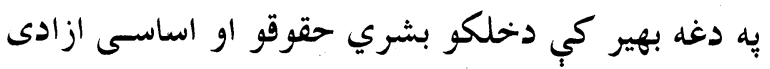
تر هبنو لاندب شول، مرينه، زوبله، ويجارتيا، غربست او

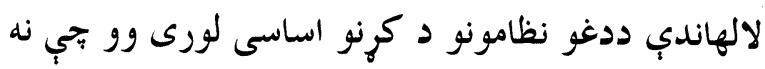
يو احٔي دهيواد مادى او معنوى شتمنب تسالان او زيسانمنب كري بلكى سترى، سترى بشري غميزى يب اولس ته به

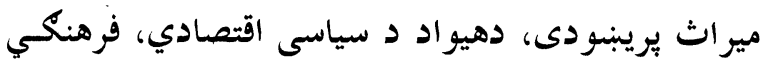

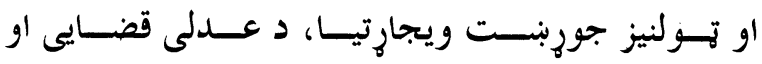

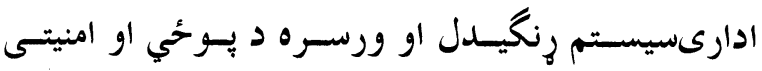
ثانكو له منحُه تلل د دغو لسيرنو د ناخو الو او سستونزو يوه غتبه بيلكُه بلل كيداب شي.

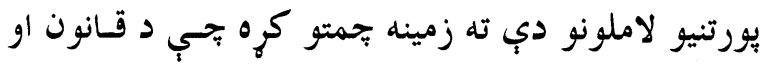

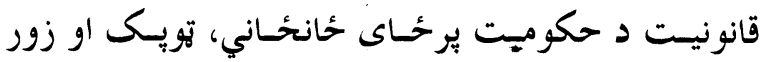
زياتى د خلكو بر برخليك حساكم او د زورد خاونسدانو

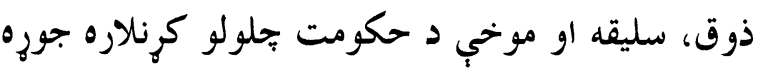

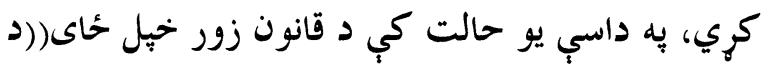

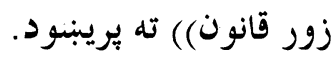

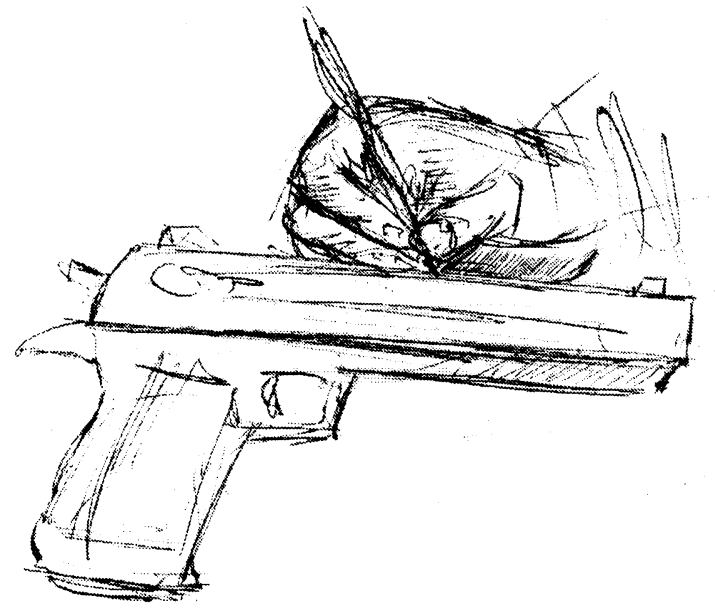

\section{ن-خر گند}

دهيو اد به معاصر تساريخ كب افغسان اولس د سـولى، د موكراسي او مدني تولني د جوريسدو لِيساره يسو تساريخي

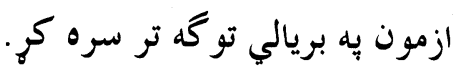

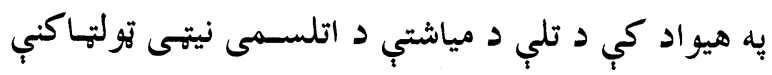

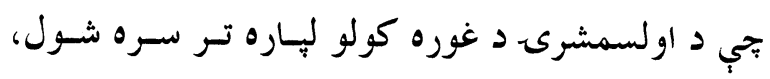
يخخيل ذات كي د دمو كراسى او دخبلي رايسي د ازاد نسه كاروني به اره لومينى كام شميرل كيداب شي.

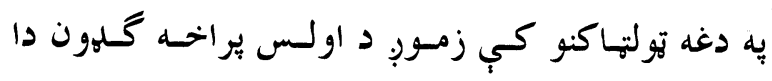
حقيقت يو حُل بيا جوت كر تجي زموب. اولس نور دخيسل

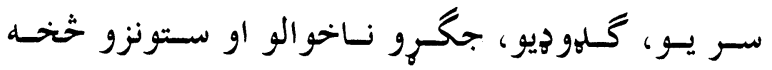
ستومانه او كر كجن شوي او يسه خيلس رايسى سـره يسي

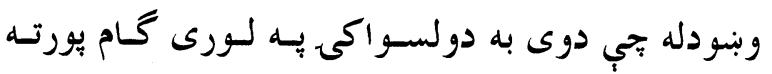

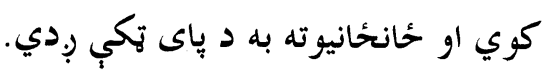

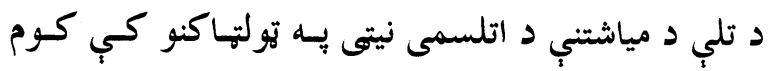

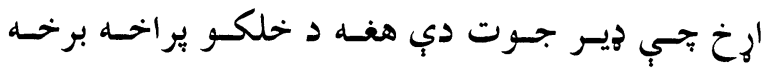

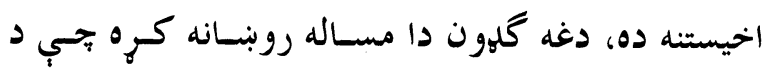

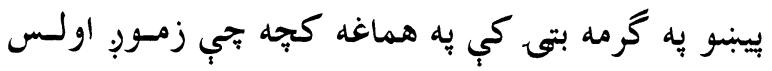

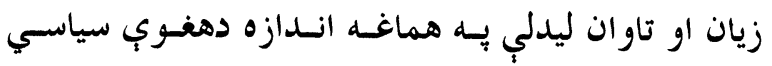

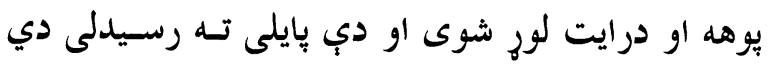


حوادثو او بيبنو به گُمه بتق كي زموجٍ د خحلكو سياسى

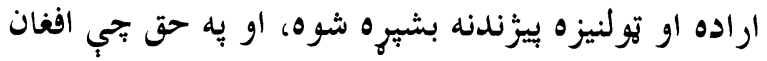
اولس دغى بيززندنى او د سياسى ارادى د بخــوالي لبـاره

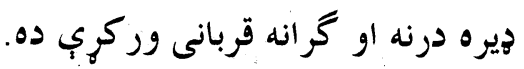
له نيكه مرغه زموجٍ. اولس د قرباني بـهـ بايلسه كي لاستسته

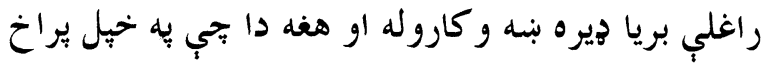
كلهون سره يب د دمو كزاسى، مدني.تولني، ازادى ارادى او د بيان او رايى د ازادى لِاره خيله خوبنه و كاروله.

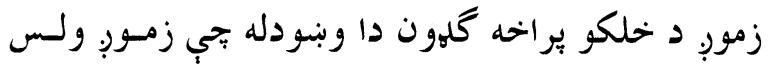
خبل برخليك بخيله تاكلى شي خوله بده مرغه له هغوي نه داحق اخيستل شوى وو.

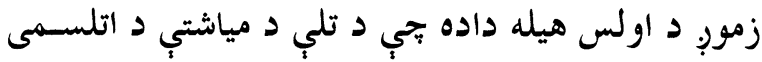
نيتى تولتباكني هغه فضا او شرايط تجي د (زور دقانون) له

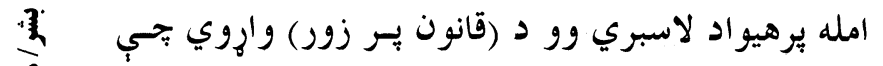
به بِيله كي ديوه عادلانه بياوري او باثباته سياسسى نظـام

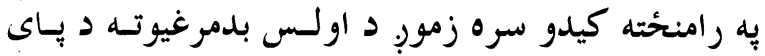
تكبي كيبنودل شي.او د انساني حقوقو او اساسي آزاديو

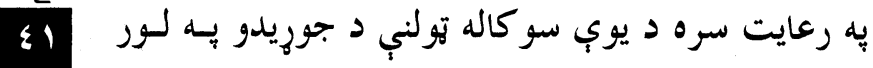
اساسى كامونه واخيستل شي.
د تلي د مياشتني د اتلسمى نيتهى يـه تزولتهاكنو كي كوم ارخ جي دير جوت دي هغه د خلكو يراخه برخه اخيستنه ده، دغه گلهون دا مسـاله

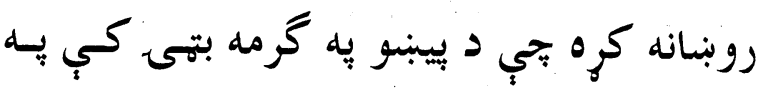
هماغه كجه بجي زمسوبِ اولـس زيـان او تـاوان ليدلي به هماغه اندازه دهغوب سياسي بوهه او درايت لوز شوى او دي يايلى ته رسـيدلى دي جي د حخانحأيو، توبك ماريو او نورو سـتونزو او كراوونو خخه د خحلاصون لاره كومسه يسوه

so

د ((زور د قــانون)) بــه رنــا كـي، زور واكسو، تــولنيزه

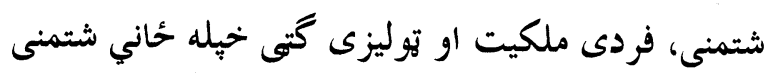
و بلله او زموبٍ د خحلكو بِه يرغمل نيولو سره يبي دخبلسو

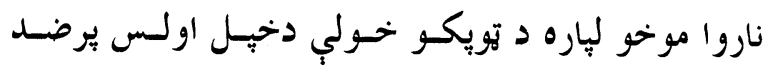

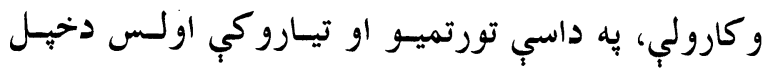

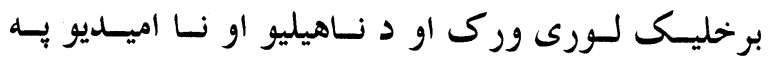
سباوون يب سترگى ونبنلولي.

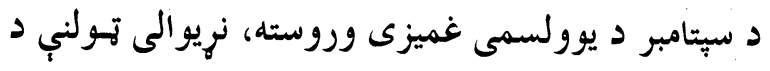

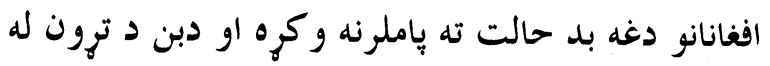
مخي ديوي منحُ مهالى او لنه مهالى ادارى لِيساره زمينسه

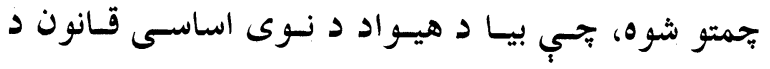

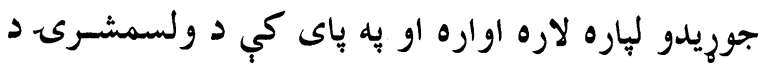
تاكنو لِاره شرايط رامنحته شول.

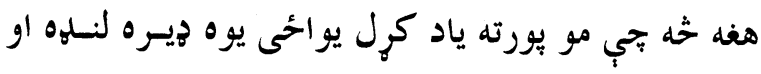

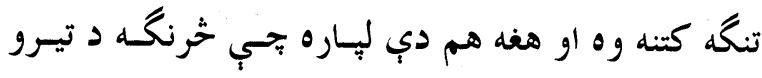


تبادله و خريد و فروش آن اقدام و از تمام حقوق انسانى محرومش ساخته بودند و حتى او را از شرم
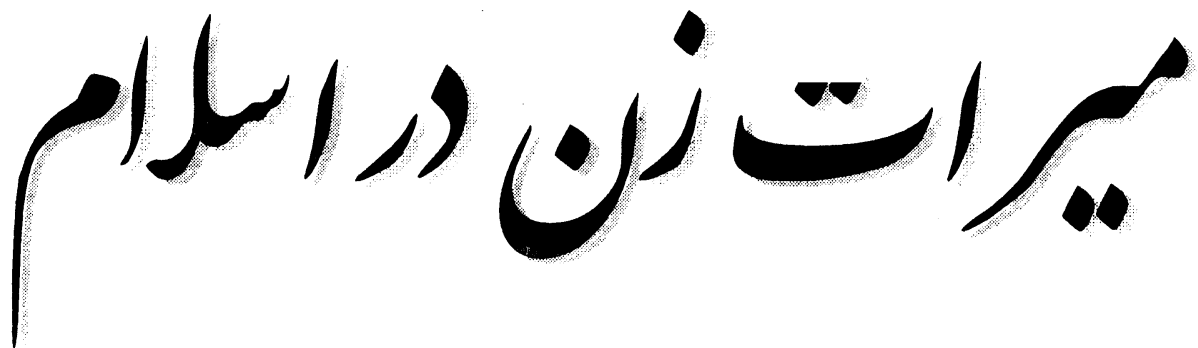

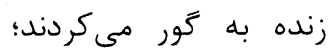
اسلام از همان بدو انتشار

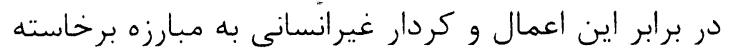

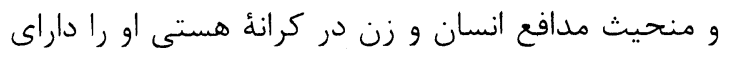
نورجهان يوسفزى حقوق معينى ينداشت. زن و مردى كه از يك نفس واحد خلق شده اند. از لحاظ ماظ خلقت و انسان بودن هيج گونه مزيتى نسبت به يكديكر

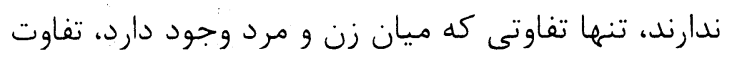
طبيعى خلقت آنهاست به عبارة ديخر زن و مرد نظر به مقتضاى طبيعت از همديكر متفاوت اند كه اين تفاوت نظر به درجة عواطف احساسات آنها مىباشد. خداوند متعال در قرآن مجيد زن و مرد را يكجا مورد خطاب عام قرار داده هردو را داراى حقوق معين ينداشته و به همان مناسبت مكلفيتهايى برايشان ذكر و جهت رعايت حقوق و تكاليف مأمورششان تردانيده است. همه را يكسان در صورت ارتكابِ اوامر الهیى .و اجتناب از نواهى اش متحقق اجر و پاذاشاش جنت و در صورت نافرمانى وعده عذاب و دوزخ داده است و در اين رابطه هيج نوع تفاوتى ميان زن و مرد وجود ندارد. خداوند متعال در آيهٔ ذيل زن و مرد را در كنار هم قرار داده مىفرمايد: واقعا مردان و زنان مسلمان و مردان و و زنان با ايمان و مردان و زنان اهل طاعت و عبادت، مردان و زنان راستخوى، مردان و زنان برده بار، مردان و زنان خدا ترس، مردان و زنان خيرخواه مسكين نواز، مردان و زنان روح دار و مردان و زنانى كه عفت خويش را نغه مى دارند. و مردان و زنانى كه ياد خدا را بسيار مى كنند، براى همهٔ آنها خداوند مغفرت و ياداش بزرى مهيا ساخته است، هيج مرد و زن مومنى را در كارى كه

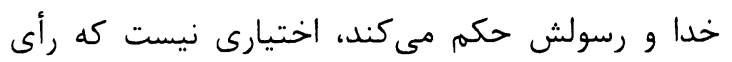
تاريخ بشريت شاهد صدها رأى متفاوت و متناقض در باب شخصيت انسانى زن، جايگاه اجتماعى و حقوق وى لـ

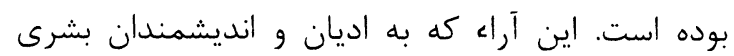

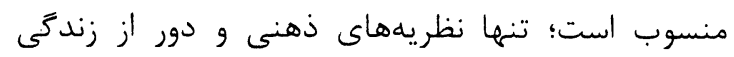
نبوده؛ بلكه يايه و مبناى رفتار مردان نسبت به زنان يا

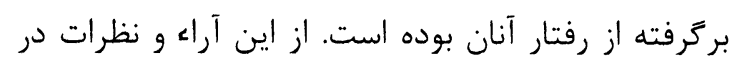

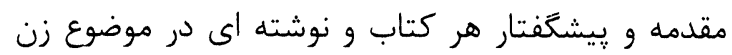
يا به تحقيق يا به تقليد، فراوان به جشم ميى خورد. تفاوت هاى زن و مرد، از اين گَفته معلوم مىشود كه هنوز هم با اين كه در قرن بيست و يكم هستيم، در گوشه و كار افرادى پييدا مىشوند كه طرز تفكر قرون وسطايى دارند و فكر كهنه و يوسيده ى تفاوت زن و مرد را دنبال مى كنند و خيال مىكنند زن و مرد با يكديخر تفات دارند، ولابد مىخواهند مانند مردم قرون وسطى نتيجه بخيرند كه زن جنسى يست تر است، زن انسان كامل نيست، زن برزخ ميان حيوان و انسان است، زن لن لياقت و شايستخى اين كه در زندگى، مستقل و آزاد باشد را ندارد و بايد تحت قيموميت و سريرستى مرد زندگى كند. اسلام يعانه دينى است كه ارزش واقعى زن را مانند يك انسان به رسميت شناخته و بانظرداشت اين مطلب كه زن و مرد از يك سرشت آفريده شده اند و داراى طبيعت بست مشابه و جفت هم اند، هردو را داراى حقوق انسانى مساوى مى داند. جوامع وحشى كه اصلا ارزش انسانى زن را منكر بوده و او را مانند ابزار و وسيله دانسته به 


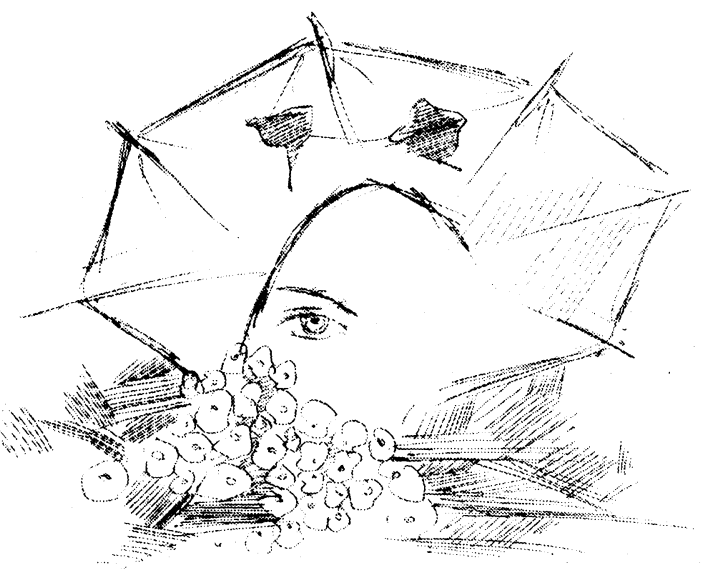

قانون خلقت براى اين كه زن و مرد را بهتر و بيشتر به

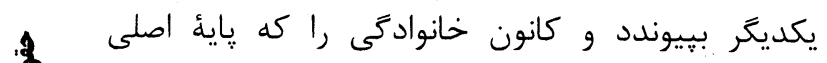
سعادت بشر است. استوارتر سازد، زن و مرد را نيازمند به

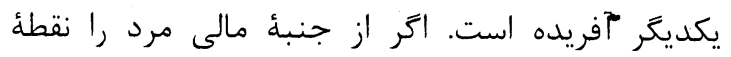

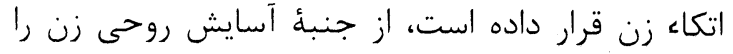

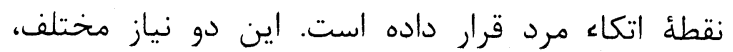
بيشتر آنها را به يكديكر نزديك ساخته و متحد مى كند. مسأله ارث

دنياى قديم يا به زن اصـلاًا ارث نمسى داد و يـا ارث مسى

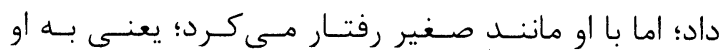
استقلال و شخصيت حقوقى نمى داد. احيانا در بعضى از قوانين قديم جهان اگر به دختر ارث مىدادند به فرزندان

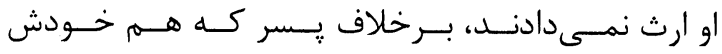
مىتوانست ارث ببرد و هم فرزندان او مىتوانستسند وارث مال يدركلان شوند و در بعضى از قوانين ديگر جهان كه به زن مانند مرد ارث ميى دادنـد، نـه بـه صـورت سهميه قطعى و به تعبير قرآن "انصيبا مفروضاه بود؛ بلكه به اين صورت بود كه به مورت حق مى دادند كه دربـاره دختـر خود نيز اتر بخواهد وصيت كند.
خلافى اظهار نمايد و هركس نافرمانى خدا و رسول او را كند، دانسته خود را به كمراهى آشكار انداخته اند. طورى كه ملاحظه مىشود در تمام موارد فوق كه برشمرده شده اشت، زن و مرد داراى يك حق و امتياز

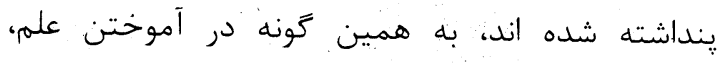
تحصيل، معرفت، داشتن ملكيت تصرف در اموال، اجراى معامله، اجراى كار و غيره فرق ميان زن و مرد وجود

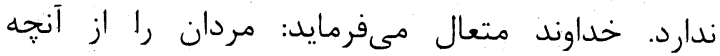

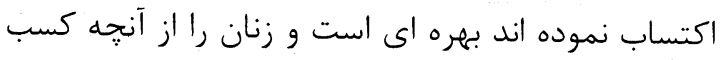

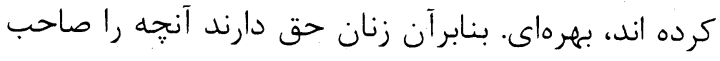

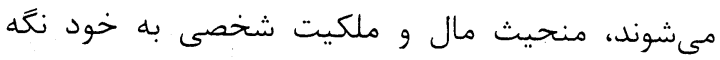
دارند، مالك دسترنج خويش باشند، فعاليت آزادانئ اقتصادى را انجام دهند. هيج كس ديكر به شمول شوهر حق مداخله در اموال آنان را بدون اجازه شان ندارد. تفاوتى را كه اسلام در مورد قبول نموده عام است و آن هم تقوى، نيكى و خوبى است كه تنها منحصر به مرد نبوده؛ بلكه زنان نيز در اين قسمت سهيهم دانسته شده اند. جنانجه قرآن مىفرمايد كه: لامردان و زنان مسلمان دوست و حامى يكديگراند، به معروف امر مى كنند و از

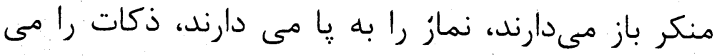
يردازند، خدا و رسولش را فرمان مي برند، آنان كسنانى دانى هستند كه خداوند به ايشان رحم خواهد كرد. به درسى ترى

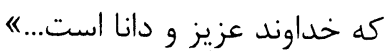
اما يك انسان واقع بين كه تحت تاثير هو و جنجال نباشد و تمام جوانب را ببيند، مى داند كه نه قانون خلقت، مرد را يكى از وسائل معاش زن قرار داده و نه اعلاميئ حقوق بشر "بيوهزى" را به عنوان از دست دادن ان

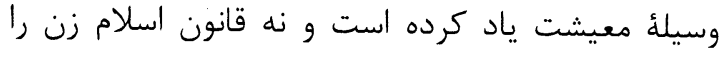
واجبالمنفعه مرد شمرده است، هيج كدام به زن توهين نكرده اند، جون اين يك جانب قضيه است كه زن نيازمند به مرد آفريده شده است و مرد نقطه ى، اتكاء

$$
\text { زن شمرده مىشود. }
$$


محروميت زن از ارث عللى ديخر نيز داشته اسـت؛ از آن

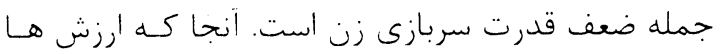

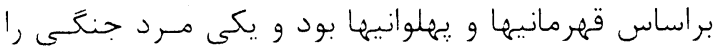

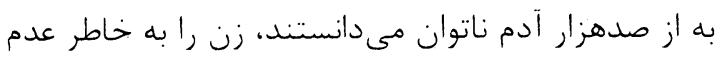
توانايى در انجام عمليات دفاعى و سربازى از ارث محروم مى كردند. عرب جاهليت از همين نظر مخالف ارث بردن زن بود و تا ياى مردى ولو در طبقتات بعـدى، در ميـان

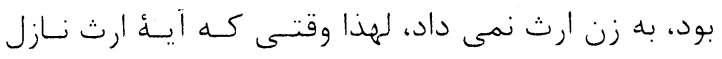
شد، باعث تعجب اعراب شد، اتفاقـا در آن اوقـات بـر ادر

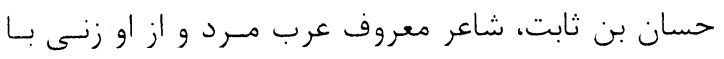
جند دختر باقى ماند، يسر كاكاهاى وى همسه داراى وى

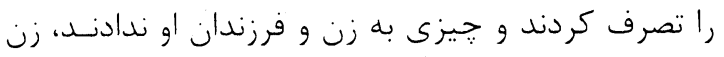

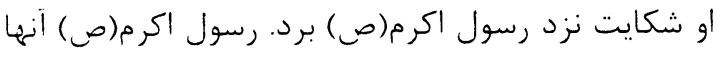

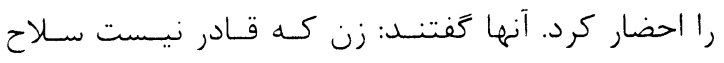
بيوشد و در مقابل دشمن بايستد، اين ما هستيم كه بايد شمشير دست بخيريم و از خودمان و از ايسن زنهـا دفـاع كنيم، يس ثروت هم متعلق به مردان بايد باشد. ولى رسول اكرم(ص) حكم خداوند را برايشان ابلاغ كرد. ارث بسر خوانده

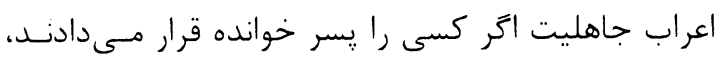

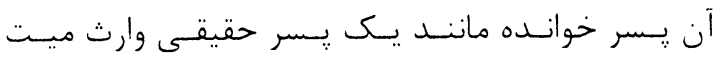

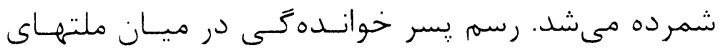

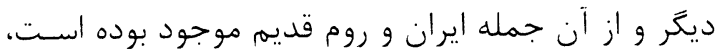

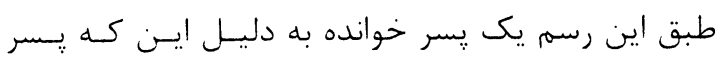

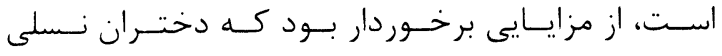

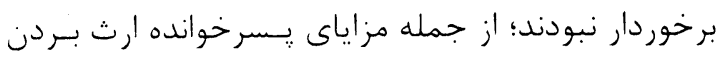

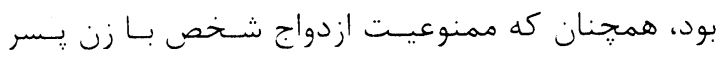

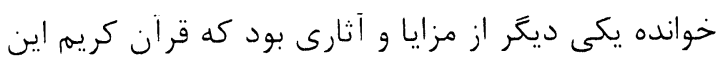
رسم را نيز منسوخ كرد. ارث هم ييمان اعراب رسم ديخــرى نيـز در ارث داشـتـند كـهـ آن را نيـز

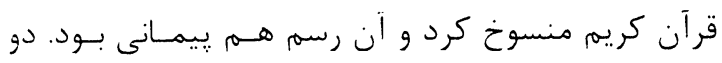

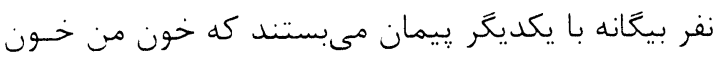

تاريخجه ارث زن طولانى است، محققين بحثنهاى فراوانى

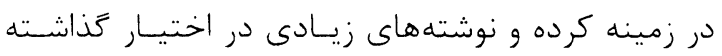

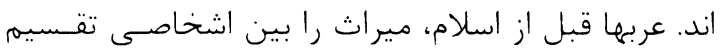

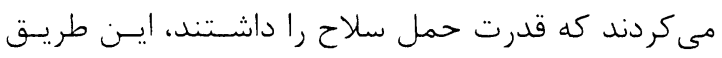
مدت زيادى اساس توزيع ميراث بينــشان بـود. اطفـال و زنان را مستحق ميـراث نمسى دانسستند و زنسان نـه تنهـا مستحق اخذ ميراث شناخته نمى شيدند؛ بلكه مثـل سـاير اموال متوفى به ميراث برده مىشدند و به كمال حقارت،

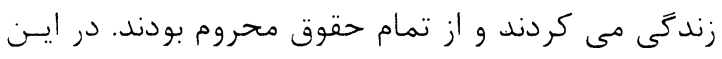
وقت ظلم و فساد تمام اطراف و اكناف جزيره عربى را فرا

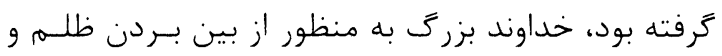

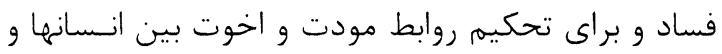

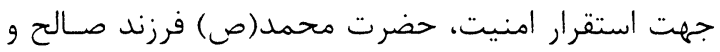
با شهامت عالم بسشريت را بـراى خيـر و صـلاح بسشريت

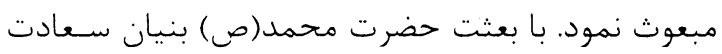
و فلاح عالم بشرى گذاشته شده و تحول بزرگى در نظام

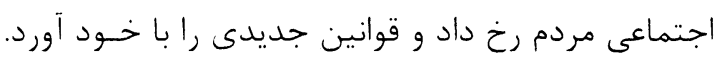
اما براى اينكه تحمل قوانين جديد بـالاى مـردم مـشكل

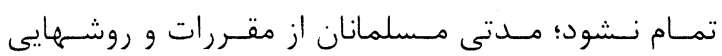
ييروى مى كرند كه قبل از اسلام بين شان رايج بود. علل محروميت زن از ارث علت اصلى محروميت زنسان از ارث، جلـو زيرى از انتقـال

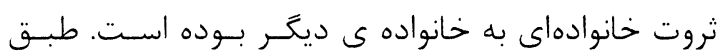
عقايد قديمى نقش مادر در توليد فرزنـد ضـيف اسـت،

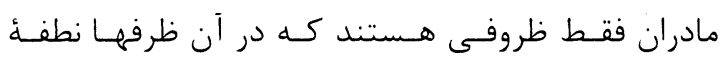
مردان يرورش مى يابد و فرزند به وجود مى آيـد، از ايسن

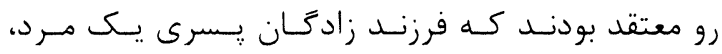

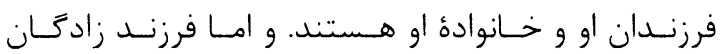
دخترى او، فرزندان او وجزء خانواده او نيستند، بلكه جزء خانواده يدر دختر محسوب مى شىـوند. روى ايسن حسـاب

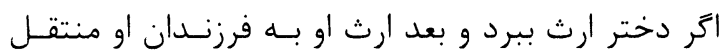

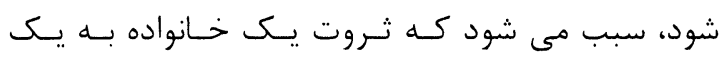
خانواده ى بيعانه منتقل زردد. 
ايمان براى سعادت خود اقدام نمايند. بدبينى و حد را از بين خود دور سازند، حقوق يكديگر را محترم دانسته، از ظلم و تجاوز دست كشند و زير بناى يكى زنسدگى آرام و مسعود را كه كرامت انسانى مقنضى آن است، بخذارنسد و براى تامين اين مأمول و به منظور استحكام رشتهٔ اخوت و مودت و محبت بين مسسلمانان جهـت تقويـه اتحساد و اتفاق بين شان بـراى تسشكيل يـك ملـت قـوى يكسى از اسباب ميراث در صدر اسلام حينى كه مسلمانان در مكه بك بـ مكرمه در ضعف و قلت بودند، هجرت از مكه مكرمسه بــه مدينه به منظور استقرار برادرى بـين مهـاجرين و إنسار

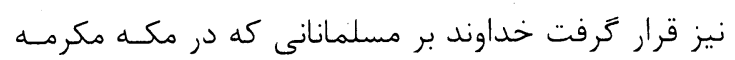
زندگى مى كردنـد. هجــرت بـه مدينـه را واجسب و لازم ساخت تا با برادران مسلمان خود كـهـ در مدينـهُ منـوره

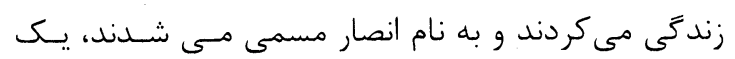
جا شوند. انـصار مهرباجرين رادر بــين خــود جــا داده و حسضرت

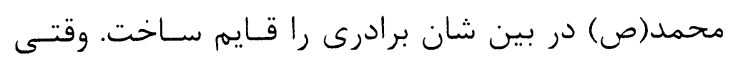

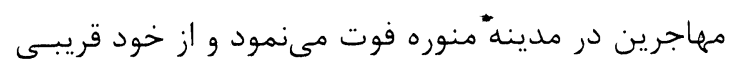
كه با وى به مدينه منوره هجرت كرده باشد، نمى داشت، انصارى كه با او عقد برادرى بسته بود، مستحق ميراث او

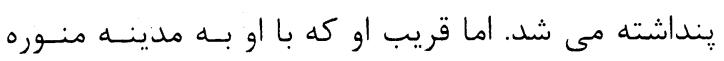
هجرت نكرده بود و در مكه مكرمه زندَّى مى كـرد؛ اخـر جه مومن همم مِىبود مستحق ميراث متوفى نمى جنانجه اين موضوع را خداوند تبارك و تعالى در اين آيه

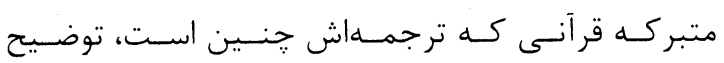
مى دارد. اهر آينه آنانى كه ايمان آوردند و هجرت كردند و جهاد

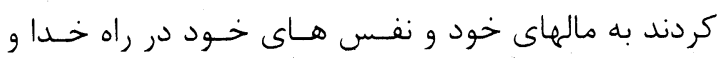
آنانى كه جاى دادند و نصرت كردند اين جماعـه بعضى مآى شان كارسازان بعضى انـد و آنـانى كـهـ ايمـان آوردنــد و
تو، تعرض به من تعرض به تو و من از تو ارث ببرم و تـو از من ارث ببرى، به موجب اين تيمان اين دو نفر بيعانه

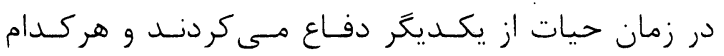
زودتر مىمرد، ديخرى مال او را به ارث مىبرد. زن جزء سهرم الارث

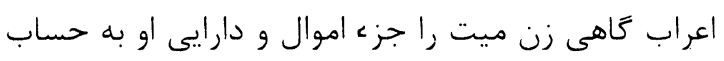

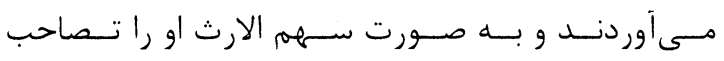
مى كردند. اگر ميت يسرى از زن ديخـر مسى داشـت، آن

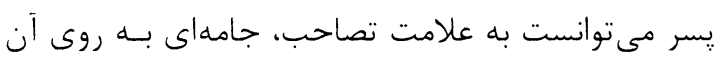

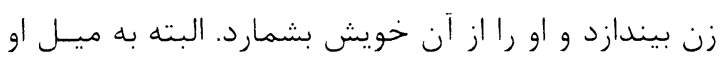
بود كه أن زن را به عقد نكاح خود در آورد و يـا او را بـه ركه زنى به شخص ديخرى بدهد و از مهـر او اسـتفاده كنــد. اين رسم را نيز قرآن شريف منسوخ كرد.

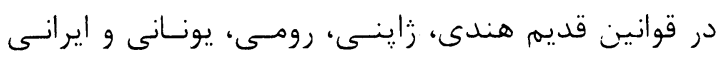

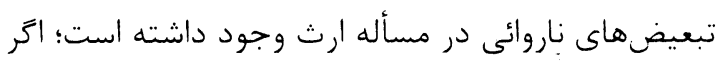

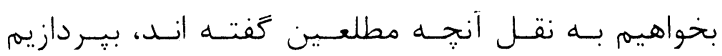
جندين مقاله خواهد شد. اسباب ميراث در صدر اسلام حضرت محمـد(ص) مسى خواسـت مسسلمانان را متحسـد ساخته و يك ملت قوى با عزم باشد كه به كمال عـزم و

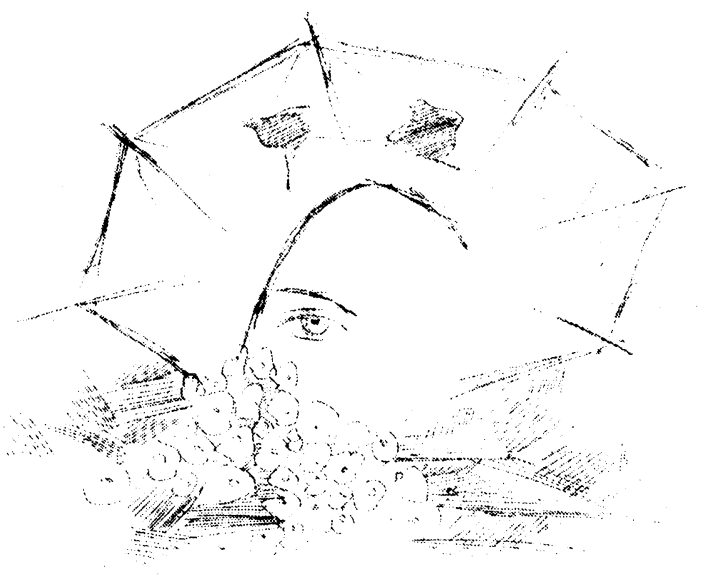


دين اسلام كه خيـر و سـعادت بـشرى و تـامين عـدالت

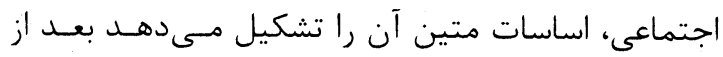
الغاء نظام ميراث زمان جاهليت و آنجـهـ در صـدر اسـلام جهت مصلحتى در اسباب ميراث قرار گرفته بـود، نظـام

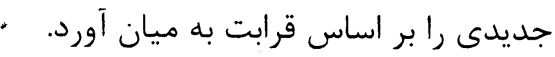

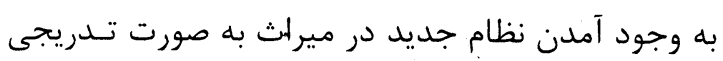

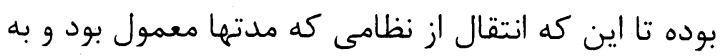

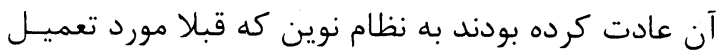

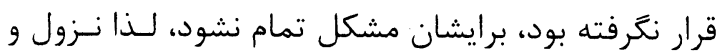

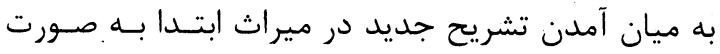

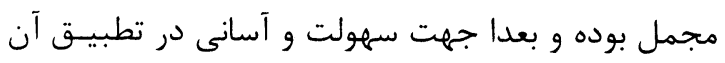
به صورت مفصل نازل كَرديد. خداوند بزرى در آغـاز بـهـ شخصى كه خود را در حالت وفات مىبيند، حـق داد تـا براى والدين و اقاربى كه خواسته باشد به اساس وصسيت

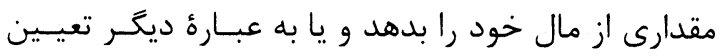

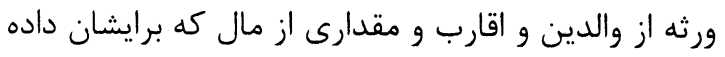

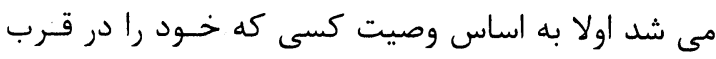

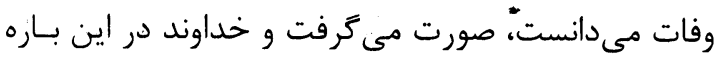

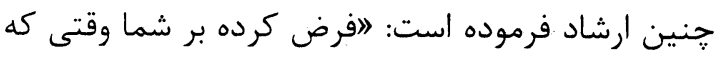

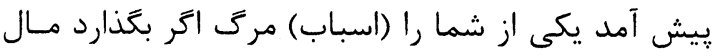

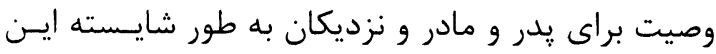
حكم لازم است براى يرهيز

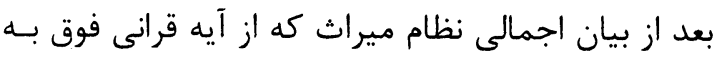
صورت واضح معلوم مىشود، خداوند كريم اجمالى را كه نه نهان

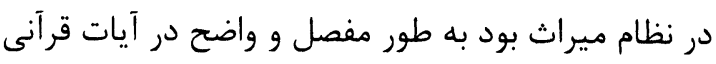

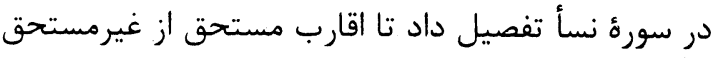

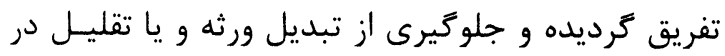
مقدار به عمل آيد.

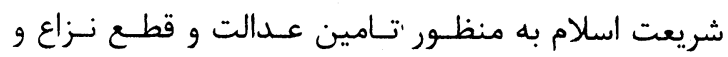
خصومت و رفع اختلافات بين ورثه حصهُ هر كدام ورثـهـ

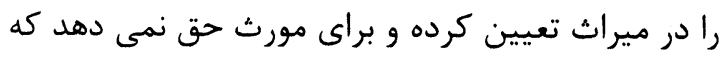

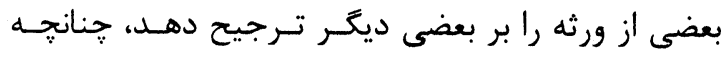

هجرت نكردند نيست شما را از كار سازى ايشان جيـزى

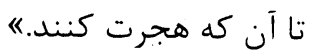

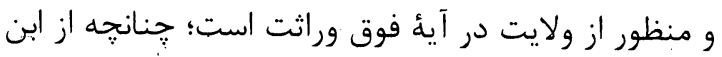

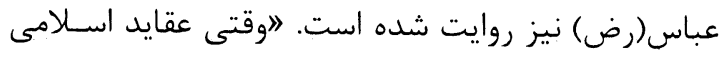

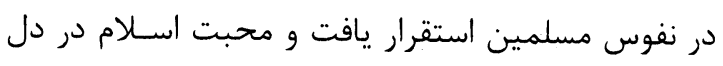
مسلمانان جا گرفت و عمل به تعاليم اسـلامى بالايسشان

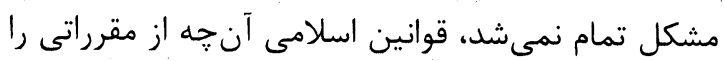

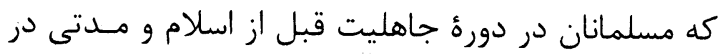
صدر اسلام در ميراث به كارمسىبردنـد، ملفسى قـرار داد.

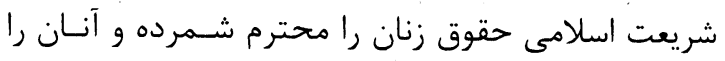

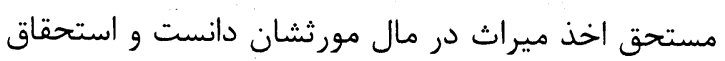

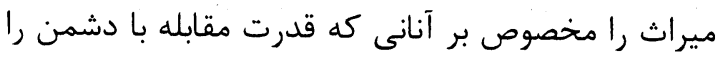

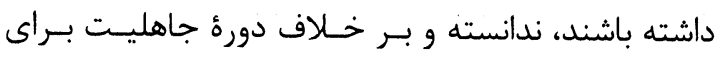

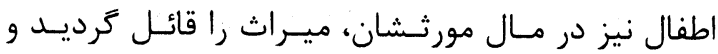

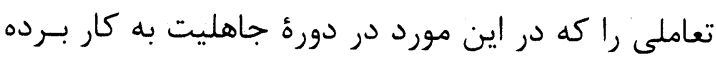

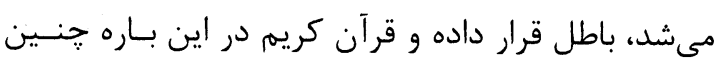

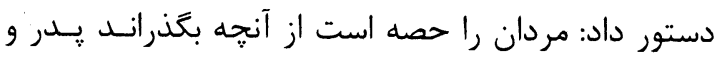

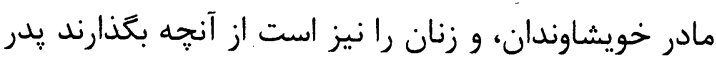

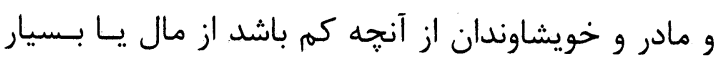
باشد حصه مقرر كرده شده.

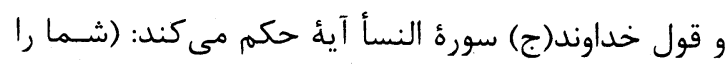

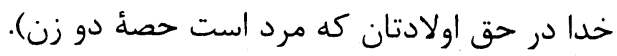

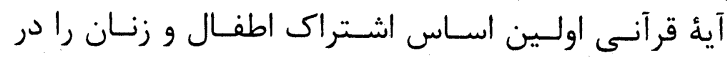

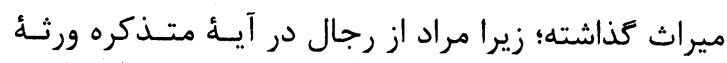

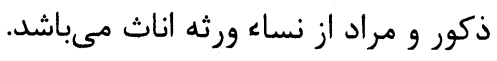

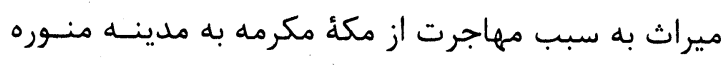

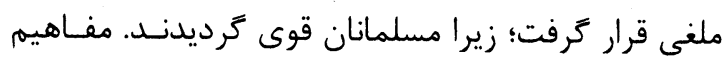

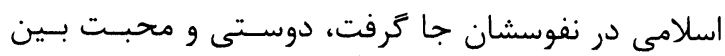

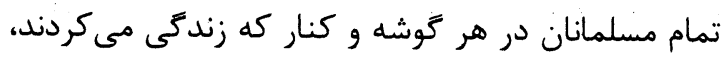

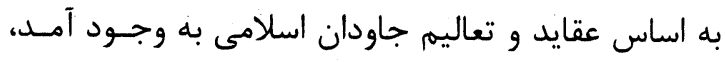

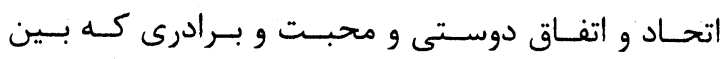
مهاجرين و انصار كه يكى از اسباب ميراث درصدر اسلام

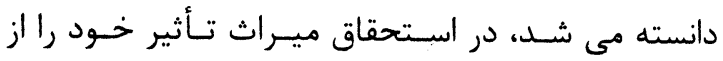
دست داده و از اسباب ميراث قرار نتخرفت. دران.

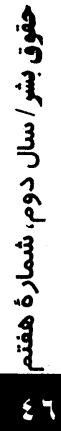


و به اين اساس مرد و زن را در حقوق اكتـساب ملكيـت،

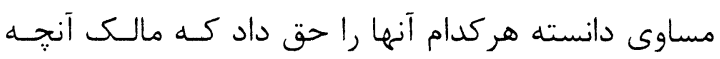
شوند كه كسب نموده اند. به اساس ثبوت حـق ملكيـت براى زنان حق ميراث در مال مورثـشان نيـز داده شـده، زيرا ميراث يكى از اسباب اكتساب ملكيت بـوده و فـوت

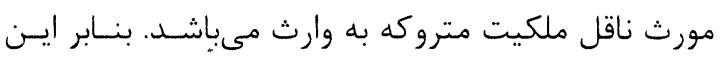
زن و مرد در اصل استحقاق ميراث مساوى هستند.

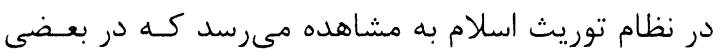
حالات جون تعصيب يعنى در حالتى كه خــواهر و بــرادر از جمله ورثه متوفى قرار گرفته و هر دو مستحق ميراث دانسته شوند، طورى كه از اين آئ كريمه "احكم مى كند

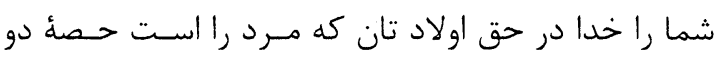

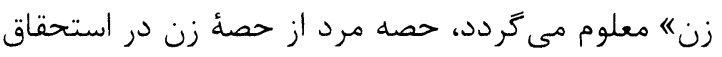

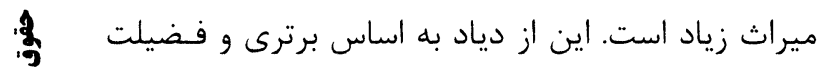

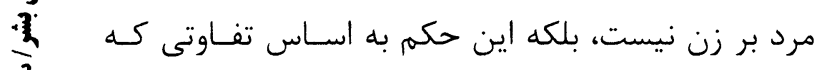

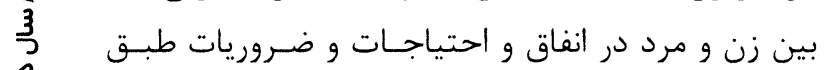

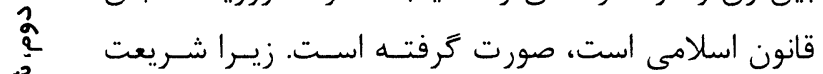
ลุ.

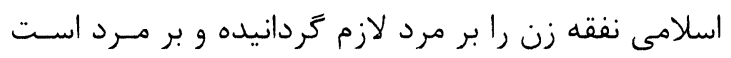

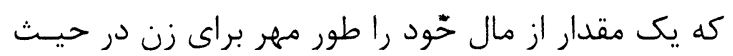

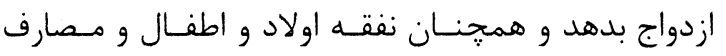
تعليمى آن و تهيه مسكن و لــوازم منـزل بــهـ دوش مسرد

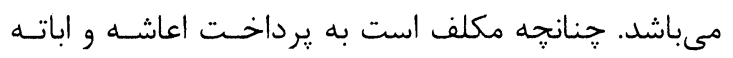

زوج را از ميراث زوجه و زوجه را از ميـراث زوج محسروم نساخته و براى هـر كدامسشان حسهُ معينـى در ميــراث تعيين نموده اسـت و زنـان را مـستحق ميـراث در مـال

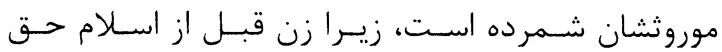
ميراث و ملكيت را نداشت و با او به حيسث مـال و متـاع معامله صورت مى زرفت، به ازدواج مجبور زردانيده شده و به ميراث برده مىشد. نه تنها برايشان حـق در ميــراث داده نمىشد؛ بلكه مطلقا حق مالكيت را نداشـتند و اخـر احيانا مالك جيزى هم مىشدند نمىتوانستند بدون اذن

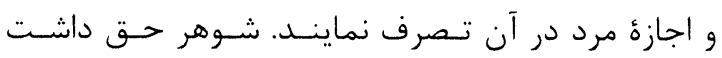

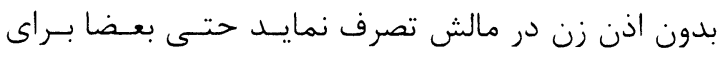
مرد حق داده شده بود كه دخترش را به فروش برسـاند.

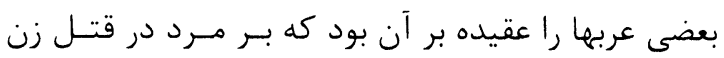
قصاص و ديت لازم نمى وقتى دين اسلام به ميان آمد، تمام بى عـدالتى هـايى ردئ

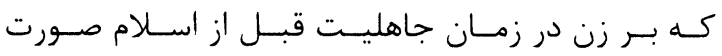
مى مردان ثابت ساخت، در اين مورد خداوند بزرگ در سورة

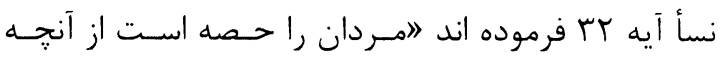
اكتساب كرده اند و زنان را حصه است از آنجـهـ اكتـساب كرده اند و سوال كنيد به جانب الهى از بخشايش اوه.
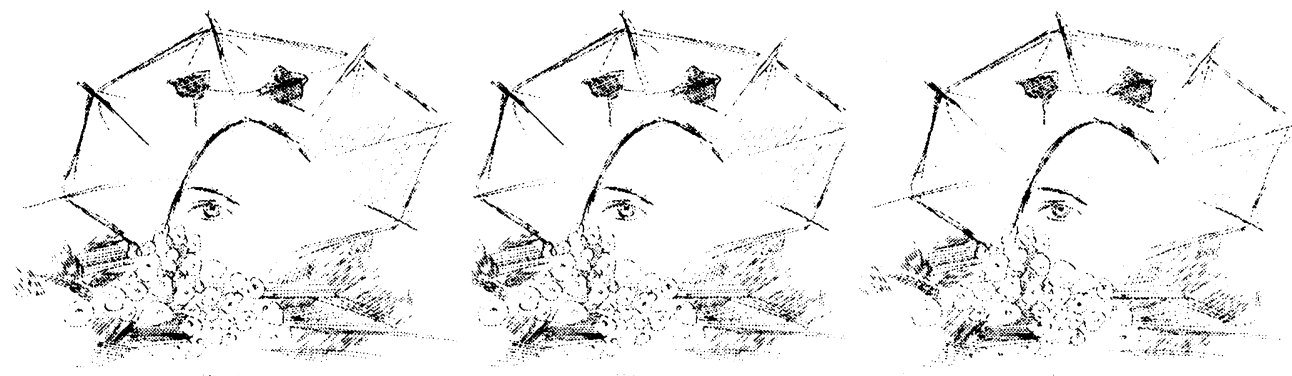
فاميل خويش دارند، نظر اندازند از ازين ادعا صـرف نظـر خواهند كرد.

از آنجه كَفتيم به وضاحت معلوم مـى شبـود كـهـ تنفـيض

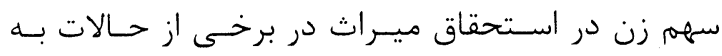

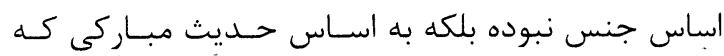

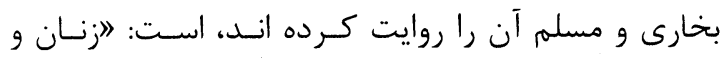

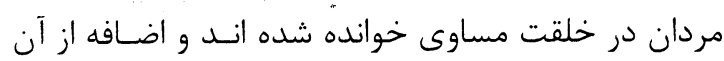
اين كه زن بـا وصـف ايسـن كـه مـادر اسـت در شـريعت

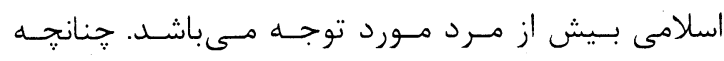
حضرت محمد(ص) بـراى كسىى كـهـ در مـورد احسـان كردن به والـدين از ايـشان ترسـيدند: جنــين فرمودنـد:

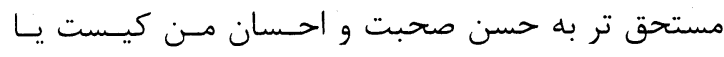
رسول الله؟ حضرت رسول اكرم فرمودند: مـادرت. تفـت بعد از آن كه مستحق تر است، حضرت ييامبر فرمودنـد: مادرت. كفت: بعد از آن كه مستحق تر است؟ فرمودنـد: مادرت. كفت بعد از آن كه مـستحقتر كيسست؟ حسضرت ييامبر فرمودند: يدرت يعنى به آن شخص امسر نمـود تـا

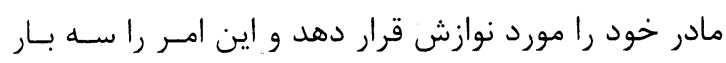

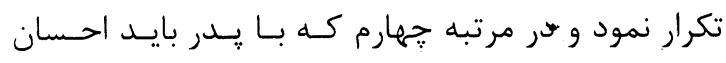
نمايد. از حديث نبوى فوق به خوبى معلوم مى گردد كـهـ زن در اسلام موقف و منزلت خاصى داشته و اهتمامى كه راجع به زنان در شريعت اسلامى به ميان آمده در اديان سابقه و شرائع قبلى نظيرى نداشته است.

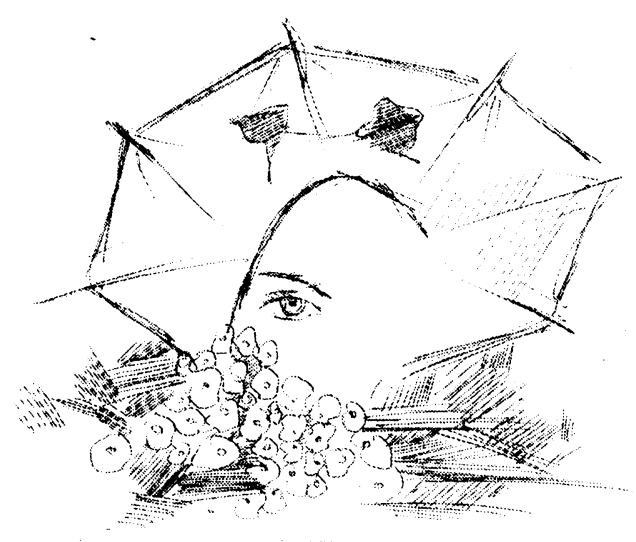

يدر و اقارب در صورتى كه فقير باشند؛ اما زن مكلف بـه يرداخت مصارف خود و اولاد و اطفال و اقارب نادار طبق موازين اسلامى نيست؛ لذا شريعت اسلامى در اسـتحقاق ميراث او را.|ز نغاه جنس مورد نظر قرار نداده؛ بلكه با در نظر داشت مكلفيتها و مسؤوليتهاى اقتصادى كـه دارد،

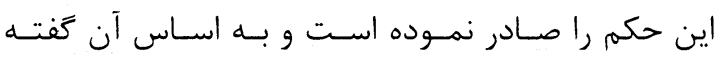

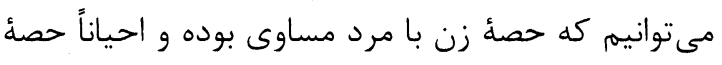
زن از حصهُ مرد اضافه مىباشد. مثلا اتر شخـصى وفـات

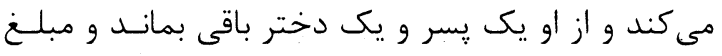
شش هزار افغانى متروكه داشته باشد، جهار هزار افغـانى

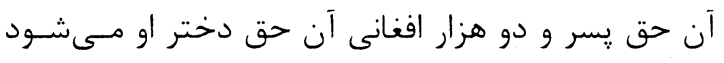
كه يسر در صورت ازدواج مجبور است به اسـاس قـوانين

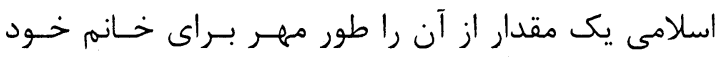
بدهد؛ اگر جه زوجهاش غنى هم باشد و از جـانبى تهيـهـ

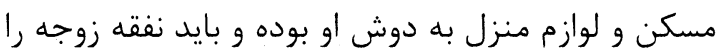

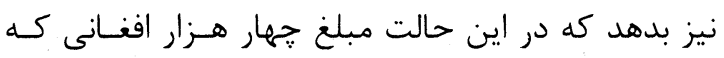
طور ميراث از يدر به او و خانمش ارتباط مى خيرد و اتــر

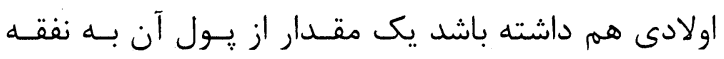

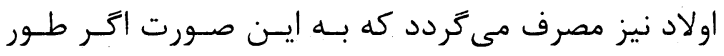

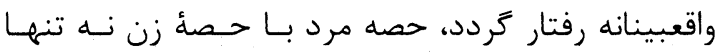

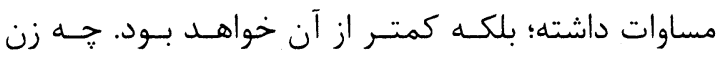
طبيعى است كه ازدواج خواهد نمود و يكى مقدار مسال رال طور مهر از شوهر خود گرفتـه، نفقـهـه و مـصارف اولادش نيز به دوش شوهرش مي باشد. اما مبلغ دو هزار افغانى را

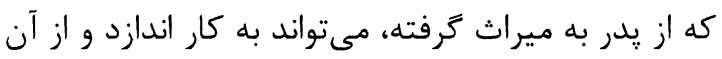

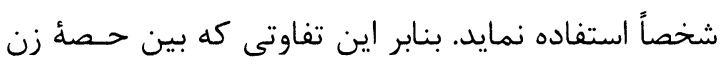
و مرد در حصه استحقاق ميراث در بعضى حسالات ديـده مىشود، بى عدالتى محسوب نمى گردد، زيـرا تكـاليف و احتياجات مرد طبق قانون اسلامى نظر به احتياجات زن

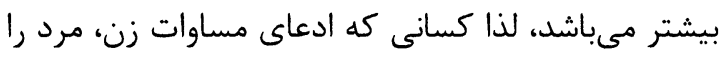
در ميراث با تفاوتى كه در انفاق و احتياجات بـين شـان

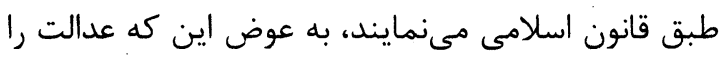
در جامعه اسلامى برقرار سازند، طالب ظلم مىشوند. من

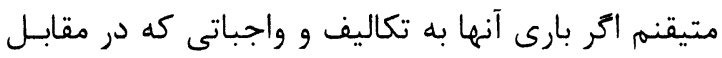




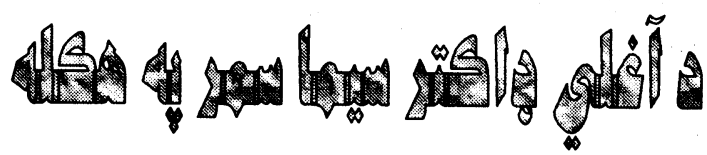

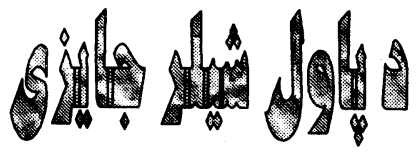

\section{واكتر گريتّ هالر د برن بنار :}

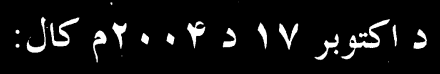

زبارونكى: ا.م.هل

آغلى سيما سمر خيل تولى هختى دب تسه متوجسه كـري

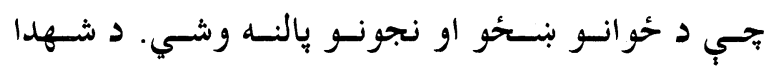

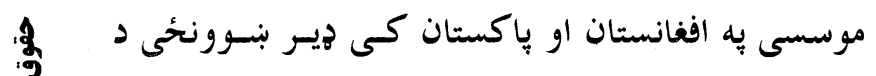

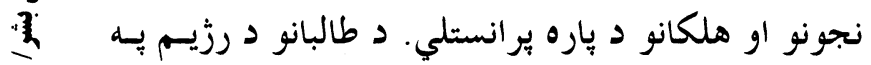
3 a

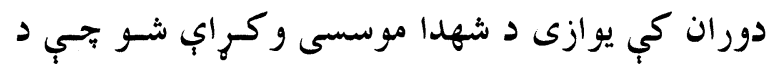
افغانستان بِه مركزي برخو كي نجونسو بنسوونحُى فعالـه

\section{وساتي.}

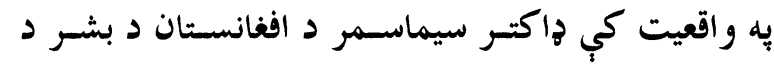
حقوقو دخيلواكى كميسيون مشره دخيلو هخو يوه عالى نمونه ده. د بشر حقوق د انسسانانو دواره جنسسه(نسر او

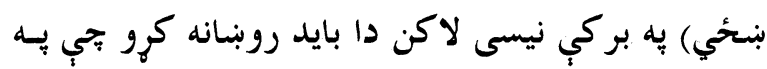

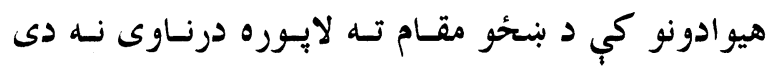

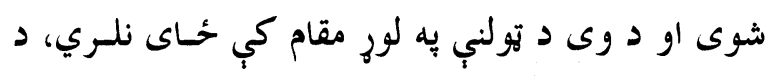

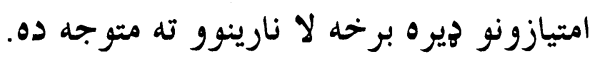
كه به تولنو كي يوه دوله خيل امتياز د نسورو د امتيـاز نسه

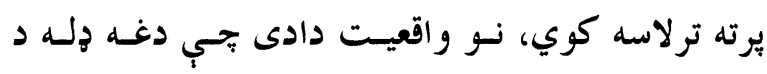

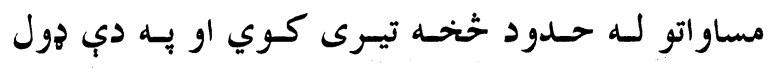
بشري حقوق تر بِبنو كي.بي او د بشر د كرامت درناوي نه كيوي.
د بِاول شيلر موسسه وياري جب آغلى هُاكتر سيماسسمر

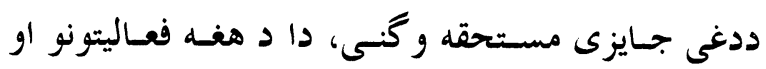
هخو محصول دى كوم بجي دغسه آغلـى د دواكتـرى بـهـ

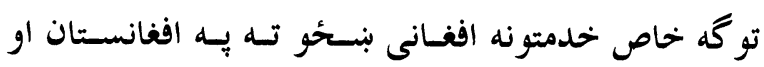

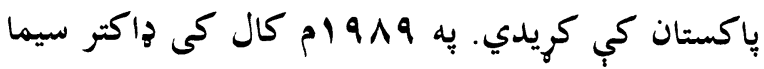
سمر د شهدا موسسه برانستله جي به دوارو هيوادونسو،

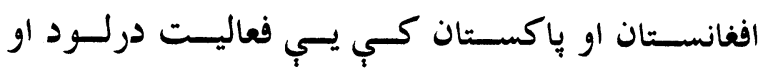

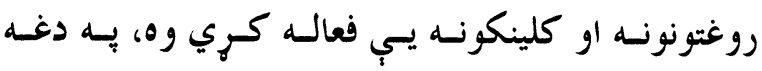
كلنيكونو كي يوازى د بنسخو سره د دوى د نساروغى بـهـ هكله مرستى نه كيدلى بلكى دهغى ترخنكـه دوى تسه د

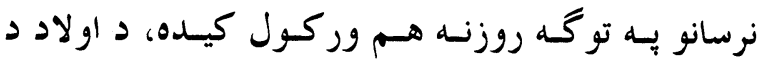

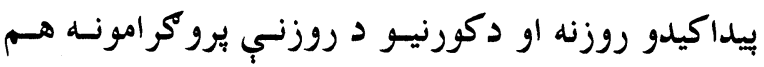
ورته ور كول كيده. تجي دهغه لكبنت او روزنه د شهمدا دوزي

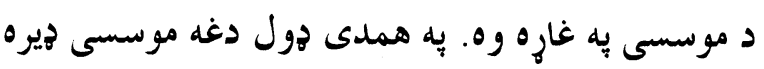

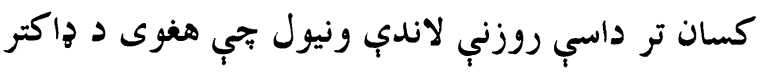

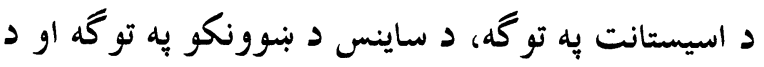
بيرنيسو حسالتونو د روزنسي او خــارونكو يسه تو خــه كـار وكري. 
خدمت منى ندى را نغاري بلكى دهغه ترخنكه به عملى ذّگر كي هير خدمتونه سرته رسولى دي، به دى لحاظ له

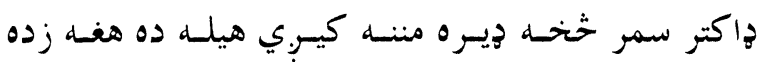
كوونكى تجي، بـه دغسو موسسو كسى زده كـري كسوي

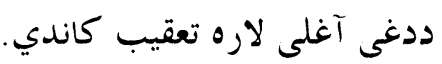

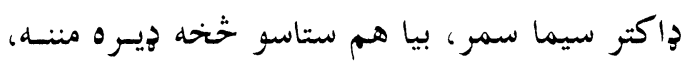

موب. مننه كوو بجي تاسو زيرى هخثى سرته رسولى دي او

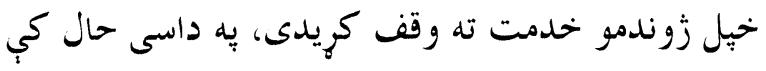

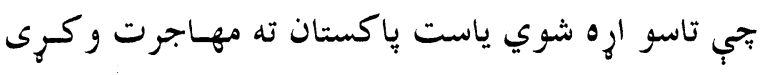

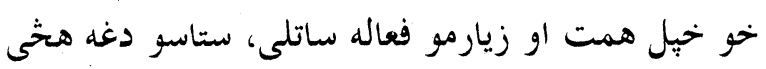

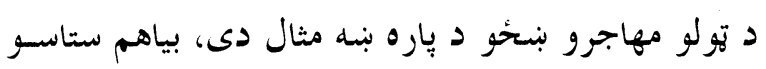

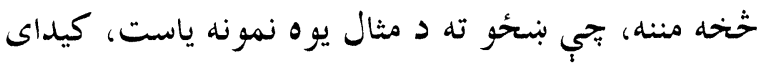
شى جب تولى بنسئى ستاسو د دغو سختو هلو خحلو خخه

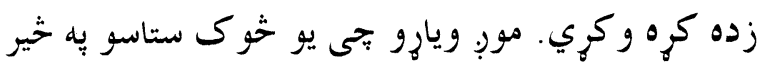
شته جى ددغو ستاينو وري وي، مورب. هيله لرو بـى تاسـو

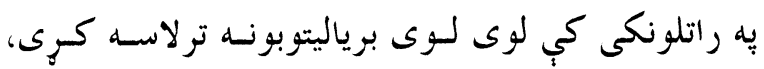

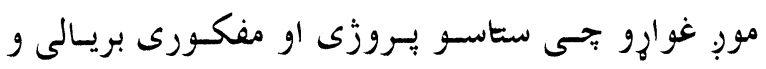

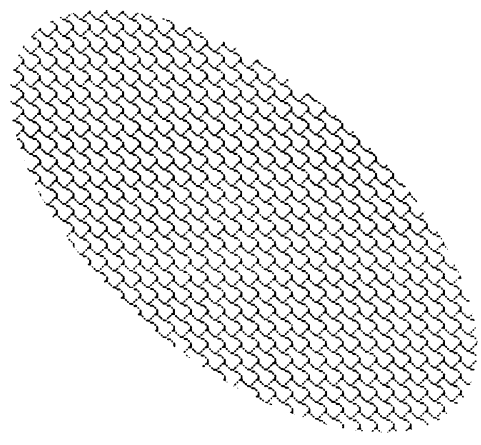

كيداب شي تجي انسانان يِ مختلفو نزادونو يورى اره ولري، د جلامذهبونو بيروان وي، يه جلا زبو خبرى و كري، يورى مختلفو جنسونو (نارينه او بنحئهن) امله دوى مساوى دي 
تولد نغرديده اند، درمورد ازدواج شان از جانب والدين تصميم گرفته مى شود. زمانى كه طفل تولد شده اگر آر

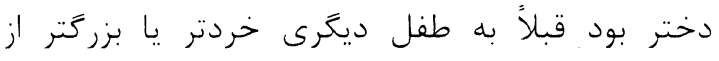

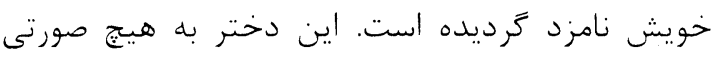
يس از اين كه به بلوغ فزيكى و عقلى خويش مى رسى رسد،

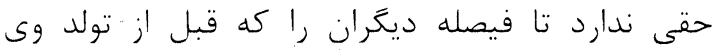

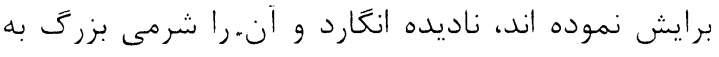

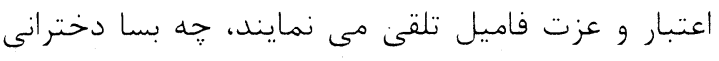
كه به همين ترتيب به عقد مردانى درآمده اند كه نه تصميمى در اين عقد داشته اند و نه هم رضايتى. ازدواج

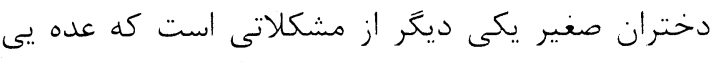

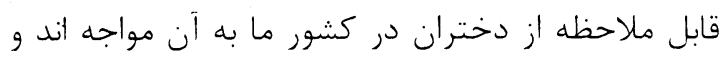

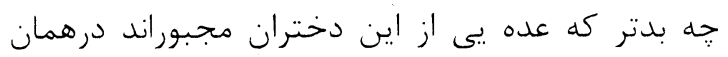

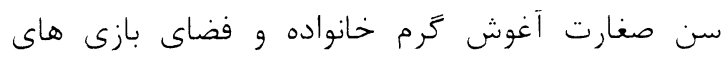

كودكانه خويش را ترك نموده و منحيث زنى خانه دار مسؤوليت بخيرند. با اسباب بازى و عالم كودكانه شان

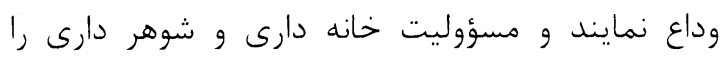
عهده دار شوند .

بدبخت دخترانى كه حتى در همين سن صغارت در خانه شوهر مورد استفاده جنسى نيز قرار گرفته اند. آيا نبايد اين را خشونت مشهود تلقى كرد كه دخترى در صغارت مجبور مى شود كه به خانه شوهر برود و يا احيانأ در صغارت مورد استفاده جنسى قرار زيرد؟ در كشور ما اكثراً رواج براينست كه حين ازدواج از يكى هورديك جانب كه زن است، مشوره صورت نمى كيرد و تنها والدين اند كه تصميهم مى گيرند و حتى هيج اهميتى به رنه نظر دختران شان نمى دهند. هرجند گَاهى اين امر در

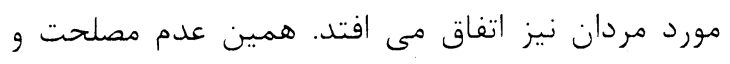

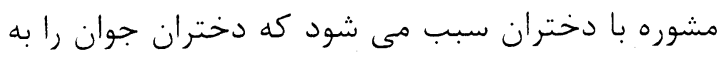

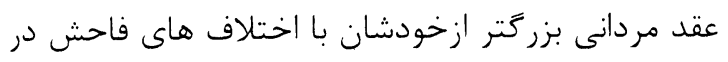

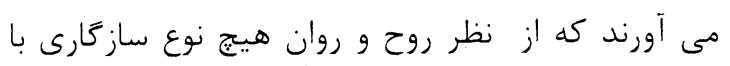

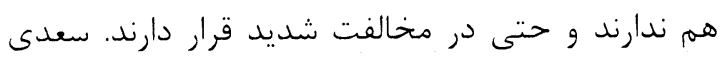
عليه الرحمه درين مورد سخن زيبايى دارد كه مى زويد

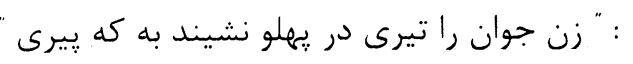
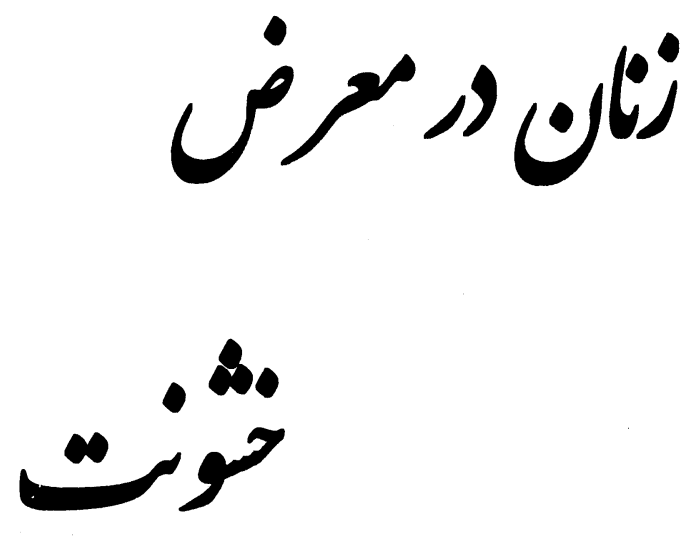

ם سيد عبدالقادر رحيمى سي

خشونت عليه زنان يديده اي نو نيست و ريشه در اعماق

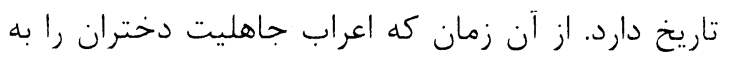
جرم دختر بودن زنده به تور مي كردند تا امروز كه قرن زئ

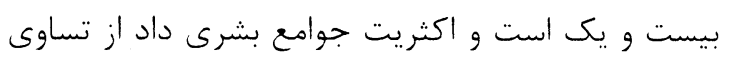

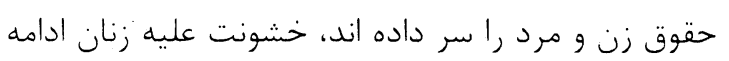

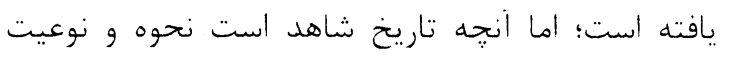
خشونت است كه از زمانى تا زمان ديگر فرق كرده است.

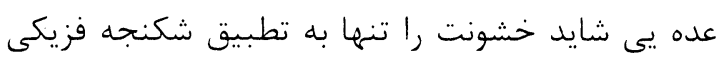

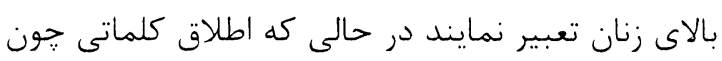

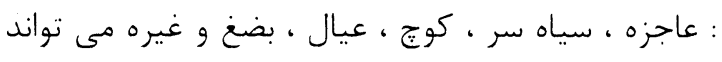

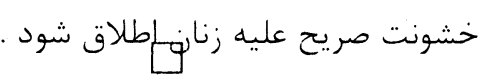

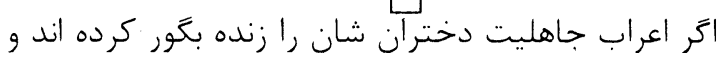

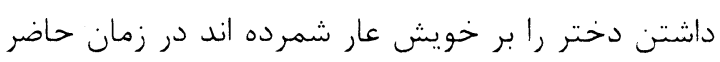

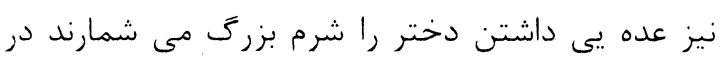

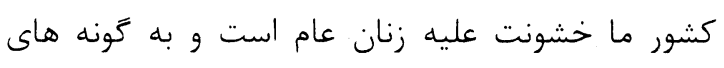
مختلف تطبيق مى گردد. عنعنات رايج در كشور ما كه بايد آن را عنعنه نايسند تلقى كرد زمينه ساز خشونت

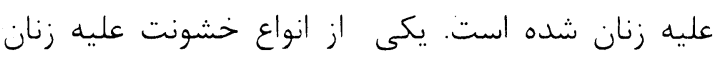

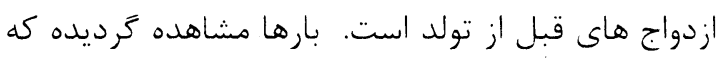
در گوشه و كنار اين كشور :ههناور اطفالى كه تا هنوز 
تعدد اولاد را نيز بايد نوعى از خشونت تلقى كرد كه در

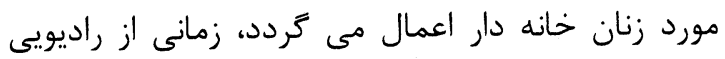

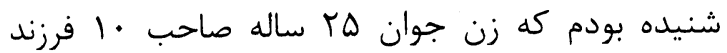
بوده است. اگر اندكى دقيق شويم خانم مذكور از اول

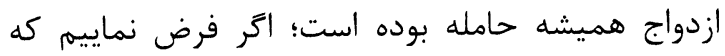
اولين باردارى موصوف در تهبارده سالخى اتفاق افتاده

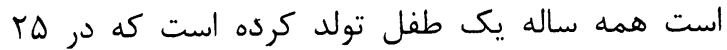
سالگى صاحب • ا فرزند بوده است. از يك جانب تحمل دوران حاملگى مشكل كلى براى زنان است بخصوص در شرايط كشور ما كه هيج نوع حمايتى در ايام باردارى از

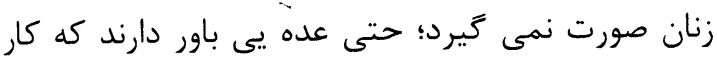

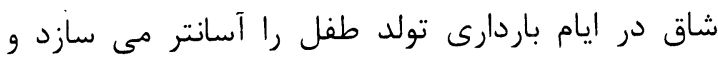
زنان باردار را' تشويق مى نمايند تا در زمان بارداردارى بارى به كارهاى سنگين و شاق بيشتر اشتراك نمايند تا در زمان ران وضع حمل تكليف نيابند. بجه دارى و تربيه طفل و آن هم شير به شير و يى هم، خود مشكل كلى براى زنان است بخصوص در شرايطى كه در كشور ما هيج مرجع و محلى نيست كه مادران اطفال شان را جهت يرورش به به له آنجا بفرستند.

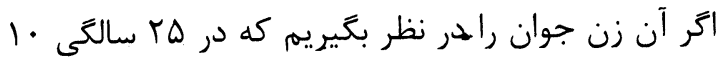

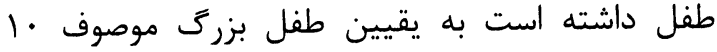

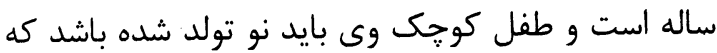
هم اطفال از نو تولد تا ده ساله به مراقبت جدى نيل نياز دارند و نمى توانند خودشان به خود كمك نمايند. از جانب ديخر اين خانم همواره يس از ازدواج حامله بوده

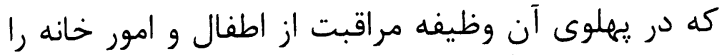
عهده دار بوده است. كثيرى از مرگ و مير زنان جوان مران كه در جريان وضع حمل تلف مى شوند همين خانمهايى اند

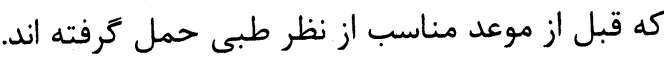

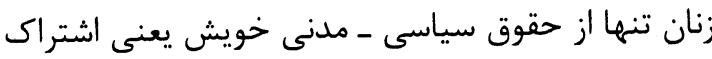
در امور كشورى، اتخاذ تصاميم و اظهار وجود اجتماعى سنى سنى محروم نشده اند، بلكه عده يیى از حقوق شرعى خويش كه همه بدان معتقديم نيز محروم گثته اند. زمانى كه يك خانم از بهره ميراثش بنابر رسوم و عنعنات محروم مى شود ولو اگر سخت محتاج نيز باشد، كجا مى توان يقيين كرد كه در مورد حقوق ديگر عدالت آن تامين
كاهى زنين ازدواجهايى به طلاق و جدايى كشيده و دوام نياورده است. بدتر اين كه هركاه دخترانى نخواسته اند تن به ادامه خشونت دهند و خواهان مقاطعه ازدواج كرديده اند، إز جانب فاميل خود، فاميل شوهر و هم اجتماع، مورد سرزنش قرار گرفته اند و حتى ديگر به عنوان زن طلاق شده نتوانسته اند تجديد ازدواج نمايند و تا اخير عمر به تنهايى به سر برده اند و به جشهم

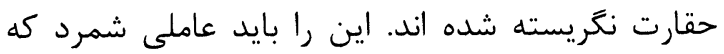
عده يى از زنان با آن كه هيج علاقمندى به به ادامه زنده

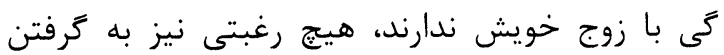
طلاق نشان نمى دهند. تاهى هم خودسوزى، خودكشى ريى و امراض روحى از همين امر ناشى شده است. لت وهم وهند كوب و تحقير نمونه بارز ديگرى از شكنجه است كه در كشور ما بدبختانه به كثرت رايج است؛ اتر ارزيابى دقيق صورت گيرد، كثيرى از زنان خانه دار مورد لت و كوب شوهر و حتى اعضاى فاميل شوهر قرار گرفته اند. لت و و موردئ كوب تا حدى رايج گشته است كه در بعضى از نقاط كشور لت و كوب به عنوان حق مسلم شوهر شناخته شده و هيج مانعى براى شوهر وجود ندارد، اگر خانمش بـ را مورد لت و كوب قرار دهد. عدم مشاركت زنان در امور اقتصادى خانواده گاهى زنان را به عنوان عناصرى مصرفى و طفيلى در خانواده تلقى كرده است حتى در بعضى يا كثيرى از خانواده ها زنان

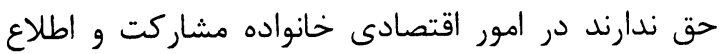
داشته باشند. ديده و شنيده ام شوهرانى را كه هيج به زنان شان اجازه نداده و نمى دهند كه خانم از شوهر بيرسد عايدت جند است؟ از جهه مدركى عوايد دارى و و وانه يا جى كارى انجام مى دهى تا يول به دست آورى؟ آر خانمى تصادفى يا جسورانه جنين سوالى را مطرح

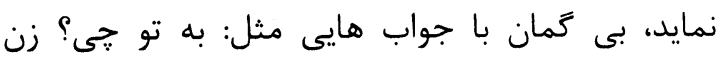

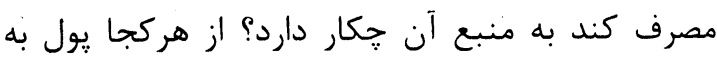
دست آوردم از خانواده ات نخواهم زرفت، مواجهيه خواهند بود. اين بدان معنى است كه زنان حق ندارند در

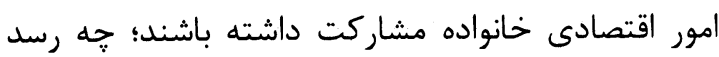
كه در مورد تصميم بخيرند و يا نظر ارائه نمايند. 
اين امر متعصبانه برخورد نمايد. از جانب ديگر اتر از ازدواج هاى اجبارى بحذريم زاهى اتفاق مى مى افتد كه دختران با رضايت خودشان قبول كرده اند كه خانم دوم مردى باشند؛ شايد خانمى كه يذيرفته خانم دوم مردى ردى باشد، فراموش كرده كه زن ديگرى كه همجنس وى

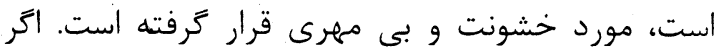

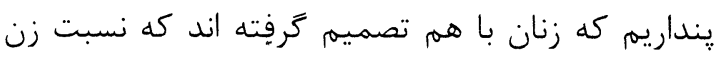
بودن به هم همكار بوده و ديگر به هيج صورتى خانم

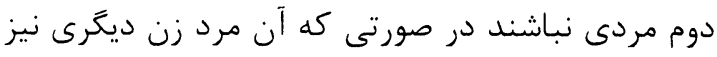

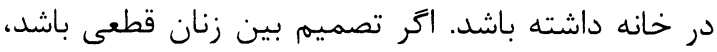

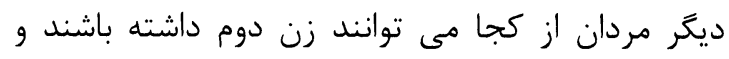
عدالت را ميان زنان شان تامين ننمايند.

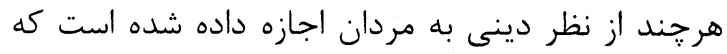

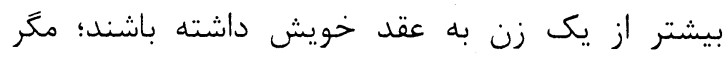
همواره تاكيد دين در تامين عدالت ميان زوجين است، وقتى تاكيد شده كه اگر خطر عدم تامين عدالت است به ديه يكى بسنده كنند. جاى دارد كه منابع قضايى و حقوق

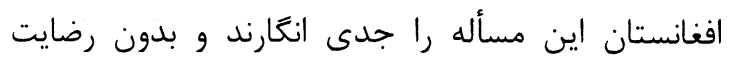

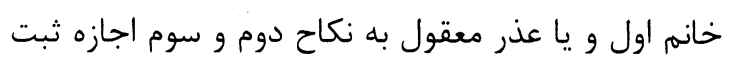

ندهند.

اختلاف عروس و خشو از قديم الايام زبانزد عام است، هيج كس در افغانستان اختلاف عروس و خشو رو ران كه هر دوى شان زن هستند، نمى تواند فراموش كند. بسيار به ديه

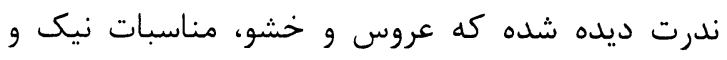
حسنه داشته باشند. فقط معدودى از زنان توانسته اند بر اختلافات شان سريوش بزنند و روابط شان را حسنه بنمايانند.

عروس و خشو هردو زن اند و بايد بنابر زن بودن خويش با همديگر همكارى صميمانه داشته باشند و وردو خشو كه

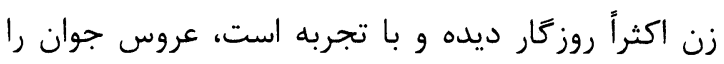

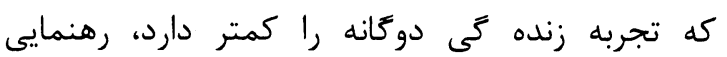

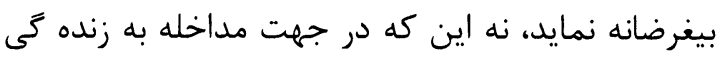
شخصى يكديگر برآمده و از سر عناد با يكديگر رابطه برقرار كنند.
گثته است "در بسا نقاط كشور ما رواج بر اين است كه زنان از خق ميراث محروم مى گردند. خداوند (ج) مردمان را به تحصيل علم تشويق و وتاكيد

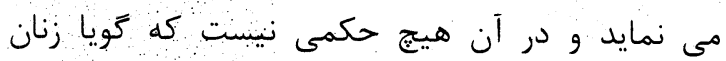

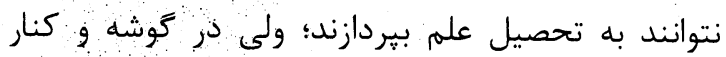

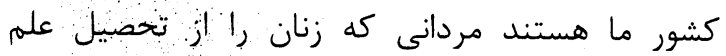

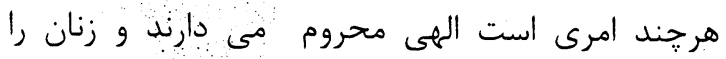
اجازه رفتن به مكاتب نمى دهند. تاسف بار اين كه حتى إنى

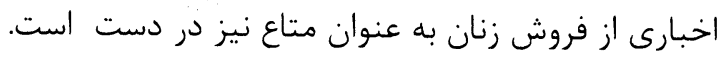
آنجه در فوق كفته شد بيشتر خشونت هايى است كن كه ناشى از رسوم و عنعنات مردم مى باشد و متاسفانه در

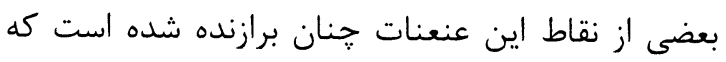
حتى قانون را نيز تحت شعاع خويش قرارداده است.

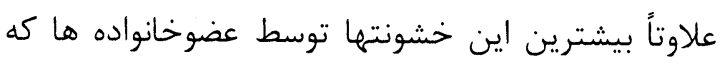
مرد هستند بر زنان روا داشته شده است است . آنجه تا هنوز كمتر به آن يرداخته شده است، خشونت

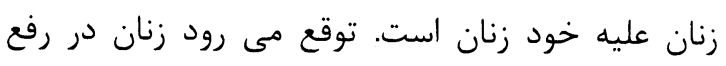

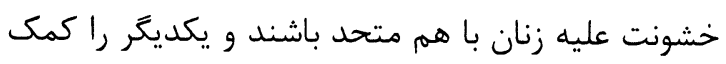

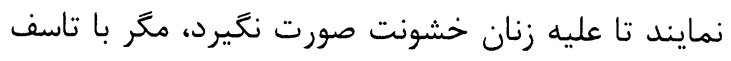

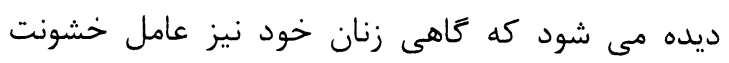
عليه زنان مى باشند. شايد همگى با من متفق الراى باشند كه زنان باردار بار

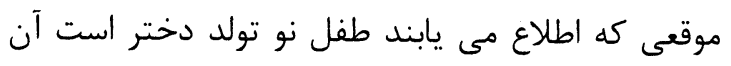

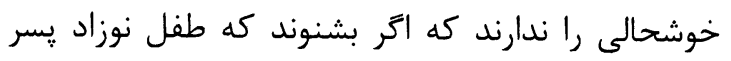

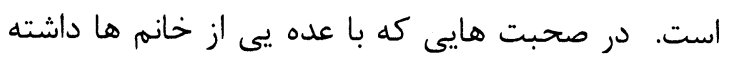

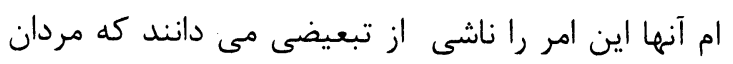

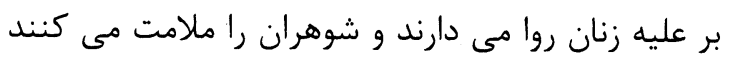
كه از تولد فرزند دختر خوشنود نمى بن باشند بندابر اين

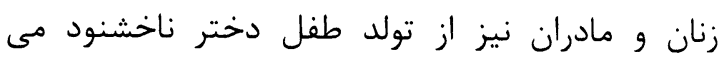
باشند.

رضايت مردان از تولد دختر يا يسر مى تواند روى

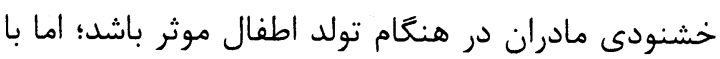
آن هم از زنان و به خصودى مادران در هادران توقع مى رود تا فقط به خاطر زن بودن با طفل نوزاد كه دختر است است توجه داشته و از تولدش خشنود باشند؛ ولو اگر شوهرشان به به بهر بهر 
را مجاز ميدانند كه در اموز دختران خانواده مداخله

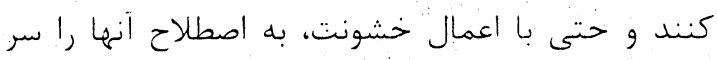
جاى خود شان ينشانند جايى كه براى دختران در ذهنيت افراد ذكور خانوإد تعين شده و ريشه هاي هزاران ساله دارب، فضان بسته خانه است. نعاه "افراد

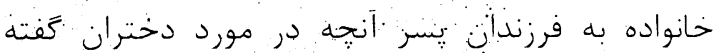
شده متفاوت اسبت و در نتيجه فضتاى خانه. بدرى براى رشد شخصيت و أبتماد به نفس يسران و ايجاد روحيه جاه طلبى و مبارزه جويى در آنها متناسب است ، يسران نوجوان تمام طبقات اجتماعى مى توانند در هر ساعتى فراغت شان را با همسالان خود بحذرانند. درين. قلمرو گَترده است كه پسران زندگى اجتماعى را در مجموعه اى از مبارزه، رقابت، جاه طلبى، دوستى، جنگ و صلح

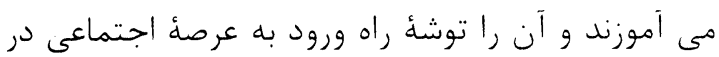
سنين جوانى قرار مى دهند. اين قلمرو وسيع آزادى در انحصار يسران است متاسفانه دختران ازين نوع آزادى ها محروم اند. ديگر اينكه فرزندان دختر، در همسر زَينى نيز همـواره در معرض خشوت افراد ذكور و حتى اناث خـانواده قـرار دارند و به ويزه در خانواده هايى كه فقر اقتصادى با فقـر فرهنكَى، يا هردو غالب است، فرزندان دختر اولـين و در دسترس ترين نشانه هاى هـستـند كـه هـدف قـرار مهى كَيرند به سخن ديگر، در جنين شرايطى، دختران زودتــر از يسران قربانى مى شـوند و در معــرض ازدواج اجبـارى

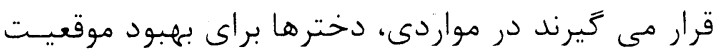
مالى خانواده، در سنين كودكى به افراد سالخورده شوهر مى دهند و شيربها مى گيرند و در مواردى ديگر نيز آنها

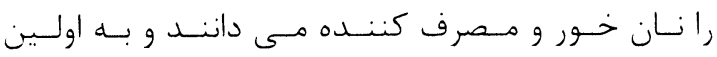

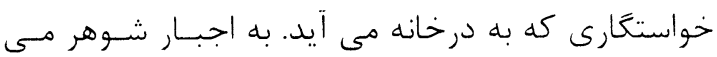

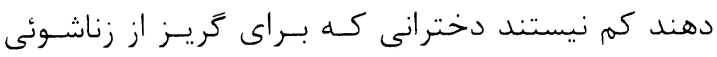
اجبارى دست به خودكشى مى زنند. در اغلـب مسواردى هم كه دختر به زناشويى اجبارى تن مسى دهـد، زنـدىى

ם

خشونتى كه در محيط خانواده به زنان اعمال ميشود به أن "خشونت خانوادگى" مى گويند خشونت خانوادگى "خشونتى است كه در محيط خصوصى به وقوع مى ييوندد و عموماً ميان افرادى رخ ميدهد كه به سبب صميميت، ارتباط خونى يا قانونى به همديگر يِيوند

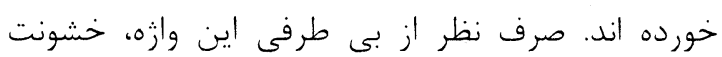
خانوادگى، تقريباً همواره جرم وابسته به "جنسيت خاص" محسوب ميگردد كه مردان به زنان روا مى دارند.

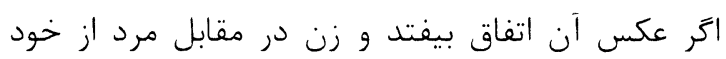
خشونتى نشان دهد، اين رويداد به لحاظ آنكه نادر است

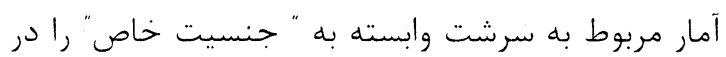

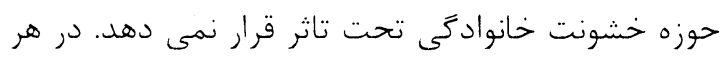
صورت اين وقايع بيشتر زمانى بروز مى كنند كه زن مى كوشد تا در مقابل تجاوز مرد، از لحاظ جنسى از خود

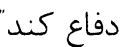
زنان در سراسر دورة زندگى شان جه در خانه يدر جه در خانه همسر متحمل مشكل هاى گَوناگونى از خشونت جنسيتى ميشوند.

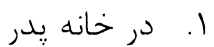
خشونت افراد ذكور در خانواده هاى افغانى براى فرزندان دختر اصل يذيرفته شده اى است. در غياب پيدر، ساير

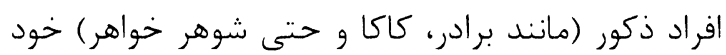


بطور كلى رياست بى قيـد وشـرط مسرد در حـانواده بـه صورت تهديد، ناسزاگويى، تحقير، سـيلى زدن، كنتسرول رفت و آمد هاى دوستانه و خانواده زى. ايججاد محدوديت هاى مالى، تأكيد بر ازدواج اجبارى، ظاهر ميى شـود كــه

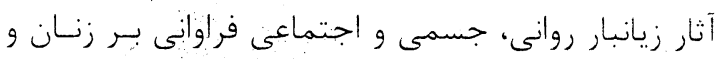

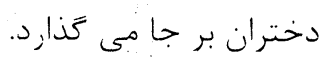

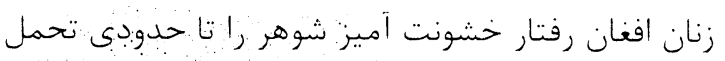
مى كنند و تنها در مواردى كه كازد بـه اسـنتخوان شـان مى رسد، نسبت به آن معترض مـسى شـوند. سـيلى زدن شوهر تقريباً عرف پذيرفته شده اي است كه فقط حسدود

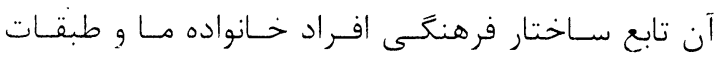
زوناگون اجتماعى و بافت فرهنَى محلى است.

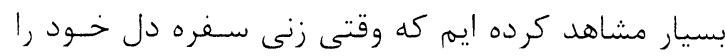

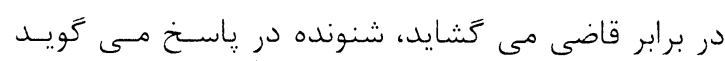

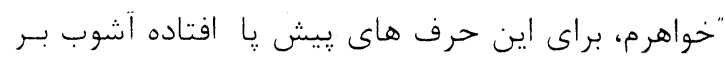

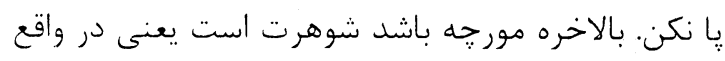

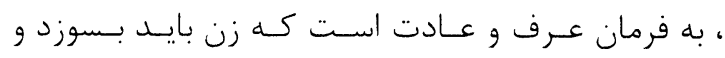

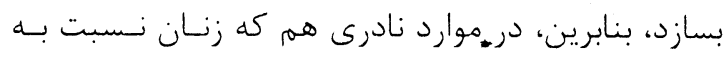

كشور طرح شكايت مى كنند، به نتايج سودمندى دسـت

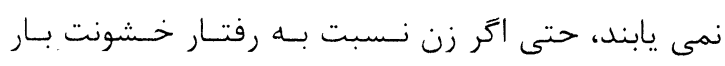
شوهر اعتراض كند و به مراحع قضائى يناه ببــرد، شـوهر

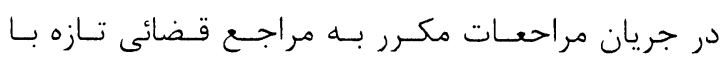
نارسائى ها و كيفيت اجراى قانون آشــا مسى شـود و در در

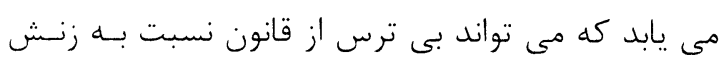
خشونت اعمال كند.
نكبت بارى را تحمل مـى كنــد كـه در برخهى مـوارد بـا

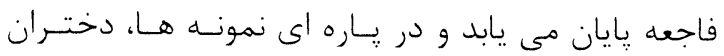
جوان براى فرار از ازدواج اجبارى و ازدواج با فرن دلخـواه

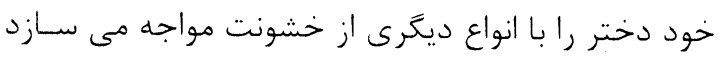
كه به مراتب تلخ تر و مصيبت بارتر از زناشوئى تحميلى ردى بـ

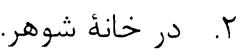
رياست مرد بر خانواده و قدرت وسيع كه قـانون و عـرف

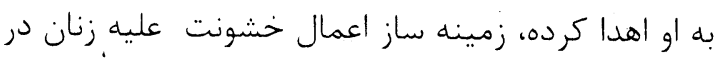

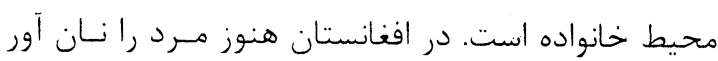
خانواده مى شناسند و هر جند بر شمار زنسان نـان آور و حتى سريرست خانواده افزوده شده، اين تـصور عمـومى مئ همجنان باقى است. مرد در مقـام رئسيس اداره كنـــده و

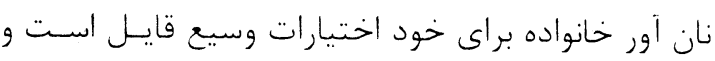
زمينه هاى فرهنگَى، سياسى و اجتماعى جامعـه نيـز بـر

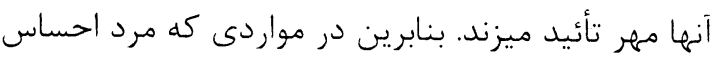
كند شالودة قدرت انحصارى رياستش مورد تهديد اسـت، دست به خشونت جسمى و ورن دياست مرد دير

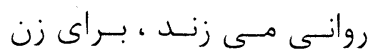

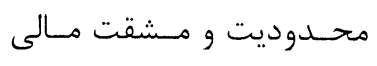
ايجاد مى كند و با اسـتفاده

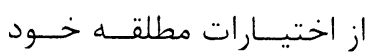
حتى روابط او را با دوسـتان

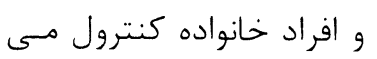
كند، به حدى كه مى توانـد

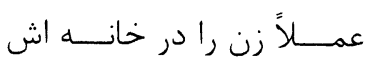
زندانى كند. تأكيد بر ازدواج اجبـــارى فرزنــــان دختــــ، خانواده و قلرت وسيع كه قانون و عرف به او ا زمينه ساز اعمال خشونت عليه زنان در محيط خانواده است. بخصوص زيـر سـنين رشـد، نيز يكى از خشونت هايى است كه مرد در مقابل رياست خانواده بر افراد اناث زير اقتدار خود اعمال مى دارد. 
بجههاى صاحب خانه در زوى حويلى نبودندي نسلام

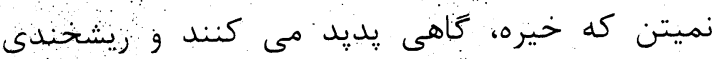

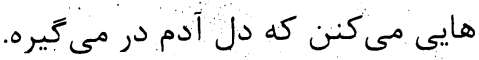

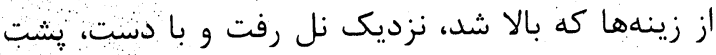

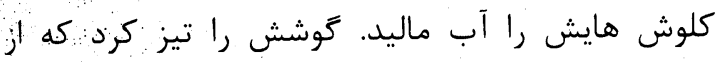
منزل بالا هيج صدايى مىآيد يا نه. لاكن لش نشذ كه

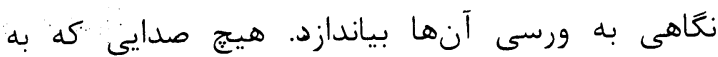

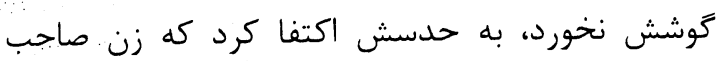

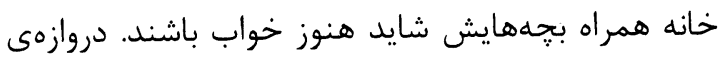

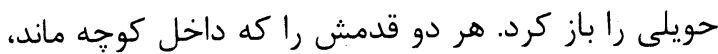
جادرش را روى يِيشانيش كشيد و از داز لبهى آن با دندان هايش ردان محكم كرفت. يِيش از آنكه به دست راست كوجه

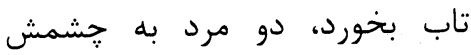

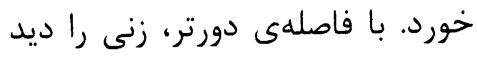

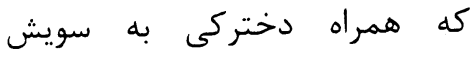

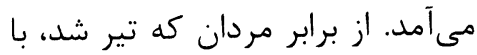

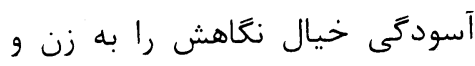

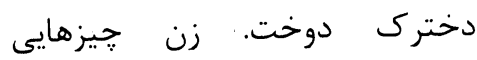

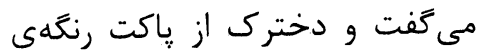
روى دستش هيز هايى در دهانش

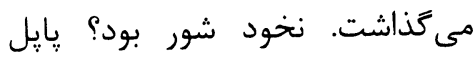
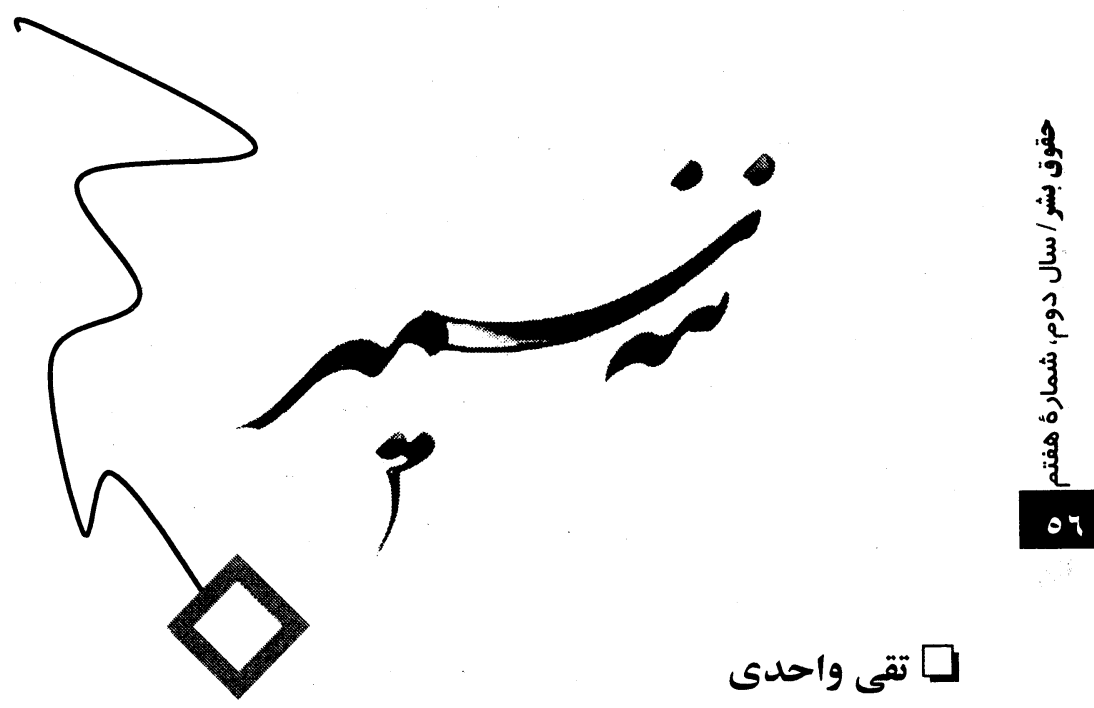
بود؟ نتوانست كه يقين خود را ثابت كند. جه يروا داشت! حسرتى روى دلش را گرفت كه

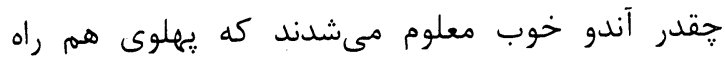

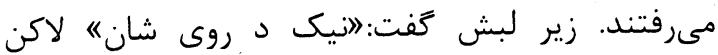

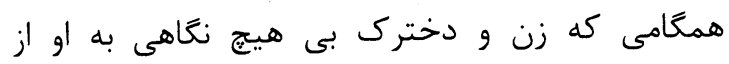

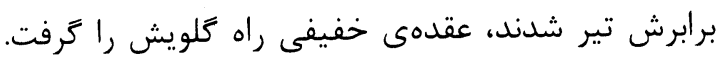

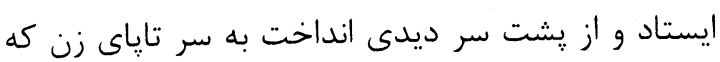

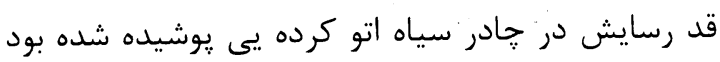
و دخترى كه موهاى بافتهى جلادارش روى جمى جمبرى

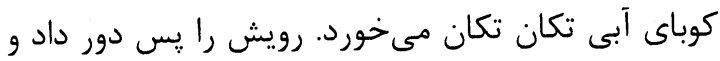

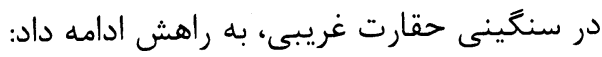

لثه هايئ اينقدر درد خرفته بود كه سير ناكرده مصمم

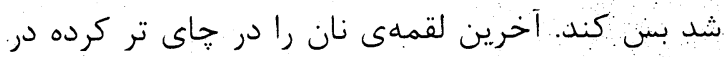

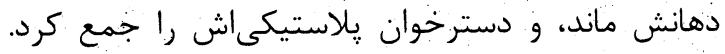

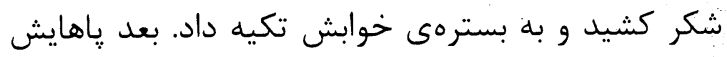

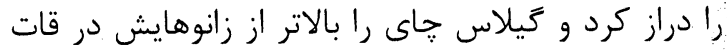

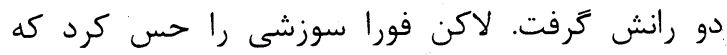

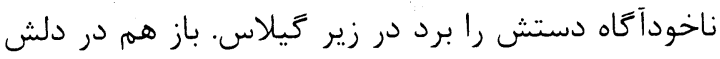

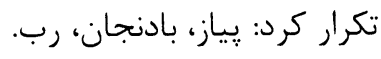

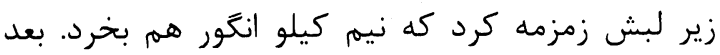

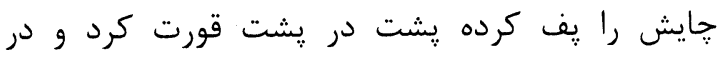


ـ سلاماليك! شكر خدا. شما جطورين، بجهها خوبن، على

احمذ نيامده يس؟ نه سمير اصلا لايق نديد كه در رابطهى شويش جيزى براى حاجى بگويد. موضوع را تغيير داد و گفت: - بفرمايين خانه! و خود را مصروف كرد به باز كردن دروازهى حويلى. حتى التفاتى نكرد كه حاجى شير جگُونه رفت و كدام سو! دلش به شور آمده بود. زمزمه كرد: - جرا رفت كه يس بيايه! غيرت اخر مىداشت نمىرفت. مرا تنهها... كه دروازه باز شد و او را بى اختيار به داخل حويلى

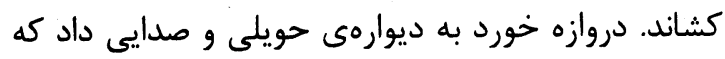
ننه سمير زود جشمانش را به ارسى بالاخانه راست كرد. لاكن ديد نه زن و نه بجهه هايش يشت ورسى معلوم نشدند، قدى از دلهرهاش كاسته شد. گرجه يشت ران

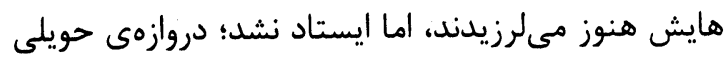
را آهسته بست و رفت دروازهى اتاقش را باز كرد. رفت هيت طرف صندوق. بابه سمير گفت: ـ مه ديگه يايمانده شَّدم. مه ديگه مىروم. ـ ننه سمير جيزى نكفت.

- يك دختر داشتيم كه نامراد شد. تاكى د ملك مردم؟ ننه سمير ياره گَى دامن كتانى كرمى رنگُش را همجنان يينه كرد و نخواست سكوتاش را ميده كند. بابه سمير عصا جوبش رازد روى كليم و فرياد زد: - مى ريم سر ملك خود! ننه سمير بى طاقت شد: ـ د كوه؟ بميرم، نمى روم آنجا. ايقدر سال گذران كرديم، ازين بعد هم خدا مهربان استه.

بابه سمير زد با عصا جوبش به صندوق و خيست از جايش. جنان محكم زد كه كمر صندوق قبقه شد و ننه

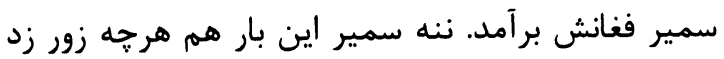
نتوانست آن زا مثل اول راست كند. از يكسو كمرش درد برد

سميرا كه ناله كرد، آهسته زد با جِياق يشت گردنش و كفت:

ـ موهايت را ببافم بد است؟ تا كى بخبل سر بخردى؟

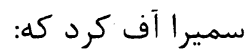

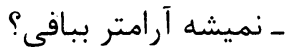
كه طعنه زد: ـ الله كه بهانه گير استى تو هم! قريب شوى كردنى

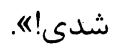
با خود گَفت: ـ موهايش را كه با جكه مىششتم، جلايى پيدا مى كرد كه خوشم مى آمد ببافم، ببافم و طرفش سيل كنه. نرمى موهايش ميان انخشتانم، هوسهاى دلم را تازه مىكرد. نامراد جقدر زبانش تيز شده بود. همو روز ...اف خدا كه جقدر ياد رو شديمم مه. ننه سميرا يس دور خورد طرف خانه و زمزمه كرد: ـ هر روز نيت مى كنم كه ببرم جاب كنهم باز يادم ميره. با شتاب خود را به دهن دروازمى حويلى رساند. كليد را كه به گردنش آويزان بود، از يخن اش بيرون كرد و و

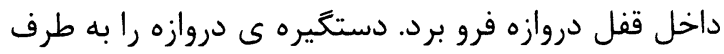

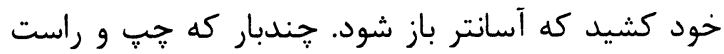
كرد، با يرخاش فروخروده يى كوفت اش را بيرون داد: ـ بلا د يس ازى دروازه شوه الله!

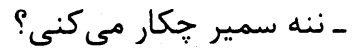
صدايى آشنا لرزش خفيفى بر هيوست بدنش دوانيد. وارخطا رويش را جرخاند. حاجى شير بود كه از

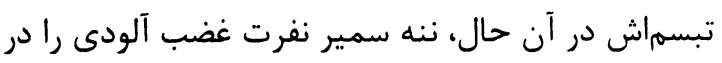
خود حس كرد. به هيج وجه نمى خواست در آن لحظه او را ببيند. صداى حاجى شير برآمد: ـ سلاماليك! جه حال دارين، خوب استين؟ صدايى كه به شكل آزار دهندهيى بلند بود. ننه سمير كفت: 
قاب كند و به ديوار نصب كند و هر لحظه جشمش به او

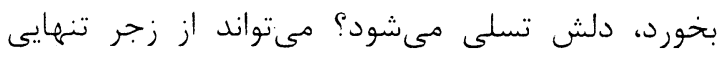

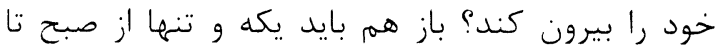

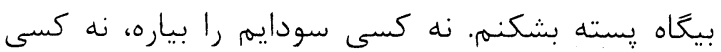

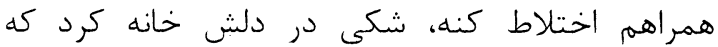

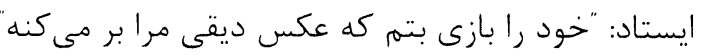

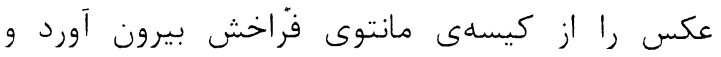

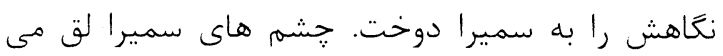

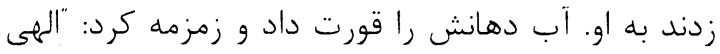
بمرم!" بعد خودش را ملامت كرد: ـ از اين كه ديوانكى كنم و خود كويى كنهم، بهتر استه. شايد دلم آرام بخيره. شايد...

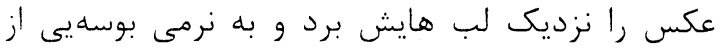

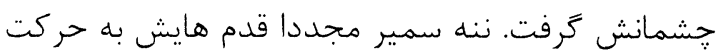

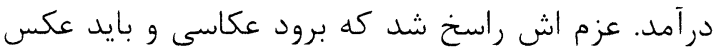

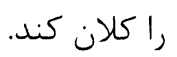

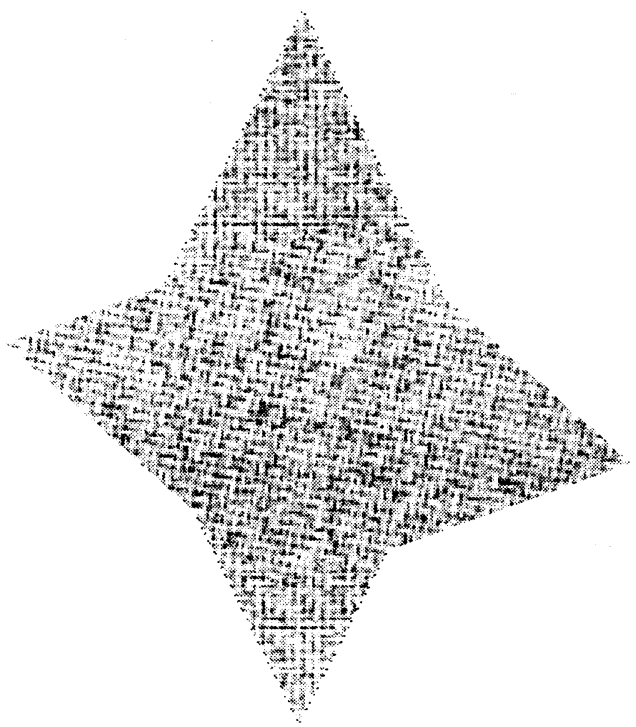

كرفته بود. بى حوصله دروازمى صندوق را بالا كرفت،

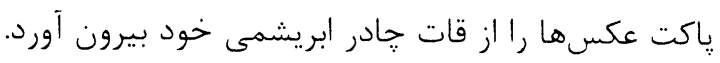

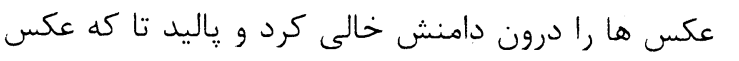

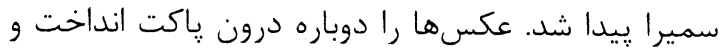

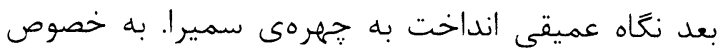

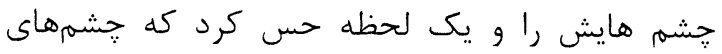

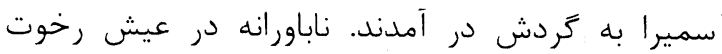
أورى رفت كه رعشهى تلخى زود او را به خود خود آورد.

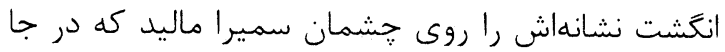

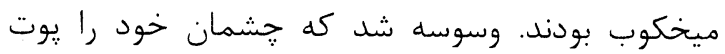
بخيرد كه دوباره خود را در مثل آن لحظه عيشناك آندان

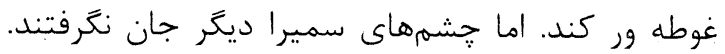

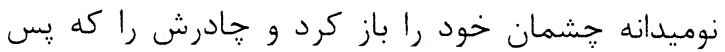

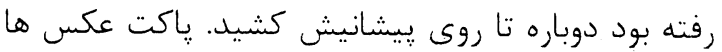

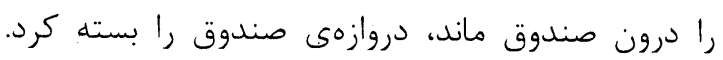

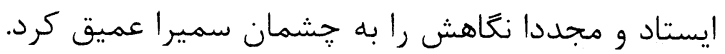

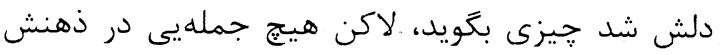

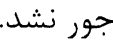
سميرا جشمان آبزده اش را دوخته بود به او. سميرا زير درخت توت لب جوى قشلاق، نلغهاش را در بغل ترفته

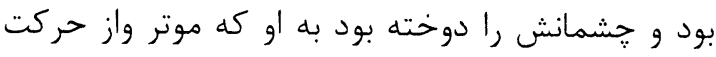
كرد و در كرد و خاك غليظش گمم شد.

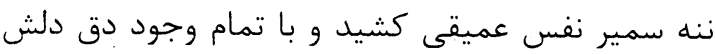

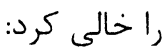
ـ يكدفعه ديكه كه رويت رامى رديدم. از اتاق بيرون شد و دروازه را قفل كرد. در روى حويلى دردي

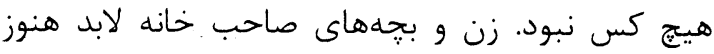

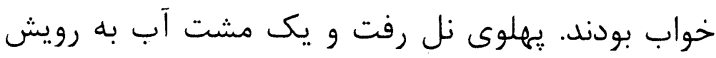

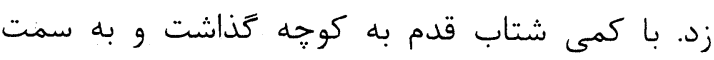
راست روان شد. عكس را در كيسهى مانتويش ماند كه

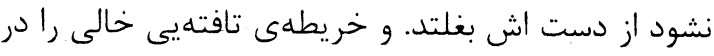

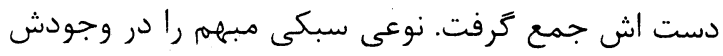

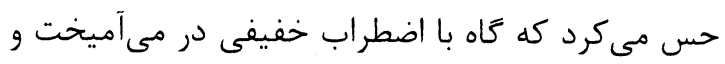

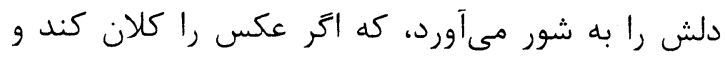




\section{كنوانسيوز حلاقةق طّل}

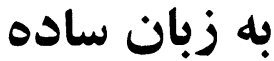

و مليت و مسوليت والدين در تفهيم اين موضوع نيز توسط كنوانسيون تاكيد كرديده است ماده 1 - ماشتن هويت:

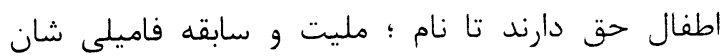
برايشان اعاده كردد.

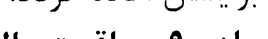

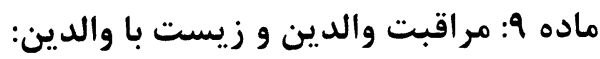

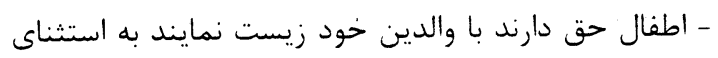

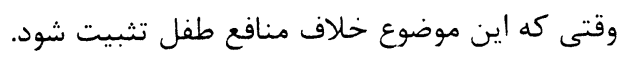

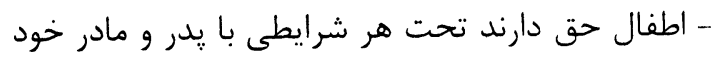
ارتباط برقرار نمايند.

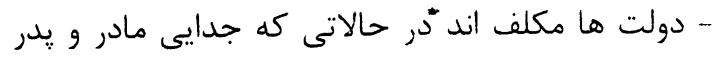

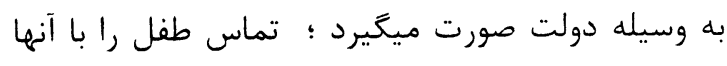

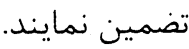
ماده • ا - - ادغام مجدد با واند الدين:

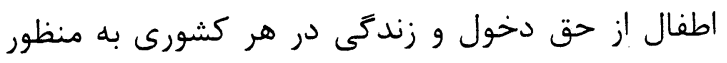

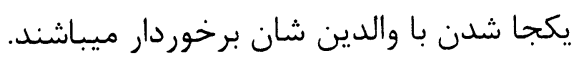

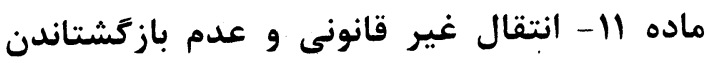
اطفال: دولت ها بايد از انتقال غير قانونى اطفال و عدم بركَت النقال

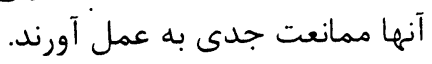
ماده rآ- آزادى اظهار جمار عقيده:

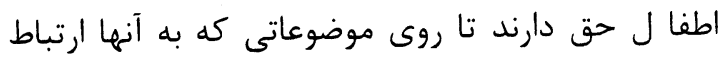

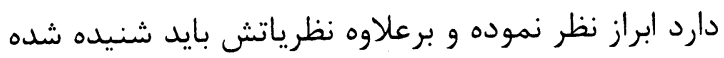

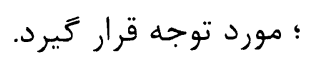

ماده با - آزادى دستر

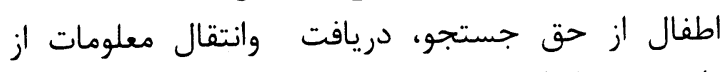
طريق وسايل ارتباط جمعى برخوردار ميباشند. ديافت وانتفال معلوم.
ماده اول: تعريف طفل

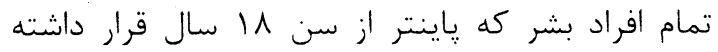

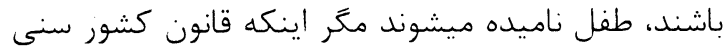

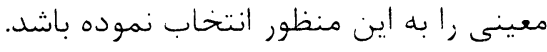

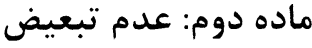
حقوق مندرج كنوانسيون به تمام اطفال بدون تبعن تبعيض قابل تطبيق است. ماده سوم : منافع علياى طفل بر اساس اين كنوانسيون دولت : منافع عادياي طفل مكلف اند تا منافع

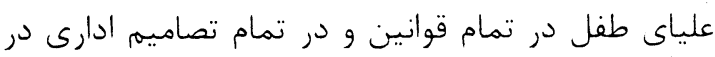

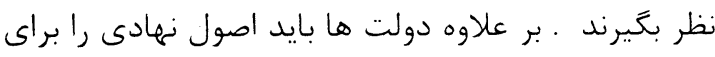

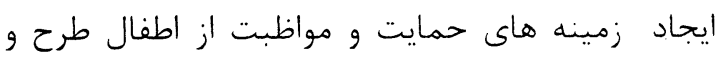

$$
\text { تطبيق نمايند. }
$$

ماده جهارم - تطبيق حقوق طفل:

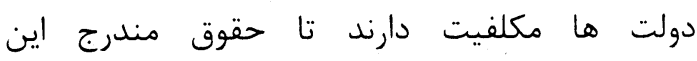

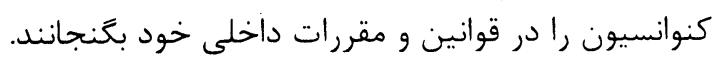

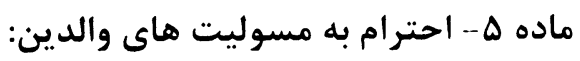

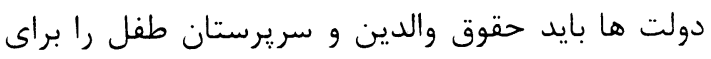

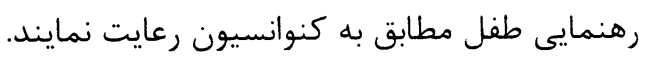
ماده 9- حق حيات و انكشاف:

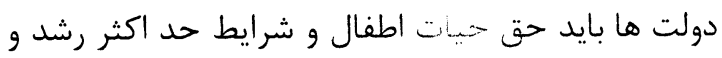

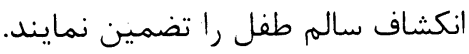

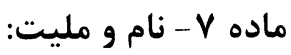
اطفال بايد از حق دام و مليت: باشتن نام مناسب و مليت معين

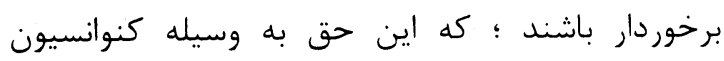
حقوق طفل تضمين شده است. بر علاوه حق دانستن بام 
دولت ها بايد همكارى و كمك لازم را براى حمايت از

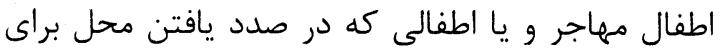

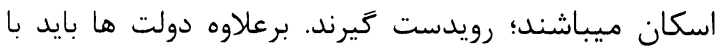

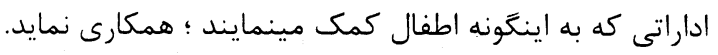
ماده rr - اطفال معيوب: حق اطفال معيوب به مواظبت خاص به به منظور معنور تامين

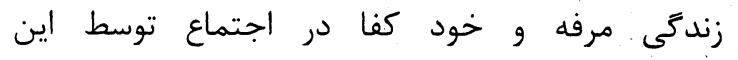

$$
\begin{aligned}
& \text { كنوانسيون تثبيت شده است. }
\end{aligned}
$$

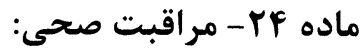

دولت ها مكلف اند تا حق دسترسى به صحت صحت را رابراى

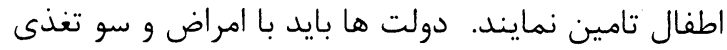

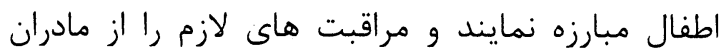

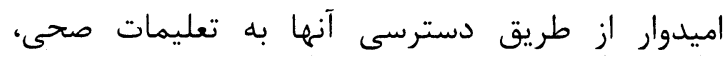

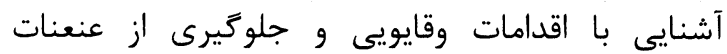
نايسند ؛ به عمل آورند.

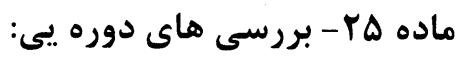

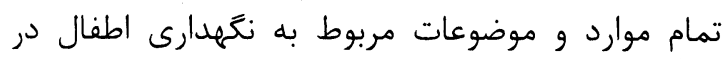

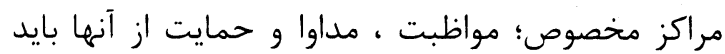

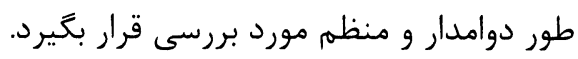

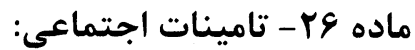

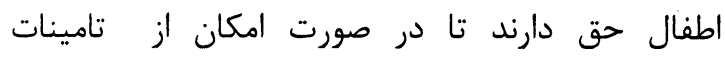

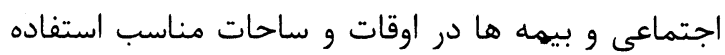

ماده YV - استندرد زند

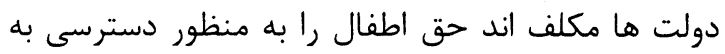

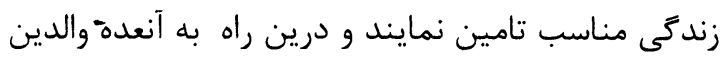

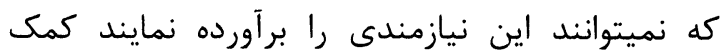
نمايد.

\section{ماده PA ت تعليم و تربيه:} دولت ها مكلف اند تا تعليمات ابتدايى رايگان و و اجبارى ترى

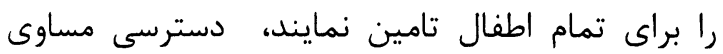
تمام اطفال را به تعليمات متوسطه و عالى تضمين نموده

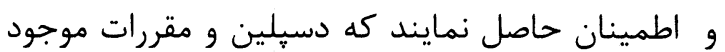
در مكاتب به حقوق بشرى اطفال لطمه وارد نميكند. ماده وץ - اهداف تعليم و تربيه:

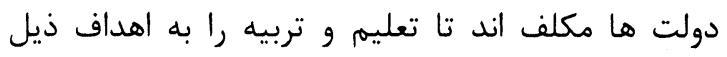
تنظيم نمايند: - رشد مستقيم شخصيت و استعداد طفل نمل
ماده If - آزادى عقيده و مذهب:

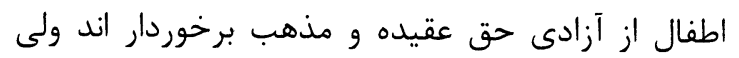

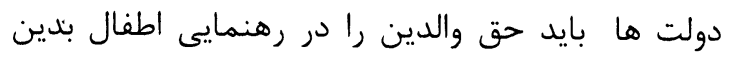
منظور به طور جدى رعايت نمايند.

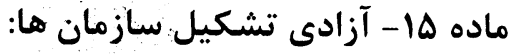

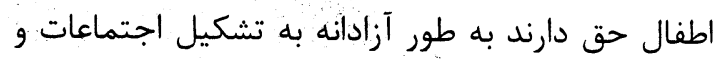
سازمان ها بيردازند.

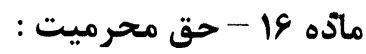
اطفال حق دارند تا در مقابل هرنوع مداخده ميده غير قانونى

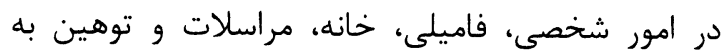
شخصيت اش مورد حمايت قرار گيرند. ماده IV - مطبوعات و معلومات:

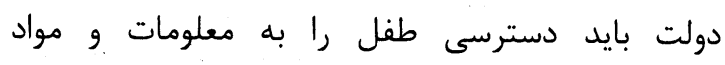
معلوماتى از منابع ملى وبين المللى تضمين نمايد.

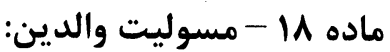

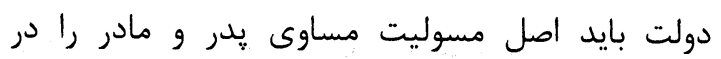

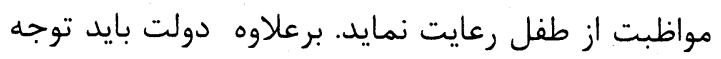

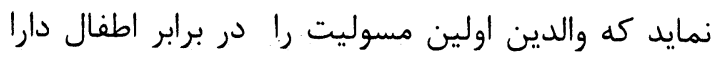
ميباشند. و بلاخره دولت ها بايد والدين را در اجراى الدين مسوليت شان كمك نمايند و اقدامات لازم را جهت كمك به والدين كه اشتغال بيرونى دارند فراهم نمايند.

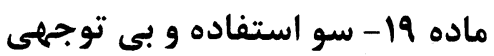

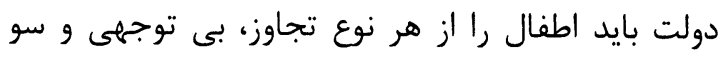

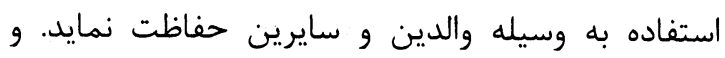

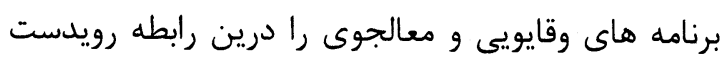
بخيرد. ماده •ץ - اطفال بدون فاميل:

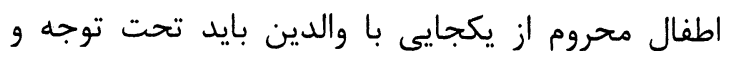
مراقبت خاص دولت قرار داشته باشند. دولت بايد به اين

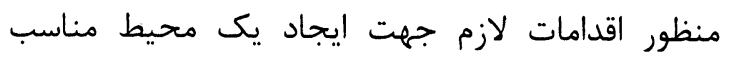
ديخر براى طفل مهيا نمايد ؛ كه اين اقدامات ميتواند

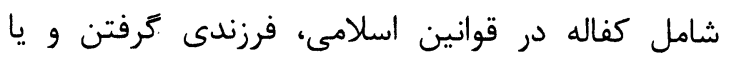
نغهدارى در مراكز يرورش باشد.

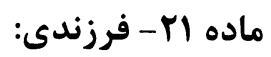
دولت ها ( در جاهاى كه فرزندى گرفتن رايج است) بايد يروسه فرزندى گرفتن را از نظر قانونى اصلاح نمايد. ماده rr - اطفال مهاجر: 
تخطى كه از فرد يايانتر از سن 11 رخ ميدهد؛ مواظبت نمايند. - ( تخطى حقوق اطفال محروم از آزادى براساس موازين انسانى

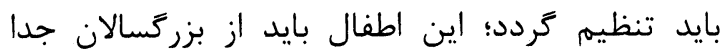

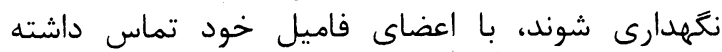

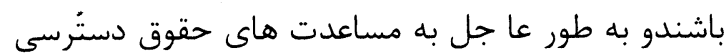

داشته باشند.

ماده ^^- داشتن تفوق در استفاده از استندرد

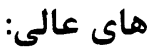
دولت ها بايد موازين بين المللى را در در رابطه به اطفال

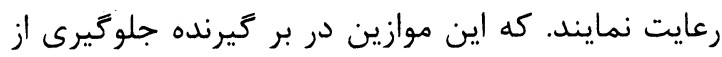

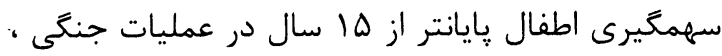

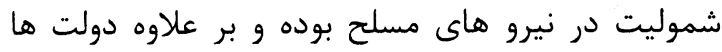

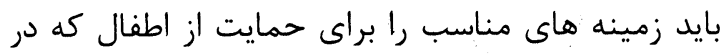

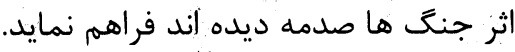

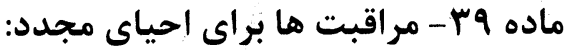

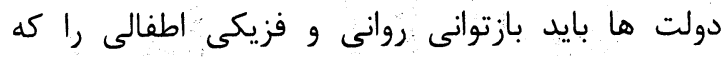

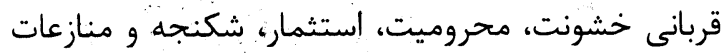

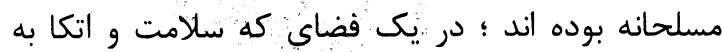

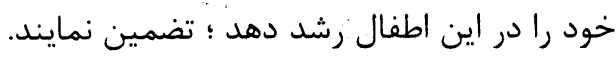

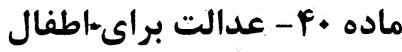
با اطفال در تخلف با قوانين بايد با برخورد انسانى اقدام

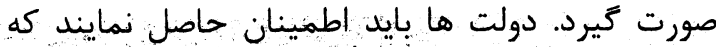

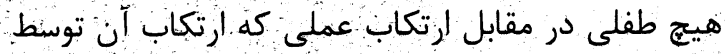
قوانين در وقت ارتكاب جرم شناخته نشده باشد مورد

$$
\text { تعقيب قرار نميخيرد. }
$$

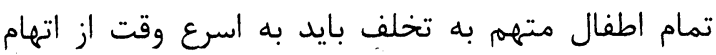

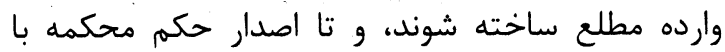
صلاحيت بيخناه دانسته شوند.

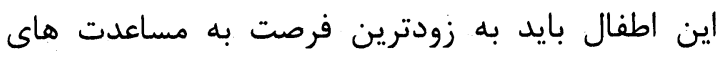

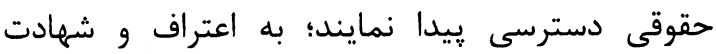

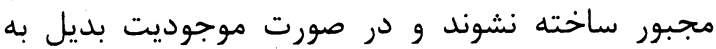

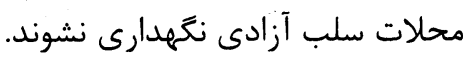

ماده مجلات

اصول مندرج در ين كنوانسيون حقوق و استندرد هاى

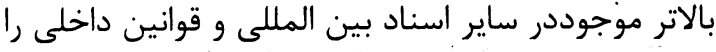
تحت الشعاع قرار نميدهد.
- آماده ساختن طفل براى زندگى مسوولانه در اجتماع - - رشد درجه احترام به والدين

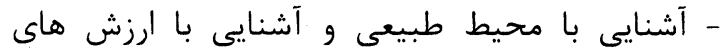

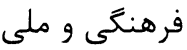

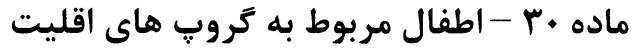

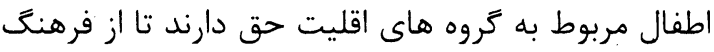

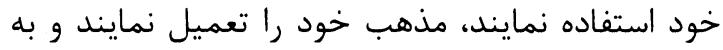
زبان خود صحبت نمايند. ماده آب - تفريح و استراحت نمايند

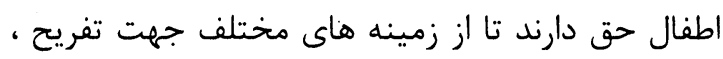

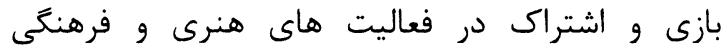

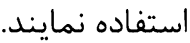

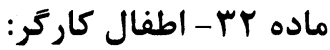
اطفال بايد در برابر بهره بردارى اقتصادى و و شموليت دري دري

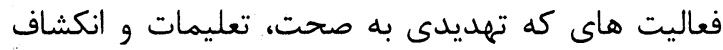

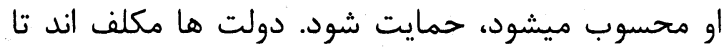

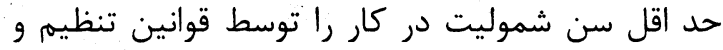

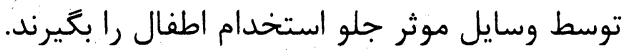

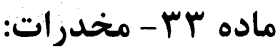
دولت ها بايد اطفال را در مقابل استفاد إناد ازمواد مخدر

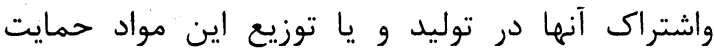

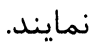

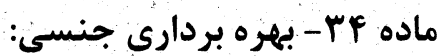
دولت بايد اطفال را در برابر بهره بردئ بردارى و و خشونت

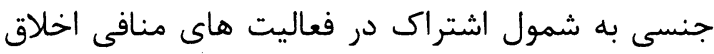

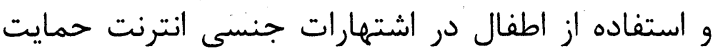

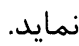

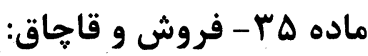
دولت ها بايد از اختطاف، فروش فاقوش و قاجاق اطفال جلو ميرى نمايند. ماده צr- ساير انواع بهره نماند بردارى:

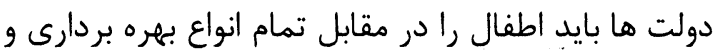
استثمار حمايت نمايند. ماده rV- شكنجه ؛ مجازات سنماتد سنين و سلب آزادى: - (اده: دولت ها بايد اطفال را از شكنجه و ساير انواع خشونت و ادئ

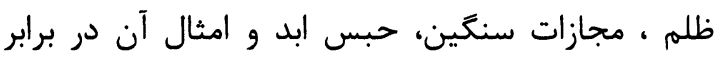


عملى نمـودن تعهـدات افغانسستان بـه حيـث عـضوى از جامعه ملل در جهت حمايت از اطفال، درنكى نماييم. بخش حمايت از حقوق اطفال از آوان آغساز برنامسه هـاى خويش معتقد به اين اصل بوده و است كه إيجـاد زمينــه هاى حمايتى براى حقوق اطفال به تنهايى و تنها و تنهـا توسط كميسيون متصور نبوده ؛ بلكـهـ بــرآورده سـاختن اين مامول نيـاز بـه كـار مسشتر ك و هماهنـعَ بـا سـاير نهادهايى دارد كه در زمينه مشغول فعاليت اند؛ بنابر اين
بخش حمايت از اطفال بسه حيـث يكـى از بخـش هـاى عمده كارى كميسيون مستقل حقـوق بـشر افغانستان

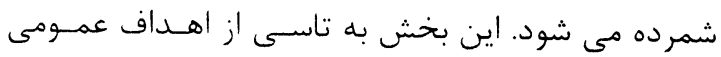
تعيين شده براى دفاع از حقوق بسشر در افغانستان روى حمايت، گسترش و نظارت از حقوق اطفال فعاليت هـاى خود را به ييش مى برد كه براى رسيدن به اين اهداف از وسبائل و طرق مختلفى از قبيل بلند بردن آتاهى مردم و ارتقاء سطح احترام مردم به حقوق طفل، نظارت مستقيم

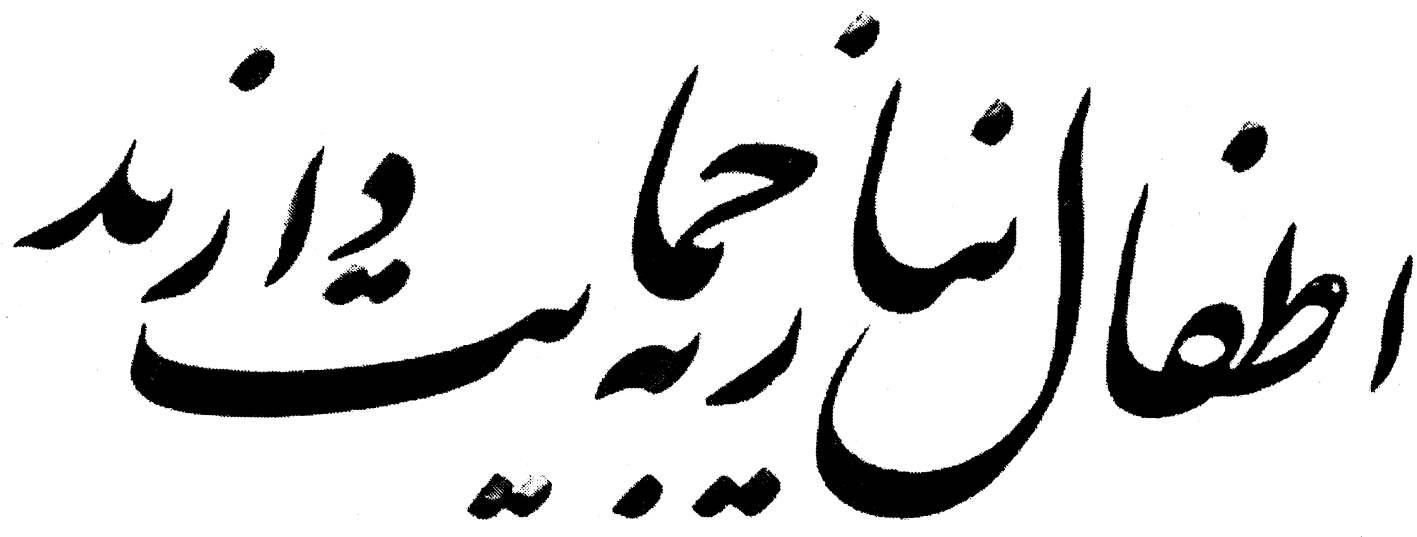

\section{نكرشى بر فعاليت هاى بخش حمايت از حقوق اطفال در كميسيون مستقل حقوق بشر افغانستان}

از عمده ترين فعاليت هاى كميسيون ايجاد همـاهنگى و همكارى بين نهاد و ادارات مختلف دولتىى و غيردولتىى بود كه در راستاى حقوق اطفال كار مى كنند، بـه كونسه مثال مى توان از هماهنغى كارى ايجـاد شـده بـا وزارت محترم كار و امـور اجتمـاعى، مؤسـسات حمايسه اطفـال سويدن، امريكا، جايان و انگًلستان، صندوق بـين المللـى حمايت از اطفال (يونيسيف)، آشـيانه، مركـز حمايست از اطفال ناشنوا و امثال آن يادآور گرديد. اين ادارات از آغاز

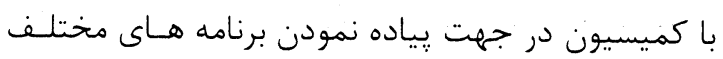

از وضعيت اطفال در محلات و تحست شـرايط مختلـف و ايجاد زمينه بــراى حمايـت از اطفـال از طريـق اشـاعه و

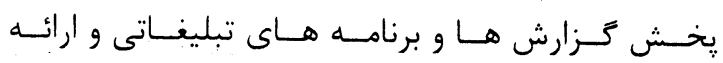

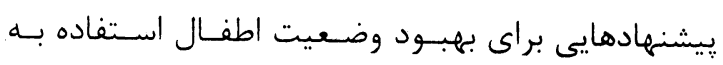

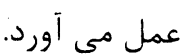
در آستانه تجليل از • ب نوامبر روز بين المللى اطفال بـهـ

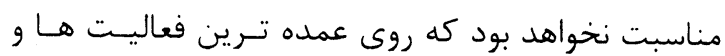
دسـت آورد هــاى بخــش حمايــت از حقــوق اطفــال كميسيون مسـتقل حقـوق بـشر افغانستان در راسـتاى 
ديخًر از اين نهاد كه جمعا حدود ها عضو مى باشـد بـه حيث اعضاى دائمى اين كميته انتخاب كر ديدند. به همين ترتيب از طريق برنامه هاى كميتـه مبـارزه بـاــا قاجاق اطفال كميسيون مستقل حقـوق بـشر افغانستـان سـهم فعـال و برازنـده در بلنــد بـــدن أخـاهى مـردم از خطرات ناشى از قاجاق و اختطاف اطفال، راه ها و شـيوه هاى ييشخيرى از اين حوادث و به همـبن ترتيـب بلنـد بردن سطح آَّاهى مقامات امنيتى و به خصوص يـوليس از نحوه ارتكاب اين عمل و عواقب آن داشـته اسـت. بـر علاوه كميسيون براى تقويت و كسترش تعقيب عـدلى و قـانونى ايـن قـضايا نيزاقــاماتى را انجــام داده اسـت تـا يوليس و ارعان هاى عدلى و قضايى را در جهت اولويست بخشيدن مبارزه و ييخيرى اين قضايا كمك نمايد. برعلاوه جهت حمايت از اطفالى كه قربانى حوادث قاجاق گرديده اند و براى يكجاسازى آنها با خانواده هايشان بسه. طور مصون ؛ كميسيون مستقل حقوق بشر افغانستان بـا همكارى با وزارت محترم كار و امور اجتماعى و همكارى يونيـسـف بـهـ تعـداد · ا تـن نـاظر را جهـت انتقــال و يكجاسازى اطفال كه بدون والدين از كشور هاى مختلف به وطن بازگشت مى نمايند، موظف سـاخته اسـت. ايسن ناظران ضمن تسليمى اطفال به فاميـل هايسشان از ورود

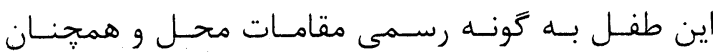
شوراى محل را در جريان قرار مى دهند تـا در آينـده از اين اطفال حمايت لازم به عمل آيد. ب ـ كمك و حمايت به اطفالى كه در تخلف با قوانين قرار دارند و يا به شكلى از اشـكال مرتكـب اعمـالى مـى كردند كه عمل غيرقانونى را انجام مى دهند؛ يكى ديخــر از ساحات عمـده كـارى كميسبيون بـه شـمار مسى رود. همكاران بخـش حمايـت از اطفــال كميـسيون مسـتقل
در راستاى حمايت از اطفال افغان همكارى هاى فـراوان به خهز داده اند. الف -- يكى از دست آورد هاى عمده كارى كميسيون در جهت جلب توجه براى حمايت از اطفـال همانـا فعاليـت هاى متعدد و هماهنغ كميسيون در رابطه به حمايت از اطفال از خطر قاجاق شدن آنها بود. كميسسيون مسستقل

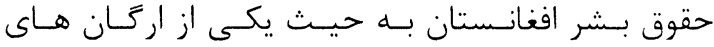
مسؤول و مصمهم در راسـتاى حمايست از اطفـال، اولـين اركانى بود كه تشويش خود را در رابطه به لست رو بـه ازدياد قضاياى قإجاق و در مجموع مفقودى اطفــال ابــراز داشت و به همين سلـسله جهــت جلـب توجـهـ مقامـات امنيتى كشور به حساسيت موضوع، مجلس بزرگى را بـهـ اشتراك مقامات عاليرتبه وزارت امور داخله افغانسـتان از مركز و ولايات كشور بـه شـمول قومانـدان هـاى امنيـهـ ولايات، قومندان هاى يوليس سرحدى، مسؤولين حـوزه

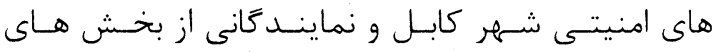
جنايى وزارت داخله، ثارنوالى، محاكم، وزارت امور زنسان، نمايندگانى از نهادهاى مدافع حقوق طفل در شهر كابـل داير نمـود كـه دسـتاورد هــاى جـشمعيرى را در قبـال داشت؛ از جمله مى توان از صدور فرمـان مقـام رياسـت دولت (به كوشش وزارت محترم كار و امور اجتماعى) در جهت ايجاد كميته با صلاحيت تحت نام كميتـه مبـارزه با قاجاق اطفال به اشـتراك نماينـدمًان بـا صـلاحيت از وزرات هاى محترم عدليه، داخله، كار و امـور اجتمـاعى، حج و اوقاف، امور زنان و برعلاوه اداراتى مانند كميسيون مستقل حقوق بشر افغانستان، نمايندگًانى از ادارات ملـل متحد مثل يوناما، يونيسف، كميسارى عالى ملـل متحـد در امــور يناهنــدَّان و بــــعلاوه مؤسـسـات غيردولتــى علاقمند به موضوع جون اتحاديه حمايت از اطفالو بعضى 
צ- برعلاوه كميسيون مستقل حقوق بشر افغانستان قادر گرديده كه در ولاياتى مثل بلخ و گرديز زمينسه رابــراى ايجاد همجو مراكزى به منظـور جـــا سباختن اطفــال از بزرگسالان فراهم نمايد و در ساير ولايات قادر زرديذنـــ كه حداقل با كمك مسؤولين يوليس و ثارنوالى امكانـات تهيه اتـاق جداگحانـه را بـراى ايسن دســه اطفــال فـراهم نمايند. اما بايد توجه داشت كه هنوز هم مسشكلاتى كـه اين دسته اطفال به آن مواجه اند، اندك نبوده به سعى و تلاش جدى و بيگير نياز دارد. ج- به همين ترتيب به منظور كمك بـه اطفـال كـارگر، كميسيون يك سلسله اقداماتى را رويدست گرفته اسـت؛ از جمله مى توان به اشتراك فعال كميسيسيون در شـبكه حمايت از اطفال كارگر اشاره نمود كه از اين طريـق بـهـ مشكلات اطفال كارگر در سـاحات مختلـف توجــه شـده است به همين ترتيـب بـه مناسـبت روز جهـانى اطفـال كارگر برنامه مفهل تلويزيونى به راه انداخته شد كه طى آن جند تن از اطفال كارگر با مسوولين يوليس، ترافيـى و وزارت محترم كار و امور اجتماعى به بحسث ٍرداختنـد كه در نتيجه به بعضى از مشكلات ايسن تـروه از اطفـال مانند عدم دسترسى شـان بـه سـرويس هـاى شهرى و امثال آن رسيدگى گرديد. به همين منــوال همكــاران بخــش حمايـت از اطفــال در كابل و ساير ولايات كشور نظارت دوامدار از وركشاٍ ها و محلات كار اطفال كارگر به عمل مى آورند تا باشــد از طريق تفاهم با صاحبان كارخانه ها از شـدت كـار بـالاى اطفال كاسته شود. برعلاوه جهت عطف توجه عامه مردم به مشكل اطفال كارگر، نشراتى از قبيـل يوسـتر و اوراق تبليغاتى تهيه، و به دسترس مردم قرار داده شده است.
حقوق بشر افغانستان با همكارى بخش بررسى از تخطى هاى اين كميـسيون اقـدامات مـوثر و جــشمخيرى را در رابطه به حمايت از اين گروه از اطفال به تاسى از اسـناد قبول شده بين المللى انجام داده اند كـهـ بـه شـمارى از

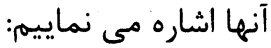
ا- از آغاز كار كميسيون تا به حال بيش از • •ه طفل كه به شكل غير قانونى تحت بازداشت قرار داشته اند، از حبس رها ساخته شده اند. Y- ممنوعيت مجـازات و شـكنجه جسسمى اطفـال در معرض تخلف با قوانين به يِيمانه وسيع تبليغ گرديـده و در نتيجه كراف اين نــوع شـكنجه هـا تـا انـدازه اى در بسيارى از نقاط كشور تقليل يافته است. r- يرسونل و كارمندان يوليس، ثـارنوالى و محساكم در رابطه به نحوه ى بر خـورد شـان بـا اطفـال متخلـف در وركشاب هاى مختلف در سرتاسر كشور تنظيم گرديـده كه يروسه تدوير اين وركشاب ها به شكل گسترده تر آن

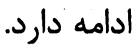

F - به منظور مطالعه عوامل تخطى اطفـال از قـوانين و نحوه برخورد مقامات عـدلى و قـضايى كـشور در زمينسه گزارش تحقيقاتى انتشار يافته كه بـه دسـترس عـده ى زيادى قرار گرفتـهـ اسـت (علاقمنــدان مسى توانتـد ايسن كزارش رالز كتابخانه كميسسيون مسستقل حقـوق بـشر افغانسستان در كابـل و از دفـاتر ســاحوى كميسسيون در ولايات به دست آورند). ه- از مراكز اصـلاح و تربيـت اطفـال در كابـل و سـاير ولاياتى كه اين ساختار موجـود اسـت بـه طـور دوامـدار مراقبت صورت كرفته و براى بهبود وضعيت با مسسوولين تماس هاى مستقيم ايجاد كرديده استت. 
خواهند داد كه بعد از ارزيابى موثريت آن، اين برنامه بـه گروه هاى وسيع ترى از اطفال گَترش خواهد يافت. بلاخره كميسيون مستقل حقـوق بـشر افغانستان بـه بهانه تجليل از روز هاى مختلف ملسى و بـين المللى در رابطه بـه اطفــال، نسشر برنامـهـ هــاى ويسرزه تلويزيـونى و راديويى، انتشار يوستر ها و اوراق تبليغـاتى، اشـتراك در مجالس و محافل در سطح ملى - منطقوى و بين المللى كوشيده است تا ضرورت مبرم حمايت از اطفال افغـان را همواره به حيث يك نياز اساسى و مبرم مورد توجه عامه

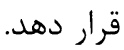

كميسيون مستقل حقـوق بسشر افغانسستان ضـمن ابـراز

تبريكات صميمانه به مناسبت روز جهـانى اطفـال اميـد دارد تا اطفال افغان نيز مانـــد سـاير اطفــال در سرتاسـر دنيا اين دوره حساس زندگى را به شكل موثر و مناسـب آن پشت سر بحذارند.
د. اطفال داراى ناتوانى يا اطفال معيوب گروه ديخــى از

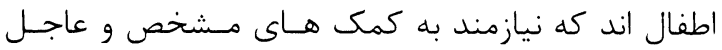
ميباشند. براى مطرح شده مشكلات اين گروه از اطفـال، كميسيون مستقل حقوق بشر افغانستستان سـال كذشـــه

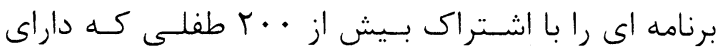

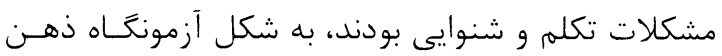
ترتيب نمود. يخش اين برنامه از طريق تلويزيـون باعثث كرديد كه حداقل برنامه خبرى مشخص براى افراد داراى مشكلات شنوايى به شكل اشاريى ترتيـب شـود كـه هـر

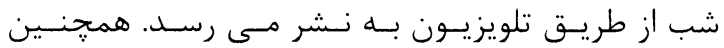
همكارى ميان كميسيون و بنياد ايفا جريان دارد.

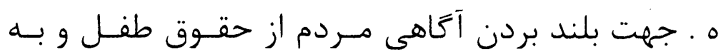

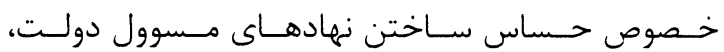
يوليس، قضات، معلمين، دكتوران و ساير اقـشار جامعسه، كميسيون دست بـه جـاب و نسشر كتـابى تحست عنـوان آموزش حقوق طفل زد كه امروز از اين كتــاب بــه كونسه گسترده به حيث مواد درسى در موسـسات تحصيلات عالى در اكثر ولايات كشور استفاده مى گردد. برعلاوه وركشاب ها و برنامه هاى متعدد آَاهى دهى در رابطه به حقوق طفل در مركز و ولايات كشور تدير يافته است. به همين ترتيب شامل سـاختن اطفـال در برنامـهـ هاى آَّاهى يكى از فعاليت هاى عمده كارى كميسيونيون

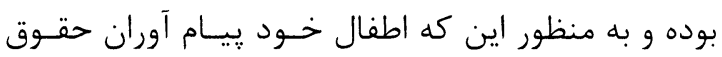
خويش به سايرين باشند؛ كميسيون مستقل حقوق بسر افغانستان با همكارى مالى موسسه حمايه اطفال سويدن به تعداد •^ طفل را به حيث مربيان رضاكار تربيه نموده

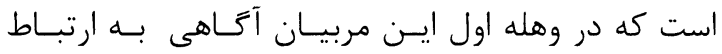
حقوق طفل را كه برگرفته از كنوانسيون حقوق طفل مى مى

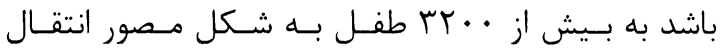




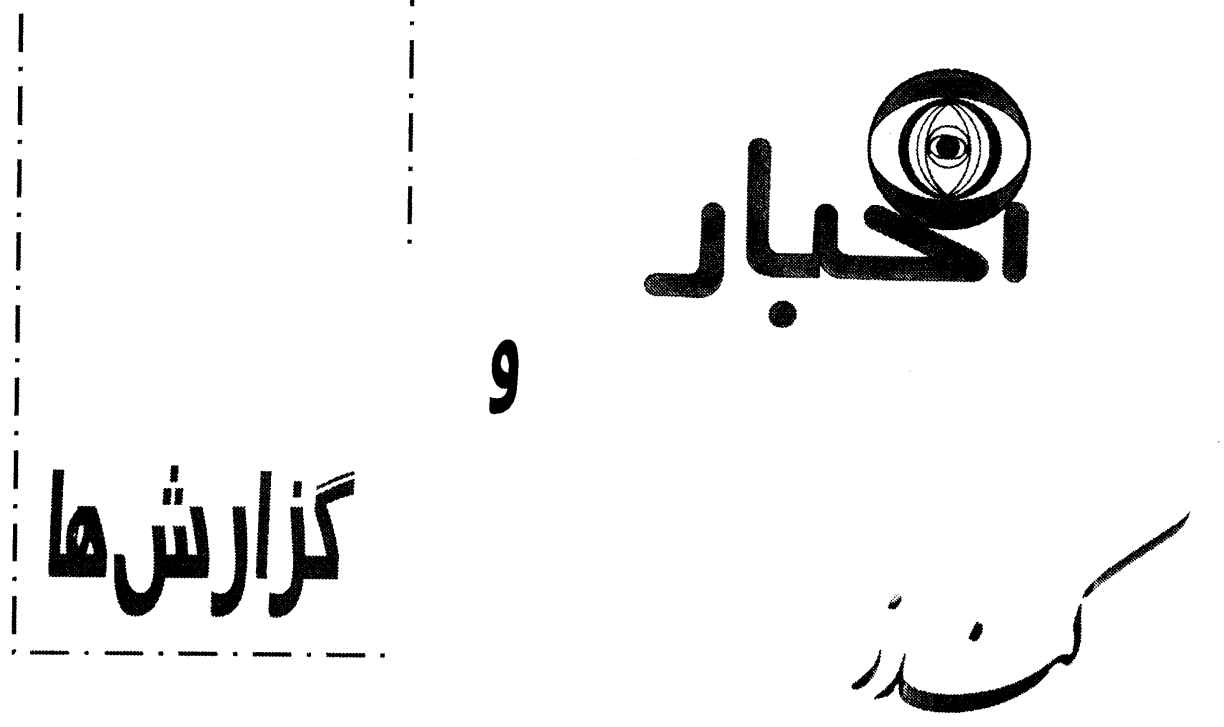

\section{تلاش براى تأمين حقوق بشر}

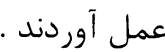
درآغاز، اين هيأت با والى ولايت بغلان ديدن نموده مشكلات مهاجرين عودت كننده و يروسه نظارت از حقوق سياسى و مدنى شهروندان را مطرح كرده و

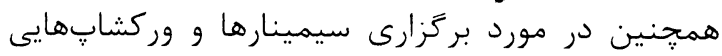
در ولسوالى هاى دوشى و خنجان كَفتخو نمودند. محترم والى ولايت بغلان ضمن صحبت هاى خويش وعده هرنوع همكارى را بهخاطر تحقق اهداف نيك كميسيون، حل مشكلات مهاجرين و عرايض وارده به دفتر ساحوى هرى

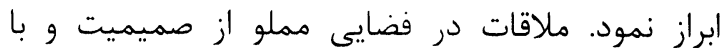
آرزوى حاكميت قانون و صلح سراسرى به يايان رسيد. همجنان مسؤولين دفتر ساحوى بعد از ظهر همان روز با محترم رئيس اطلاعات و فرهنگ ولايت بغلان ديدن نموده و روى برنامه ها و يلان نشراتى بخش مطبوعات دفتر ساحوى صحبت نمودند، إيشان نيز وعده همكارى خويش را جهت تحقق اهداف نشراتى بخش مطبوعات دفتر ساحوى ابراز نمودند. درختم ديدار يك تعداد مجلات حقوق بشر براى كارمندان راديو تلويزيون، جريده اتحاد و آزانس باختر توزيع گرديد.

\section{ديدار از شهر يلخمرى و ولسوالى هاى}

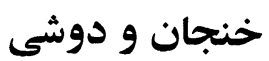

هيـأتى از جانـب دفتــر سـاحوى كميـسيون

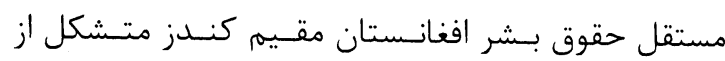

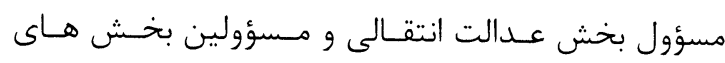

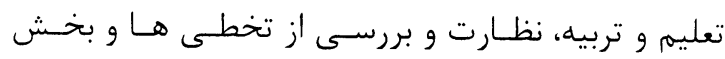

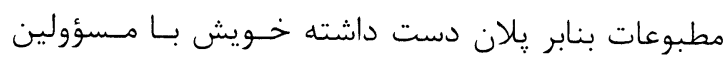

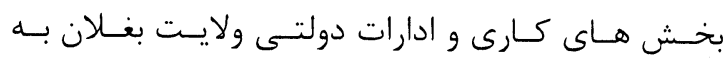
روزهاى نهم، دهم و يازدهم سنبله سـال روان ديـدار بـــ

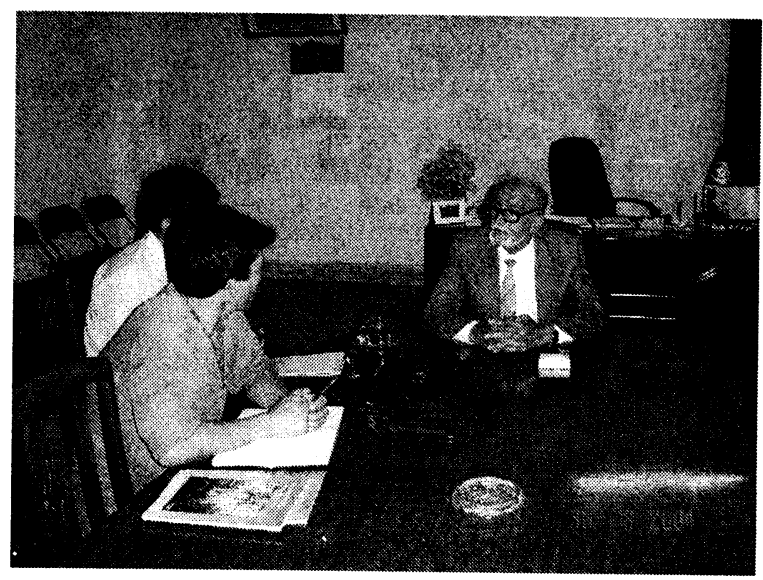

2
9
1
1
3
3
2
2
2
3
3
3
2
3
3
2

77 
ساحوى تدوير يافته بود، توضيح اعلاميه هـاى جهـانى و اسلامى حقوق بـشر يروسـه انتخابـات وحقـوق سياسـى مدنى اتباع كشور بود. در آغاز محترم يِيوند عضو نظارت و بررسى از حقـوق مـدنى و سياسـى دررابطـهـه بـهـ مــواد اعلاميـه جهـانى و اسلامى حقـوق بسشر، سـهم زنـان در "يروسـه انتخابـات رياست جمهورى و يارلمان وشـوراهاى محلى و يروسـه برززارى انتخابـات و جريسان مبـارزات انتخابـاتى وسـهم مردان و زنان در انتخاب رئيس جمهور آينده افغانستان مفصلاً توضيخات ارائه دادند. يسس از آن مسـؤول بخـش رك عدالت انتقالى زييرامون مفاهيم عـدالت انتقـالى و بخـش هاى كارى شان صـحبت كردنـد. در اخيــــ نيـز محتـرم

\section{بازديد از ولسوالى خان آباد}

همجنين سيمينارى تحت عنوان (انتخابـات و

حقوق بشر) به ابتكار بخش تعليمى و تربيه دفتـر سـاحوى كميـسيون مسـستقل حقــوق بـشر افغانـستان در ليـسه ابومسلم خراسـانى ولـسوالى خنجسـان بـه اشـتراك عـده زيادى از اسـتادان و شـاگردان آن ليسـه دايسر گرديـد و دررابطه به اهداف و بخش هاى كارى كميسيون، يروسـه انتخابات و حقوق سياسى ـ مدنى اتباع كـشور معلومـات مفصل توسط معاون بخش تعليم وتربيه و مسؤول بخش عدالت انتقالى ارائه گرديـد. قابـل يادآوريسـت سـيمينار ديخرى تحت عنوان(معرفت بـا حقـوق سياسـى مـدنى و انتخابات) در ليـسه انـاث معـدن ذغـال سـنَّ رياسـت معسـارف ولايست بغـلان بـهـ اشـتراك بيـشتر از هاتـن از اســادان و شــاكردان آن ليــسه تــدوير يافــت و روى موضوعات حقوق بشرى، كنوانسيون رفع كليه تبعيـضات عليه زنان، آزادى بيان، حـق تاسـيس انجمـن هـا، حـق آزادى اجتماعات، تاريخجه عدالت انتقالى و هدف ايجـاد بخش عدالت انتقـالى توضـيحات مفـصلى ارائـه شـد. در پِايـان نيـز تعـدادى از مجــلات و بروشـورها مربوط به حقوق بشر براى حاضـرين توزيـع كرديد. (- n هيأتى از طرف كميسيون مستقل حقوق بــشر افغانسـستان بـــهـ روز يكــشنبه مــورخ

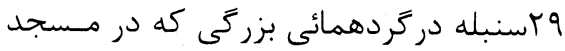
جامع محب الله در شهر خـان آبـاد كـه بـهـ

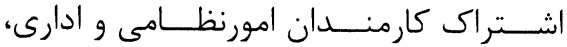
مديران مكاتب، متتنفـذين، شـاگردان وعـده زيادى از اهالى شريف خان آباد داير خرديده

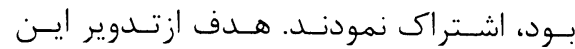
گر دهمـائى كــه بــه ابتكــار مـسؤولين دفتـر 
سياسى مدنى شهروندان در جريان انتخابات صحبت نمودند و هدف از اين ديدار توضيح و تشريح جهار حق و سه ״رنسيب جون: آزادى بيان، آزادى اجتماعات، آزادى ديد

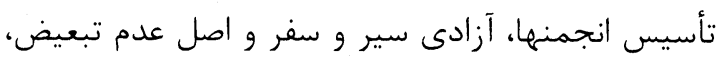

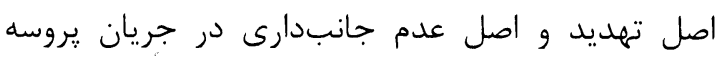

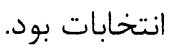

در آغاز برنامه مسؤول بخش تعليم و تربيه در رابطه با

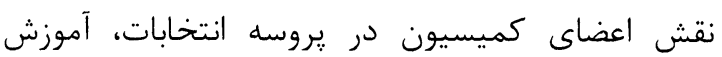

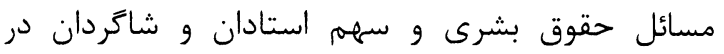

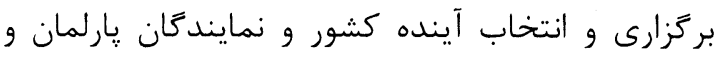

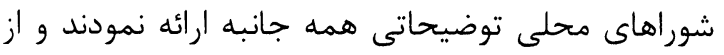
مسؤولين ليسههاى متذكره خواهش نمودند مطابق به دستورالعمل و قانون انتخابات عمل نموده و از اعمال نفوذ بر رأى دهندگان خوددارى به عمل آورده شود؛ زيرا

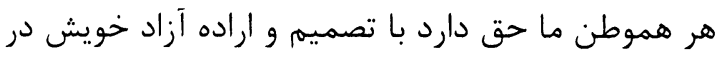
انتخاب زعيم آينده كشور مشاركت ورزد و و زعيم آينده خود را مطابق به خواست خود انتخاب نمايد. همجنين يك تعداد بروشؤرها، مجلات حقوق بشر و يوسترهاى مربوط به انتخابات نصب و توزيع گرديد.

\section{بازديد از ولسوالى على آباد ولايت كندز}

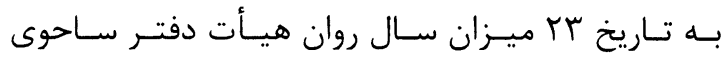
كميسيون در كندز مشتمل بر مسؤولين بخشهاى تعلـيم

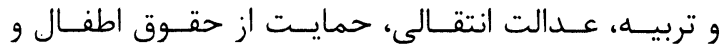

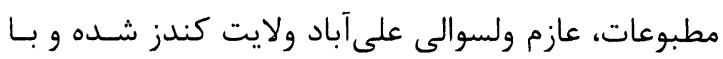
محترم ولسوال، قوماندان امنيه، ثارنوال، مـدير معـارف و

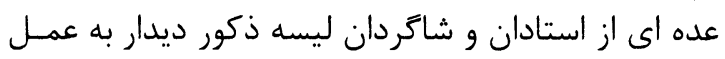

ازحقوق سياسى مدنى و بخش هاى كـارى كميـسيون از دفاتر احزاب سياسى و سازمان هايى كه دفاتر خود را در درى

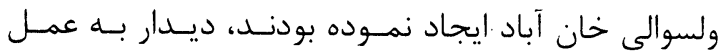

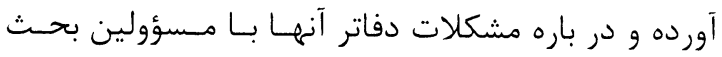

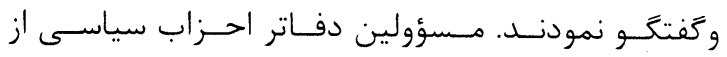

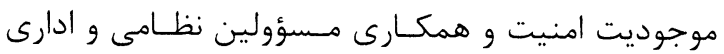

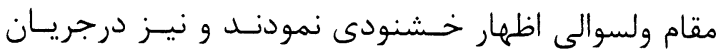
ملاقات ها وكردهمائى كه در ولسوالى خان آبـاد صـورت

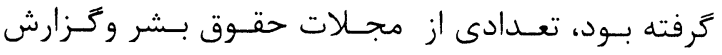

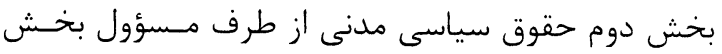
مطبوعات دفتر ساحوى توزيع گرديد.

\section{بازديد از ليسههاى ولايت كندز} هيأتى از طرف دفتر ساحوى كميسيون مستقل حقوق بشر افغانستان در اوايل ميزان سال روان با محترم عبدالباسط معاون ادارى رياست تعليم و تربيه ولايت كندز ديدار به عمل آورده و در ربد رابطه باسبا وظايف

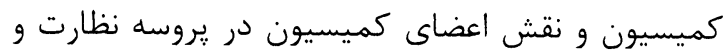
بررسى از حقوق سياسى - مدنى شهروندان در جريان انتخابات و مبارزات انتخاباتى و سهم و نقش استادان و شاگردان در تعيين زعامت كشور و آموزش مسايل حقوق بشرى و بررسى موارد نقض حقوق بشرى در

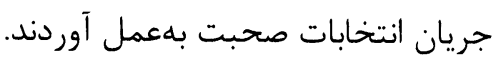

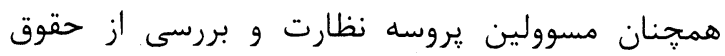

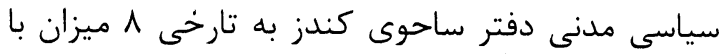

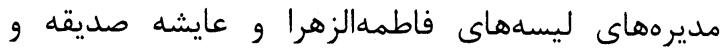
استادان و شاگردان ديدن نموده و روى يروسه حقوق 


\section{حقوق بشر، تعليمات مدنى \\ و يروسه انتخابات}

وركشاٍ دو روزهاى تحت عنوان(رابطه دادن حقوق بشر

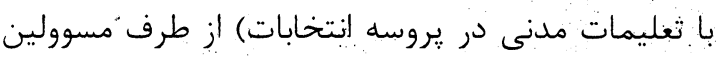

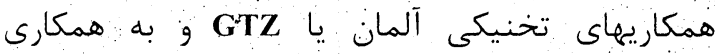

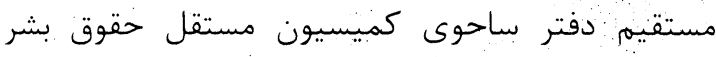

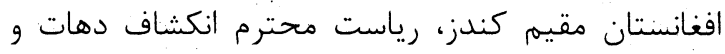

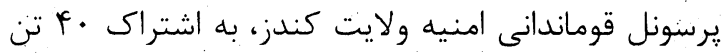

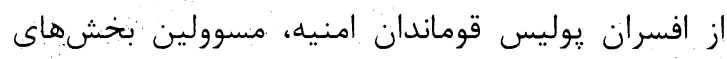
دفتر ساحوى، كارمندان انكشاف دهات و استادان

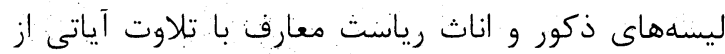
كلام الهى توسط يك تن از شركت كنندَان به كار بـ آغاز

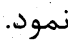

هدف از تدوير اين وركشابٍ رشد مشاركتها براى آوردن صلح و امنيت در زون شمالشرق مىباشد. سخنرانى

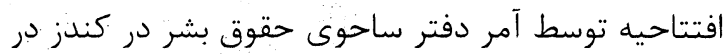
رابطه به وركشاب متتذكره و وظطايف كميسيون مستقل حقوق بشر افغانستان و دفتر سناحوى صورت گرفت و و به ونه

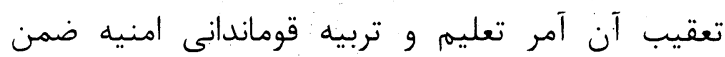

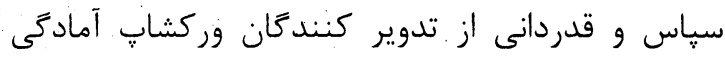
خود را به نمايندگى از يرسونل قوماندانى امنيه در جهت برقرارى صلح و امنيت و اجراى موفقانه يروسه انتخابات

$$
\text { در ولايت كندز ابراز نمود. }
$$

همجنان كار جمعى درباره خانه جديد ما افغانستان، اجرا

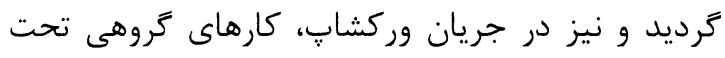

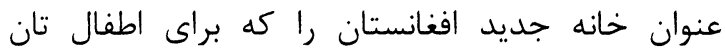

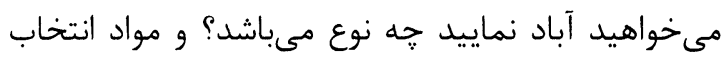

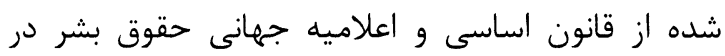

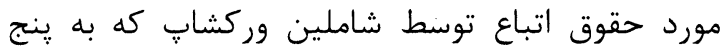

آورده روى اهداف كميسيون، نقـش اعضاى كميـسيون مستقل حقوق بشر در بروسه تطبيـق حقـوق سياسى و

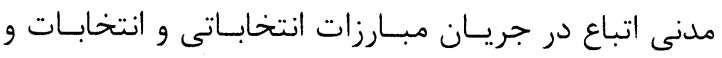
سـهم مـسوولين ادارى و نظــامى ولـسوالى در جريـان برگزارى يروسه انتخابات و دستورالعمل قانون انتخابـات براى كارمندان دولتى و مقامات نظـامى بحـث و كَفتـــــ نمودند. در آغاز، معاون بخش تعليهم و تربيه در زابطه بـه وظــايف

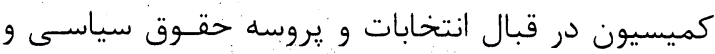
مدنى توضـيحات مفـصل ارائـهـ نمـوده، كفتـــــ (دولـت

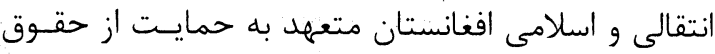

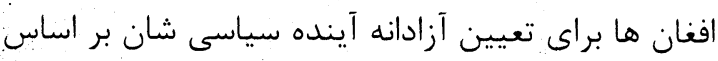

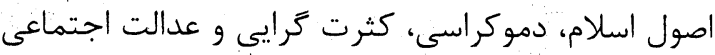

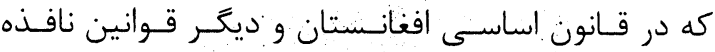
كنجانيده شده است، مى باشد.

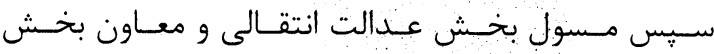

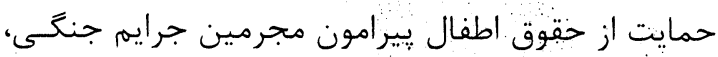

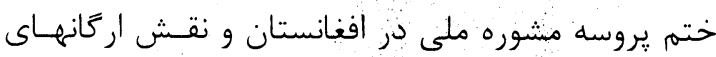

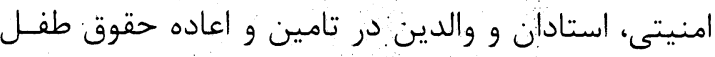

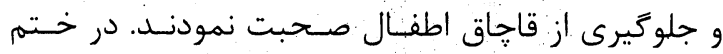

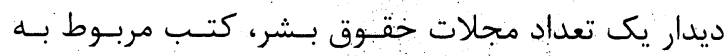
حقوق طفل يوسترهاى مربوط به يروسه انتخابات توزيـع كرديد.

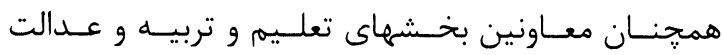

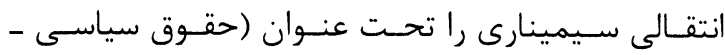
مدنى) به اشتراك عـده كثيـرى از اسـتادان و شـاتردان ليسه شماره يك نسوان رياست معارف ولايت تخار دايـر

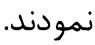


اين دهكده تداعى كنبنده يك سرزمين زلزله زده و ويران شده است كه باشند Fان آن مهاجرين هستند كه سال ها قبل، از بيهم جنَ به اين مخروبه يناه بــرده انـد. در ايسن

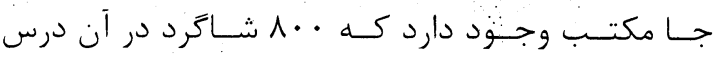
مى خوانبد. شاگردان بأ رنغ زرد، ياهاى برهنه و لباسهاى يينه شده به داخل مكتب رفت و آمد مى كنند كه ديدن اين صحنه ترازيك و درد آور قابل تحمل نبوده، احساس هر انسان با وجدان را نسبت به بى تفاوتى مسؤولين امور تحريك مى كند. در اين منطقه بيشتر از . ז1 خانواده با حالى رقتبار زندگَى مي كنند و در فاصله اى نزديك به شهر كندز، دزمرمائ “سوزان تابستان از نعمت برق محروم اند و هيج نوع سرگرمى جهت تامين زندگى براى جوانان اين منطقه فراهم نيست. آب آشاميدنى، كلينيك صحى و لابراتوارهاى تشخيص ملاريا و آميب كه در مر ميان باشندگًان إين محل سخت بيداد مى كند تا هنوز مسؤولين امور در زمينه تصميمم اتخاذ نكرده اند. اركَانهاى حمايت از حقوق طفل و مادر از وضعيت رقتبار مادران و اطفال اين منطقه آَاهى ندارند؛ به قول (ملاتوره) در برج اسد سال روان دو زن در هنگام وضع حمل فوت كردند. مرگ و مير اطفال از اثر امراض و سو تغذى بلاوقفه ادامه دارد. مردم محل مى گويند: اكثريت قريب به تمام، از دو سال به اين طرف در خانههاى خويش روى زوشت را نديده اند، در مورد مواد سوخت به مشكل مواجه هستند زنها و اطفال كه جهت جمع آورى بتهها و ساقه هاى بازمانده حبوبات به زمينها مى روند از طرف مالكين زمين ممانعت صورت مى گيرد. زنان محل در وقت فصل به جمعاورى حاصلات لوبياى زمينداران مصروف مىشوند كه در بدل جمع آورى مرى كيلو لوبيا مبلغ ^ افغانى مزد مى گيرند. زمينه تشويق براى مهارتهاى دستى زنان فراهم نغرديده و هيج

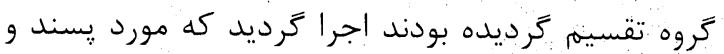
علاقمندى اشتراك كنندَان واقع كرديد:

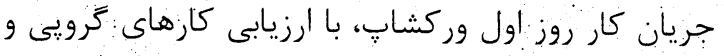
كار جمعى حوالى ساعت f بعد از ظهر در فضبايني منملو از صميميت و به اميد ييروزى انتخابات و و برقارى حاكمّنِت قانون در كشور به يايان رسيد.

\section{آيا باشند Fان باغ شر كت مجرم هستند}

كميسيون مستقل حقوق بشر افغانستان و مسؤولين دفاتر ساحوى آن ييوسته به خاطر روشن ساختن افكار عامه و شناختن عوامل نقض حقوق بشر و جلوگيرى از آن به ولبنوالىها و محلات ولايات سفرهاى كارى انجام مى دهند. همواره فريادها و ضجههاى استخوان سوز شهروندان ما، از نبود عدالت اجتماعى، از حاكميت افراد مسلح غير مسؤول، از خشونت و استبداد بىرحمانه صاحبان زور و زر، از انجام ازدواجهاى اجبارى، از تقصير اركانهاى حراست از قانون، از عدم مسؤوليت مسؤولين اجرائى در تطبيق و رعايت قانون در زوشه و كنار آن طنين انداز است. مسؤولين دفتر ساحوى كميسيون مستقل حقوق بشر مقيم كندز در رفع اين همه موانع و مشكلات با اركانهاى ذيصلاح تفاهم مىكنند و زمينه ساز رفع نقض حقوق شهروندان مىشوند. مسؤولين بخشهاى تعليم و تربيه، عدالت انتقالى و حمايت از حقوق زن دفتر ساحوى از باغ شركت كه در • • r كيلومترى مركز ولايت شهر كندز قرار دارد، ديدار به

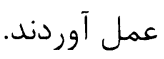

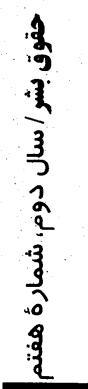

V. 
آن، همجنين در مورد كمك به زنان نيازمند توسط

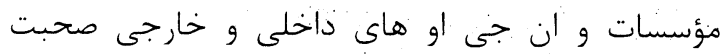

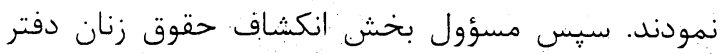

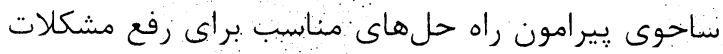

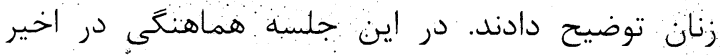
شاملين نكات ذيل رابه تصبويب رسانيدند.

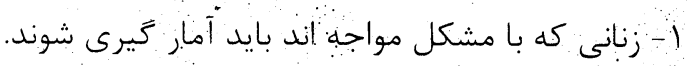

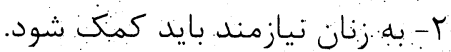

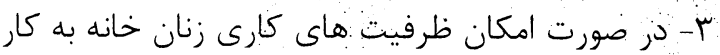

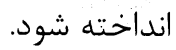

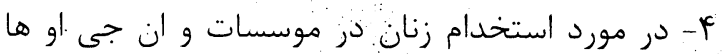
توجه لازم صورت كيرد. ه- براى رشد و انكشاف فكري زنان برنامههاى تبليغى تهيه و تطبيق گردد. اين جلسه با توزيع مجلات حقوق بشر به بايان رسيد.

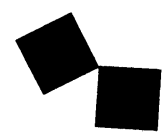

\section{جلو Fيرى از خشونت عليه اطفال}

به ابتكار بخش حمايت از حقوق اطفال دفتر ساحوى

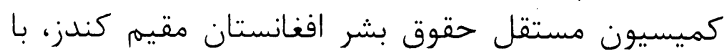
اشتراى عده اى از استادان ليسههاى ذكور و و اناث رياست معارف ولايت كندز در روز V ميزان محفلى تحت

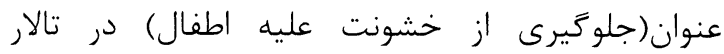
كنفرانسهاى دفتر ساحوى داير گرديد.

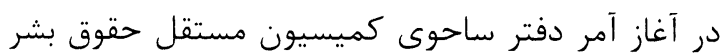

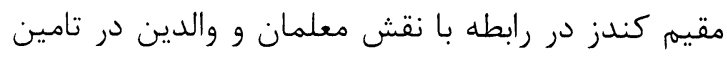
و اعاده حقوق طفل و تجديد تربيت اطفال و ايجاد مراكز

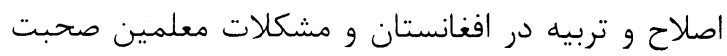
نموده كفتند: الدر جوكات كميسيون مستقل حقوق بشر
اركان مسؤولى تا كنون در زمينه اقدام نورزيده است. اين همه كاستى ها، زمينه ساز نقض حقوق بشر است،

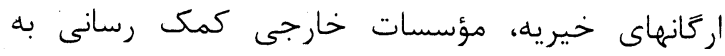

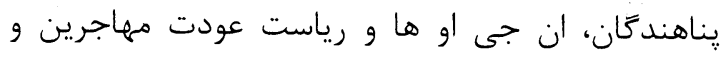

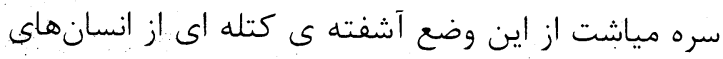

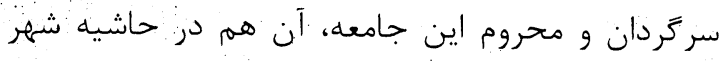

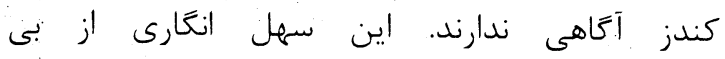

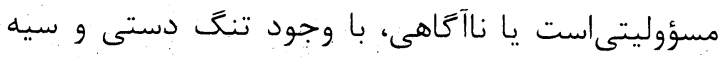
روزى اين.مردم محروم و در تنخُنا قرار كرفته ى ميا،

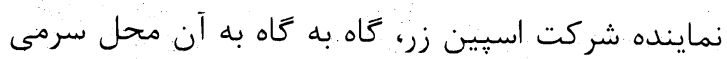

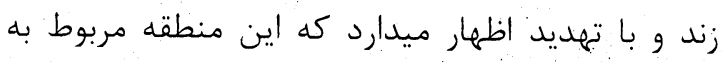
شركت است و بايد تخليه شود. بر اساس قانون اساسى

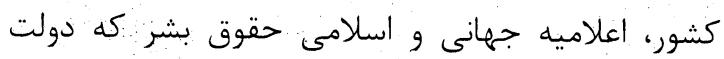

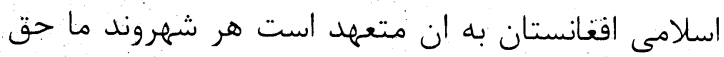

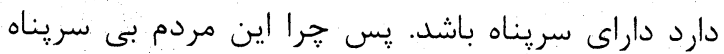

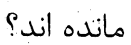

\section{مشكلات خانوادهها و راه حلهاى آن}

از طرف بخش انكشاف حقوق زنان دفتر ساحوى كميسيون مستقل حقوق بشر افغانستان مقيم كندز

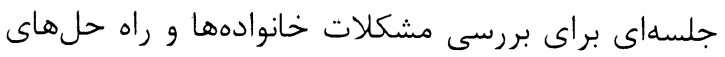

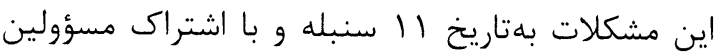
مؤسسات داخلى و خارجى در مقر دفتر ساحوى كندز

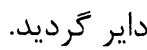

هدف از تدوير اين جلسه بيشتر حل مشكل زنان بيوه در

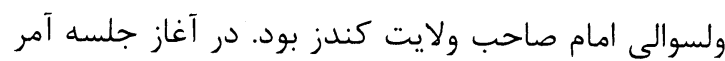
دفتر ساحوى كندز در رابطه به مشكلات و وضعيت زنان ولنان

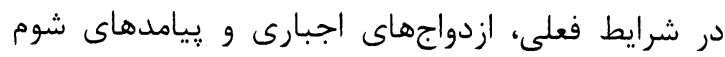


جمهورى آينده كشور و نمايندَان بِازلمان و شوراهاى محلى و آموزش مسائل حقوق بشرى بود در اين سمينار مسؤول بخش تعليم و تربيه در رابطه با نقش اعضاى كميسيون در تطبيق يروسه حقوق سياسي - مدنى اتباع

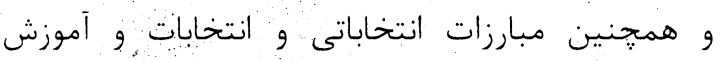
مسايل حقوق بشرى توضيحاتى ارائه بادند. سيس آمر بخش عدالت انتقالى پييرامون يروسه عدالت انتقالى و نهايى شدن پروسه مشوره ملى دز إفغانستان و

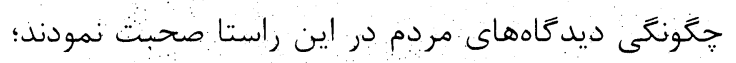

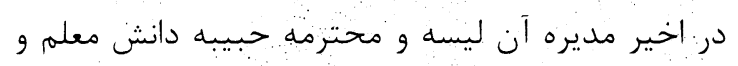
نماينده زنان در قانون اساسى كشور به نمايندگى از استادان و شاكردان در رابطه با ضرورت آموزش مسائل حقوق بشر نظريات خويش را مطرح نمودند و همجنان

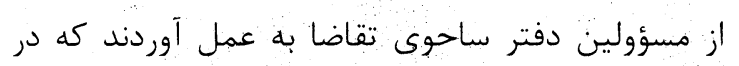
جهت بلند بردن سطح آگَاهى زنان دز مورد حقوق و مكلفيتهايشان، خشونت و و ازدواج هاى اجبارى؛

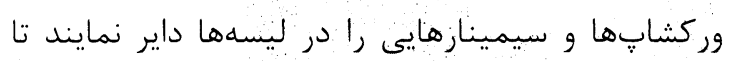
با استفاه از موضوعَاتى كه در وركشنابها ارائه مى ذهنيت اشتراك كنندگان روشن شود.

\section{حقوق سياسى و مدنى شهروندان}

به ابتكار آمريت تعليم و تربيه دفتر ساحوى كميسيون مستقل حقوق بشر افغانستان مقيم كندز و به همكارى دفتر ساحوى يوناما سيمينارى تحت عنوان(حمايت از حقوق سياسى- مدنى اتباع كشور درجريان مبارزات انتخاباتى) روز ينجشنبه / I سنبله در حالى كه معين

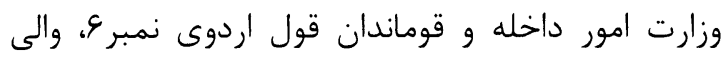
ولايت، رئيس امنيت ملى، رئيسه امور زنان، نمايندههاى احزاب سياسى، رئيس معارف، مسؤولين دفتر يوناما،
افغانستان، بخش حمايت از حقوق اطفال به منظور ايجاد

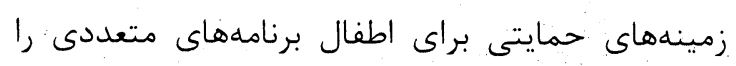
طرح و تطبيق نموده است كه اين برنامهها در برگيرندة بررسى وضعيت اطفال و تفكيك نيازمنذىهاى آنها در

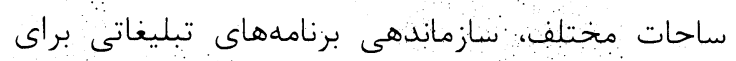

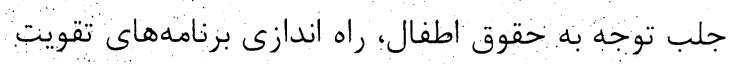
ظرفيتها و. بلند برذن سطح آكاهى آنها در رابطه به به به بهاه

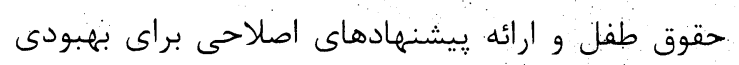
وضعيت اطفال در سرتاسر افغانستان مىباشد. يس از آن مسوول بخش حمايت از حقوق اطفال

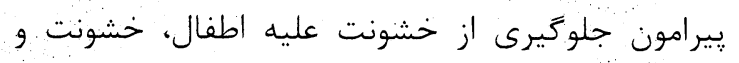
انواع و علل و انغيزههاى بلوجود آمدن توضيحات مفصلى ارائه نمودند و همڤنان بحثهاي آزاد درمورد

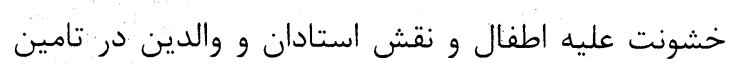
و اعاده حقوق طفل توسط شاملين محفل صورت گرفت. محفل با توزيع مجلات حقوق بشر و كتب مربوط به حقوق طفل و يوسترها و با آرزوى از بين رفتن خشونت عليه اطفال به پايان رسيد.

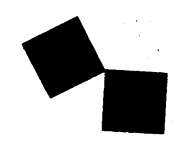

\section{حقوق بـشر، انتخابـات رياسـت جمهـورى و

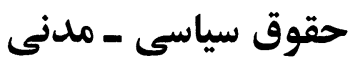
به تاريخ • r سنبله، سيمينارى تحت عنوان حقوق بـشر،

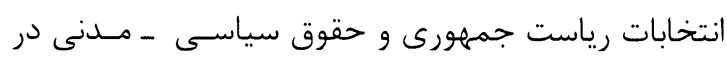

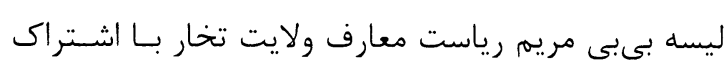

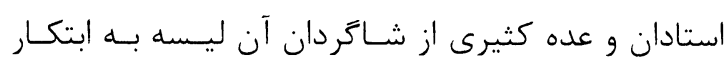
بخش تعليم و تربيه داير زرديد. هدف از تدوير اين سيمينار آكاهى زنان و دختران از نحوه برگزارى انتخابات و نقش زنان در انتخابات رياست 
حميداله نماينده احزاب سياسى، محترم سيد مير نماينده متنفذين محل، محترم آمر جنائى قوماندانى كندز و محترم سبحان قل نامول يكتن از شعراى كندز مضامين و مقالات خود را در رابطه به حمايت از حقوق مدنى سياسى در جريان انتخابات قرائت نمؤند و و همجنان آمر دفتر ساحوى كميسيون منتقل حقوق بشر افغانستان بر اجراى جهار حق و سه ״رنسيت در جريان يروسه انتخابات كه عبارت اند از حق آزادى بيان، حق سيرو سفر، حق آزادى انجمنها و حق آزادى اجتماعات و سه يرنسيڤٍ كه عبارتند از اصل عدم تبعيض، اصل عدم جانبدارى و اصل عدم تهديد تاكيد نموده و از مسؤولين دفتر مشترك كميسيون انتخابات تقاضا

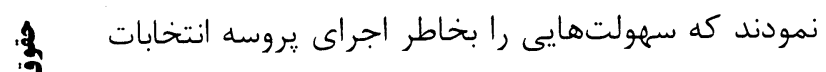
در زون شمالشرق فراهم سازند.

سيس رئيس كميسيون مشترك انتخاباتى در بخشى از سخنان خويش اظهار نمودند:اتا جايى كه به دفتر مشترك تنظيم انتخابات در زون شمالشرق مربوط است،

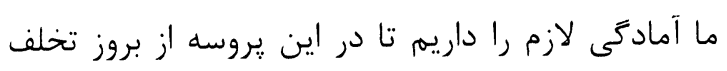

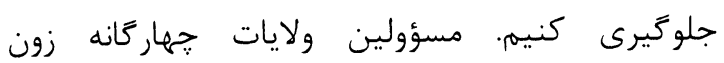
شمالشرق و قوماندانى هاى يوليس اين ولايات به كمك و همكارى اردوى ملى، يوليس ملى و قواى بين المللى به ما وعده سيرده اند تا زمينه را براى يكى انتخابات آزاد،

$$
\text { مستقيم و دموكراتيك فراهم نمايند. }
$$

اين سيمينار با صرف طعام و توزيع شماره سوم مجله حقوق بشر توسط مسؤول بخش مطبوعات به پايان رسيد.

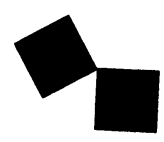

روساى انجوهاى داخلى و خارجى، نمايندههاى شوراى

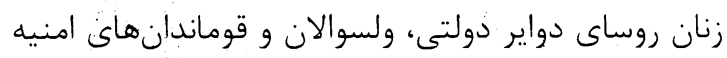

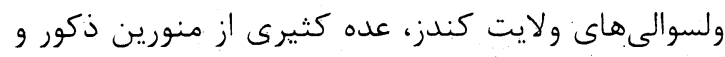

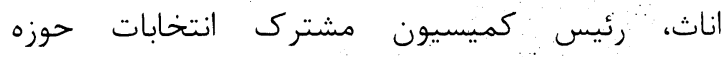
شمالشرق و كازمندان تيم نظارت :و بررسى از حقوق مقئيترن سياسى و مدنى دفتر ساحوى كميسيون مستقل حقوق بشر حضور داشتند، در تالار, كنفرانن هاى هوتل هون

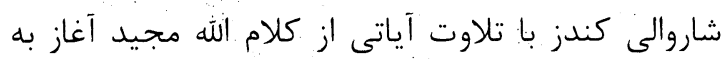

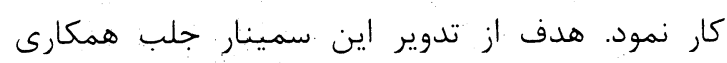
مسؤولين حراست از قانون در يروسه انتخابات بود تا زمينه مشاركت همه اقشار جامعه در يروسه انتخابات و ورئ حقوق سياسى مدنى به شكل دموكراتيك تامين گردد. در آغاز، معين وزارت امور داخله ضمن سياس و قدردانى از تدوير كنندگان اين سيمينار، كفتند: جاى بسا خوشى و مسرت است كه دفتر ساحوى كميسيون مستقل حقوق بشر افغانستان از همان آغاز كار خويش در ولايت كندز و ولايت همجوار، دست به يك سلسله فعاليتها و تدوير سيمينارهاي ارزنده زده اند و در راستاى روشن

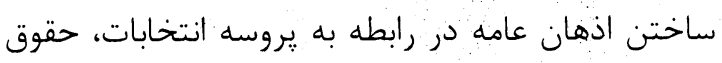
سياسى - مدنى و اسناد معتبر بينالمللى تلاشهاى موفقيت آميزى انجام داده است كه سيمينار امروزى نيز يكى از اين برنامههاى مفيد و سازنده مىباشد، من به نمايندگى از مسؤولين ملكى و نظامى براى دست اندركاران دفتر ساحوى حقوق بشر در كندز از خداوند بزرى موفقيت بيشتر را در اين زمينه آرزو مىكنم. به تعقيب آن سخنرانان به نوبت هر يك محترم والى ولايت كندز، محترم منير احمد نماينده دفتر يوناما، محترم شمسالدين حامدى آمر دفتر ساحوى، محترمه عفيفه انورى رئيسه امور زنان، محترم رئيس معارف، محترمه مسلمه والجى، محترمه ليلما فهيهم، محترمه مه فاطمه عزيزى، محترمه سيد بهالدين ايلغار، محترم 
ننكرهار ولايت د امنيه قوماندانى او د اجين د ولسوالى له نظارت خانو خخه ليدنه تر سره كره، د خيرنو به بهير

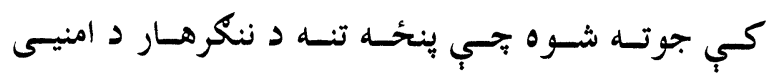

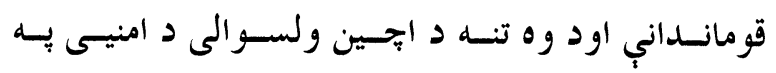

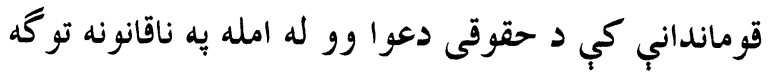

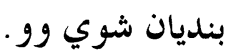

نومورى كسان د سيمه ييز دفتر د بلسوي يـه غوبنستنه او

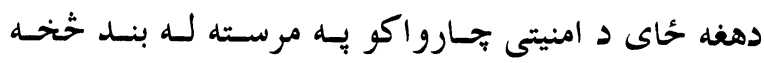

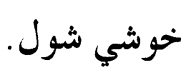$$
* * *
$$

\section{د وركشايونو جوريدل}

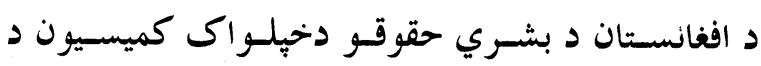
ختيخو ولايتونو د سيمه ييز دفتسر د بنسووني او روزنسي

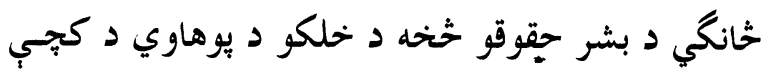

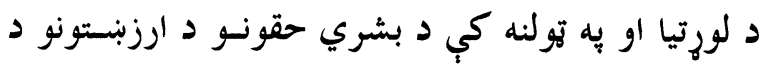

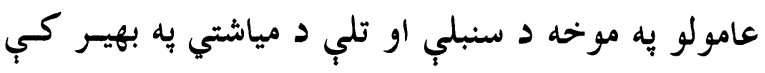

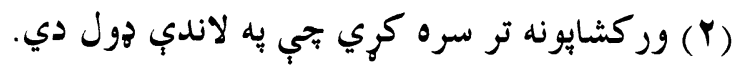

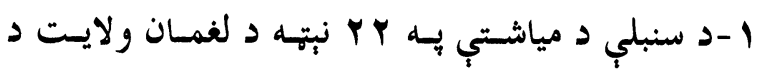

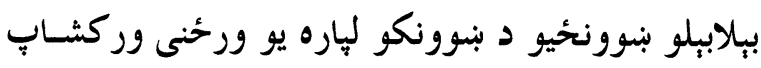

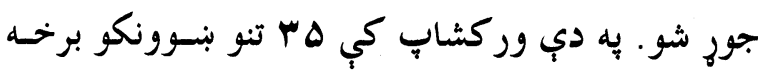

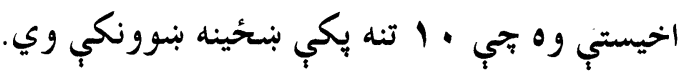

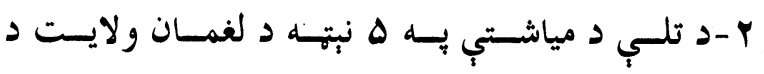

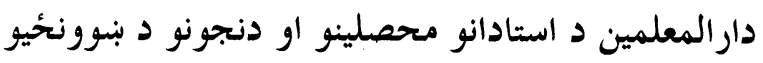

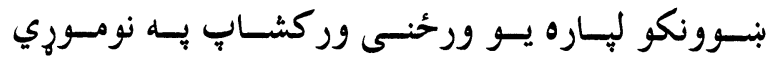

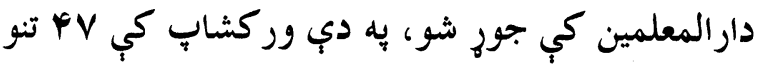

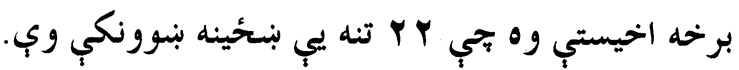
نوموريو وركشايونو كي برخوالو ته د بشر حقوقو مفهوم او تاريخحهه، اسـلام او د بشسر حقسوق، د بشـر حقوقـو

\section{جلال آباد} دره نور د بشري غميزى يه لومه كي دره نور د ننكرهار ولايت اروند يسوه ولسـوالي ده بجي

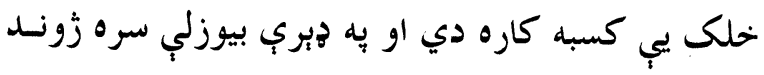

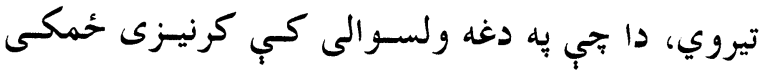

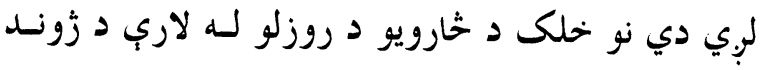
جارى برمخ بيايي.

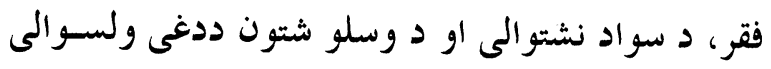

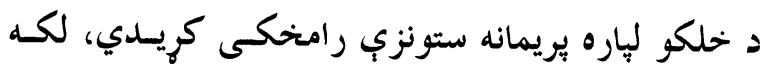
تجي د سنبلى د مياشتي به 19 إنيّه د اوبو دويسش بيرسر وسله واله نبنته وشوه تجي دهفب به بِايله كي يو بنسئه او دئه

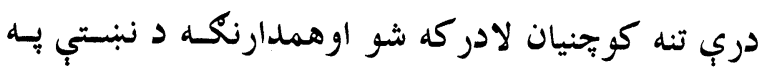
بهيسر كـي سـل كورونسه د خثسارويو سـره يسو حخساى

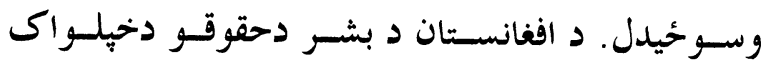

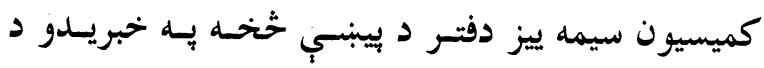

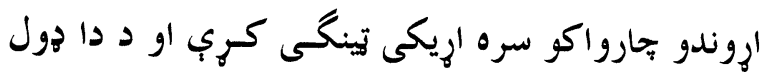

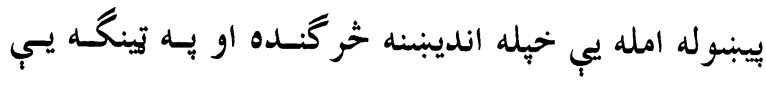

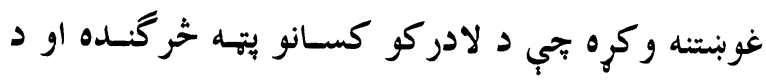

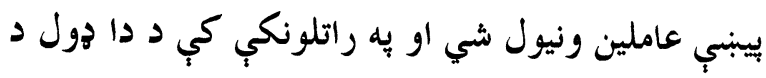

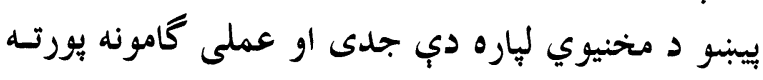

$$
* * *
$$$$
\text { شي. }
$$

\section{د بنديانو خلاصون}

اوه تنه بنديان د ننكرهـار د امنيسه قومـاداني او د اجسين ولسوالى له نظارت خحانو خخه خوشى شول. د ختيحو ولايتونو د بشري دحقوقو دخهيلواك كميسيون

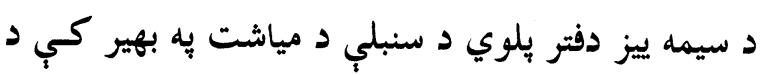


- دفقر ير ضد دي دولت كوندى هخي وكري او تولنيز خدمات دي خلكو ته به مساوي تو گه جممتو كراى شي. - كه يورتني مسوارد يـه يـام كي ونيسول شسي بنسايي بـهـ

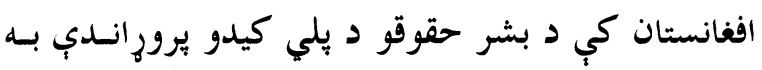
دبر خحنهونه له منحة لارشي.

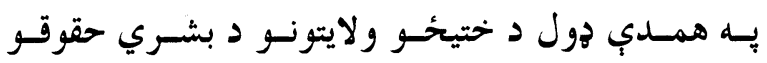
دخهلواك كميسيون سيمه ييز دفتر د كوجنيانو د حقوقو

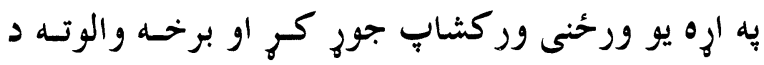

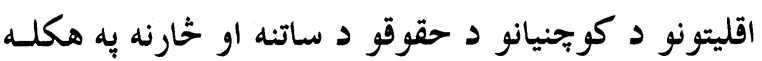

$$
\text { لازم معلومات وراندي شول. }
$$

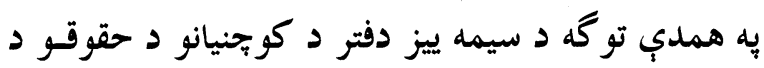

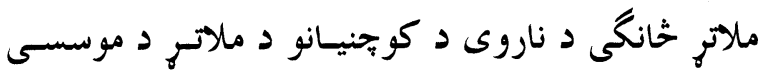

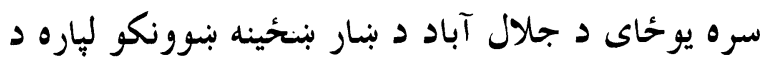

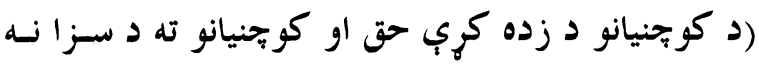
وركولو) يه نوم يو دوه ورحنب وركشابِ جور كر جهي

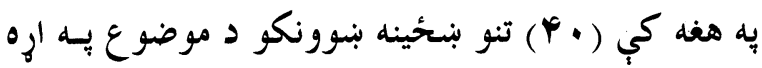
ارين بوهاوي ترلاسه كر. د يوبل ريوت له مخي د سيمه ييز دفتر د كوجنيانو

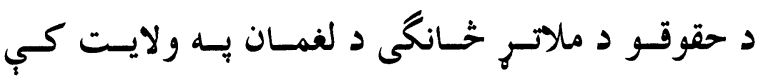
كوجنيانو د شاقه كارونو يه اره يوه خيرنه تر سره كـره.

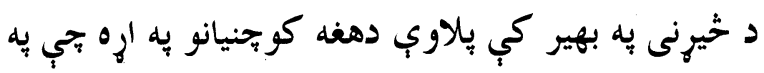

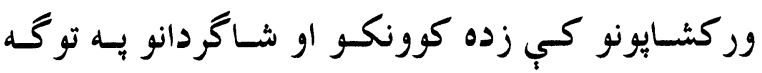
استخدام شوي، د كار د شرايطو جاج و اخيستلو او د د دون ور كشايونو خاوندان يجي وهخسول جـي لـه توانسه يورتسه

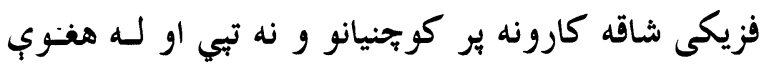

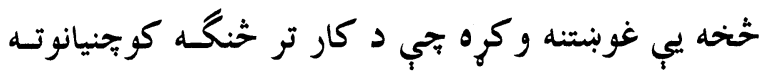
دا وخت وركري تجي يه بنسوونحئيو كي زده كروتسه هـم

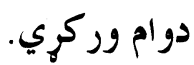

نزيو الـه اعلاميسه، د اتبـاعو سياسـي حقـوق، د انتقـالي عدالت مفهوم او د بلي كولو ببلاببلي جحاري خر خنده او

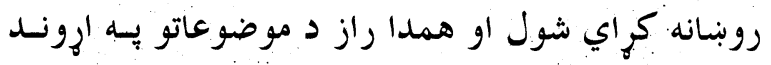
كروبي كارونه او ازاد بحثونه هم ترسره شول. د گروبي كارونو به ترخ كي برخو النو حينسي نظريسات

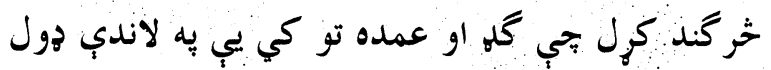
دي -د بى سبوادى يرضد دي بر اخه مبارزه وشي.

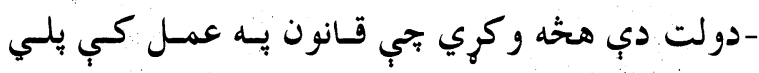
كري. - د بشر حقوقو خخه وخت بر وخت سبرغروني كيسبِي او سرغرونكي نسه مجسازات كيسبِي. بايسد دغسه كسـان مجازات كراب شي.

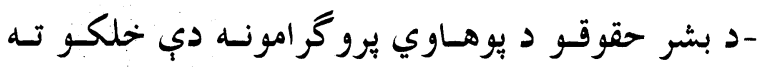

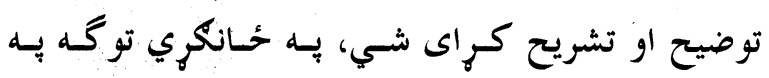
بنوونخيو كي بايد د مضمون به بنه تدريس شي.

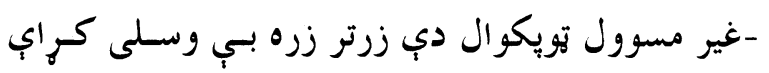
شي. - دولت دى د ملي اردو او ملي يوليسو به بياورتيسا كي

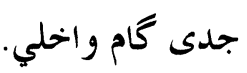

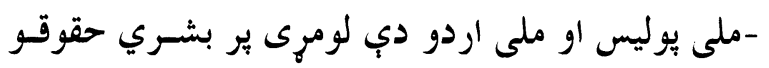

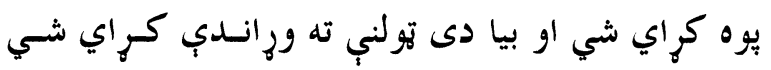
جي د خلكو امنيت خوندي كري.

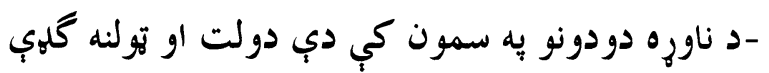

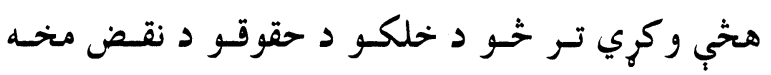

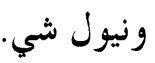
-هغه خوكى جي د كار اهل نسه وي بايسد برخساي يسي د

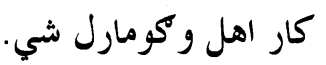


متههم و مجرم نيست، بلكه مشكل بزركتر در طى مراحل دوسيه ها و عدم رعايت حق و عدالت در صدور حكم و اعلام و ابلاغ جرم عليه مجرمين، توسط دستخاه هاى

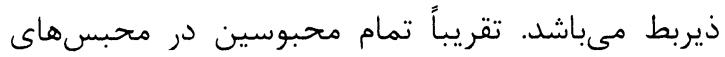

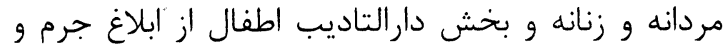

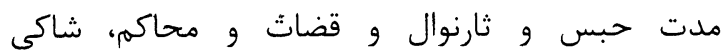

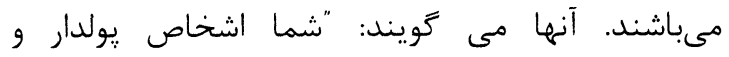
واسطهدار را در محبس نمى بينيد، زيرا آنها قبلاً به به بهات قضات رشوت داده و ذريعه واسطه ها، خود را از قيد حبس، آزاد ساخته اند، اينهايى كه در زندان باقى مانده

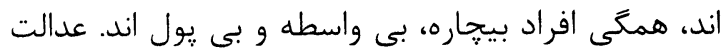
و انصاف و مروت وجود ندارد. عدالت در كيسه يولداران

مردان محبوسى را يافتيم كه يس از سه سال سيرى كردن حبس ، هنوز پارجه إبلاغشه را دريافت نكرده با وصف اين، دليل ثارنوال اينست كه گويا دوسيه در جريان و دورلن مىباشد. اين كه جه مرجع و يا جه له كسى ضامن فيصله دوسيه ها، در موقع مقرر مىباشد، "

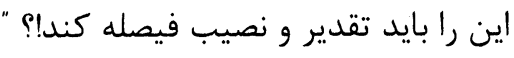
1) طفل ده سالهاى كه خودش نوع جرمش نمى داند، مدتى است، به قول خودش بدون تحقيق در

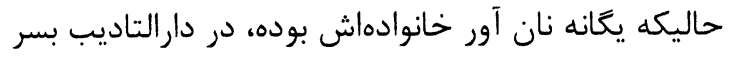
مىبرد. زنى در محبس زنانه گفت:" من به جرم زنا در اين جا شكنجه مىشوم ، در حالى كه طرف من من مدتها

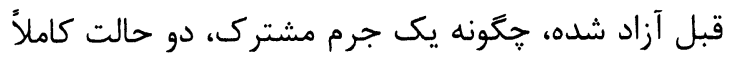
متفاوت دارد ؟) زن با عصبانيت فرياد كشيد: "ابه خدا قسم رشوت خورده اند، واسطه بازى جريان دارده در يك اتاق ديكر 1 الى 9 زن محبوس يك صدا لهد آمر جنائى

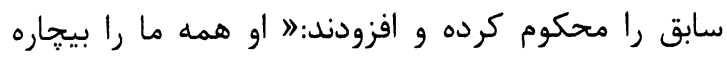

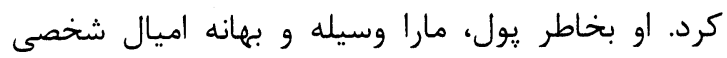

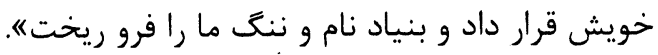

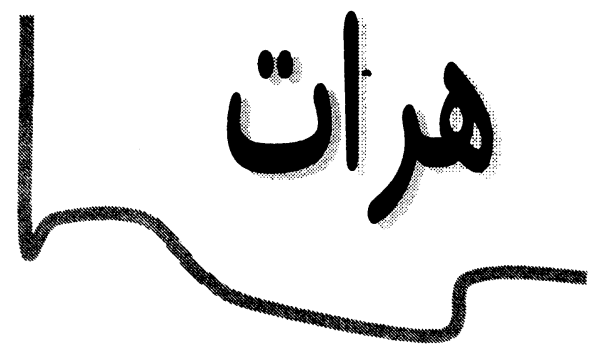

\section{يادداشتهايى از محبس هرات}

سرنوشت تاريك و آيندهى مبهمم، بد شانسى، فشار و

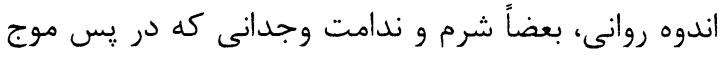
داد و فرياد و انكار از جرم خود و ملامت كردن ديكران

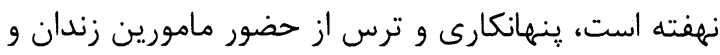
به ويزه يك حس نيرومند بد بينى عليه قاضى و ثارنوال

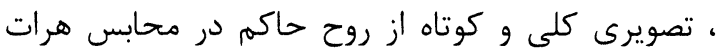

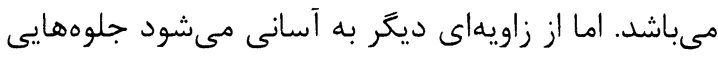
از روند بازسازى و نظافت را كه در محبس عمومى هرات

نيز سرزده است، مشاهده كرد. صنايع در رشته هاى فلزكارى ، حلبى سازى ، نجارى ، بوت دوزى ، قالين بافى ، خياطى و قنادى احيا

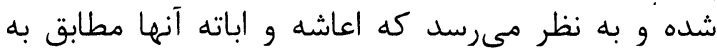
نورم هاى موجود وزارت عدليه ضمن داشتن حق پايواز، رعايت مىشود. كلينيك، آب، برق، تلويزيون محلى،

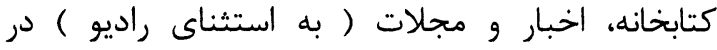
دسترس محبوسين قرار دارند؛ اما جارجوب مقررات رسيدگى به جرايم متهمين به ويزه طى مراحل دوسيه هاى نسبتى، متعلق به زمانهاى گذشته بوده و ايجاب

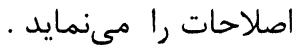
مشكل تنها در فقدان يك تكنالوزى پيشرفته كريمينال تخنيك مامورين جنائى، ميتود جرم شناسى و اقامه شهود، اسناد و علايم و مدارك شفاف جرمى عليه 
كه به نظر شما فكر مى كنيد در عقب ماجراى دستخيرى شما مسأله قومى نهفته باشد يا خير؟ حرف دقيق و روشنى نغفت؛ اما افزود: اهنگامى كه مرا به زندان آوردند، هر سه فرزند مرا يكى يى ديخرى كه به ديدن و به قصد خبر زيرى از من آمده بودند، دستخير كرده و ورئي اكنون هر سه فرزند جوان من نيز در توقيف بسر

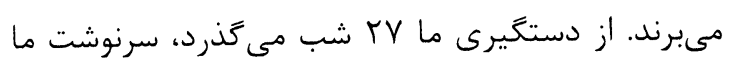
نامعلوم است. اما مدير محبس و صنايع هرات، طور ديخرى به

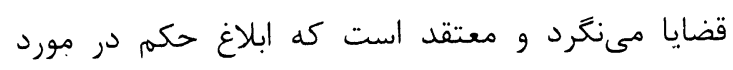
مدت حبس و جزاى محبوسين تا حدود زيادى عادلانه است. وى از يك سيستمم تماس دائمى با محبوسين خبر

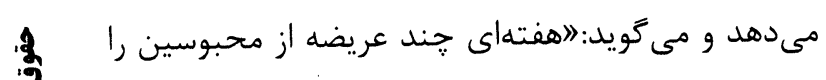

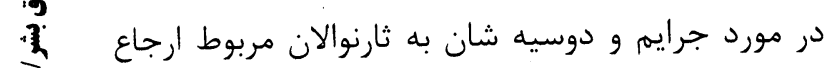

مى كنيم و درخصوص كسب قناعت محبوسين تلاش مى كنيم". مدير محبس هرات، قضيه رشوه ستانى و ساير انواع بيروكراسى در هنگًام صدور حكم جزاها را رد مى كند و تاكيد دارد" كه هيجزَّنه كوته قفلى و زولانه وجود ندارد و همزمان با يُيروزى حدود سه سال قبل، تمام سلولهاى انفرادى را تخريب كرده اند. وى در عوض، ييشنهاد ساختمان يك سالون بزرگتر ملاقات، براى محبوسين از وزارت عدليه را دارد. وى مىافزايد: در

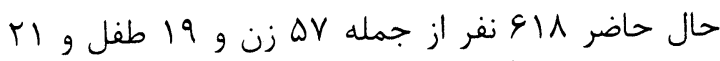
اسير جنگى در اين محبس مدت محكوميت حبس شانرا سيرى مى كنند. وى در محل كارش يك بسته نسبتاً بزرگ از بسته هاى كوجٍى مواد مخدره مانند ، جرس، ترياك و هيروئين را نشان داد و افزود: \ ما عدهاى از متهمين را كه تحت تاثير مواد نشه اى، دست به ارتكاب انواع جرايم زده اند و يا معتاد بوده اند، محبوس كرده و با جدا كردن آنها از مواد زهرناك
از ميان آنها زن ·f سالهاى كه سه طفل خورد سن داشت با گريه و التماس مى گفت: ينج طفل به شمول دو دختر جوان و تنها يك يسر זا ساله در خانه دارم كه تا صبح از ترس بيدارند و مىلرزند. مرا از روى لرى سرك گرفتند. آيا من با اين سرو وضع و با اين سن و اين قدر طفل و كودى اهل جنين عمل زشتى هستم؟ شوهرم به ايران گريخت و كسى. ندارم كه از من و اولاد هايم خبر بخيرد.《 او را با گريه و اشك و اندوه هايش تنها گذاشته و به سراغ ثارنوال كه بهخاطر رسيدگى به جرايم محبوسين با ما آمده بود، رفتم. ثارنوال تاكيد كرد كه فعل زنا بر اين زن كه دوسيه اش از طريق جنائى آمده است، تثبيت گرديده و وى مجرم است. زن جوان ديخرى به همين اتهام، با عجز و زارى از ما خواست كه اقلاً به يدرش ماجراى حبس ويرا اطلاع دهيه، زيرا هيجكس از خانواده او نمىدانند كه او اكنون زندانى است. با اين حال زنان محبوس از طرز بود و باش و آب و نان و برق شكايتى ندارند. برخى از آنها به عبادات شبانه مىيردازند و در يك سالون بزرگتر خياطى مىنمايند.

ياس و نكرانى در همه جا سايه افخَنده و حقايق در يس يرده حدسيات گَنَ و اتهامات ناروشن، ينهان شده اند. به همين دليل اكثر متهمين و مجرمين خواهان تجديد نظر كلى بر دوسيه هاى شان مىباشند. در بخش محبوسين سياسى مىتوان از اسيران جنگى حادثه دوم حمل، اY محبوس از افراد جنرال ظاهر نايب زاده قوماندان سابق فرقه VIV هرات نام برد. آنها با صراحت بر بيگناهى خود تاكيد دارند؛ اما بايد توجه داشت كه مطالعه و قضاوت يك جانبه نيز به ساده انديشى مى انجامد. ما جُگونگى حقيقت ماجرا را در رياست امنيت ملى ييخيرى نكرديم. اما وقتى از حاجى ... يرسيده شد 
حقوق بشر دفتر ساحوى هرات اظهار قدردانى نموده و

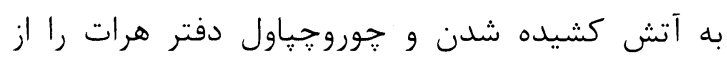
طرف يك مشت عناصر اوباش و بى كفايت محكوم نمود.

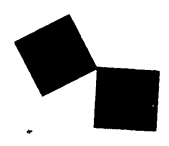

\section{حقوق بشر، دمو كر اسى و انتخابات}

سازمان حقوق بشر و حفظ محيط زيست افغانستان به تاريخ ها ميزان سال روان سيمينار يك روزه اى رات تحت عنوان (توضيح حقوق بشر، دموكراسى و انتخابات) در تالار رستورانت بهارستان واقع در باغ ملت شهر هرات

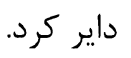

درين سيمينار علاوه بر مسئول دفتر ساحوى كميسيون مستقل حقوق بشر افغانستان در هرات، معاون والى، نمايندگان احزاب سياسى، نهادهاى مدنى، كميسيون مشترك تنظيم انتخابات و تعدادى از كارمندان ساير ادارات و موسسات دولتى و غيردولتى نيز اشتراك ورزيده بودند. اين گردهمايى با تلاوت آياتى از كلام روحيرور الهیى و بيانيه مسوول دفتر ساحوى كميسيون رسما افتتاح گرديد. وى ضمن معرفى كميسيون و جَّونكَى ايجاد آن و همجنين اجرآت و و فعاليت مستقلانه، شفاف و واقعبينانه ى كميسيون صحبت نموده و گَفت: كميسيون منحيث يك نهاد مستقل، هميشه و بدون هرگونه تبعيض و تمايز به انسان، انسانيت و ارزش هاى انسانى انديشيده و عليه ظلم، بى عدالتى و قانون شكنى با قاطعيت مبارزه مى نمايد. وى در ادامه سخنانش ضمن حمايت از تدوير همجو محافل و زردهمايى هايى وعده هرگونه همكارى با سازمان مذكور را ابراز نمود. به دنبال آن معاون مقام محترم
مخدره، زير نظر داكتوران معالج و مشورههاى سالم، به ترك اعتياد آنها موفق مىشويمم و آنها را منحيث افراد سالم، تجديد تربيت يافته و صاحب مهارتهاى حرفهاى به جامعه باز مى حرف اخير مدير محبس و صنايع هرات اينست كه به محبس يك مدرسه زندگى و. كانون تجديد تربيت و داراى نظم و مقررات خاص خود است. وى اميدوار است كه با تصويب قانون اساسى جديد كشور و تعميم حقوق و آزاديهاى اتباع، هموطنان به قوانين اتكا و تاسى جسته و با قوانين در تضاد واقع نشوند و اسباب ارتكاب به جرايم را فراهم نساخته و در نتيجه امنيت، آسايش و نظم ملى را برهم نزنند و در مقام يك عضو فعال و مثبت جامعه در يروسه توسعه و بازسازى براى خود و جامعه خود مفيد واقع ₹ردند.

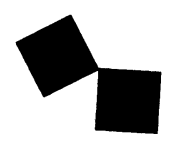

\section{آموزش حقوق بشر در انجيل} جلسه ى آموزش حقوق بشر به ابتكار دفتر ساحوى كميسيون مستقل حقوق بشر در ليسه رواشان ولسوالى انجيل با اشتراك 9 نفر از معلمين اناث مكتب و 11 نفر زن از زنان منور قريه جات همجوار كه در ايران درس خوانده بودند، داير زرديد و موضوعات زير از طرف بخش تعليم و تربيه كميسيون ارائه گرديد: وظايف و صلاحيت هاى كميسيون مستقل حقوق بشر افغانستان، برشمردن بعضى از حقوق و وجايب اتباع كشور در يرتو اعلاميه جهانى حقوق بشروضرورت و ايجاد كميسيون در جامعه افغانى طبق خواست دولت فعلى افغانستان. در اخير جلسه، سر معلم مكتب مذكور از كميسيون مستقل 


\section{كنمهار}

ولايت مسوول ولايتى حزب ملى افغانستان و نماينده كميسيون مشترك تنظيم انتخابات در رابطه به موضوع

د ماشومانو تبنتونه د اندينني ورده

د روان كـال دوبِي د مياشستى يـه ا انيتهـه يسوه ذولسه د

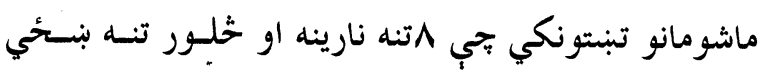
وى او حانونه يب اصلا د باكستان اتباع بلل يوه ماشومه نجلى د كندهار د رنله د ولسوالي خخه تبنتوي تجي لـه نيكمرغه د كندهار د بيوليسو له خوا لاس به لاس نيسول

كَبְ.ي.

له كومه خحايه تجي تبنتونكى لاس بـلاس نيسول شسوي او يخيل جرم يب اعتراف كري د بشر د حقوقو سـيمه ييز دفتر د قانون د مجريانو خخه غوبنتنه كوي تجي د بشـر د حقوقو به يام كب نيولو سره موضسوع قـانوني وخيـرل شي او مجرمين د قانونِ يه رنا كي بخخيله سزا ورسسيوي او هم يب به سهيل لويديحسه حسوزه كي د ماشسومانو د

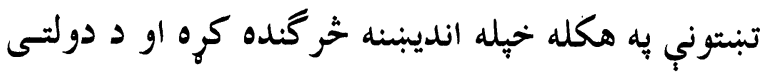
مسؤولو و بحارواكو خخه يب به كلكه غوبنتنه وكره تي د ماشومانود تبنتوني د مخنبوى به هكله رغنده او بحتبك كامونه بورته كري.

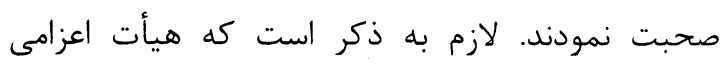
سازمان حقوق بشر و حفظ محيط زيست افغانستان به

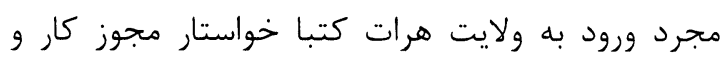
فعاليت آن سازمان در ولايت هرات گرديد كه رياست

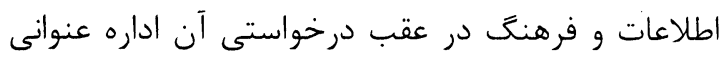
دفتر ساحوى كميسيون جنين نعاشته است: در صورت

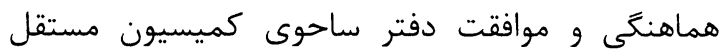
حقوق بشر افغانستان در هرات هيج. تونه مانعى در بيشبرد فعاليت تان وجود ندارد

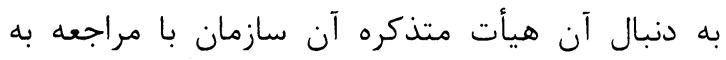

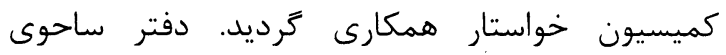
كميسيون موافقت خويش را كتبا بدين شرح بيان نمود:

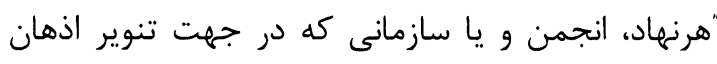
عامه مطابق به ارزش هاى ملى و بين المللى و رعايت كامل قوانين و مقررات كشور كار و فعاليت بنمايد، كميسيون مستقل حقوق بشر افغانستان همجرو فعاليت

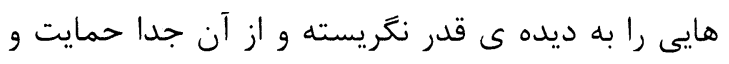
يشتيبانى مى نمايد. 


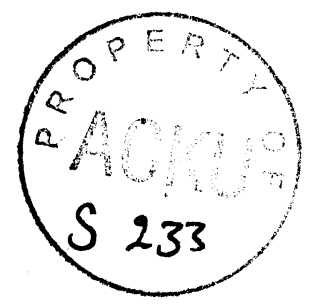

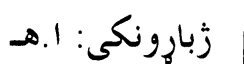

جي ذير مخته د شين ملاويشتونى (كمربند) بيه نوم ديسو

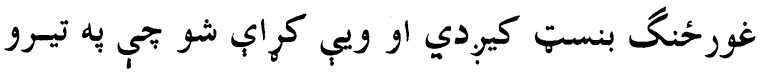
دير شو كلونو كي د غريبو ميرمنو به زيار ديرش مليونسه

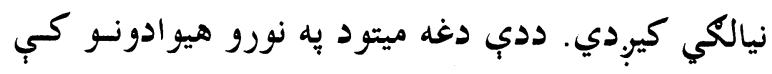

$$
\text { هم منلى شويدى. }
$$

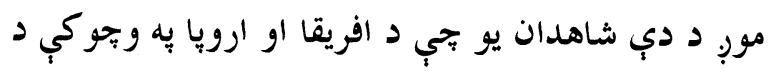

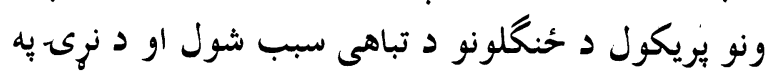
هيرو سيمو كي د و بحو دبنتو سبب و گرحيدل. د محيكى

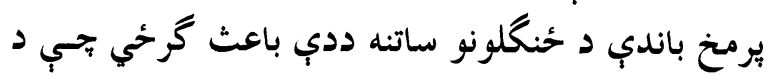

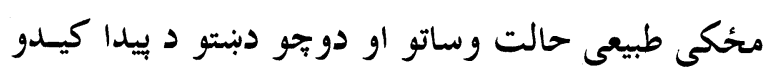

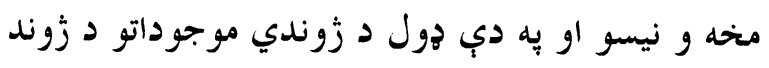

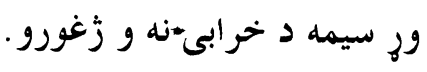

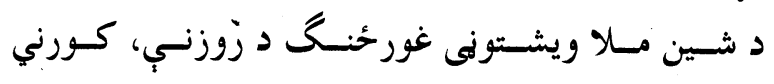

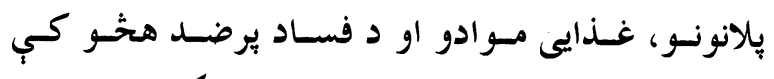

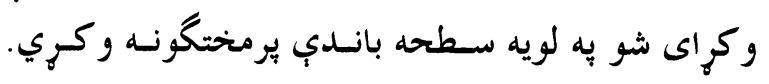

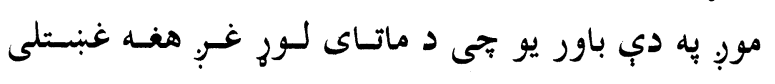

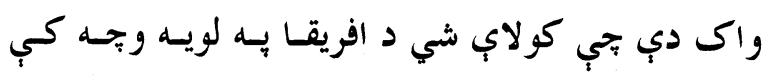

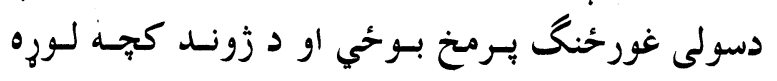

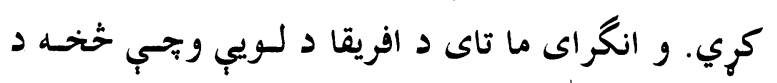

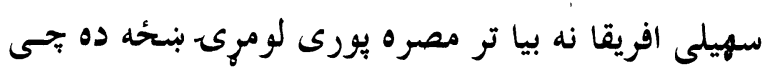
د نوبل جايزه ترلاسه كوي. دا د تولو افريقايسانو د يـاره

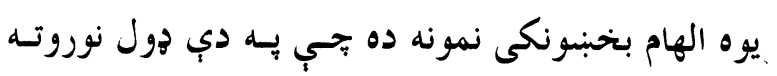

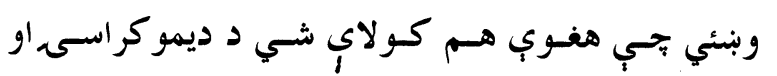
يرمختخ دياره مبارزه و كري هئي
د ناروى د نوبل كميتب يريكره كريده تجي د سولى لِاره

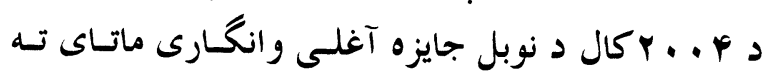
وركري، دغي ميرمنسى د ديموكراسسى او سـولى ديساره سترى هلى، حُلى كريدي.

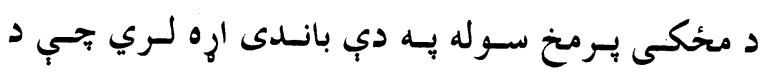

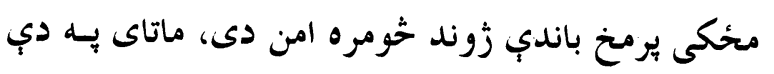
هخه كي ده بحي د زوندي موجوداتو د ساتنى ديساره يسه كينيا او توله افريقا كي د اقتصسادي، فرهنكي او ويساكى هوا د ساتلو د بياره زيار وباسى تر خو زوند يه امن كن كي وي. دغي آغلى يه يوه مقدس كار لاس بـورى كريسدى

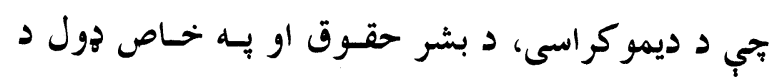

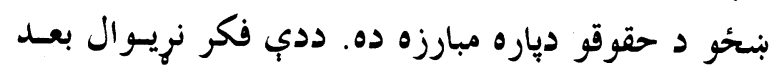
لري خو فعاليت يب سيمه ايز دى. ماتاى به ذيره زرورتيا سره د كينيا د بخو اني ظالم رزيسم به مقابل كي دريدلى ده. دغي مبارزى ميرمنى به خـاص

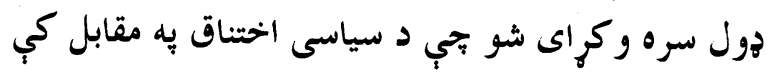

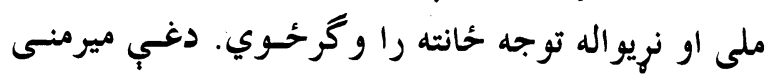

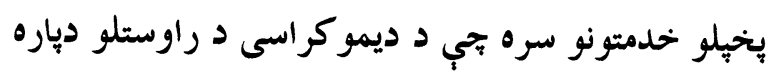

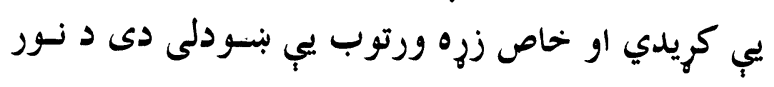

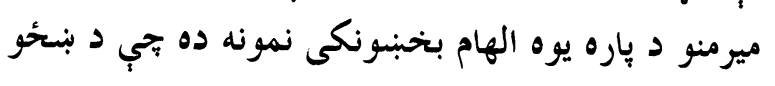
د زوندانه د بنه كولو د باره فعاليت كوي.

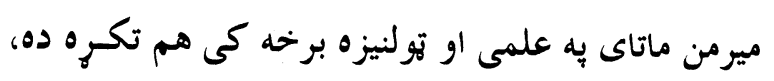

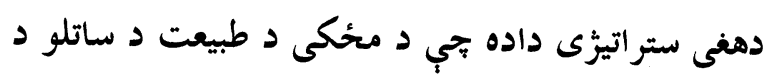

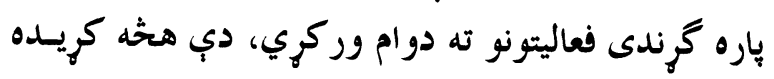




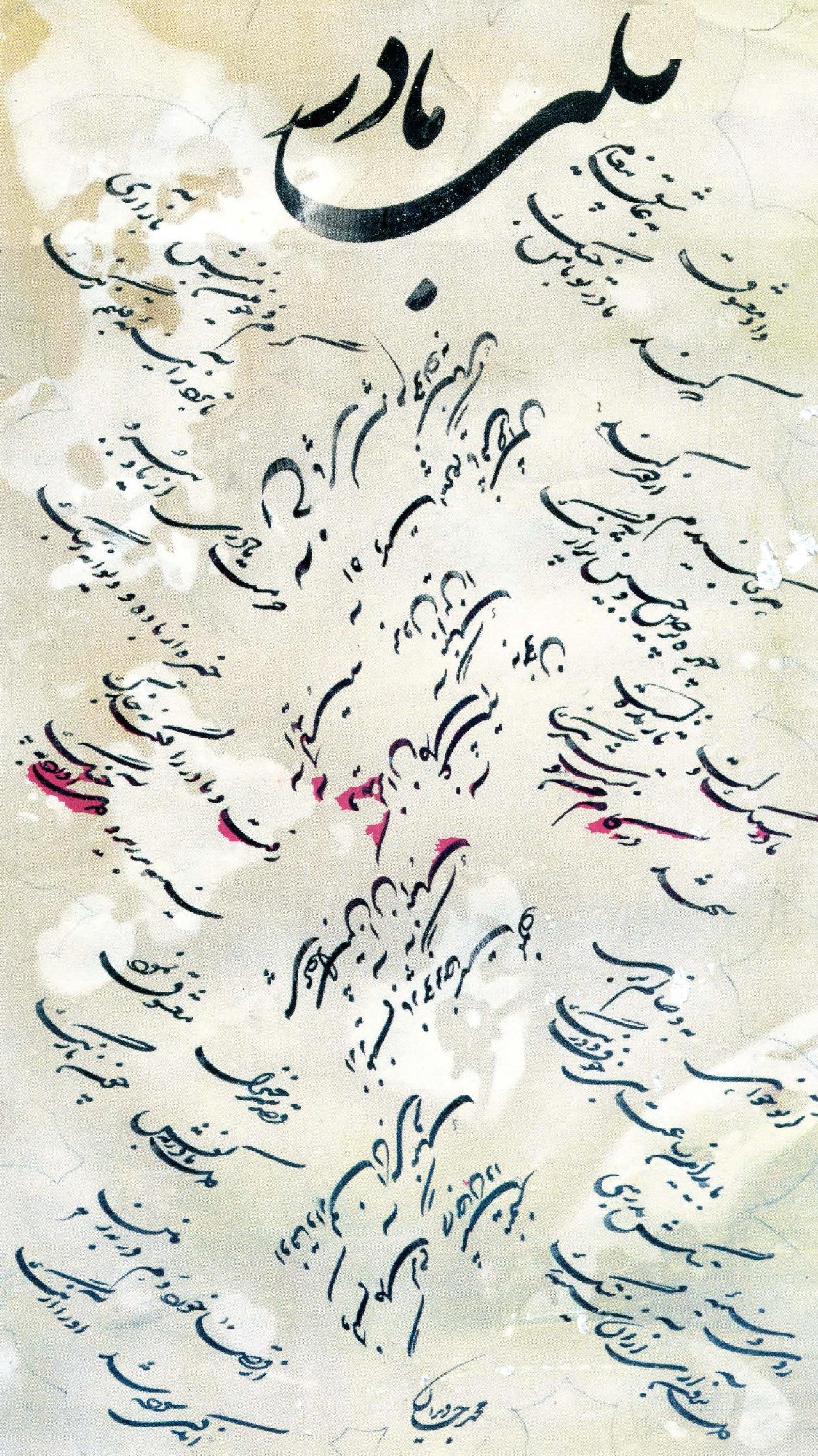




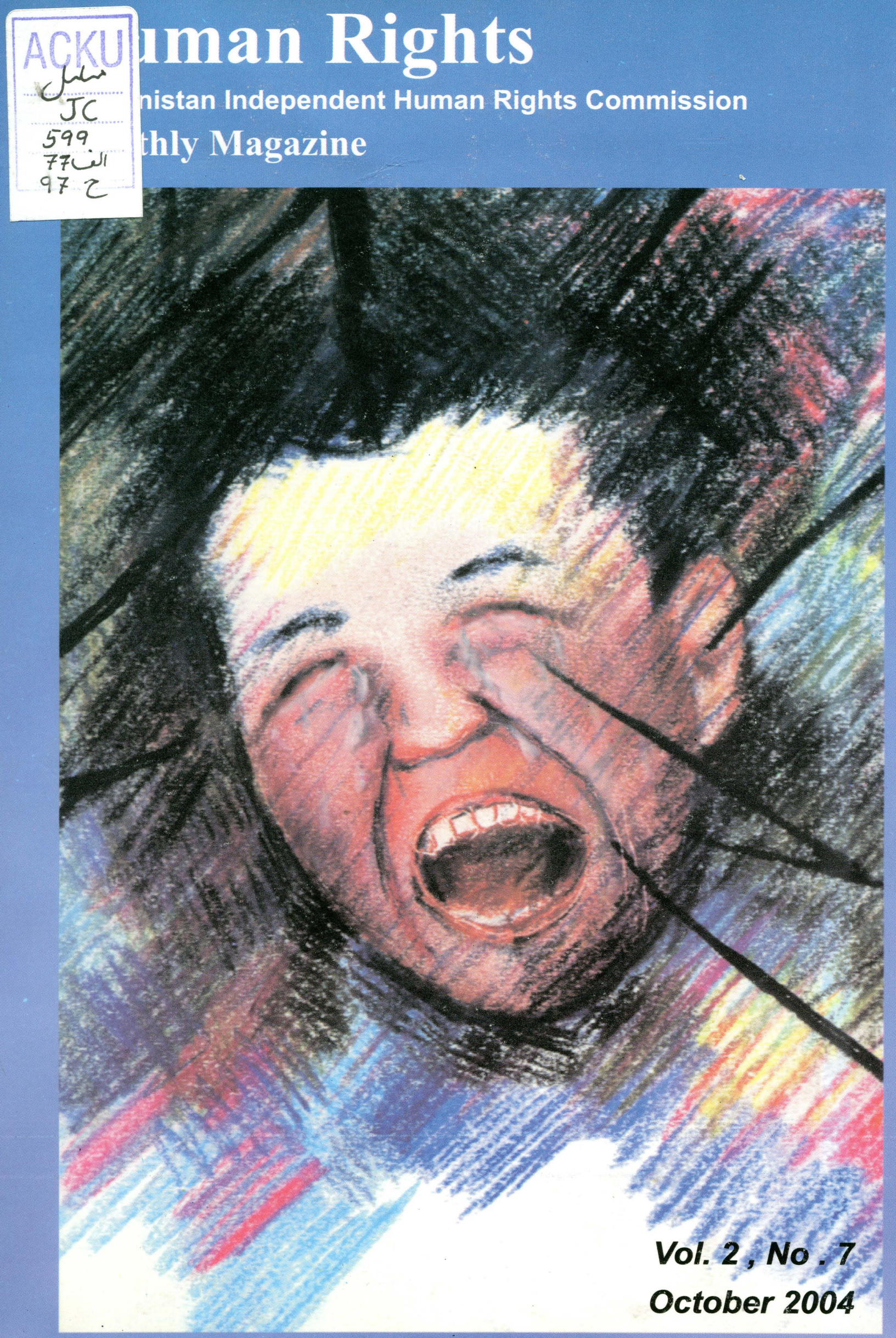

